
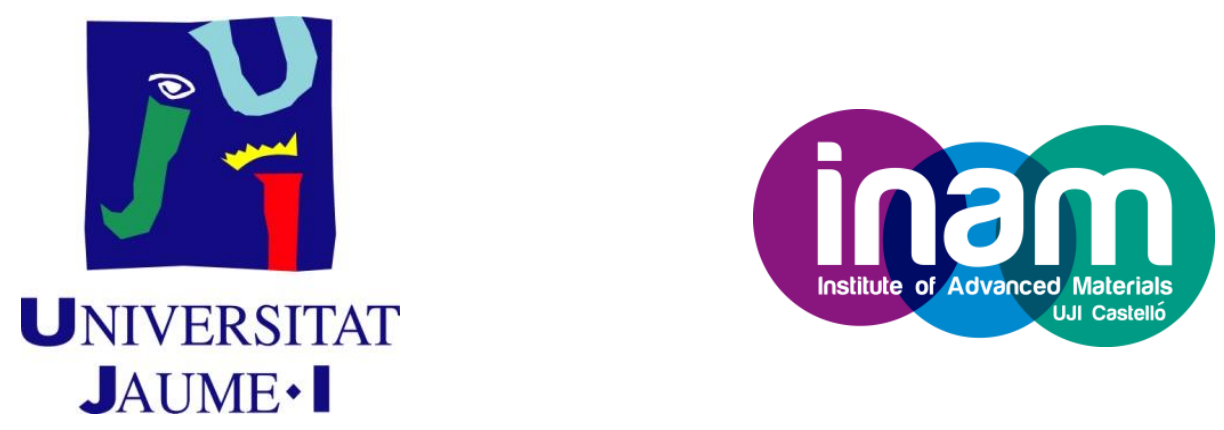

UNIVERSITAT JAUME I

Departamento de Química Inorgánica y Orgánica

Institute of Advanced Materials

\title{
Poly-N-Heterocyclic Carbene Ligands with Rigid Polyaromatic Linkers. Self-Assembly and Host-Guest Chemistry
}

Doctoral Thesis

Carmen Mejuto Nieblas

PhD. Supervisors: Eduardo Peris and Gregorio Guisado-Barrios Castellón de la Plana, June 2017 

Prof. Dr. Eduardo Peris Fajarnés, Catedrático de Química Inorgánica y Dr. Gregorio Guisado Barrios, Investigador Postdoctoral Juan de la Cierva de la Universitat Jaume I, pertenecientes al Departamento de Química Inorgánica y Orgánica de la Univesitat Jaume I

Certifican: Que la Tesis Doctoral con el título "Poly N-Heterocyclic Carbene Ligands with Rigid Polyaromatic Linkers. Self-Assembly and Host-Guest Chemistry" ha sido desarollada bajo su dirección, en el Departamento de Química Inorgánica y Orgánica de la Universitat Jaume I, por Carmen Mejuto Nieblas

Castellón de la Plana, Junio de 2017

Fdo. Prof. Dr. Eduardo Peris Fajarnés Fdo. Dr. Gregorio Guisado Barrios 



\section{Acknowledgements /Agradecimientos}

Creo que esta es la parte más difícil de la tesis...intentar expresar y hacer llegar a la gente, lo que han sido para mí estos últimos años, (nota: soy del norte y me cuesta expresar mis sentimientos...) pero...vamos allá...

Gracias a mis directores de tesis Eduardo y Goyo por darme la oportunidad de hacer realidad un sueño y confiar en mí desde el primer momento. Gracias a Eduardo por valorarme, acogerme, aguantarme, enseñarme, entenderme y sobre todo por tu santa paciencia hacia mi persona. Tu grupo es como una gran familia y desde el primer momento me habéis hecho sentir como en casa.

Gracias a Maca por ser la mami de esta familia y estar siempre pendiente de todos, tanto profesional como personalmente...no sé qué haríamos sin ti!!!...y a José Mata por tu alegría y siempre tener una sonrisa en la cara.

Gracias a todos mis compañeros:

Los que ya son doctores, Susana, Elena, Cande, Sergio (te he echado mucho de menos), Sara, Hugo y Sheila (desde el principio a fin...trabajo, viajes, congresos, bailes, buenos y malos momentos, pero sobre todo gracias por llevarme a tu casa y hacerme sentir el calor de hogar).

Los que han estado sólo por un tiempo, a George y Tobías especialmente.

Los que aún perduran, mis pequeños niños Víctor y David, a Chiara, Alba, Mapi (te estás adaptando a la perfección, jajaja), Pollito (casi igual de mala leche que yo...y aunque se comentaba que seríamos una mezcla explosiva...ya ves...al final en nuestro mundo nos entendemos...eres todo un descubrimiento de persona) y por último y no por ello menos importante...GRACIAS a Daniel Nuevo Vialás ("yo también te quiero y...yo tampoco jamás me casaría contigo", gracias por tu calma y paciencia, eres una de las mejores personas que me he cruzado en la vida)

$\mathrm{Y}$ al resto de mis compañeros de la UJI, profesores, compañeros y alumnos...al final entre cenas de departamentos y eventos socio-culturales varios, parece que lleve aquí toda la vida...

A los técnicos: Silvia, Pedra, Cristian y Gabriel... sois grandes chicos!

A todos los profesores de los cuales he recibido algún tipo de ayuda, ya sea por una colaboración (Prof. Pau Ballester) o realización de cálculos teóricos (Prof. Dmitri Gusev). Pero sobre todo a Beatriz Royo, por haberme dado la oportunidad de realizar una estancia en su grupo de investigación.

Tampoco puedo olvidarme de toda la gente que me ayudó a ser feliz durante los cuatro meses vividos en Oeiras, Aida, Cristiana, Rita, Ana, Naiara, Arturo y Filipe. 
Gracias a toda la gente de la Universidad de Oviedo, Lau (cinco años de carrera, cinco años de risas y buenos momentos), Egüen (mil momentos, moñas, fútbol, risas y homenajes...échote de menos), Marina (me encanta lo loca que estas! Eres una crack!), Lucí (gracias por tu paciencia, por estar ahí en mis malos día, por no apagarme la música reguetonera a pesar de los sarpullidos que te generaba y como dices tú...por enseñarme todo lo que sé!jajaja), Julien (eres mi medio limón...eso lo resume todo...) y a toda la gente de los laboratorios de la tercera planta, ha sido un placer trabajar a vuestro lado!

Gracias a Xavi porque probablemente sin ti no hubiera conseguido ni acabar la carrera ni haber llegado a donde estoy...siempre te agradeceré el haber dejado marchar...

Gracias a mis amig@s de la infancia, Shei, Lau, Talia, Vane, Leti, Silvia, Sara, Almu y Julián ha sido un placer crecer a vuestro lado.

A la gente que tengo lejos, pero es como si tuviera a mi lado cada día, Abel ("pecar es humano, pero sabe divino") y Sarita (GRACIAS por lo vivido y lo que nos queda por vivir) os quiero y necesito chicos.

A la toda la gente de Castellón que se ha cruzado en mi vida, ya sea de día o de noche...mis "Dignas on fire", residentes en Miami (R.A), gente de Alcora y demás pueblos de la contorná...pero sobre todo a Gimeno (por tus abrazos donde sobran las palabras), a Ana Mor (por siempre estar dispuesta al cotarrito y un "jaguercito", haces que la vida sea más facíl!!) y Maite (ains mi reina mora mía, somos la noche y el día, polos opuestos, el yin y el yang...pero tenerte cerca me alegra la vida, me aportas confianza, cariño y positividad, gracias por siempre estar sonriendo, por los buenos momentos pero también gracias por los días de sofá, de los que probablemente hayamos aprendido ambas) os quiero!!!

A Júlia por su inocencia y por ser la alegría de la casa...no sabía lo dulces y enérgicos que pueden ser tus despertares...

Y qué decirle a mi Alcorino...?? gracias por completarme como persona, por despertar un lado de mí que ni yo conocía y sobre todo por darme paz, eres todo lo que necesito...

Gracias a toda mi familia, abuelos, tíos, primos (y también amigos), pero sobre todo a mis padres por quererme bajo cualquier circunstancia.

Gracias a todo el mundo por convertir un sueño en realidad! 


Nomenclature iv

List of Abbreviations iv

Presentación de la memoria vii

Chapter 1

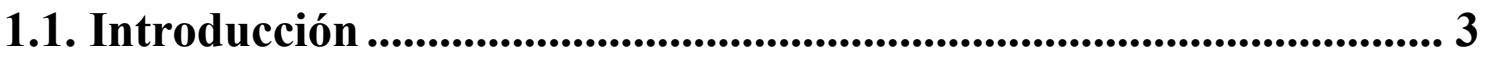

1.1.1. Sistemas poliaromáticos funcionalizados con ligandos $\mathrm{NHC} \mathrm{...........................} 3$

1.1.2. Reacciones de autoensamblaje (Self-Assembly) .............................................. 6

1.1.3. Complejos de coordinación supramoleculares $(S C C s)$.................................... 8

1.1.4. Antecedentes en nuestro grupo de investigación: Química Organometálica y

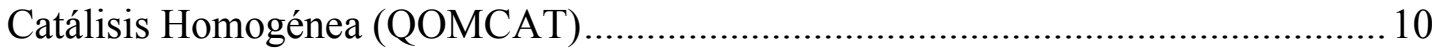

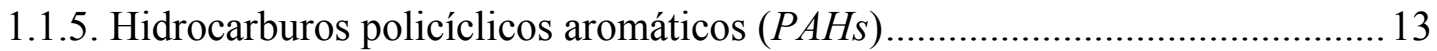

1.1.6. Química Host-Guest y receptores supramoleculares .................................... 15

1.1.6.1. Receptores moleculares para la separación de fulerenos ...................... 16

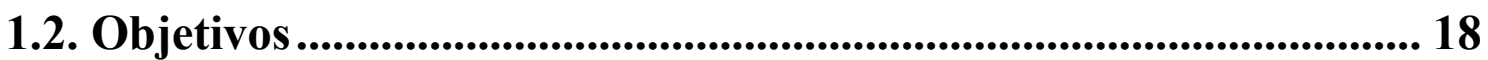

1.3. Referencias ................................................................................................. 19

\section{Chapter 2}

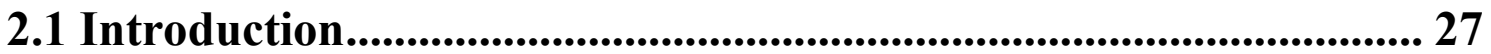

2.2 Results and discussion ........................................................................ 28

2.2.1 Synthesis and characterization of $C_{3}$-symmetry tris-azolium salts .................. 28

2.2.1.1 $C_{3}$-symmetry tris-imidazolium salts. Synthesis and characterization .....29

2.2.1.2 $C_{3}$-symmetry tris-triazolium salt. Synthesis and characterization .......... 31

2.2.2 Luminescence properties of tris-imidazolium salts......................................... 32

2.2.3 Synthesis and characterization of the tri-metallic complexes .......................... 33

2.2.3.1 Iridium(I) and rhodium(I) complexes ............................................... 34

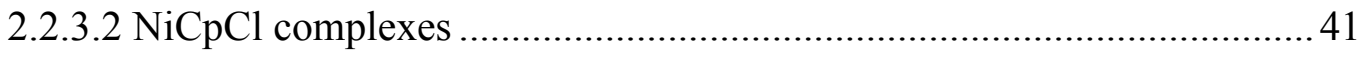

2.2.4 Electronic properties of tri- $v s$. mono-metallic complexes ............................. 42

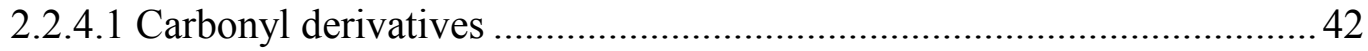

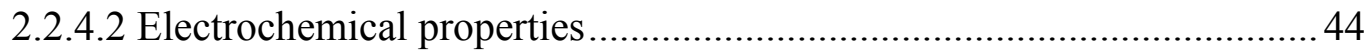


2.2.5.1 Catalytic activity of the trimetallic rhodium complexes: 1,4-Addition of Arylboronic Acids to Cyclohex-2-one

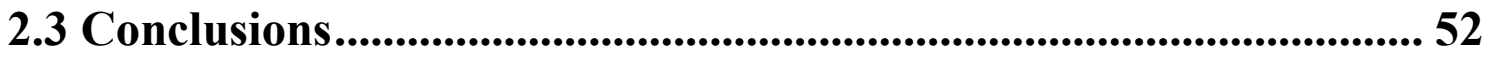

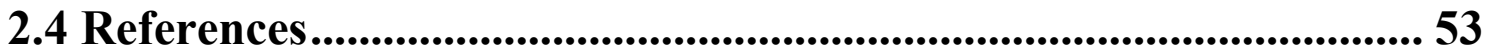

\section{Chapter 3}

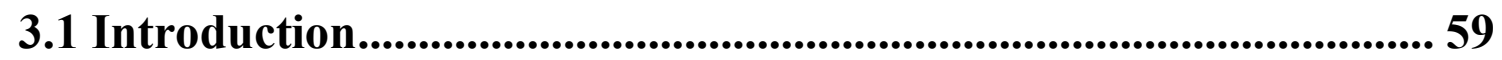

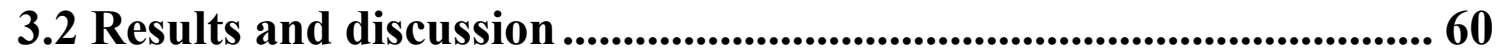

3.2.1 Synthesis and characterization of homoleptic compounds .............................6 60

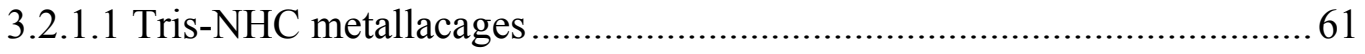

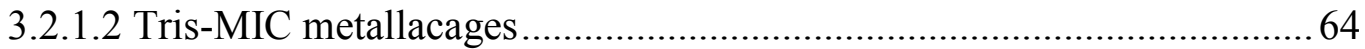

3.2.2 Synthesis and characterization of a MIC-NHC mixed metallacage ..................67 67

3.2.2.1 Reactivity studies and ligand exchange reactions ...............................69

3.3 Conclusions...................................................................................................... 72

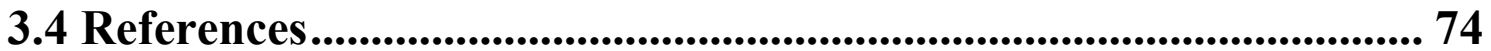

\section{Chapter 4}

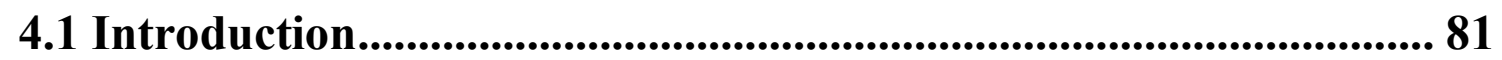

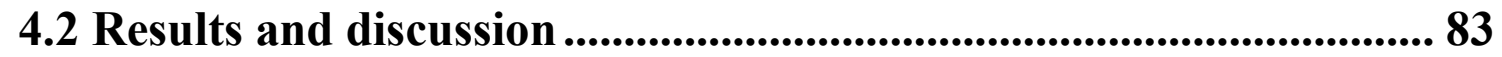

4.2.1 Synthesis and characterization of corannulene-linked bis-imidazolium salts ... 83

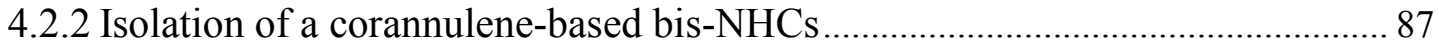

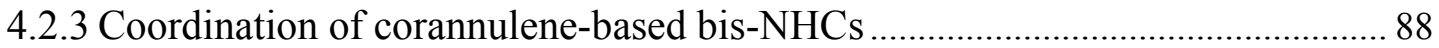

4.2.3.1 Synthesis and characterization of rhodium complexes ............................. 89

4.2.3.2 Synthesis and characterization of a gold complex ................................... 91

4.2.4 Electronic properties of the corannulene-based bis-NHC ligand ........................ 92

4.2.5 Catalytic studies of the Corannulene-bis-NHC di-Au ${ }^{\mathrm{I}}$ complexes. ..................... 94

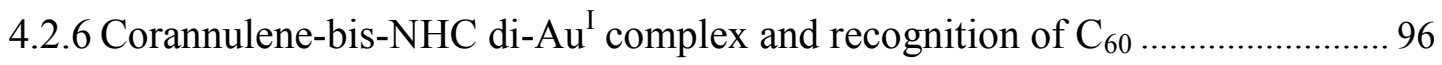

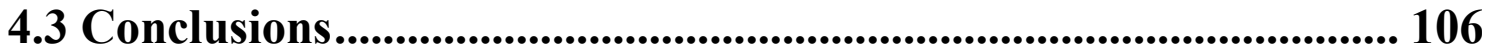

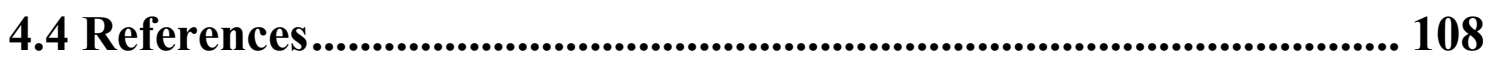




\section{Chapter 5}

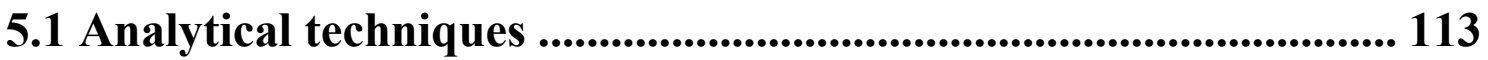

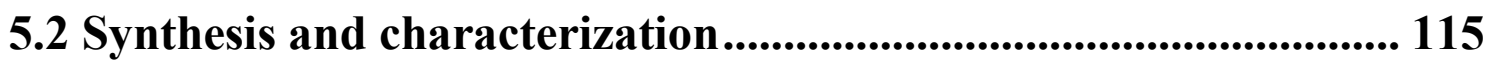

5.2.1 Synthesis and characterization of azolium and triazolium salts: Chapter 2 and 3

5.2.2 Synthesis and characterization of azolium salts: Chapter 4.

5.2.3 Synthesis and characterization of metal complexes: Chapter 2 121

5.2.4 Synthesis and characterization of metal complexes: Chapter 3 130

5.2.5 Synthesis and characterization of metal complexes: Chapter 4

5.3 Catalytic experiments: Chapter 2 and 4 ......................................... 135

5.4 DFT experiments: Chapter 3..................................................................... 136

5.5 Titration experiments............................................................................... 137

5.6 X-Ray diffraction .......................................................................... 147

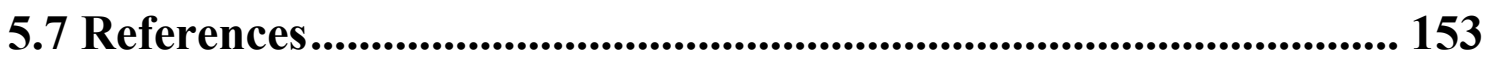




\section{Nomenclature}

The nomenclature employed to name the compounds described in this work is:

Ligands or organic intermediates in the synthesis of imidazolium salt: letters of the alphabet (A-G). In the cases where a compound could bear different substituents, their nature $(\mathrm{Me}, \mathrm{Et}, \ldots)$ will be included next to the letter of the alphabet.

Ligands salts precursors: the ligand letter with the acidic protons and its counter-ion. For example, $\left[\mathbf{H}_{3} \mathbf{B}^{\mathrm{Et}}\right]\left(\mathbf{P F}_{6}\right)_{3}$ is the precursor salt of the ligand $\mathrm{B}$ which contains three acidic $\mathrm{C}-\mathrm{H}$ bonds and three hexafluorophosphate as counter-ions.

Metal complexes with NHC ligands: the number followed by the letter of the coordinated ligand. The complexes have been sorted in order of appearance in the text.

\section{List of Abbreviations}

$\begin{array}{ll}\Delta & \text { Refluxing temperature } \\ \AA & \text { Ångström } \\ \phi & \text { Ligand hapticity } \\ \lambda & \text { Quantum yield } \\ \varepsilon_{\mathrm{r}} & \text { Wavelength } \\ \nu & \text { Relative error } \\ \text { Ar } & \text { Frequency } \\ \text { av } & \text { Aryl } \\ \text { CCDC } & \text { average } \\ \text { Cat. } & \text { Cambridge Crystallographic Data Centre } \\ \text { Conv. } & \text { Catalyst } \\ \text { COD } & \text { Conversion } \\ \text { Cp } & \text { Cyclopentadienyl } \\ \text { Cp* } & 1,2,3,4,5 \text {-pentamethylcyclopentadienyl } \\ \text { CV } & \text { Cyclic Voltammetry } \\ \text { DFT } & \text { Density Functional Theory } \\ \text { DMF } & \text { Dimethylformamide } \\ \text { DPV } & \text { Differential Pulse Voltammetry } \\ & \end{array}$




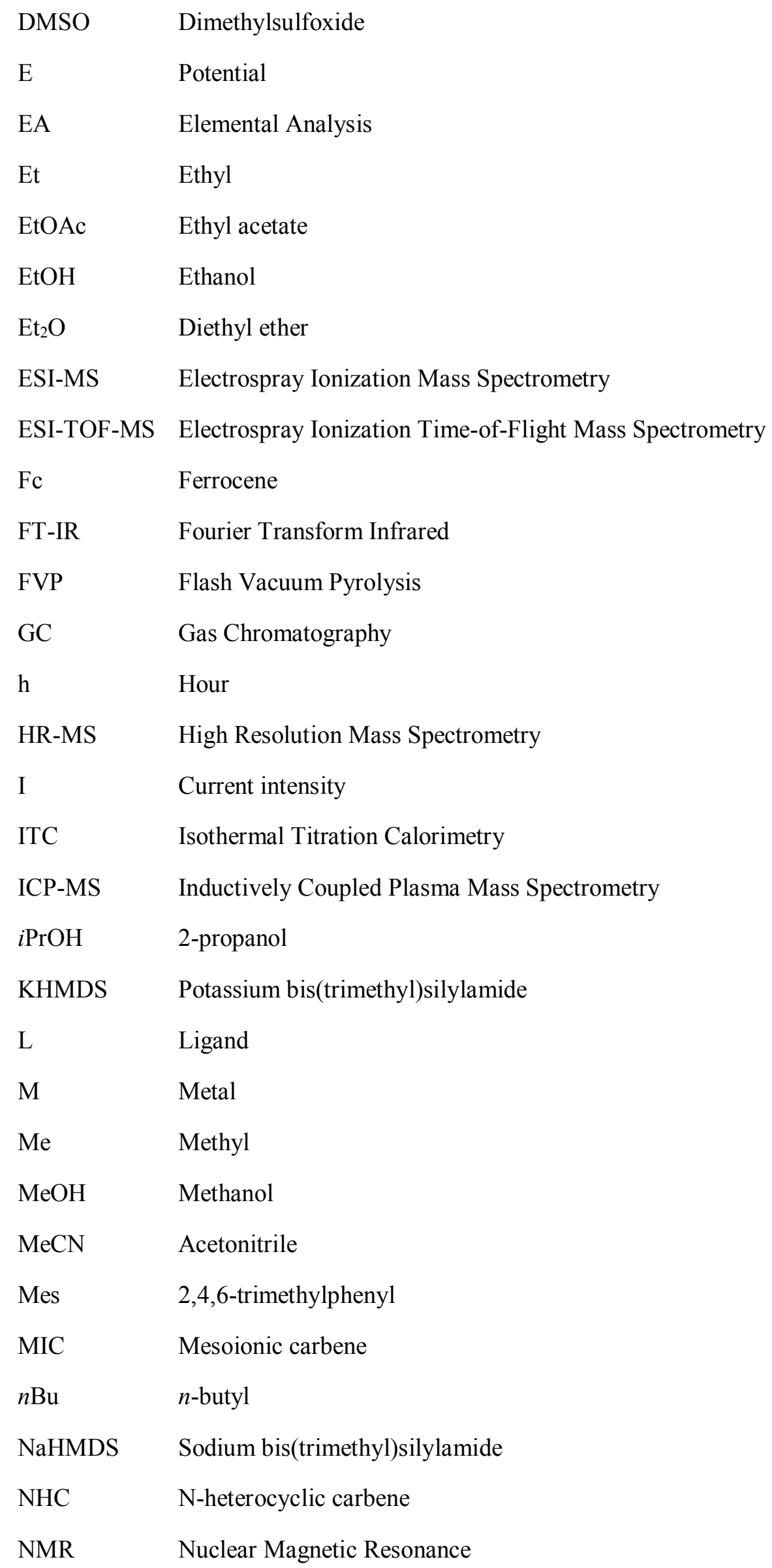




\begin{tabular}{|c|c|c|}
\hline & $\delta$ & Chemical shift \\
\hline & br & broad \\
\hline . & $d$ & doublet \\
\hline . & $J$ & coupling constant \\
\hline & $\mathrm{m}$ & multiplet \\
\hline & ppm & parts per milion \\
\hline & s & singlet \\
\hline t & $\mathrm{t}$ & triplet \\
\hline OAc & & Acetate \\
\hline $\mathrm{O} t \mathrm{Bu}$ & & tert-butoxide \\
\hline OTf & & Triflate \\
\hline PAH & & Policyclic Aromatic Hydrocarbon \\
\hline $\mathrm{Ph}$ & & Phenyl \\
\hline RT & & Room Temperature \\
\hline $\mathrm{SCC}$ & & Supramolecular Coordination Complex \\
\hline SCE & & Saturated Calomel Electrode \\
\hline $\mathrm{SMe}$ & & Methyl Sulfide \\
\hline $\mathrm{t}$ & & Time \\
\hline $\operatorname{trz}$ & & triazolylidene \\
\hline $\mathrm{T}$ & & Temperature \\
\hline$t \mathrm{Bu}$ & & tert-butyl \\
\hline TEP & & Tolman Electronic Parameter \\
\hline THF & & Tetrahydrofuran \\
\hline $\mathrm{UV} / \mathrm{Vis}$ & & Ultraviolet/Visible \\
\hline $\mathrm{V}_{\text {Bur }}$ & & Buried Volume \\
\hline
\end{tabular}




En aplicación de la normativa de estudios de doctorado sobre la elaboración de Tesis Doctorales según el programa RD 99/2011 por el que se establece que: "La Tesis Doctoral escrita en una lengua diferente del valenciano o castellano, en el momento de ser depositada, debe contener un apartado suficientemente amplio en una de estas dos lenguas, y debe formar parte de la encuadernación de la tesis”. El siguiente capítulo en castellano contiene un resumen y conclusiones sobre el trabajo recogido en la presente Tesis Doctoral.

\section{Presentación de la memoria}

La presente Tesis Doctoral describe la síntesis de metalo-estructuras poliaromáticas basadas en carbenos poli-N-heterocíclicos (NHCs). La tesis se organiza en cinco capítulos, que comprenden una introducción (Capítulo 1), resultados y discusión (Capítulos 2-4), y una sección experimental (Capítulo 5).

El Capítulo 1 es una introducción que incluye conceptos relevantes para la tesis, tales como el autoensamblaje o carbenos N-heterocíclicos. También se incluye una sección que detalla el trabajo previamente desarrollado por el grupo. La revisión se organiza secuencialmente, siguiendo el orden en que se discuten los temas en los capítulos siguientes, y finaliza con los principales objetivos establecidos para el proyecto.

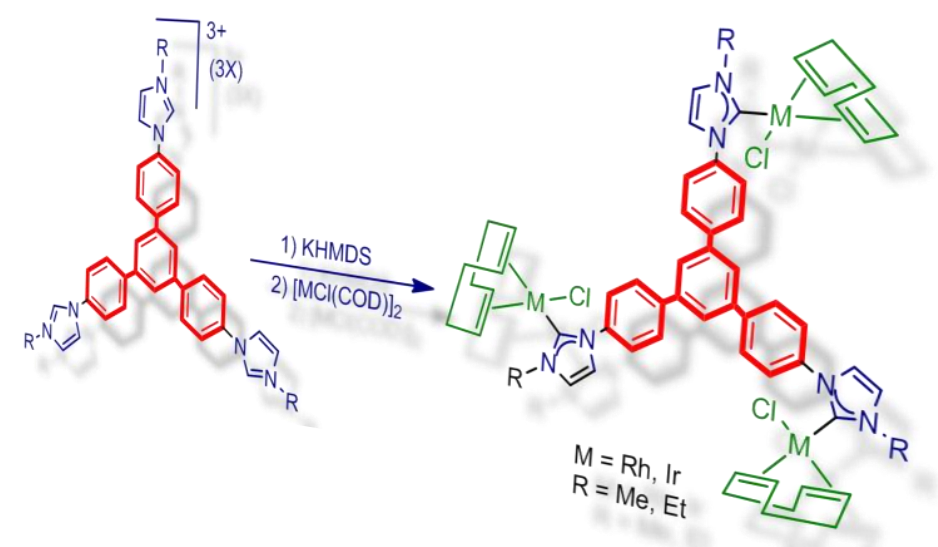

Figura 1. Imagen gráfica representativa del Capítulo 2 
El Capítulo 2 se dedica a la síntesis y caracterización de sales de tris-imidazolio y sales de tris-triazolio, basadas en un núcleo de 1,3,5-trifenilbenceno. Estas sales fueron empleadas como precursoras de carbenos N-heterocíclicos (NHCs) y carbenos mesoiónicos (MICs), y fueron coordinadas generando los correspondientes complejos metálicos. El capítulo se inicia con una breve introducción a los poli-NHCs, seguida de una discusión de los resultados. Se describe la síntesis de sales de tris-imidazolio y tristriazolio. Los estudios de luminiscencia de compuestos de tris-imidazolio por emisión de fluorescencia muestran rendimientos cuánticos comparables a los del 1,3,5-tris (4bromofenilbenceno). También se describe la síntesis de los correspondientes complejos trimetálicos de iridio $^{\mathrm{I}}$, rodio $^{\mathrm{I}}$ y níquel ${ }^{\mathrm{II}}$. Los compuestos de rodio $^{\mathrm{I}}$ e iridio ${ }^{\mathrm{I}}$ se sintetizaron por desprotonación de las sales de azolio KHMDS ó $\mathrm{K}_{2} \mathrm{CO}_{3}$ seguido de la adición de los correspondientes complejos [ $\left.\mathrm{MCl}(\mathrm{COD})_{2}\right]$. Para la obtención de los derivados de níquel, se utilizó níqueloceno como precursor metálico. La caracterización espectroscópica confirma la simetría $C_{3}$ de todos los complejos. La preparación de los derivados de carbonilo de los complejos de Rh e Ir y la medida de las frecuencias de vibración CO, permitió hacer una evaluación de la capacidad $\delta$-dadora de los correspondientes ligandos tri-NHC y tri-MIC.

Los complejos trimetálicos de rodio $^{\mathrm{I}}$ se evaluaron como catalizadores para la adición de ácidos arilborónicos a cetonas $\alpha, \beta$-insaturadas. La actividad catalítica es similar a la observada para los análogos monometálicos, sin que se observe una mejora para ligandos más donadores de electrones.

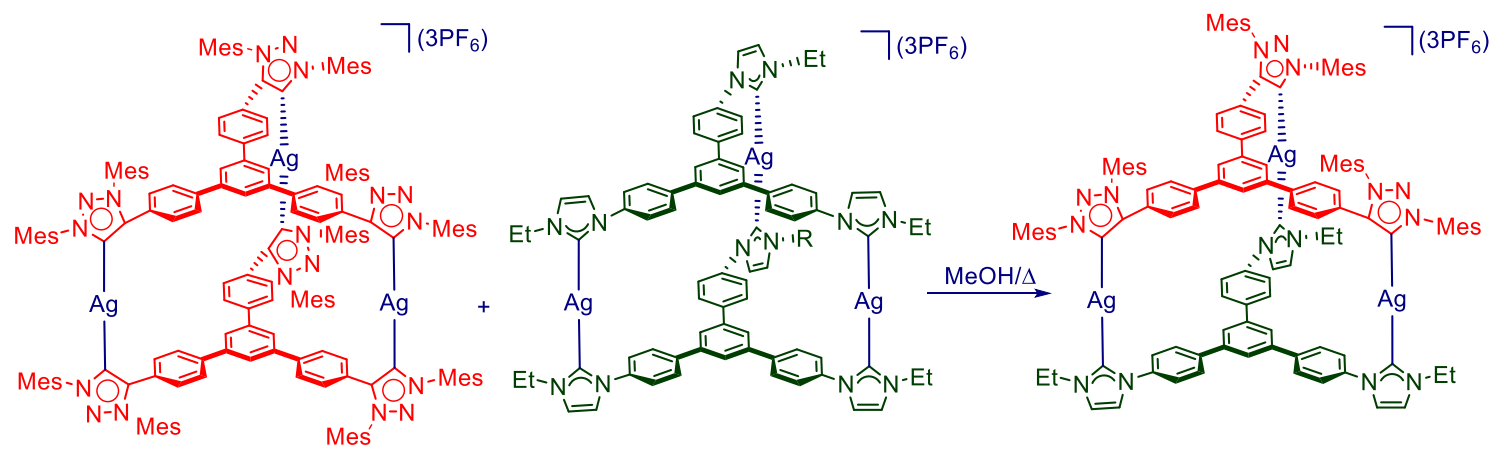

Figura 2. Imagen gráfica representativa del Capítulo 3

El Capítulo 3 describe la síntesis de estructuras auto-ensambladas (self-assembly structures) basadas en ligandos carbeno NHC y MIC. En las primeras páginas se 
muestra la síntesis de sistemas autoensamblados descritos en la literatura, y su utilización como estructuras supramoleculares. Se describe la síntesis de metalo-cajas de tris-NHC y tris-MIC con metales del grupo 11. La preparación de metalo-cajas de plata $^{\mathrm{I}}$ se describe a partir de las sales precursoras de NHC y MIC descritas en el Capítulo 2. Seguidamente se describe la preparación de las metalo-cajas de oro ${ }^{\mathrm{I}}$ y cobre ${ }^{\mathrm{I}}$ por medio de transmetalación a partir de las metalo-cajas de plata ${ }^{\mathrm{I}}$. En todos los casos se observa la formación de estructuras de geometría prismática trigonal, con una cavidad de tamaño nanométrico.

Por último, se describe la obtención de la primera metalo-caja heteroléptica, obtenida por la combinación de una sal precursora de NHC junto con, una sal precursora de MIC en presencia de $\mathrm{Ag}_{2} \mathrm{O}$. Además, esta caja de plata ${ }^{\mathrm{I}}$ heteroléptica también puede generarse usando otros procedimientos como es la mezcla de la metalo-caja homolépticas basada en ligandos NHC y MIC descritas anteriormente, produciéndose una reorganización molecular para la generación de metalo-caja heteroléptica. La estabilidad de estos complejos y las rutas sintéticas se analizaron y apoyaron adicionalmente mediante cálculos DFT.

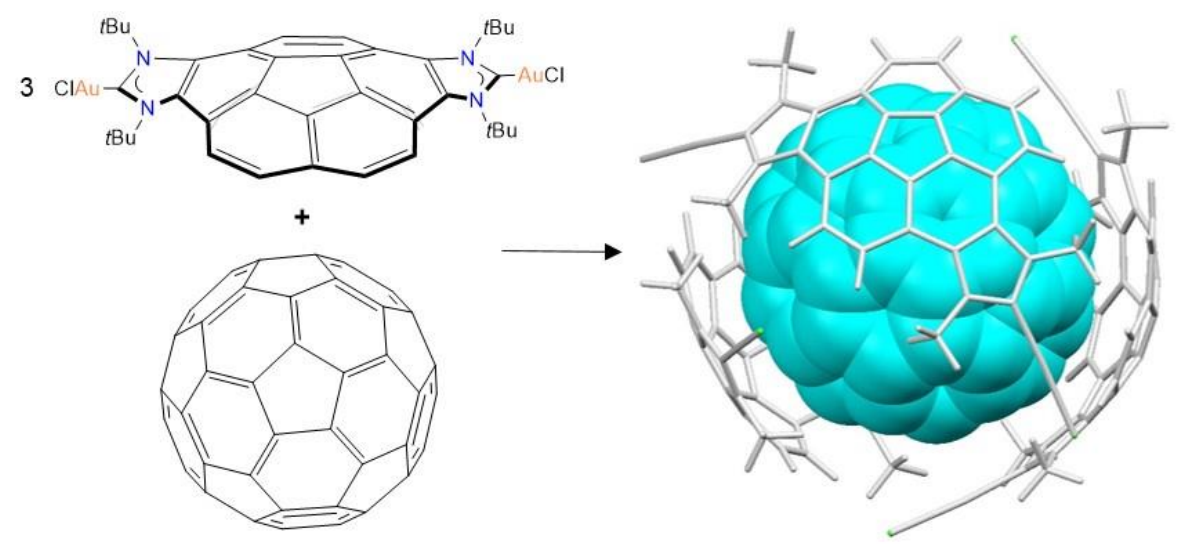

Figura 3. Imagen gráfica representativa del Capítulo 4.

El Capítulo 4 se dedica a la síntesis de carbenos N-heterocíclicos a partir de unidades de basadas en coranuleno, la evaluación de su actividad catalítica y propiedades supramoleculares. El capítulo se inicia con una breve introducción sobre los NHC poliaromáticos planos vs. curvos. Se describe la síntesis de precursores de NHC de coranuleno a partir de tetrabromo-coranuleno, a través de una tetra-aminación de Buchwald-Hartwig seguida por la anulación con tri-butil ortoformiato. Dependiendo de 
las condiciones de reacción empleadas, se pueden obtener dos sales precursoras de coranuleno con diferentes sustituyentes en el nitrógeno del anillo de imidazolio. Para la sal precursora que contiene el sustituyente más voluminoso (tert-butilo), se aisló y caracterizó su correspondiente carbeno libre. Por otro lado, se obtuvieron complejos dimetálicos de rodio $^{\mathrm{I}}$ y oro $^{\mathrm{I}}$ basados en dichos ligandos NHC previamente sintetizados. Además, se sintetizó el correspondiente derivado de di-rodio tetracarbonilo, lo que permitió el análisis y evaluación de las propiedades dadoras de los ligandos. Los valores de TEP indican un carácter menos dador a otros NHC poliaromáticos similares.

La actividad catalítica de los complejos de oro $^{\mathrm{I}}$ se evaluó en la hidroaminación de alquinos y la ciclación de 2,5-dimetilfurano con alquinos terminales. En ambos casos, el rendimiento del catalizador fue sólo moderado.

Para el complejo oro ${ }^{\mathrm{I}}$ de coranuleno, se examinó la capacidad de reconocimiento de sistemas poliaromáticos fusionados, como el fulereno- $\mathrm{C}_{60} \mathrm{y}$ el coroneno. Para ello se realizaron experimentos de valoración mediante $\mathrm{RMN}$ de protón y Calorimetría Isoterma de Titulación (ITC). Tras el análisis de los datos por ambas técnicas junto, con los cálculos teóricos realizados, se pudo concluir la formación de un sistema host-guest 3:1 una para el $\mathrm{C}_{60}$ y 1:1 para el caso del coroneno.

El Capítulo 5 contiene la sección experimental, que recopila la caracterización completa de todos los compuestos discutidos en los capítulos anteriores, detallados con datos espectroscópicos (RMN de protón y carbono, análisis elemental, espectrometría de masas y espectroscopía infrarroja en los casos que requeridos) y el procedimiento experimental llevado a cabo en casa caso. En esta sección también están incluidos los datos de fluorescencia, tablas de cálculos teóricos, espectros de emisión y absorción, espectros de voltametría cíclica, experimentos de ITC y catálisis testadas. Por último, se detallan los datos de las estructuras de rayos $\mathrm{X}$ de monocristal obtenidas a lo largo de la tesis.

En resumen, en esta Tesis Doctoral se ha sintetizado una serie de ligandos politópicos basados en ligandos NHC y MIC mediante diferentes rutas sintéticas que dieron lugar a sistemas con arquitecturas muy sofisticadas. Se ha procedido a la formación de una gran variedad de complejos metálicos basados en dichas sales precursoras que permitieron la obtención de complejos mono-, di- y tri-metálicos homo y heterolépticos con diferentes geometrías. Se han analizado las propiedades luminiscentes de varias sales de 
imidazolio, la actividad catalítica de algunos de los complejos metálicos obtenidos y se han llevado a cabo estudios de reconocimiento molecular host-guest. 



\section{Chapter 1}

\section{Introducción y Objetivos}





\subsection{Introducción}

La presente Tesis Doctoral es el fruto de un trabajo de investigación centrado en la generación de nuevas entidades estructurales que puedan ser utilizadas para la formación de arquitecturas supramoleculares y el estudio de las interacciones entre ellas. Esta tarea se ha llevado a cabo combinando dos áreas diferentes de la química, como son la química organometálica y la química supramolecular. A lo largo de la tesis doctoral irán apareciendo una serie de conceptos básicos, que serán presentados y desarrollados en esta introducción, la cual servirá como preámbulo a otra introducción, más breve y específica, en cada uno de los siguientes capítulos.

\subsubsection{Sistemas poliaromáticos funcionalizados con ligandos NHC}

La química de los carbenos, y en particular de los carbenos N-heterocíclicos (NHC), ha sido estudiada desde hace décadas. Los primeros complejos metálicos con carbenos Nheterocíclicos fueron descritos en los años 60 por autores como Lappert ${ }^{[1]}$, Öfele ${ }^{[2]}$ y Wanzlick. ${ }^{[3]}$ Posteriormente, en 1989 Bertrand y colaboradores consiguieron aislar el primer carbeno libre. ${ }^{[4]}$ Sin embargo, no fue hasta 1991 cuando Arduengo y colaboradores $^{[5]}$ aislaron el primer carbeno N-heterocíclico.

La fortaleza del enlace metal-NHC y la versatilidad coordinativa de este tipo de ligandos son posiblemente, dos de las muchas propiedades que pueden haber ayudado al gran desarrollo de la química de los carbenos N-heterocíclicos.

La relativamente sencilla preparación de precursores de NHC (normalmente sales de azolio) ha permitido el acceso casi ilimitado a nuevas topologías organometálicas. Los imidazol-ilidenos (NHC normales, abnormales o remotos), ${ }^{[6]}$ cuyos parámetros electrónicos y estéricos pueden ser modulados de forma controlada, han sido ampliamente estudiados e intensamente utilizados. Actualmente existe un amplio abanico de carbenos $\mathrm{N}$-heterocíclicos, de entre los que merecen especial mención los 1,2,3-triazol-5-ilidenos (también conocidos como NHC abnormales, o mesoionicos), que fueron descritos más recientemente, y cuya capacidad electron-dadora es ligeramente superior a la de los NHC normales. ${ }^{[6-7]}$

Entre los diferentes tipos de ligandos NHC, los poli-carbenos N-heterocíclicos han suscitado un gran interés, ya que permiten la preparación de compuestos organometálicos con una gran variedad de geometrías. ${ }^{[8]}$ Esta versatilidad topológica 
puede facilitar la síntesis controlada de complejos cuyos ligandos puedan actuar como bis-quelato, pinza, tripodal o puente.

Los ligandos de tipo tris- y tetra-NHC son menos abundantes que los di-NHC, probablemente debido a que las sales de imidazolio tris- y tetra-catiónicas resultantes son a menudo difíciles de purificar dada su baja solubilidad en la mayoría de los disolventes orgánicos. ${ }^{[8 b, 9]}$

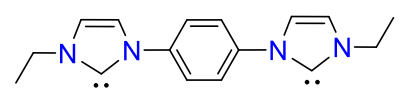

1

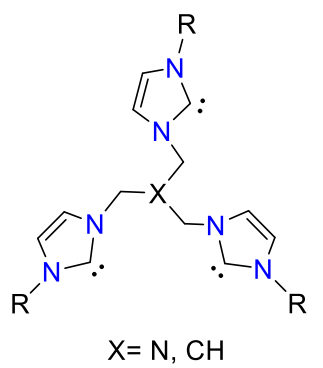

4
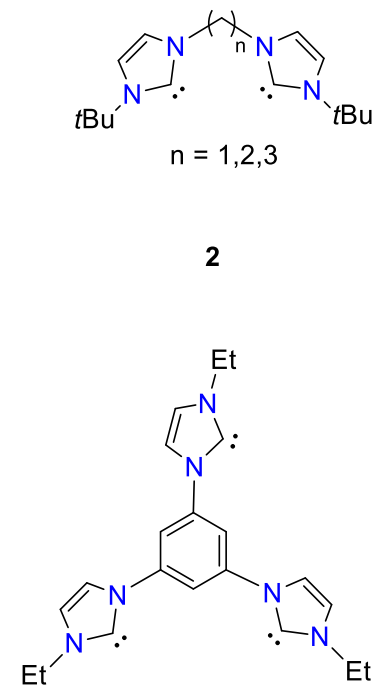

5

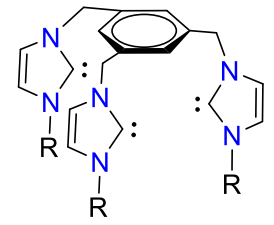

3

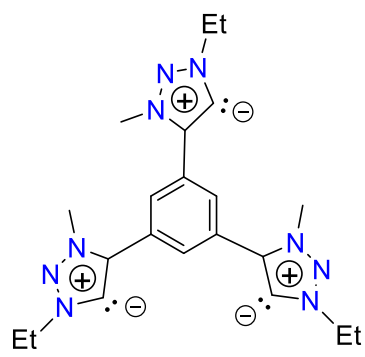

6

Figura 1.1. Ejemplos de ligandos carbenos poli-N-heterocíclicos

La síntesis de ligandos poli-NHC permite la obtención de complejos que pueden ser homo- o hetero-polimetálicos. ${ }^{[8 \mathrm{a}, 9 \mathrm{~b}, \mathrm{~d}]}$ La preparación de estos complejos polimetálicos se ha convertido en un foco de interés en el campo de la catálisis homogénea, ya que se ha comprobado que pueden presentar mayores actividades catalíticas que sus homólogos monometálicos (debido al fenómeno conocido como cooperatividad

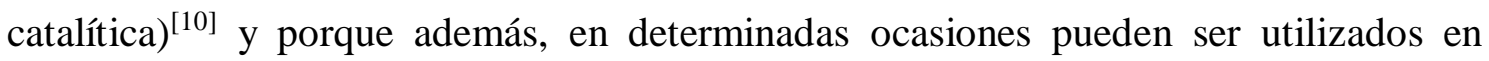
catálisis tándem. ${ }^{[11]}$ 


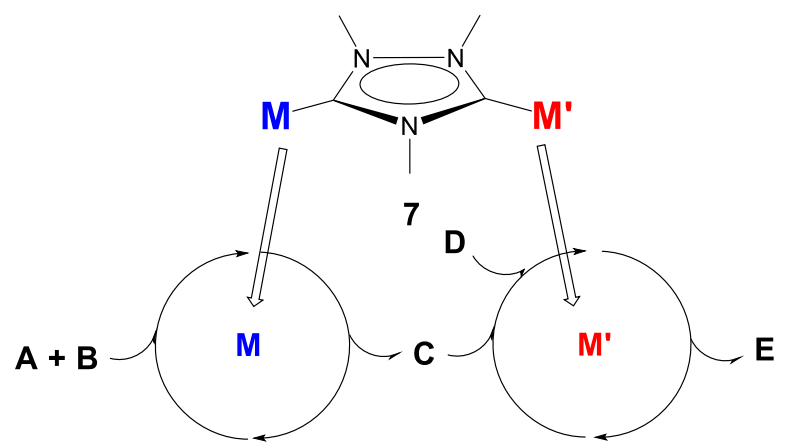

Esquema 1.1. Ejemplo de complejo hetero-bimetálico en catálisis tándem (esquema reproducido de la referencia ${ }^{[11 c]}$ )

Gracias a su versatilidad coordinativa, recientemente los ligandos poli-NHC se han utilizado para el desarrollo de complejos de coordinación supramoleculares bi- y tridimensionales $^{[9 c, 12]}$ (ver Sección 1.1.2). A modo de ejemplo, en el Esquema 1.2, se muestra cómo el ligando tris-NHC descrito por Hahn y colaboradores, ${ }^{[9 c]}$ y obtenido a partir de su sal precursora fenil-tris-imidazolio, puede servir para la generación de cajas moleculares como el complejo de Pd (9), o actuar como puente-quelato para generar el complejos dimetálicos de Rh o Ir (10).

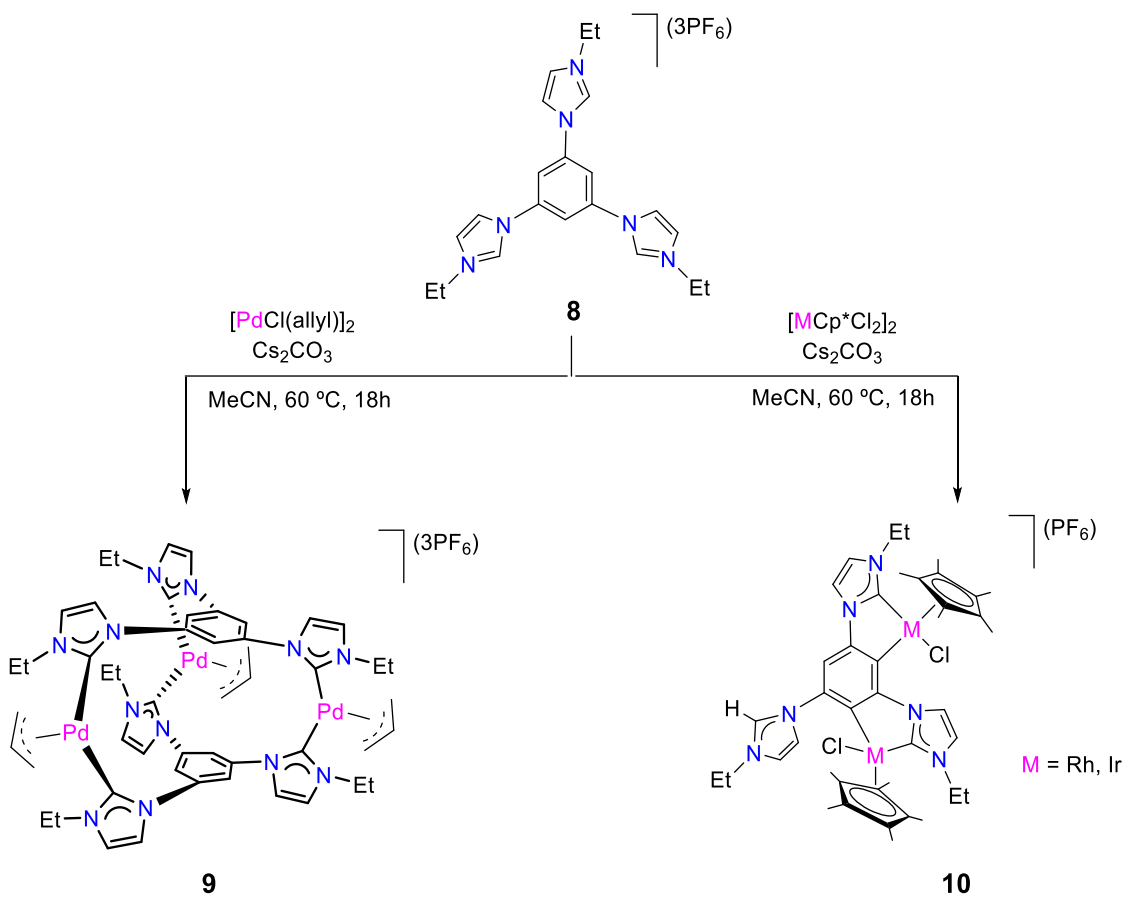

Esquema 1.2. Dos formas de coordinación de un tri-NHC ${ }^{[9 \mathrm{c}]}$

Este ejemplo ilustra cómo un mismo ligando poli-NHC se puede utilizar para la obtención de compuestos con estructuras muy variadas, ${ }^{[9 \mathrm{~d}, 13]}$ dependiendo del método de síntesis utilizado. 


\subsubsection{Reacciones de autoensamblaje (Self-Assembly)}

El autoensamblaje es un proceso por el que un sistema desordenado sufre una organización espontánea y reversible de las unidades moleculares que lo componen, llegando a formar estructuras ordenadas por interacciones de naturaleza no covalente.

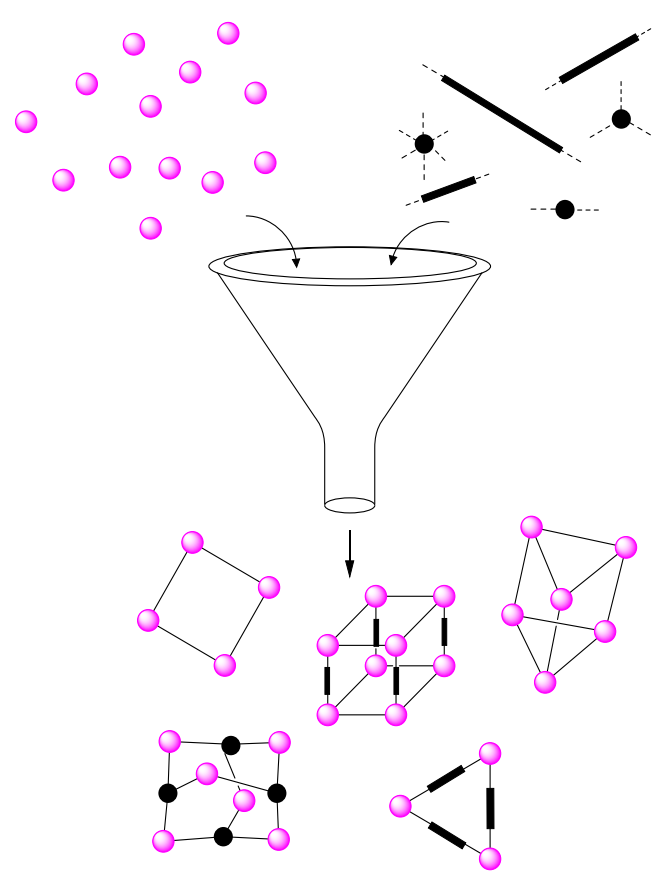

Esquema 1.3. Representación esquemática de la técnica de autoensamblaje ${ }^{[14]}$

El uso de metales de transición en procesos de autoensamblaje facilita la formación de sistemas con formas y tamaños bien definidos, tales como hélices o cajas. Los primeros trabajos en este campo de investigación se centraron en el desarrollo de diferentes métodos de autoensamblaje, gracias a los cuales se pudieron sintetizar diferentes metalociclos y metalocajas ${ }^{[14]}$ (Esquema 1.3).

La combinación de un precursor metálico con un ligando bi- o tri-dentado con la geometría adecuada, puede formar espontáneamente enlaces metal-ligando que den lugar a productos termodinámicamente favorables. ${ }^{[15]}$ Debido a que la formación de los enlaces metal-ligando es el motor de la obtención de la estructura supramolecular, a este tipo de proceso se le conoce como proceso de autoensambleje coordinativo (coordination-driven self-assembly). Los productos resultantes suelen mostrar estructuras altamente simétricas con cavidades bien definidas. ${ }^{[16]}$ La presencia de la cavidad determina una reactividad única, que puede tener aplicaciones en catálisis, ${ }^{[17]}$ reconocimiento molecular ${ }^{[18]}$ y en la estabilización de especies altamente reactivas. ${ }^{[19]}$ 
Para la obtención de sistemas metálicos supramoleculares, es muy importante seleccionar adecuadamente la forma y tamaño de los ligandos (spacers), así como la naturaleza del fragmento metálico (nodes), que normalmente va a ocupar los vértices de la estructura poligonal o poliédrica. La selección del metal es muy importante, porque su capacidad coordinativa y los ángulos de coordinación van a determinar la forma del producto resultante. La mayoría de los esfuerzos invertidos en el diseño de arquitecturas metalo-supramolecules están basados en tratar de imitar el comportamiento de las enzimas. Por lo tanto, con la presencia de ligandos polidentados y la síntesis de sus correspondientes complejos metálicos, se persigue obtener cavidades que imiten el entorno en el que se encuentran los enzimas en la naturaleza. ${ }^{[20]}$ Para la formación de dichas cavidades se necesita una matriz de varios metales, razón por la cual las moléculas metal-orgánicas con cavidades han sido definidas como 'complejos multimetálicos donde la coordinación del metal es necesaria para la formación de la cavidad'. ${ }^{[16 b]}$

El diseño de estas estructuras metalo-supramoleculares permite crear arquitecturas bidimensionales (2D) como los metalo-cíclos, o tridimensionales (3D) como las metalocajas. En ambos casos las condiciones de reacción suelen ser suaves, obteniéndose altos rendimientos aislados. En el Esquema 1.4 se muestra un ejemplo de síntesis de una serie de metalo-cajas en las que, dependiendo del espaciador empleado, puede obtenerse una cavidad de mayor o menor tamaño. Dependiendo del tamaño de la caja, el volumen interior de la cavidad será mayor o menor, determinando de éste modo el número de moléculas neutras o cargadas que se pueden albergar en su interior. 
<smiles>O=[N+]([O-])O[Pb]1([O-])NCCN1</smiles>

11

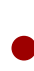

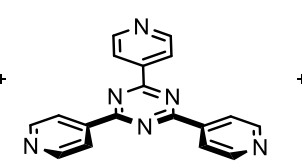

12

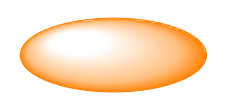

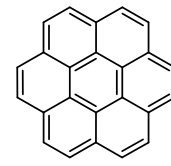

13

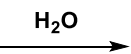

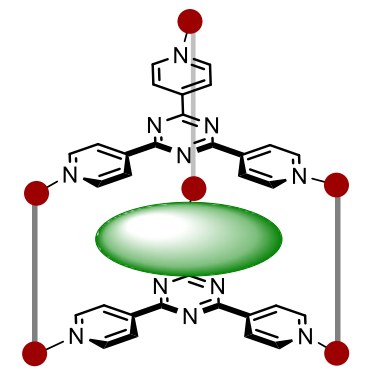

$11 @ 13$

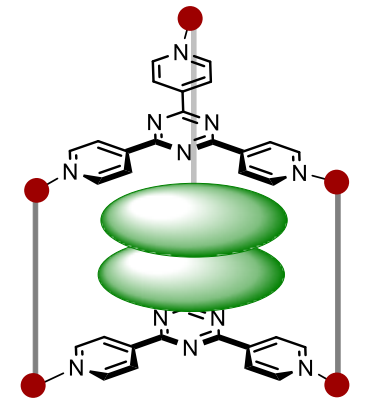

$11 @(13)_{2}$

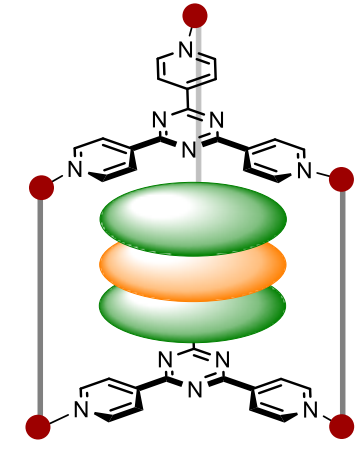

$11 @\left(12(13)_{2}\right)$
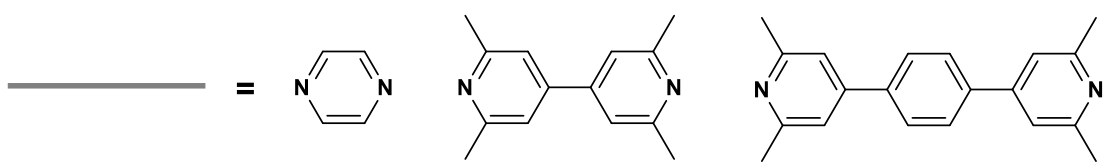

Esquema 1.4. Ejemplo de formación de un prima trigonal por autoensamblaje $\mathrm{e}^{[15 \mathrm{~d}]}$

A través de la metodología de autoensamblaje coordinativo, en nuestro grupo de investigación se ha sintetizado una serie de estructuras basadas en ligandos carbeno Nheterocíclicos que presentan cavidades en su estructura. ${ }^{[21]}$

\subsubsection{Complejos de coordinación supramoleculares (SCCs)}

Como se ha comentado anteriormente, la base para el diseño de sistemas metalosupramoleculares es la disponibilidad de ligandos rígidos con dos o más puntos de anclaje, que en combinación con los metales adecuados, formen estructuras simétricas con formas y tamaños controlables. Los complejos de coordinación supramolecular (Supramolecular Coordination Complexes, SSCs) ${ }^{[15 \mathrm{i}, \mathrm{k}]}$ son estructuras moleculares basadas en sistemas poliaromáticos que pueden dar lugar a la formación de nanocavidades. $^{[16 a, 22]}$ 


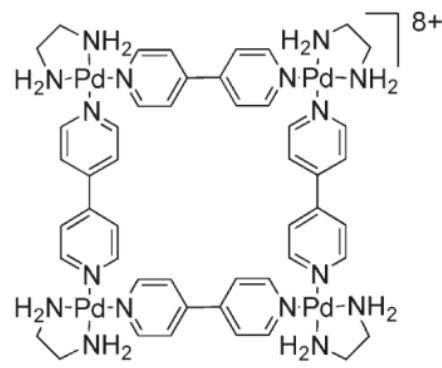

Fujita, 1990

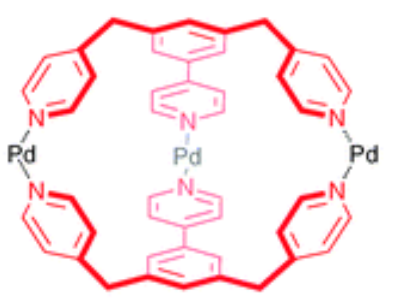

Fujita, 2000

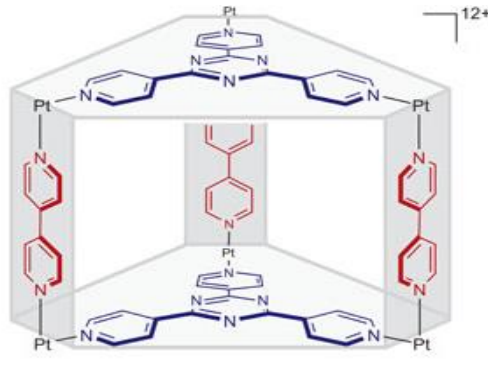

Fujita, 2003

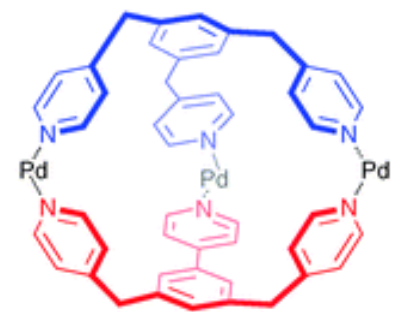

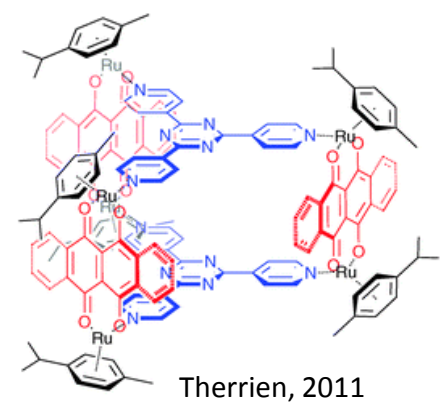

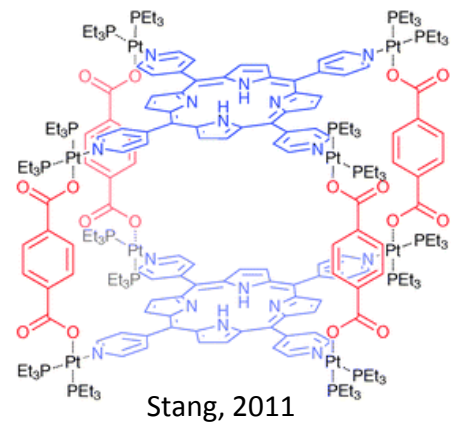

Figura 1.2. Ejemplos de complejos de coordinación supramolecular $(S S C s)^{[15 \mathrm{~d}, 23]}$

El resultado estructural de la síntesis metalo-supramolecular depende en gran medida de la naturaleza de los centros metálicos y los ligandos espaciadores (linkers) involucrados. Desde el punto de vista del diseño, dichos linkers son considerados como los elementos más importantes a tener en cuenta, ya que sus características topológicas, versatilidad y capacidad de ensamblaje, determinarán el tamaño, la geometría y la funcionalidad de las estructuras resultantes. Todo ello, combinado con la capacidad de coordinación de los metales de transición, da a este tipo de compuestos ventajas sobre los receptores orgánicos tradicionales, ${ }^{[15 d, ~ e, ~ i, ~ k, ~ 24] ~ q u e ~ p a r a ~ l o g r a r ~ o b j e t i v o s ~ s i m i l a r e s ~ a ~ m e n u d o ~}$ requieren procedimientos de síntesis muy laboriosos, altamente sofisticados y normalmente poco eficientes.

La mayoría de los sistemas metalo-supramoleculares descritos en la literatura, están basados en la utilización de ligandos polidentados de tipo Werner, por tanto están unidos a través de átomos de nitrógeno o de oxígeno. Algunos ejemplos representativos de este tipo de estructuras se muestran en la Figura 1.2.

Recientemente, el grupo de Hahn ${ }^{[13 b, 25]}$ y colaboradores han descrito un gran número de SCCs basados principalmente en carbenos poli-N-heterocíclicos (NHC). ${ }^{[8 b, 26]}$ Dichos SCCs presentan diversas geometrías, que incluyen cuadrados, rectángulos, triángulos ${ }^{[13 b}$, 21a, 25a, 27] o cilindros $^{[12 b, 13 a, 21 b, c, ~ 28]}$ moleculares. 
A pesar de la gran variedad de ejemplos recientes de estructuras bi- y tridimensionales basadas en el uso de ligandos poli-NHC, en la mayoría de los casos el volumen disponible de la cavidad es relativamente insuficiente para alojar determinadas moléculas orgánicas de interés. Este hecho podría ser el motivo por el cual existen muy pocos ejemplos de compuestos supramoleculares con ligandos NHC que hayan sido empleados como receptores para moléculas orgánicas. A consecuencia de lo anterior, a pesar del creciente número de conjuntos organometálicos SCCs conocidos, su aplicación al estudio de interacciones supramoleculares de tipo host-guest es poco frecuente, lo cual nos indujo a plantear parte de la investigación que se plantea en la presente memoria, abriendo así una nueva línea de investigación en nuestro grupo.

\subsubsection{Antecedentes en nuestro grupo de investigación: Química Organometálica y Catálisis Homogénea (QOMCAT)}

Gracias a los diferentes trabajos desarrollados en nuestro grupo de investigación, se ha podido demostrar cómo algunos catalizadores homogéneos basados en sistemas poliaromáticos, poseen propiedades claramente diferentes a las mostradas por sus análogos que no presentan sistemas poliaromáticos. ${ }^{[8]}$ La interpretación de estas diferencias se basa en la capacidad de los grupos poliaromáticos para producir interacciones no covalentes con moléculas aromáticas. ${ }^{[8 a]}$

En la Figura 1.3 se muestran algunos de los complejos polimetálicos con ligandos poliaromáticos sintetizados durante los últimos años en nuestro grupo de investigación. ${ }^{[29]}$ Estos complejos polimetálicos han sido probados en diferentes transformaciones catalíticas, en las que se ha comprobado cómo en muchos casos la actividad catalítica de los complejos polimetálicos es sensiblemente mayor que la mostrada por sus análogos monometálicos. 

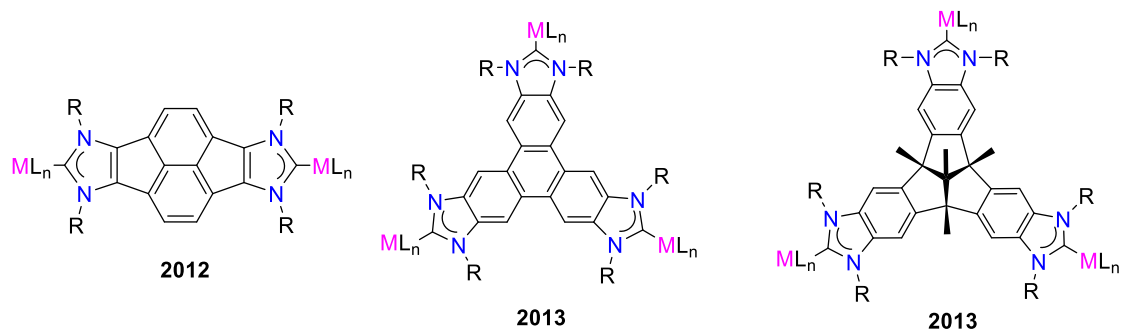

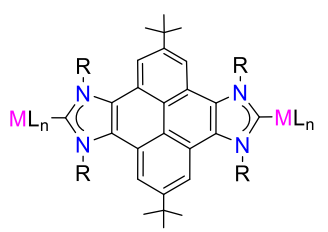

2014

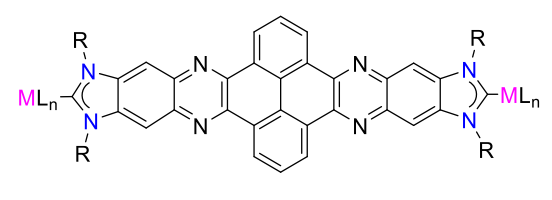

2015

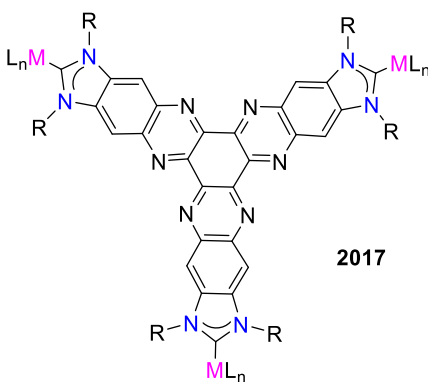

Figura 1.3. Ejemplos de complejos polimetálicos sintetizados en el grupo de investigación

Tal y como clasificaron Raynal y colaboradores en 2014, ${ }^{[17 e, 30]}$ las interacciones supramoleculares que pueden darse en catálisis homogénea son básicamente de tres tipos: interacciones ligando-ligando, interacciones aditivo-ligando e interacciones ligando-sustrato (Figura 1.4). Todas estas interacciones pueden afectar notablemente la eficacia de las reacciones catalíticas. Durante los últimos tres años, nuestro grupo de investigación ha dedicado un gran esfuerzo a estudiar de forma sistemática cómo estos tipos de interacción afectan al uso de catalizadores con ligandos NHC con sistemas poliaromáticos.

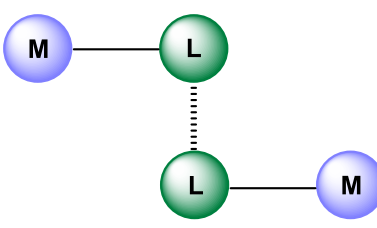

Ligando-Ligando

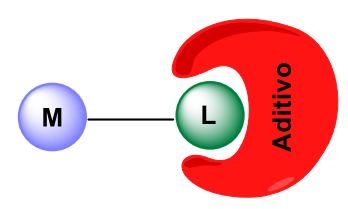

Ligando-Aditivo

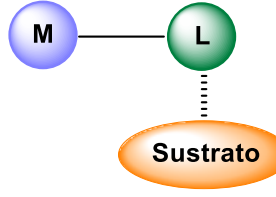

Ligando-Sustrato

Figura 1.4. Interacciones supramoleculares en catalizadores homogéneos

Paralelamente a los trabajos dedicados a estudiar la influencia de las interacciones supramoleculares en catálisis homogénea, a partir de la técnica de autoensamblaje (selfassembly $)^{[14,15 b, d, f]}$ nuestro grupo ha logrado sintetizar una serie de complejos de coordinación supramoleculares basados en ligandos pireno-di-NHC. La Figura 1.5 
muestra dos de estos compuestos, formados por cuatro centros metálicos de $\left[\mathrm{Ni}^{\mathrm{II}} \mathrm{Cp}\right]$ unidos por ligandos puentes pireno-di-NHC y bipiridina (14) o pirazina (15). Estos complejos son capaces de actuar como receptores para el reconocimiento de hidrocarburos policíclicos aromáticos (pireno, trifenileno, fenantreno y antraceno). Las contantes de asociación con estos sustratos fueron determinadas a partir de estudios de titración por espectroscopía de $\mathrm{RMN}$ de ${ }^{1} \mathrm{H}$.

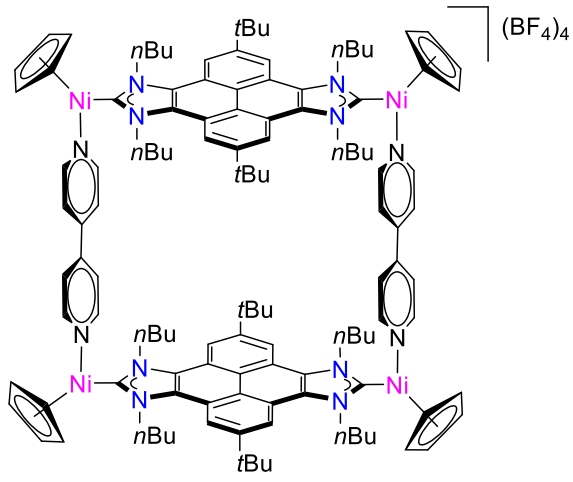

14

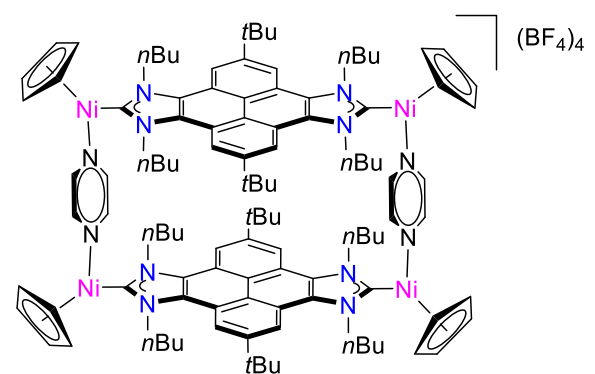

15

Figura 1.5. Ejemplos de receptores de hidrocarburos policíclicos aromáticos (PAHs)

Estos compuestos también se utilizaron como 'secuestradores' de hidrocarburos policíclicos aromáticos (PAH-scavengers). La adición de las cajas de níquel a disoluciones de heptano que contienen PAHs, produce la encapsulación del compuesto policíclico en el interior de la caja molecular, que al ser insoluble, puede separarse del medio por simple filtración. ${ }^{[21 \mathrm{~d}]}$ Teniendo en cuenta los efectos altamente perjudiciales de muchos de los PAHs en el medio ambiente, ${ }^{[31]}$ este hallazgo puede tener implicaciones importantes para proporcionar formas efectivas de extracción de PAHs.

La introducción de centros metálicos en el diseño de receptores moleculares puede proporcionar algunos beneficios en comparación con el uso de los receptores de base orgánica más ampliamente utilizados, ya que la química de coordinación a menudo proporciona estructuras predecibles y bien definidas que facilitan que los receptores diseñados tengan una forma y tamaño idónea para el reconocimiento de moléculas de interés médico o biológico. 


\subsubsection{Hidrocarburos policíclicos aromáticos $(P A H s)$}

Los hidrocarburos policíclicos aromáticos fusionados (Policyclic Aromatic Hydrocarbons, PAHs) ${ }^{[32]}$ son compuestos orgánicos basados en uno o más anillos aromáticos fusionados entre sí. La gran mayoría de estos sistemas presentan estructuras planas, aunque éstas pueden verse modificadas con la introducción de anillos de cinco miembros en el esqueleto de la mismas, dando lugar a sistemas con geometrías curvas. El trabajo realizado por nuestro grupo de investigación durante los últimos años ha estado centrado en la funcionalización de sistemas poliaromáticos planos con ligandos carbeno N-heterocíclico, lo que ha facilitado la incorporación de centros metálicos, y el estudio de sus aplicaciones.

Si bien hasta el momento, la mayor parte de la atención se había centrado en los PAHs basados sistemas $\pi$-conjugados planos, los PAHs curvos (no-planos) han resultado tener sorprendentes propiedades físicas, químicas y de ensamblaje. ${ }^{[33]} \mathrm{Al}$ mismo tiempo, permiten crear estructuras con geometrías imposibles de alcanzar con sistemas planos, como pueden ser, hélices, esferas, cilindros o cúpulas, entre otros. ${ }^{[34]}$

El Esquema 1.5 muestra las posibles subunidades de superficie curvada (coranuleno y sumaneno) que pueden derivar de un sistema esférico como es el fulereno $\mathrm{C}_{60}$.

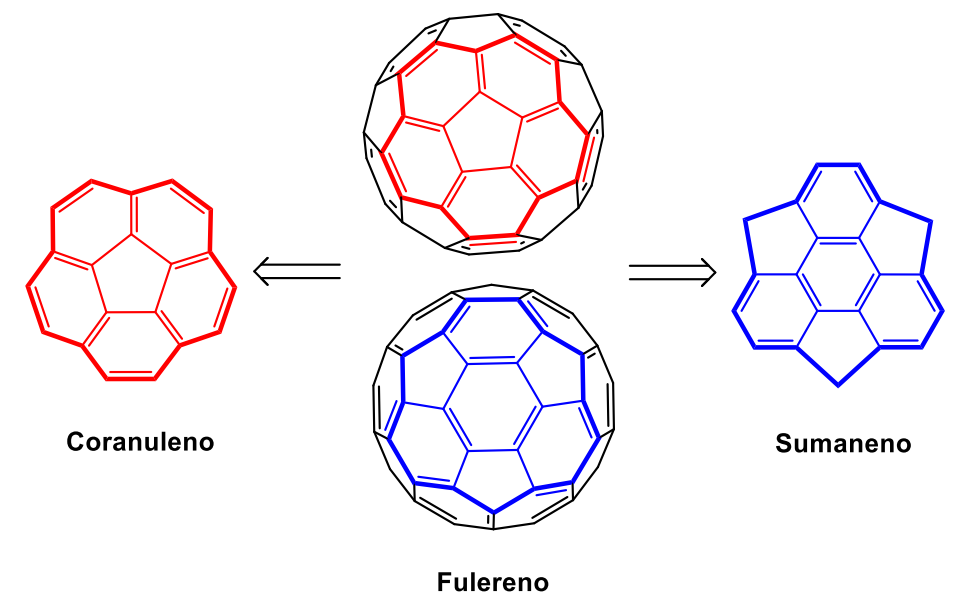

Esquema 1.5. Algunos ejemplos de hidrocarburos policíclicos aromáticos curvos

La estructura del coranuleno $\left(\mathrm{C}_{20} \mathrm{H}_{10}\right)$, considerada como una tercera parte de un fulereno $\left(\mathrm{C}_{60}\right)$, es la unidad más pequeña basada en una sistema policíclico aromático fusionado que conserva su superficie curvada.

Hace aproximadamente medio siglo, Lawton and Barth ${ }^{[35]}$ lograron publicar la primera síntesis del coranuleno, basada en 17 pasos de reacción, la cual tenía un rendimiento 
global menor del 1\%. En 1991 el grupo Scott ${ }^{[36]}$ publicó una nueva ruta sintética en la que se mejoraba el rendimiento, y donde la obtención del coranuleno está basaba en la FVP (Flash Vacuum Pyrolysis). A lo largo de los años, se ha ido mejorando la ruta sintética para su obtención, hasta poder sintetizarse en escala de kilogramos. En el Esquema 1.6 se muestra una de las rutas sintéticas "multi-kilogram scale" descritas recientemente por el grupo del Prof. Jay S. Siegel. ${ }^{[37]}$

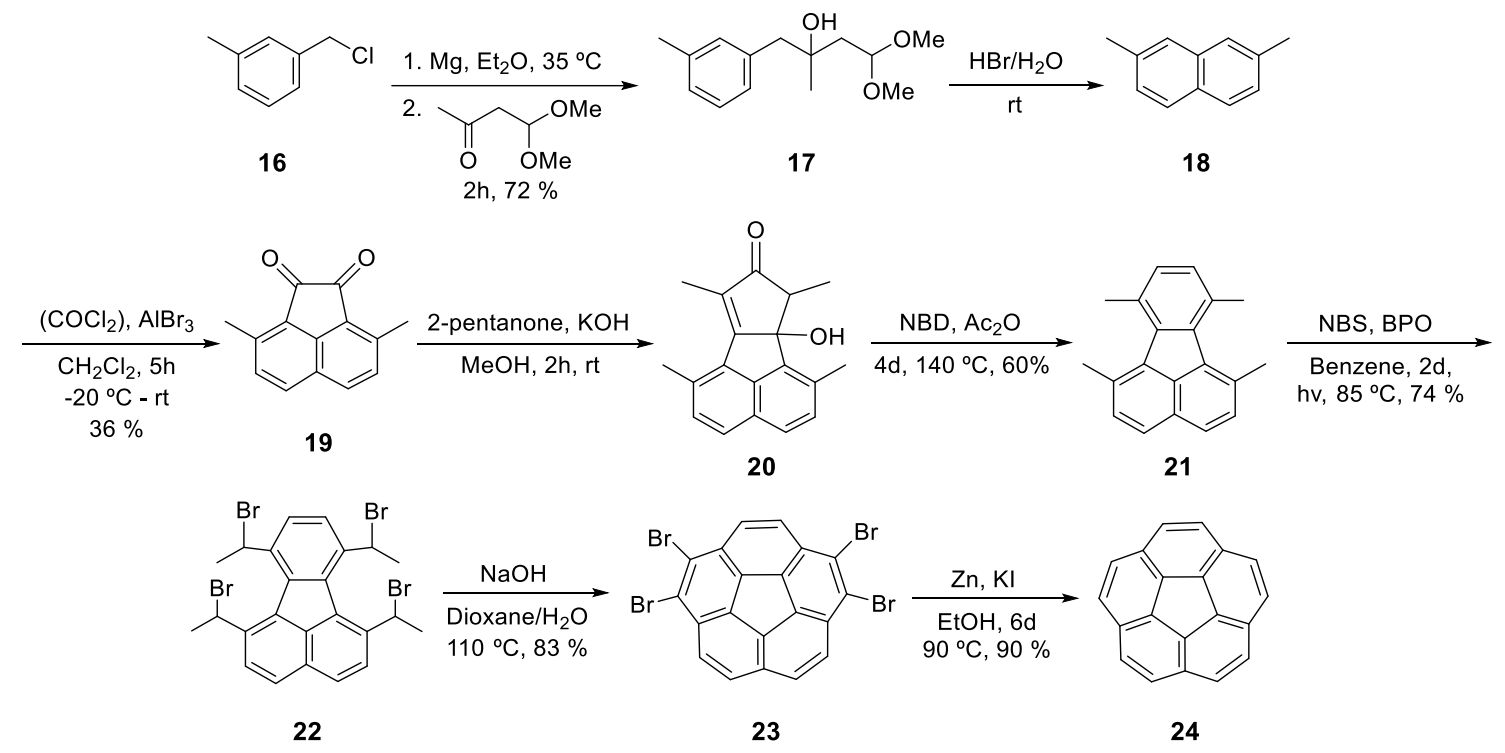

Esquema 1.6. Esquema de la "multi-kilogram scale” síntesis del coranuleno

En la bibliografía podemos encontrar una gran cantidad de trabajos basados en derivados del coranuleno, ${ }^{[38]}$ que en muchos casos se utilizan como precursores para la síntesis de nuevos materiales con múltiples aplicaciones. Cristales líquidos, superficies grafíticas, ciclofanos, polímeros o incluso dendrímeros son algunos de los ejemplos de estos materiales. $^{[39]}$

A pesar de la existencia de un elevado número de derivados orgánicos del coranuleno, el número de ejemplos funcionalizados con metales de transición es muy bajo, ${ }^{[34 \mathrm{~b}, 40]}$ lo que evidentemente justifica el escaso número de publicaciones que describen estudios de estos compuestos en campos como la catálisis, la química supramolecular o el reconocimiento molecular. 


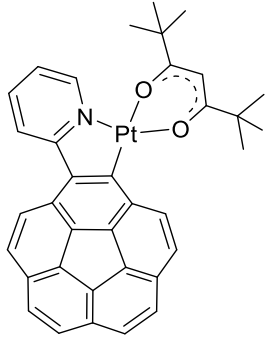

25

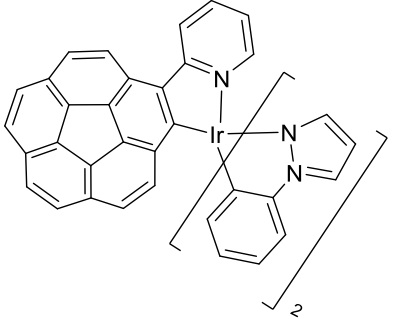

26

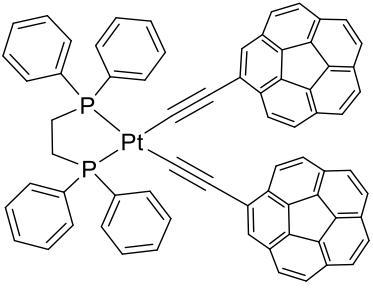

27

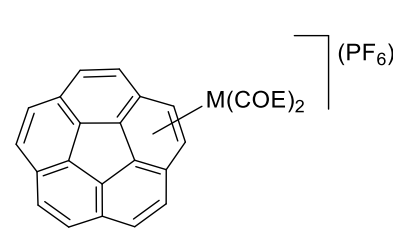

$\mathrm{M}=\mathrm{Rh}, \mathrm{Ir}$

28

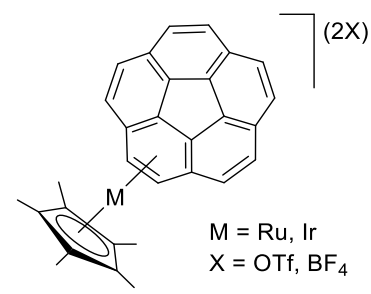

29

Figura 1.6. Algunos de los ejemplos de complejos basados en coranuleno

Actualmente no existen ejemplos de complejos metálicos con ligandos N-heterocíclico funcionalizados con coranuleno. La obtención de este tipo de ligandos podría abrir un amplio campo de posibilidades a nuevas aplicaciones, tanto en el campo de la catálisis como en el de la química supramolecular host-guest. Este es el motivo principal que nos llevó a desarrollar la investigación que se describe en el Chapter 4.

\subsubsection{Química Host-Guest y receptores supramoleculares}

La química supramolecular host-guest se centra en el estudio de las interacciones entre un receptor (host) y un huésped (guest). Por lo general, el host es una especie de mayor tamaño que el guest y presenta una cavidad en su estructura.

Existen numerosos ejemplos de hosts. Entre ellos, cabe destacar los curcubiturilos, las ciclodextrinas o los calixarenos. Todos estos sistemas son capaces de modular su forma para crear una cavidad. El guest debe tener una forma complementaría al host, lo que permitirá la afinidad y selectividad entre ambos. Cuando ambas especies interaccionan entre sí se genera el denominado complejo host-guest. ${ }^{[41]}$

El objetivo final de la química host-guest es estudiar la fortaleza, naturaleza y selectividad de las interacciones no-covalentes entre un determinado host y un guest, para provocar que el reconocimiento molecular sea más efectivo y selectivo. 


\subsubsection{Receptores moleculares para la separación de fulerenos}

Los fulerenos se pueden extraer fácilmente del hollín, pero encontrar una estrategia eficiente para obtenerlos de forma pura sigue siendo difícil, especialmente para derivados superiores a $\mathrm{C}_{70}$.

Los primeros ejemplos descritos para la purificación de los fulerenos se basaron en la sublimación controlada del hollín de carbono, en la extracción con disolventes orgánicos, o en la purificación por cristalización. Actualmente, las técnicas cromatográficas que se usan para la purificación de fulerenos requieren enormes cantidades de disolvente y pueden provocar su descomposición. Por todo lo anterior, diseñar una metodología mejorada de purificación de fulereno es una meta muy perseguida.

Como alternativa a los métodos descritos anteriormente, actualmente se está prestando gran interés al uso de receptores moleculares para la separación selectiva de fulerenos mediante interacciones host-guest. Este método no requiere un equipo especializado y además se pueden llegar a diseñar sistemas reciclables.

Los arenos basados en ciclodextrinas, ${ }^{[42]}$ calixarenos, ${ }^{[43]}$ porfirinas, ${ }^{[44]} \mathrm{O}$ metaloporfirinas, ${ }^{[45]}$ son algunos de los ejemplos de receptores de fulerenos más eficientes, especialmente cuando dos o más de estas unidades se asocian entre sí. Dichas asociaciones permiten a estos sistemas formar ensamblajes en forma de cajas moleculares, ${ }^{[46]}$ capaces de impedir o permitir la entrada de moléculas según su tamaño, lo que les convierte en excelentes sistemas para la separación de fulerenos según el número de átomos de carbono que contengan.
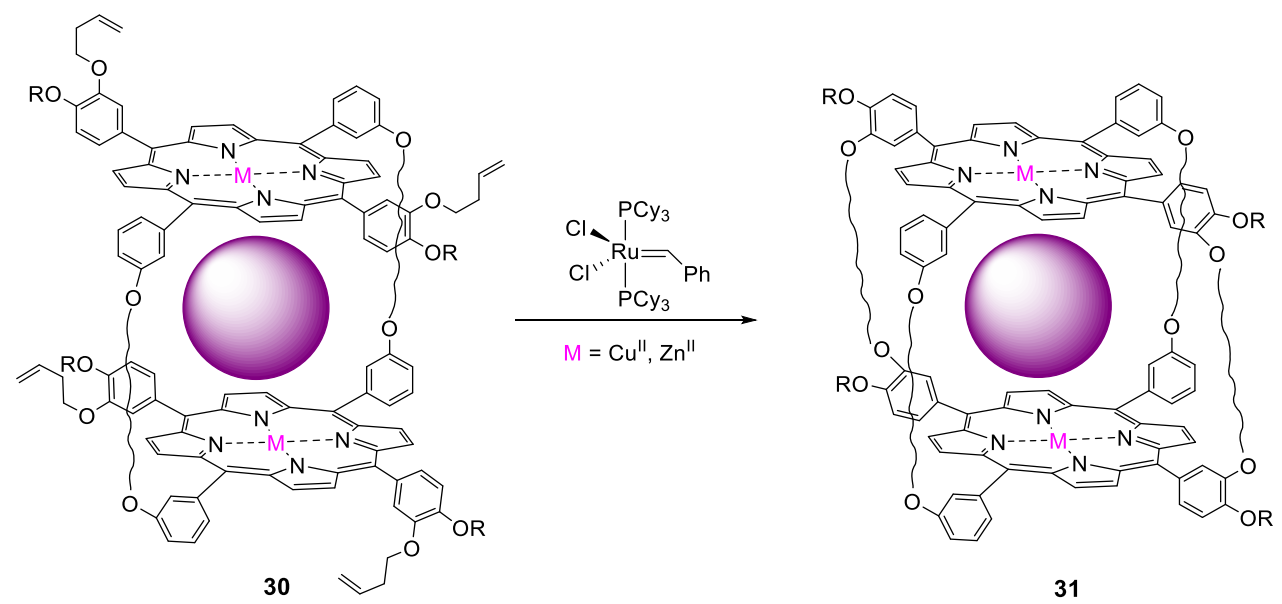

Figura 1.7. Ejemplo de caja molecular con fulereno $C_{60}$ 
Mediante el empleo de estas cajas moleculares, se ha demostrado que es posible una recuperación eficiente de los fulerenos encapsulados mediante diferentes estrategias que van desde tratamientos térmicos o ácidos, a reordenamientos conformacionales y estructurales, siendo éstos últimos los más prometedores ya que el host también puede ser parcialmente recuperado en este caso.

Por otro lado, a raíz del descubrimiento de los fulerenos ${ }^{[47]}$ y de las redes poliaromáticas de superficie curvada, surgió un gran interés por el estudio de las posibles interacciones supramoleculares derivadas del apilamiento entre ambos sistemas. ${ }^{[48]}$

Los estudios más recientes basados en el reconocimiento molecular de fulerenos tienen en común la presencia de más de un sistema poliaromático curvado. Estos sistemas son capaces de "abrazar" al fulereno como si de una pinza se tratara, dando lugar a la formación de un complejo host-guest, creándose una interacción $\pi-\pi$ entre el host (ligando pinza) y el guest (fulereno), generando situación de gran estabilidad termodinámica.

En el Capítulo 4 de esta tesis doctoral se detallará y demostrará como sistemas que contienen tres unidades de coranuleno, son capaces de reconocer fulereno $\mathrm{C}_{60}$ con una elevada constante de asociación. 


\subsection{Objetivos}

En base a la amplia colección de sistemas mono- y polimetálicos recogidos en la literatura, pero sobre todo en aquellos ejemplos desarrollados en los últimos años por nuestro grupo de investigación (QOMCAT) y así como de su gran versatilidad mostrada en diversas aplicaciones (catálisis, reconocimiento molecular, propiedades fotoluminiscentes, reacciones de autoensambaje, etc.), el objetivo general de la presente Tesis Doctoral es el desarrollo de complejos de coordinación supramolecular y receptores moleculares bimetálicos basados ligandos poliaromáticos. Éste objetivo general puede dividirse en los siguientes objetivos más específicos:

- Síntesis de sales de poli-azolio a partir de polifenilenos o sistemas aromáticos fusionados de superficie curvada para la obtención de ligandos poli-NHCs.

- Coordinación de los poli-NHCs a diferentes fragmentos metálicos, estudio de sus propiedades electrónicas y evaluación de su actividad catalítica.

- Obtención de complejos de coordinación supramolecular (SCCs) por autoensamblaje a partir de sistemas poliaromáticos funcionalizados con poliNHCs.

- Estudio de las interacciones supramoleculares tipo host-guest existentes entre sistemas basados en superficies curvadas. 


\subsection{Referencias}

[1] a) D. J. Cardin, B. Cetinkaya and M. F. Lappert, Chem. Rev. 1972, 72, 545-574;

b) D. J. Cardin, B. Cetinkaya, M. J. Doyle and M. F. Lappert, Chem. Soc. Rev. 1973, 2, 99-144; c) M. F. Lappert, J. Organomet. Chem. 1988, 358, 185-214; d) M. V. Baker, S. K. Brayshaw, B. W. Skelton, A. H. White and C. C. Williams, J. Organomet. Chem. 2005, 690, 2312-2322.

[2] K. Ofele, J. Organomet. Chem. 1968, 12, 42.

[3] H. W. Wanzlick and H. J. Schönherr, Angew. Chem. Int. Ed. 1968, 7, 141.

[4] D. Bourissou, O. Guerret, F. P. Gabbai and G. Bertrand, Chem. Rev. 2000, 100, 39.

[5] A. J. Arduengo, R. L. Harlow and M. Kline, J. Am. Chem. Soc. 1991, 113, 361363.

[6] R. H. Crabtree, Coord. Chem. Rev. 2013, 257, 755-766.

[7] G. Guisado-Barrios, J. Bouffard, B. Donnadieu and G. Bertrand, Angew. Chem. Int. Ed. 2010, 49, 4759-4762.

[8] a) E. Peris, Chem. Commun. 2016, 52, 5777-5787; b) M. Poyatos, J. A. Mata and E. Peris, Chem. Rev. 2009, 109, 3677-3707.

[9] a) R. Maity, M. van der Meer and B. Sarkar, Dalton Trans. 2015, 44, 46-49; b) R. Maity, H. Koppetz, A. Hepp and F. E. Hahn, J. Am. Chem. Soc. 2013, 135, 49664969; c) R. Maity, A. Rit, C. Schulte to Brinke, C. G. Daniliuc and F. E. Hahn, Chem. Commun. 2013, 49, 1011-1013; d) R. Maity, C. Schulte to Brinke and F. E. Hahn, Dalton Trans. 2013, 42, 12857-12860.

[10] a) M. E. Broussard, B. Juma, S. G. Train, W. J. Peng, S. A. Laneman and G. G. Stanley, Science 1993, 260, 1784-1788; b) W. J. Peng, S. G. Train, D. K. Howell, F. R. Fronczek and G. G. Stanley, Chem. Commun. 1996, 2607-2608.

[11] a) S. Sabater, J. A. Mata and E. Peris, Chem. Eur. J. 2012, 18, 6380-6385; b) J. A. Mata, F. E. Hahn and E. Peris, Chem. Sci. 2014, 5, 1723; c) S. Sabater, J. A. Mata and E. Peris, Nat. Commun. 2013, 4, 2553; d) S. Sabater, J. A. Mata and E. Peris, Eur. J. Inorg. Chem. 2013, 4764-4769.

[12] a) A. Rit, T. Pape and F. E. Hahn, Organometallics 2011, 30, 6393-6401; b) A. Rit, T. Pape, A. Hepp and F. E. Hahn, Organometallics 2011, 30, 334-347.

[13] a) C. Radloff, H. Y. Gong, C. Schulte to Brinke, T. Pape, V. M. Lynch, J. L. Sessler and F. E. Hahn, Chem. Eur. J. 2010, 16, 13077-13081; b) M. 
Schmidtendorf, T. Pape and F. E. Hahn, Angew. Chem. Int. Ed. 2012, 51, 21952198.

[14] B. J. Holliday and C. A. Mirkin, Angew. Chem. Int. Ed. 2001, 40, 2022-2043.

[15] a) E. C. Constable, Coord. Chem. Rev. 2008, 252, 842-855; b) M. Fujita, M. Tominaga, A. Hori and B. Therrien, Acc. Chem. Res. 2005, 38, 369-378; c) M. Fujita, Chem. Soc. Rev. 1998, 27, 417-425; d) R. Chakrabarty, P. S. Mukherjee and P. J. Stang, Chem. Rev. 2011, 111, 6810-6918; e) S. Leininger, B. Olenyuk and P. J. Stang, Chem. Rev. 2000, 100, 853-907; f) P. J. Stang and B. Olenyuk, Acc. Chem. Res. 1997, 30, 502-518; g) A. M. Castilla, W. J. Ramsay and J. R. Nitschke, Acc. Chem. Res. 2014, 47, 2063-2073; h) L. Chen, Q. Chen, M. Wu, F. Jiang and M. Hong, Acc. Chem. Res. 2015, 48, 201-210; i) T. R. Cook and P. J. Stang, Chem. Rev. 2015, 115, 7001-7045; j) X. Su and I. Aprahamian, Chem. Soc. Rev. 2014, 43, 1963-1981; k) T. R. Cook, Y.-R. Zheng and P. J. Stang, Chem. Rev. 2013, 113, 734-777; 1) B. Linton and A. D. Hamilton, Chem. Rev. 1997, 97, 1669-1680.

[16] a) P. Ballester, M. Fujita and J. Rebek, Jr., Chem. Soc. Rev. 2015, 44, 392-393; b) P. D. Frischmann and M. J. MacLachlan, Chem. Soc. Rev. 2013, 42, 871-890.

[17] a) C. J. Brown, F. D. Toste, R. G. Bergman and K. N. Raymond, Chem. Rev. 2015, 115, 3012-3035; b) S. H. A. M. Leenders, R. Gramage-Doria, B. de Bruin and J. N. H. Reek, Chem. Soc. Rev. 2015, 44, 433-448; c) P. Dydio and J. N. H. Reek, Chem. Sci. 2014, 5, 2135-2145; d) T. S. Koblenz, J. Wassenaar and J. N. H. Reek, Chem. Soc. Rev. 2008, 37, 247-262; e) M. Raynal, P. Ballester, A. VidalFerran and P. W. N. M. van Leeuwen, Chem. Soc. Rev. 2014, 43, 1660-1733.

[18] a) S. Dong, B. Zheng, F. Wang and F. Huang, Acc. Chem. Res. 2014, 47, 19821994; b) K. Ariga, H. Ito, J. P. Hill and H. Tsukube, Chem. Soc. Rev. 2012, 41, 5800-5835; c) B. Chen, S. Xiang and G. Qian, Acc. Chem. Res. 2010, 43, $1115-$ 1124.

[19] A. Galan and P. Ballester, Chem. Soc. Rev. 2016, 45, 1720-1737.

[20] J.-N. Rebilly, B. Colasson, O. Bistri, D. Over and O. Reinaud, Chem. Soc. Rev. 2015, 44, 467-489.

[21] a) C. Mejuto, G. Guisado-Barrios, D. Gusev and E. Peris, Chem. Commun. 2015, 51, 13914-13917; b) N. Sinha, F. Roelfes, A. Hepp, C. Mejuto, E. Peris and F. E. Hahn, Organometallics 2014, 33, 6898-6904; c) C. Segarra, G. Guisado-Barrios, 
F. E. Hahn and E. Peris, Organometallics 2014, 33, 5077-5080; d) V. MartínezAgramunt, S. Ruiz-Botella and E. Peris, Chem. Eur. J. 2017, 23, 1-8.

[22] a) C. Garcia-Simon, R. Gramage-Doria, S. Raoufmoghaddam, T. Parella, M. Costas, X. Ribas and J. N. H. Reek, J. Am. Chem. Soc. 2015, 137, 2680-2687; b) F. Hof, S. L. Craig, C. Nuckolls and J. Rebek, Angew. Chem. Int. Ed. 2002, 41, 1488-1508.

[23] a) M. Fujita, J. Yazaki and K. Ogura, J. Am. Chem. Soc. 1990, 112, 5645-5647; b) N. P. E. Barry, O. Zava, P. J. Dyson and B. Therrien, Chem. Eur. J. 2011, 17, 9669-9677; c) K. Kumazawa, K. Biradha, T. Kusukawa, T. Okano and M. Fujita, Angew. Chem. Int. Ed. 2003, 42, 3909-3913.

[24] a) C. J. Jones, Chem. Soc. Rev. 1998, 27, 289-299; b) Y.-F. Han, H. Li and G.-X. Jin, Chem. Commun. 2010, 46, 6879-6890; c) S.-S. Li, B. H. Northrop, Q.-H. Yuan, L.-J. Wan and P. J. Stang, Acc. Chem. Res. 2009, 42, 249-259.

[25] a) F. M. Conrady, R. Fröhlich, C. Schulte to Brinke, T. Pape and F. E. Hahn, J. Am. Chem. Soc. 2011, 133, 11496-11499; b) M. Schmidtendorf, T. Pape and F. E. Hahn, Dalton Trans. 2013, 42, 16128-16141; c) M. Schmidtendorf, C. S. T. Brinke and F. E. Hahn, J. Organomet. Chem. 2014, 751, 620-627.

[26] J. A. Mata, M. Poyatos and E. Peris, Coord. Chem. Rev. 2007, 251, 841-859.

[27] a) F. E. Hahn, C. Radloff, T. Pape and A. Hepp, Organometallics 2008, 27, 64086410; b) C. Radloff, F. E. Hahn, T. Pape and R. Fröhlich, Dalton Trans. 2009, 7215-7222; c) M. Viciano, M. Sanau and E. Peris, Organometallics 2007, 26, 6050-6054.

[28] a) F. E. Hahn, C. Radloff, T. Pape and A. Hepp, Chem. Eur. J. 2008, 14, 1090010904; b) A. Rit, T. Pape and F. E. Hahn, J. Am. Chem. Soc. 2010, 132, 45724573; c) D. H. Wang, B. G. Zhang, C. He, P. Y. Wu and C. Y. Duan, Chem. Commun. 2010, 46, 4728-4730.

[29] a) A. Prades, E. Peris and M. Alcarazo, Organometallics 2012, 31, 4623-4626; b) S. Ibanez-Maella, M. Poyatos and E. Peris, Chem. Commun. 2017; c) S. Gonell, M. Poyatos and E. Peris, Angew. Chem. Int. Ed. 2013, 52, 7009-7013; d) C. Segarra, J. Linke, E. Mas-Marza, D. Kuck and E. Peris, Chem. Commun. 2013, 49, 10572-10574; e) S. Gonell, M. Poyatos and E. Peris, Chem. Eur. J. 2014, 20, 9716-9724; f) H. Valdes, M. Poyatos and E. Peris, Organometallics 2015, 34, 1725-1729. 
[30] M. Raynal, P. Ballester, A. Vidal-Ferran and P. W. N. M. van Leeuwen, Chem. Soc. Rev. 2014, 43, 1734-1787.

[31] a) I. J. Keyte, R. M. Harrison and G. Lammel, Chem. Soc. Rev. 2013, 42, 93339391; b) A. K. Haritash and C. P. Kaushik, J. Hazard. Mater. 2009, 169, 1-15; c) C. L. Lemieux, A. B. Lambert, S. Lundstedt, M. Tysklind and P. A. White, Environ. Toxicol. Chem. 2008, 27, 978-990; d) K. Srogi, Environ. Chem. Lett. 2007, 5, 169-195.

[32] a) L. Zhang, Y. Cao, N. S. Colella, Y. Liang, J. L. Bredas, K. N. Houk and A. L. Briseno, Acc. Chem. Res. 2015, 48, 500-509; b) L. T. Scott, Chem. Soc. Rev. 2015, 44, 6464-6471; c) P. G. Ghasemabadi, T. G. Yao and G. J. Bodwell, Chem. Soc. Rev. 2015, 44, 6494-6518.

[33] N. Martin and L. T. Scott, Chem. Soc. Rev. 2015, 44, 6397-6400.

[34] a) P. W. Rabideau and A. Sygula, Acc. Chem. Res. 1996, 29, 235-242; b) Y.-T. Wu and J. S. Siegel, Chem. Rev. 2006, 106, 4843-4867; c) V. M. Tsefrikas and L. T. Scott, Chem. Rev. 2006, 106, 4868-4884; d) T. Higashino, J. M. Lim, T. Miura, S. Saito, J.-Y. Shin, D. Kim and A. Osuka, Angew. Chem. Int. Ed. 2010, 49, 49504954; e) T. Amaya and T. Hirao, Chem. Commun. 2011, 47, 10524-10535; f) M. Stepien, N. Sprutta and L. Latos-Grazynski, Angew. Chem. Int. Ed. 2011, 50, 4288-4340; g) M. Stepien, B. Szyszko and L. Latos-Grazynski, J. Am. Chem. Soc. 2010, 132, 3140-3152; h) S. Higashibayashi and H. Sakurai, Chem. Lett. 2011, 40, 122-128; i) A. Sygula, Eur. J. Org. Chem. 2011, 1611-1625; j) T. Higashino, B. S. Lee, J. M. Lim, D. Kim and A. Osuka, Angew. Chem. Int. Ed. 2012, 51, 1310513108; k) Y. Shen and C.-F. Chen, Chem. Rev. 2012, 112, 1463-1535; 1) H. Omachi, Y. Segawa and K. Itami, Acc. Chem. Res. 2012, 45, 1378-1389; m) E. Gonka, P. J. Chmielewski, T. Lis and M. Stepien, J. Am. Chem. Soc. 2014, 136, 16399-16410; n) K. Y. Cheung, X. Xu and Q. Miao, J. Am. Chem. Soc. 2015, 137, 3910-3914; o) T. Amaya and T. Hirao, Chemical Record 2015, 15, 310-321.

[35] a) R. G. Lawton and W. E. Barth, J. Am. Chem. Soc. 1971, 93, 1730-1745; b) W. E. Barth and R. G. Lawton, J. Am. Chem. Soc. 1966, 88, 380-\&.

[36] L. T. Scott, M. M. Hashemi, D. T. Meyer and H. B. Warren, J. Am. Chem. Soc. 1991, 113, 7082-7084.

[37] A. M. Butterfield, B. Gilomen and J. S. Siegel, Org. Process Res. Dev. 2012, 16, 664-676. 
[38] a) Y. T. Wu, D. Bandera, R. Maag, A. Linden, K. K. Baldridge and J. S. Siegel, J. Am. Chem. Soc. 2008, 130, 10729-10739; b) T. J. Seiders, K. K. Baldridge, G. H. Grube and J. S. Siegel, J. Am. Chem. Soc. 2001, 123, 517-525; c) H. A. Reisch, M. S. Bratcher and L. T. Scott, Org. Lett. 2000, 2, 1427-1430; d) L. T. Scott, Pure Appl. Chem. 1996, 68, 291-300.

[39] D. Miyajima, K. Tashiro, F. Araoka, H. Takezoe, J. Kim, K. Kato, M. Takata and T. Aida, J. Am. Chem. Soc. 2009, 131, 44.

[40] a) B. Topolinski, B. M. Schmidt, S. Schwagerus, M. Kathan and D. Lentz, Eur. J. Inorg. Chem. 2014, 5391-5405; b) J. W. Facendola, M. Seifrid, J. Siegel, P. I. Djurovich and M. E. Thompson, Dalton Trans. 2015, 44, 8456-8466; c) R. Maag, B. H. Northrop, A. Butterfield, A. Linden, O. Zerbe, Y. M. Lee, K.-W. Chi, P. J. Stang and J. S. Siegel, Org. Biomol. Chem. 2009, 7, 4881-4885; d) P. A. Vecchi, C. M. Alvarez, A. Ellern, R. J. Angelici, A. Sygula, R. Sygula and P. W. Rabideau, Organometallics 2005, 24, 4543-4552; e) T. J. Seiders, K. K. Baldridge, J. M. Oconnor and J. S. Siegel, J. Am. Chem. Soc. 1997, 119, 47814782; f) J. S. Siegel, K. K. Baldridge, A. Linden and R. Dorta, J. Am. Chem. Soc. 2006, 128, 10644-10645; g) T. J. Seiders, K. K. Baldridge, J. M. O'Connor and J. S. Siegel, Chem. Commun. 2004, 950-951; h) C. M. Alvarez, L. A. GarciaEscudero, R. Garcia-Rodriguez, J. M. Martin-Alvarez, D. Miguel and V. M. Rayon, Dalton Trans. 2014, 43, 15693-15696.

[41] a) H. Yang, B. Yuan, X. Zhang and O. A. Scherman, Acc. Chem. Res. 2014, 47, 2106-2115; b) P. J. Altmann and A. Pothig, J. Am. Chem. Soc. 2016, 138, 1317113174.

[42] Y. Liu, H. Wang, P. Liang and H. Y. Zhang, Angew. Chem. Int. Ed. 2004, 43, 2690-2694.

[43] J. L. Atwood, G. A. Koutsantonis and C. L. Raston, Nature 1994, 368, 229-231.

[44] Y. B. Wang and Z. Y. Lin, J. Am. Chem. Soc. 2003, 125, 6072-6073.

[45] K. Tashiro, T. Aida, J. Y. Zheng, K. Kinbara, K. Saigo, S. Sakamoto and K. Yamaguchi, J. Am. Chem. Soc. 1999, 121, 9477-9478.

[46] D. Canevet, E. M. Perez and N. Martin, Angew. Chem. Int. Ed. 2011, 50, 92489259.

[47] H. W. Kroto, J. R. Heath, S. C. Obrien, R. F. Curl and R. E. Smalley, Nature 1985, 318, 162-163.

[48] A. Sygula, Synlett 2016, 27, 2070-2080. 



\section{Chapter 2}

Metal Complexes with Tris-NHC and Tris-MIC Ligands Based on a 1,3,5Triphenylbenzene Core 



\subsection{Introduction}

Highly symmetrical poly-N-heterocyclic carbene ligands (poly-NHCs) and their corresponding poly-metallic complexes have been subject of increasing attention because they allow the preparation of a wide variety of multifunctional materials. ${ }^{[1]}$ The design of architectures with geometrically isolated carbenes has allowed the development of NHC-based materials, ${ }^{[2]}$ which are potentially useful for the preparation of organometallic polymers with sensing, magnetic, optical, and catalytic properties. ${ }^{[2]}$ This special type of poly-carbenes may generate multimetallic catalysts that can find important applications, specially towards the design of sophisticated tandem catalytic processes. $^{[3]}$ Additionally, the catalytic activity of the multimetallic complexes can be compared with the activity of their related monometallic counter-parts, providing some insight into catalytic cooperativity between the metals comprised in the multimetallic systems. ${ }^{[4]}$
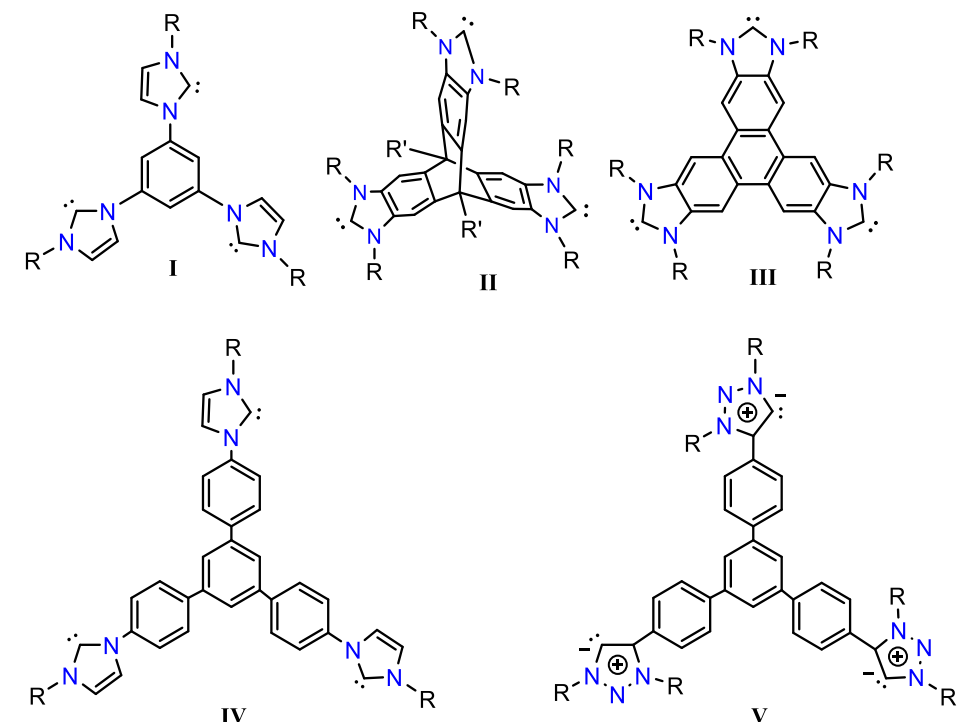

Chart 2.1. Representative examples of $C_{3}$-symmetry tris-carbene ligands

Chart 2.1 shows some known $C_{3}$-symmetry tris-carbenes (I-III) ${ }^{[5]}$ together with those that will be subject of study in this work (IV and $\mathbf{V}$ ). While $\mathbf{I}^{[6]}$ and $\mathbf{I I}^{[7]}$ display electronically disconnected carbenes, III $^{[4]}$ holds three carbenes connected through a $\pi$ delocalized polyaromatic system. However, studies on the electronic communication between the metals bound to III, demonstrated that the communication seems to be disrupted, ${ }^{[8]}$ probably due to the negligible $d_{M-} p_{L}$ overlap as a consequence of the lack of $\pi$-backdonation. It is worth mentioning that the tris-carbene III allowed the preparation of trimetallic catalysts, whose activities were significantly improved 
compared to their monometallic analogues in several benchmark homogeneously catalyzed reactions. ${ }^{[9]}$

Prompted by these previous findings, we decided to design a new type of $C_{3}$-symmetry ligands (IV and V), in which a 1,3,5-triphenylbenzene core connects all three carbene moieties. ${ }^{[10]}$ It is worth mentioning, that $\mathbf{V}$ constitutes an important development on MIC chemistry, because MICs were only very recently unveiled, ${ }^{[11]}$ and therefore, the development of MIC-based poly-metallic complexes is still in its infancy. Parallel to the preparation of trimetallic complexes with $C_{3}$-symmetry, we believe that both, IV and $\mathbf{V}$, could potentially be used for the preparation of novel supramolecular assemblies, as will be reflected in the following Chapters.

In addition, polyphenylenes have been subject of increasing attention due to their luminescence properties. ${ }^{[12]}$ In this context, symmetrically-trisubstituted benzenes

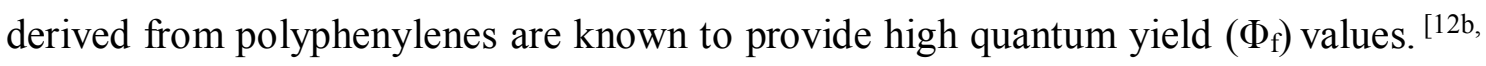
13] Herein, the study of the luminescence properties of new 1,3,5-triphenylbenzene based NHC ligands (IV) will be presented and discussed in the next section. Finally, this Chapter will describe the coordination studies of $\mathbf{I V}$ and $\mathbf{V}$ to $\mathrm{Rh}^{(\mathrm{I})}, \mathrm{Ir}^{(\mathrm{I})}$ and $\mathrm{Ni}^{(\mathrm{II})}$, together with some preliminary studies on their catalytic activities.

\subsection{Results and discussion}

\subsubsection{Synthesis and characterization of $C_{3}$-symmetry tris-azolium salts}

Chart 2.2 shows the tris-imidazolium and tris-triazolium salts that will be used as trisNHC and tris-MIC precursors all along this Chapter. As a common feature, both salts contain a 1,3,5-triphenylbenzene core.

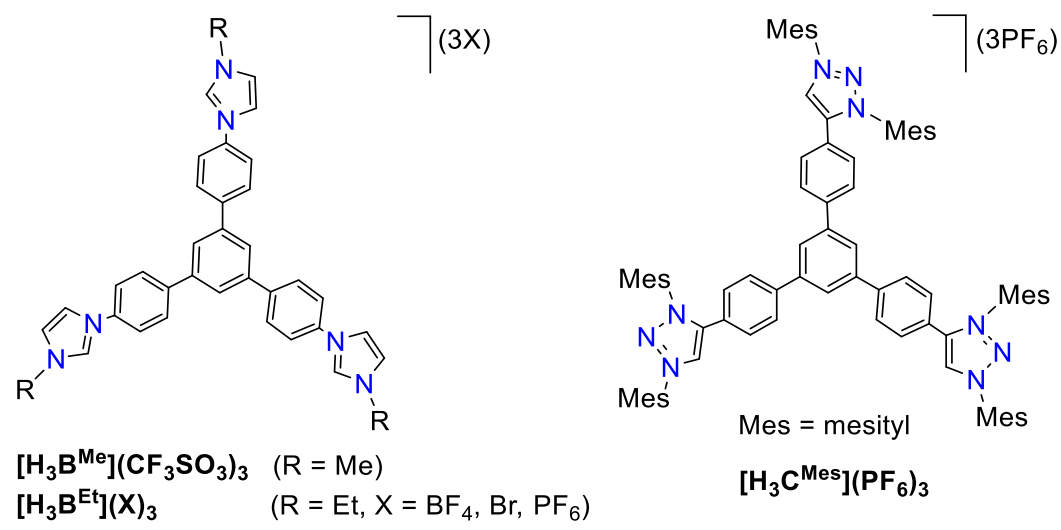

Chart 2.2. Tris-azolium salts 


\subsubsection{1 $C_{3}$-symmetry tris-imidazolium salts. Synthesis and characterization}

The tris-imidazolium salts were obtained by using the Ullmann C-C coupling reaction according to the synthetic procedure depicted in Scheme 2.1. This methodology has been described by Hahn and co-workers for the preparation of related 1,3,5-phenylenetris-imidazolium salts. ${ }^{[6,14]}$

The reaction of 1,3,5-tris(4-bromophenylbenzene) with imidazole in the presence of $\mathrm{CuSO}_{4}$ and $\mathrm{K}_{2} \mathrm{CO}_{3}$, afforded the corresponding 1,3,5-tris(4-bromophenylbenzene) compound, in $65 \%$ yield. Subsequent quaternization of the nitrogen atoms at the trisimidazole compound A using different alkylating agents (methyl triflate, triethyloxonium tetrafluoroborate or bromoethane), yielded the corresponding salts.

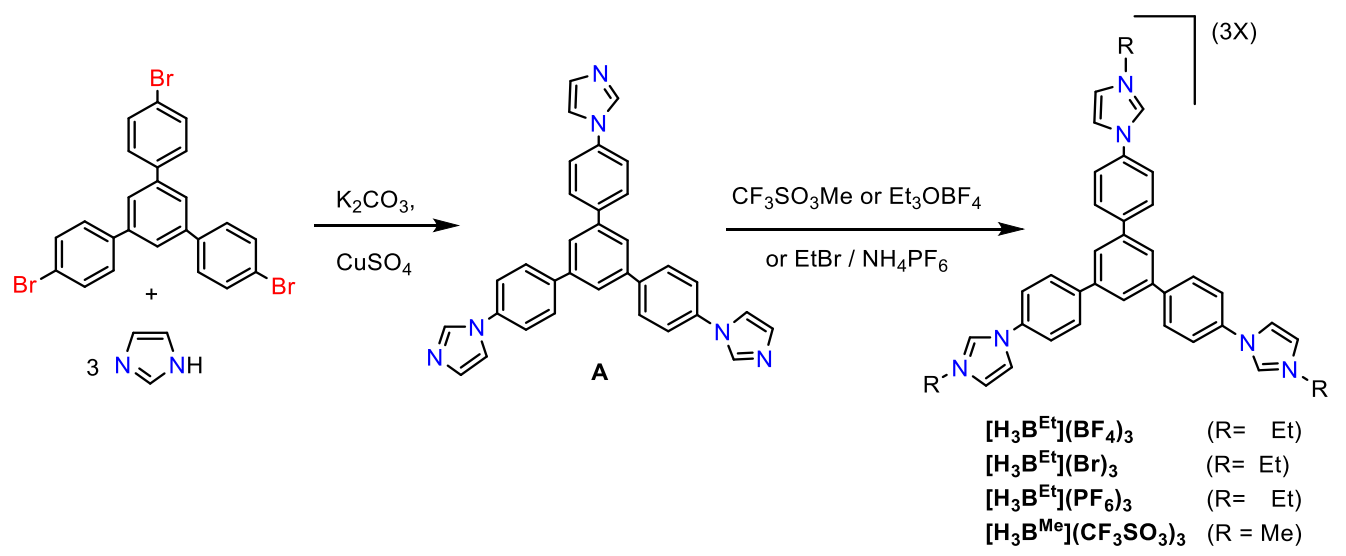

Scheme 2.1. Synthesis of tris-imidazolium salts

Compounds $\mathbf{A},\left[\mathrm{H}_{3} \mathrm{~B}^{\mathrm{Me}}\right]\left(\mathrm{CF}_{3} \mathrm{SO}_{3}\right)_{3}$ and $\left[\mathrm{H}_{3} \mathrm{~B}^{\mathrm{Et}}\right](\mathrm{X})_{3}$ were characterized by means of NMR spectroscopy, mass spectrometry and elemental analysis. A common feature of their NMR spectra is that they all are consistent with their predicted $C_{3}$-symmetry. As an illustrative example, the ${ }^{1} \mathrm{H}$ NMR spectrum of $\left[\mathbf{H}_{3} \mathbf{B}^{\mathrm{Me}}\right]\left(\mathrm{CF}_{3} \mathbf{S O}_{3}\right)_{3}$ is described below. For comparative purposes, the corresponding mono-imidazolium salt derivative $\left[\mathbf{H D}^{\mathrm{Et}}\right]\left(\mathbf{B F}_{4}\right)$, had also been synthesized. All details regarding the synthesis and spectroscopic features of compounds $A,\left[\mathbf{H}_{3} B^{\mathrm{Et}}\right]\left(\mathrm{BF}_{4}\right)_{3},\left[\mathrm{H}_{3} \mathbf{B}^{\mathrm{Et}}\right](\mathbf{B r})_{3},\left[\mathrm{H}_{3} B^{\mathrm{Et}}\right]\left(\mathbf{P F}_{6}\right)_{3}$ and $\left[\mathbf{H D}^{\mathrm{Et}}\right]\left(\mathbf{B F}_{4}\right)$ can be found in the Experimental Section (Chapter 5). 


\section{${ }^{1} \mathrm{H} N M R$ spectrum of $\left[\mathrm{H}_{3} \mathrm{~B}^{\mathrm{Me}}\right]\left(\mathrm{CF}_{3} \mathrm{SO}_{3}\right)_{3}$}

Figure 2.1 shows ${ }^{1} \mathrm{H}$ NMR spectrum of $\left[\mathbf{H}_{3} \mathbf{B}^{\mathbf{M e}}\right]\left(\mathbf{C F}_{3} \mathbf{S O}_{3}\right)_{3}$. The number of signals and their integration are consistent with the $C_{3}$-symmetry of the molecule. The signal due to the acidic protons from the NCHN group (a) is displayed as a singlet at $9.52 \mathrm{ppm}$. The signals corresponding to the protons of 1,3,5-triphenylbenzene core (d, e and $\mathbf{f})$ along with the protons of the imidazole ring (b) are displayed between 8.12-7.81 ppm. Finally, the signal due to the protons of the three methyl groups appears at $4.08 \mathrm{ppm}(\mathbf{c})$.

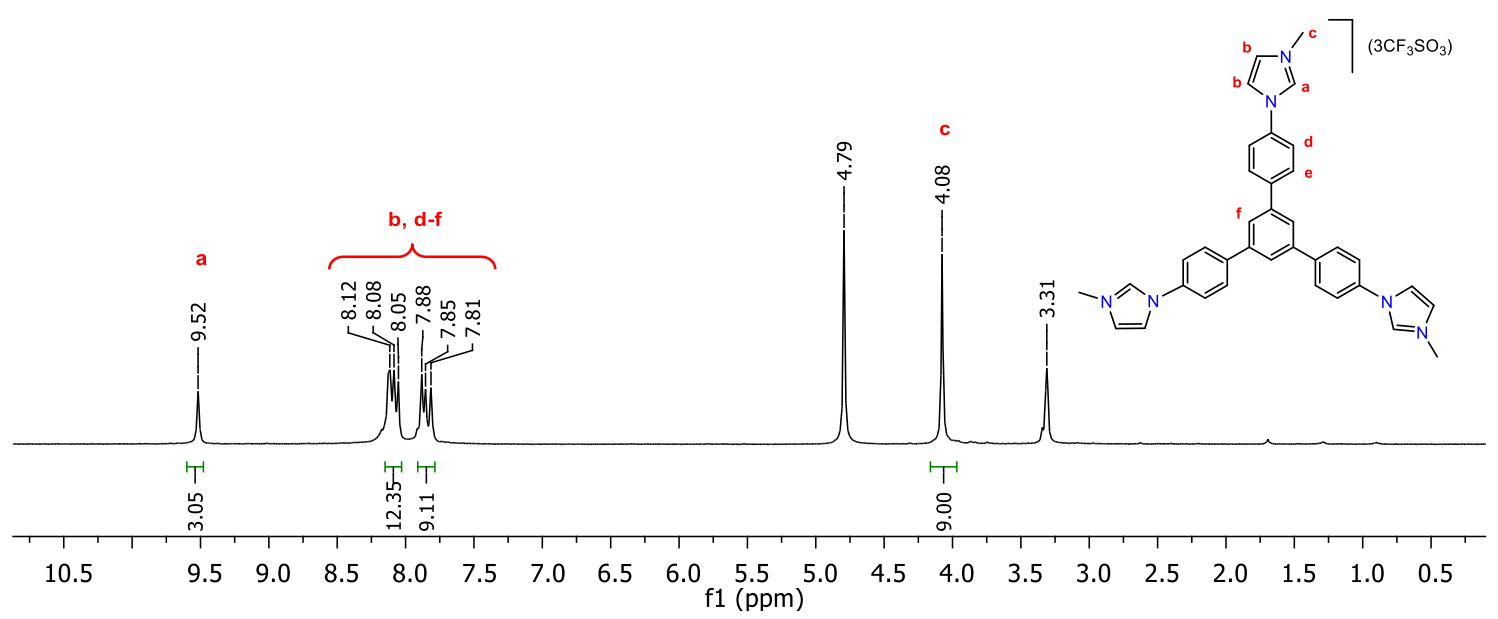

Figure 2.1. ${ }^{1} \mathrm{H}$ NMR spectrum of $\left[\mathrm{H}_{3} \mathrm{~B}^{\mathrm{Me}}\right]\left(\mathrm{CF}_{3} \mathrm{SO}_{3}\right)_{3}$ in $\mathrm{CD}_{3} \mathrm{OD}$

\section{Molecular structure of $\left[\mathrm{H}_{3} \mathrm{~B}^{\mathrm{Me}}\right]\left(\mathrm{CF}_{3} \mathrm{SO}_{3}\right)_{3}$}

Crystals of $\left[\mathrm{H}_{3} \mathrm{~B}^{\mathrm{Me}}\right]\left(\mathrm{CF}_{3} \mathrm{SO}_{3}\right)_{3}$ suitable for X-Ray Diffraction analysis were obtained by slow diffusion of diethyl ether into a concentrated solution of the salt in $\mathrm{MeOH}$.

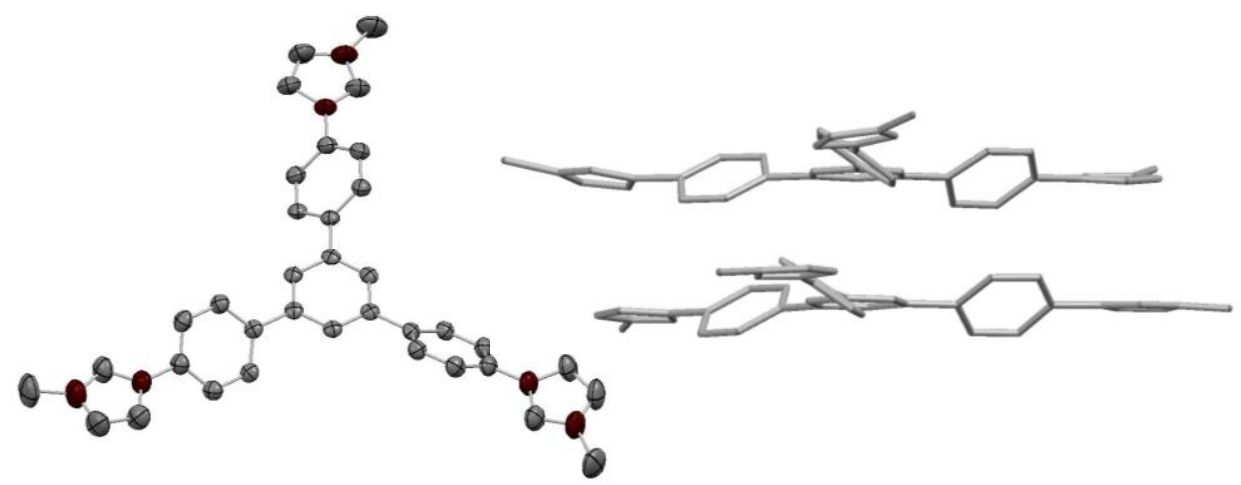

Figure 2.2. Molecular structure of $\left[\mathbf{H}_{3} \mathbf{B}^{\mathrm{Me}}\right]\left(\mathrm{CF}_{3} \mathrm{SO}_{3}\right)_{3}$ (left). Hydrogen atoms and counterions $\left(\mathrm{CF}_{3} \mathrm{SO}_{3}{ }^{-}\right)$ have been omitted for clarity. Ellipsoids at $50 \%$ of probability. The figure on the right shows the $\pi$ stacking of two adjacent molecules 
The molecular structure of $\left[\mathbf{H}_{3} \mathbf{B}^{\mathrm{Me}}\right]\left(\mathrm{CF}_{3} \mathbf{S O}_{3}\right)_{3}$, shown Figure 2.2, confirms the presence of the three imidazole rings connected to the tris-phenylbenzene core.

The crystal packing shows a one-dimensional $\pi$-stacking involving all four phenylene rings of each molecule separated by $3.605 \AA$. Although the molecule is not co-planar, the relative disposition of adjacent tris-imidazolium moieties shows that all aromatic rings are displayed in a quasi-parallel manner.

\subsubsection{2 $C_{3}$-symmetry tris-triazolium salt. Synthesis and characterization}

For comparative purposes we also aimed to prepare a 1,3,5-triphenylbenzene-based tristriazolium salt, in order to gain further insights into the features of these systems.

The tris-triazolium salt $\left[\mathbf{H}_{3} \mathbf{C}^{\mathbf{M e s}}\right]\left(\mathbf{P F}_{\mathbf{6}}\right)_{3}$ was obtained in $93 \%$ yield, by following the procedure depicted in Scheme 2.2. The reaction of 1,3,5-tris(4ethynylphenylbenzene $)^{[15]}$ with 1,3-dimesityltriazene ${ }^{[11 \mathrm{c}]}$ in the presence of $\mathrm{KPF}_{6}$ and ${ }^{t} \mathrm{BuOCl}$ at $-78^{\circ} \mathrm{C}$, afforded the corresponding 1,3,5-triphenylbenzene-bridged tris-1,3diaryl-1H-1,2,3-triazolium tris(hexafluorophosphate). This tris-triazolium salt was characterized by means of NMR and mass spectrometry and elemental analysis. The ${ }^{1} \mathrm{H}$ and ${ }^{13} \mathrm{C}\left\{{ }^{1} \mathrm{H}\right\}$ NMR spectra of $\left[\mathbf{H}_{3} \mathbf{C}^{\text {Mes }}\right]\left(\mathbf{P F}_{\mathbf{6}}\right)_{3}$ confirmed the threefold symmetry of the molecule.

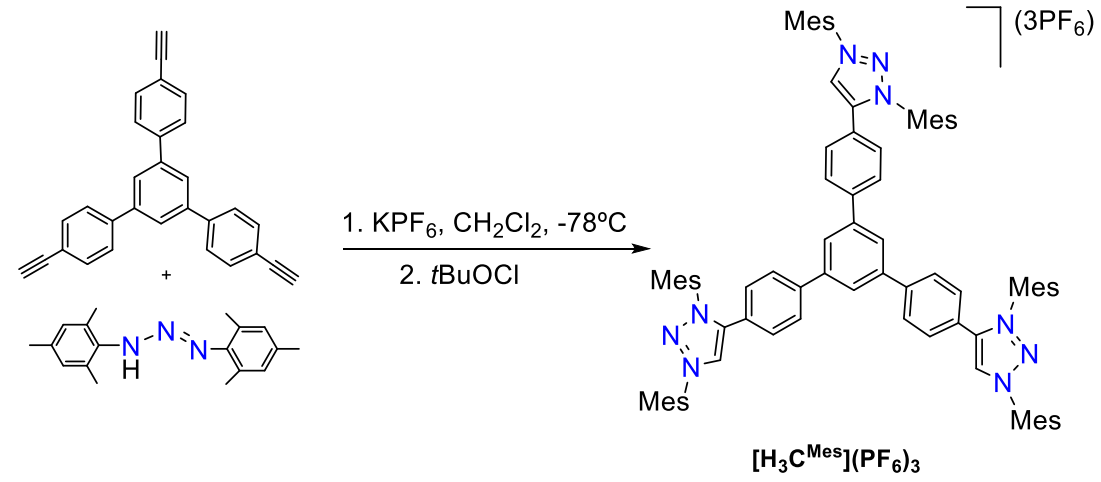

Scheme 2.2. Synthesis of tris-triazolium salts $\left[\mathrm{H}_{3} \mathrm{C}^{\mathrm{Mes}}\right]\left(\mathrm{PF}_{6}\right)_{3}$

\section{${ }^{1} \mathrm{H} N M R$ spectrum of $\left[\mathrm{H}_{3} \boldsymbol{C}^{\mathrm{Mes}}\right]\left(\boldsymbol{P F}_{\mathbf{6}}\right)_{3}$}

Figure 2.3 shows the ${ }^{1} \mathrm{H}$ NMR spectrum of $\left[\mathbf{H}_{3} \mathbf{C}^{\mathbf{M e s}}\right]\left(\mathbf{P F}_{\mathbf{6}}\right)_{3}$. The number of signals and their integration are consistent, with the $C_{3}$-symmetry of the molecule, as previously observed for the imidazolium salts. The signal due to the acidic protons from the $\mathrm{NC}(H) \mathrm{N}$ group (a) is displayed at $9.08 \mathrm{ppm}$. The signals assigned to the protons of the 1,3,5-triphenylbenzene core (e, $\mathbf{f}$ and $\mathbf{g}$ ) are displayed between 7.78-7.58 ppm, and the signals for the aromatic protons of the mesityl groups (d) are shown at 7.13-7.15 ppm. 
Finally, the signals due to the protons of the methyl groups at the mesityl groups appear between 2.43 and $2.06 \mathrm{ppm}(\mathbf{b}$ and $\mathbf{c})$.

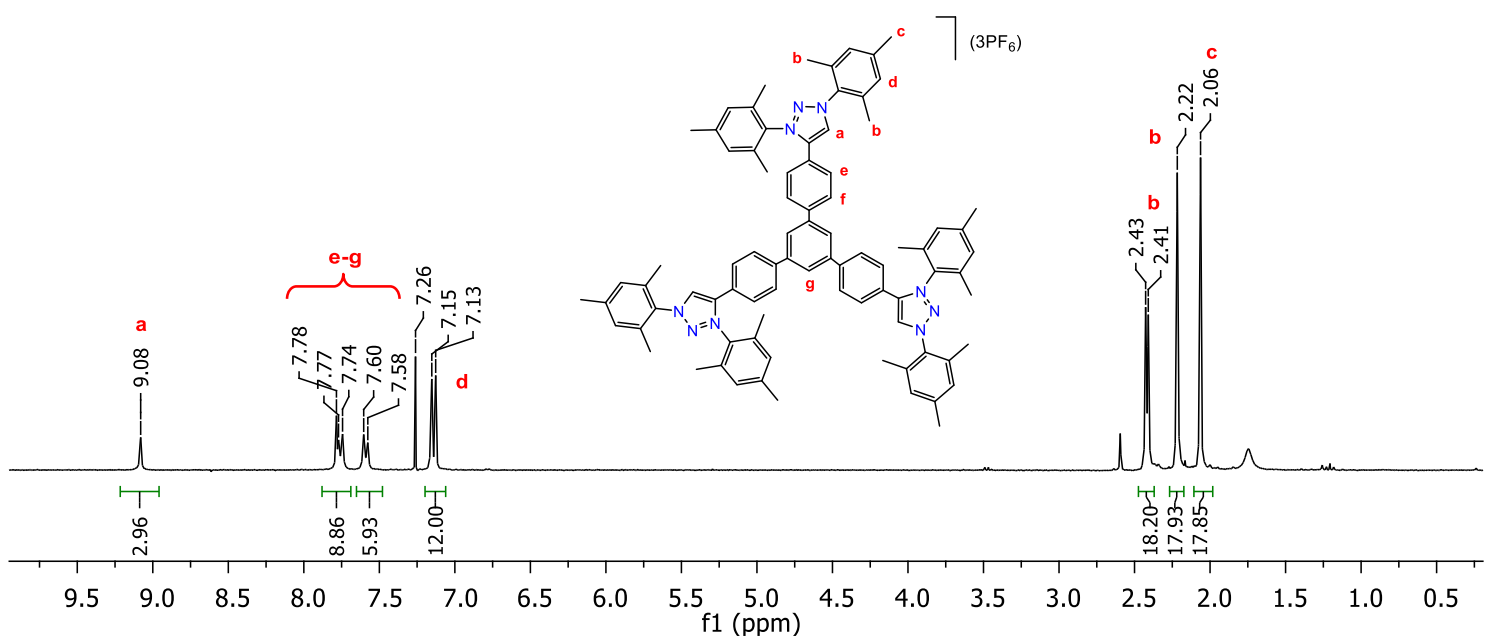

Figure 2.3. ${ }^{1} \mathrm{H}$ NMR spectrum of $\left[\mathbf{H}_{3} \mathbf{C}^{\mathrm{Mes}}\right]\left(\mathbf{P F}_{6}\right)_{3}$ in $\mathrm{CDCl}_{3}$

\subsubsection{Luminescence properties of the tris-imidazolium salts}

Polyaromatic symmetrical cyclotrimers are often highly emissive. ${ }^{[12]}$ In fact, 1,3,5tris(4-bromophenylbenzene) possesses the highest quantum yields $(\Phi)$ in comparison with other benzenes bearing different number of phenyl substituents and located at different positions, and therefore constitutes an excellent scaffold for the design of luminiscent materials. ${ }^{[12 \mathrm{a}]}$ We considered that it could be interesting to evaluate the photophysical changes produced by the incorporation of three imidazolium rings into the 1,3,5-triphenylbenzene core.

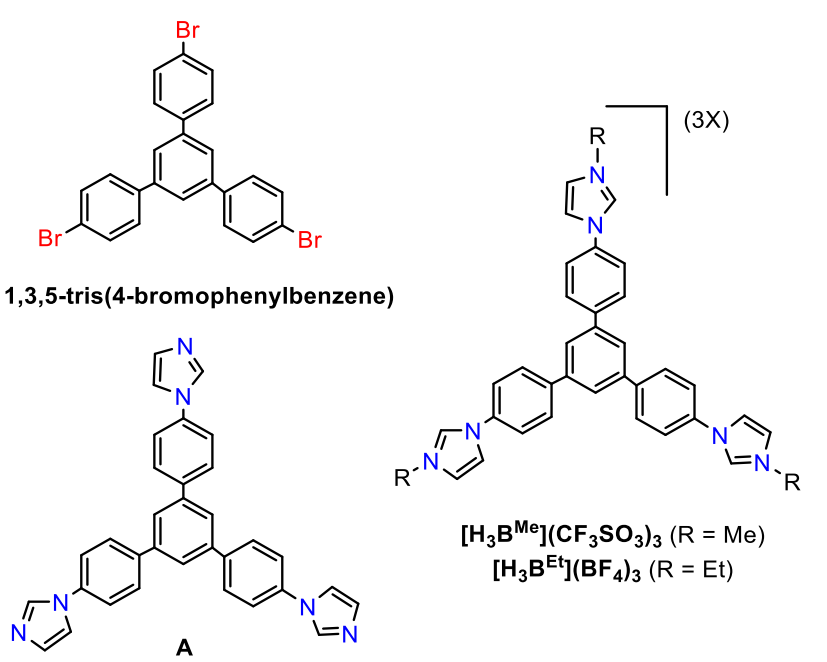

Chart 2.3. Polyaromatic systems under study 
Table 2.1 summarizes the photochemical properties of the polyaromatic systems shown in Chart 2.3. The complete set of UV-Vis and fluorescence spectra of these compounds can be found in the Experimental Section (Chapter 5).

Table 2.1. Luminescence properties of $\mathbf{A},\left[\mathbf{H}_{3} \mathbf{B}^{\mathrm{Me}}\right]\left(\mathrm{CF}_{3} \mathbf{S O}_{3}\right)_{3}$ and $\left[\mathrm{H}_{3} \mathbf{B}^{\mathrm{Et}}\right]\left(\mathrm{BF}_{4}\right)_{3}$

\begin{tabular}{ccccc}
\hline Entry & Compound & $\begin{array}{c}\lambda_{\mathrm{abs}}(\mathrm{nm}) \\
(\log (\varepsilon))^{\mathrm{a}}\end{array}$ & $\lambda_{\mathrm{em}}(\mathrm{nm})^{\mathrm{b}}$ & $\Phi_{\mathrm{f}}^{\mathrm{b}}$ \\
\hline $1^{\mathrm{c}}$ & $\begin{array}{c}\mathbf{1 , 3 , 5 - t r i s ( 4 -} \\
\text { bromophenylbenzene) }\end{array}$ & $253(4.71)$ & 352 & 0.29 \\
2 & $\mathbf{A}$ & $276(4.83)$ & 359 & 0.24 \\
3 & {$\left[\mathbf{H}_{3} \mathbf{B}^{\mathrm{Me}}\right]\left(\mathbf{C F}_{3} \mathbf{S O}_{3}\right)_{3}$} & $268(5.04)$ & 351 & 0.16 \\
4 & {$\left[\mathbf{H}_{\mathbf{3}} \mathbf{B}^{\mathrm{Et}}\right]\left(\mathbf{B F}_{4}\right)_{3}$} & $272(5.00)$ & 358 & 0.18 \\
\hline
\end{tabular}

${ }^{\mathrm{a}}$ Measurements performed in degassed $\mathrm{MeCN}$ under ambient conditions. Molar extinction coefficients $(\varepsilon$, in $\mathrm{M}^{-1} \mathrm{~cm}^{-1}$ ) were determined from Beer's law plots. ${ }^{b}$ Emission quantum yield was determined using as standard a $1 \mathrm{~N}$ solution of quinine bisulfate in degassed $\mathrm{H}_{2} \mathrm{SO}_{4}\left(\Phi_{\mathrm{f}}=0.55\right)$ exciting at $290 \mathrm{~nm}$. ${ }^{c}$ Values taken from reference ${ }^{[12 a]}$

All three compounds $\mathrm{A},\left[\mathbf{H}_{3} \mathbf{B}^{\mathrm{Me}}\right]\left(\mathrm{CF}_{3} \mathbf{S O}_{3}\right)_{3}$ and $\left[\mathbf{H}_{3} \mathbf{B}^{\mathrm{Et}}\right]\left(\mathrm{BF}_{4}\right)_{3}$ exhibit fluorescence emission in the $320-420 \mathrm{~nm}$ region, although their quantum yields are moderate $(0.16$ 0.24). From the data given in Table 2.1, it can be observed that the cationic species $\left[\mathbf{H}_{3} \mathbf{B}^{\mathrm{Me}}\right]^{3+}$ and $\left[\mathbf{H}_{3} \mathbf{B}^{\mathrm{Et}}\right]^{3+}$ show similar quantum yields, and similar emission maximum wavelengths compared those of the neutral compound A. Furthermore, the absorption and emission properties are comparable to those provided by 1,3,5-tris(4bromophenylbenzene) (entry 1). The fact that the photophysical properties of the trisimidazolium molecules are maintained compared to those provided by triphenylbenzene, may be considered as an advantage, if we take into account that the production of highly stable tri-cationic molecules such as $\left[\mathbf{H}_{3} \mathbf{B}^{\mathrm{Me}}\right]^{3+}$ and $\left[\mathbf{H}_{3} \mathbf{B}^{\mathrm{Et}}\right]^{3+}$ may give rise to molecules with tuneable physical properties such as solubility, or melting point, just by modifying the nature of the counter-anion and the $\mathrm{N}$-substituents at the imidazole rings.

\subsubsection{Synthesis and characterization of trimetallic complexes}

A series of $\mathrm{Rh}^{(\mathrm{I})}, \mathrm{Ir}^{(\mathrm{I})}$ and $\mathrm{Ni}^{(\mathrm{II})}$ complexes (see Chart 2.4) were prepared employing different metallation strategies depending on the metal precursors used. In the following 
sections, the preparation and characterization of the complexes obtained will be explained in detail.

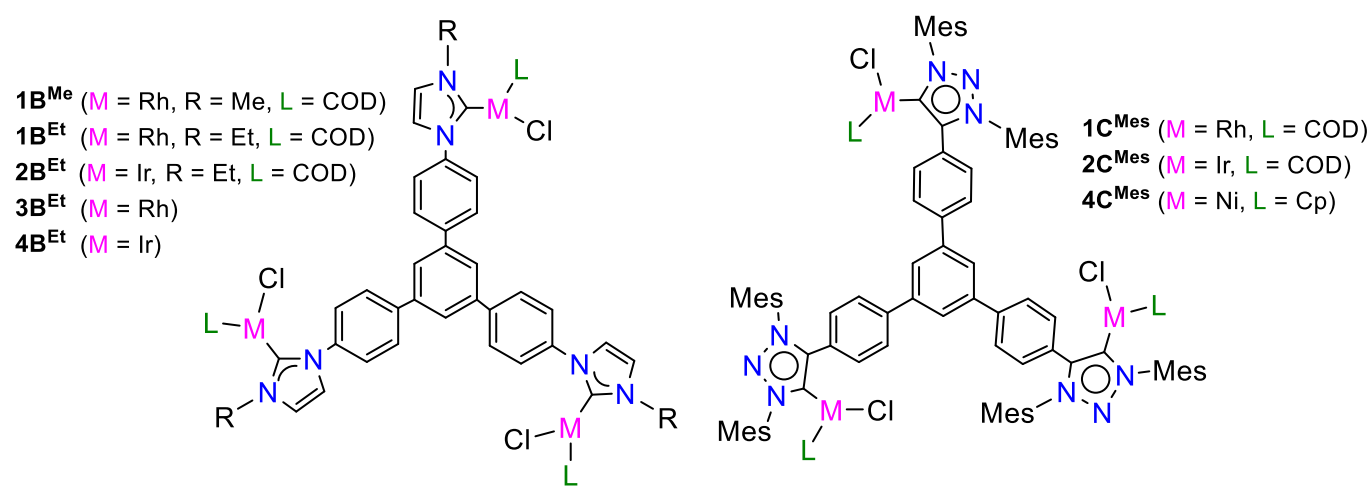

Chart 2.4. Tris-azolium complexes

\subsubsection{Iridium(I) and rhodium(I) complexes}

In this section, we will describe the coordination capabilities of the ligand starting from the tris-azolium salts previously described. By using $[\mathrm{MCl}(\mathrm{COD})]_{2}(\mathrm{M}=\mathrm{Rh}$ or $\mathrm{Ir})$ as metal precursors, we aimed to obtain the corresponding trimetallic complexes. In general, the reaction of the corresponding salt (tris-triazolium or tris-imidazolium) with $[\mathrm{MCl}(\mathrm{COD})]_{2}(\mathrm{M}=\mathrm{Rh}$ or $\mathrm{Ir})$ in presence of a base, allowed the preparation of all our complexes in moderate to good yields. Then, these complexes can be transformed into their corresponding carbonyl derivatives by bubbling $\mathrm{CO}$ through a solution of these metal complexes in methylene chloride.

\section{Complexes with NHC ligands}

The deprotonation of $\left[\mathbf{H}_{3} \mathbf{B}^{\mathrm{Et}}\right]\left(\mathbf{B F}_{4}\right)_{3} \quad$ (or $\left.\left[\mathbf{H}_{3} \mathbf{B}^{\mathrm{Me}}\right]\left(\mathbf{C F}_{3} \mathbf{S O}_{3}\right)_{3}\right)$ with potassium bis(trimethyl)silylamide (KHMDS) in THF, followed by the addition of [MCl(COD) $]_{2}$ $(\mathrm{M}=\mathrm{Rh}, \mathrm{Ir})$, allowed the preparation of the corresponding tris-NHC complexes of rhodium $\left(\mathbf{1} \mathbf{B}^{\mathrm{Me}}\right.$ or $\left.\mathbf{1 B}^{\mathrm{Et}}\right)$ and iridium $\left(\mathbf{2 B}^{\mathrm{Et}}\right)$ (Scheme 2.3). 


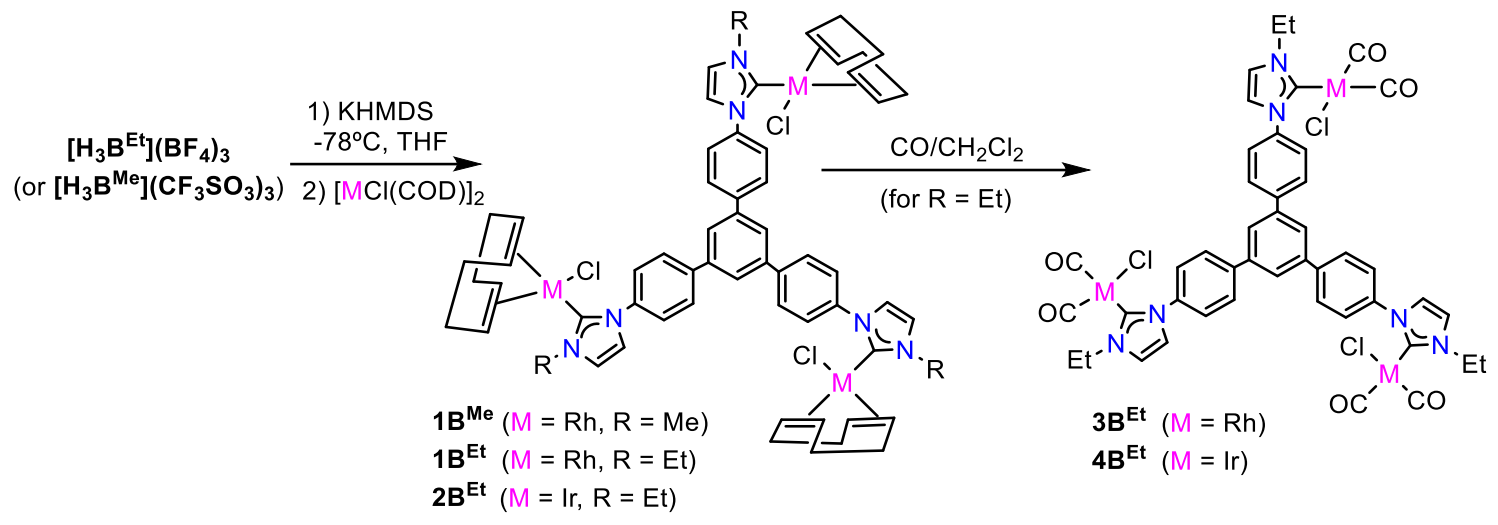

Scheme 2.3.Preparation of the metal complexes

Compounds $\mathbf{1} \mathbf{B}^{\mathrm{Et}}$ and $\mathbf{2} \mathbf{B}^{\mathrm{Et}}$ were converted into their corresponding carbonyl derivatives by bubbling $\mathrm{CO}$ through a solution of these complexes in methylene chloride at $0{ }^{\circ} \mathrm{C}$. Precipitation from a mixture $\mathrm{CH}_{2} \mathrm{Cl}_{2}$ /hexane afforded the desired carbonylated compounds, $\mathbf{3 B}^{\mathrm{Et}}$ and $\mathbf{4} \mathbf{B}^{\mathrm{Et}}$, in excellent yields $\left(90 \%\right.$ for $\mathbf{3} \mathbf{B}^{\mathrm{Et}}$ and $87 \%$ for $\left.\mathbf{4} \mathbf{B}^{\mathrm{Et}}\right)$.

All new trimetallic complexes were characterized by NMR spectroscopy, mass spectrometry and elemental analysis. Due to the similarity between these compounds, only the ${ }^{1} \mathrm{H}$ NMR spectrum of $\mathbf{1 B}^{\mathrm{Et}}$ will be described below. All the details regarding the characterization of all other complexes, including the two monometallic $\mathrm{Rh}^{(\mathrm{I})}$ and $\operatorname{Ir}^{(\mathrm{I})}$ derivatives $\mathbf{1 D}^{\mathrm{Et}}$ and $\mathbf{2} \mathbf{D}^{\mathbf{E t}}$ respectively, can be found in the Experimental Section (Chapter 5).

As a common feature, the ${ }^{1} \mathrm{H}$ and ${ }^{13} \mathrm{C}\left\{{ }^{1} \mathrm{H}\right\}$ NMR spectra of these new complexes, are in agreement with their predicted threefold symmetry. For example, the ${ }^{1} \mathrm{H}$ NMR spectra of all complexes display two sharp signals assigned to the protons of the backbone of the three equivalent imidazolylidene rings. The ${ }^{13} \mathrm{C}\left\{{ }^{1} \mathrm{H}\right\}$ NMR spectra show single resonances due to the metallated carbene carbons, with the distinctive ${ }^{1} J_{\mathrm{Rh}-\mathrm{C}}$ couplings for the case of the rhodium complexes (1B ${ }^{\mathbf{M e}}$ : $183.8 \mathrm{ppm},{ }^{1} J_{\mathrm{Rh}-\mathrm{C}}=51.2 \mathrm{~Hz} ; \mathbf{1 B}^{\mathrm{Et}}$ : 182.9

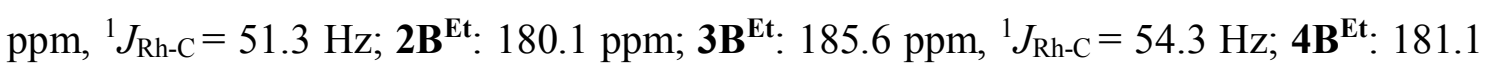
ppm). As illustrative examples, the ${ }^{1} \mathrm{H}$ and ${ }^{13} \mathrm{C}\left\{{ }^{1} \mathrm{H}\right\}$ NMR spectra of $\mathbf{1 B}{ }^{\mathbf{E t}}$ are described below.

\section{${ }^{1} H$ NMR spectrum of $1 B^{E t}$}

Figure 2.4 shows the ${ }^{1} \mathrm{H}$ NMR spectrum of $\mathbf{1} \mathbf{B}^{\mathrm{Et}}$. The absence of the signal due to the acidic protons of the $\mathrm{NCHN}$ groups is the first indication of the coordination of the 
triphenylene-based tris-imidazolylidene ligand to $\mathrm{RhCl}(\mathrm{COD})$. The signals corresponding to the protons of the 1,3,5-triphenylbenzene scaffold (d, e and $\mathbf{f})$ appear at $8.39,7.96$ and $7.25 \mathrm{ppm}$, respectively. The signals attributed to the protons of the $\mathrm{CH}$ groups of the imidazolylidenes are shown as two doublets at 7.94 and $7.06 \mathrm{ppm}(\mathbf{a})$. The signals due to the protons of the tree ethyl groups appear at 4.78 and $1.66 \mathrm{ppm}$ (b and $\mathbf{c}$, respectively). The rest of the signals corresponding to the protons of the COD ligands are directly displayed on the spectrum.

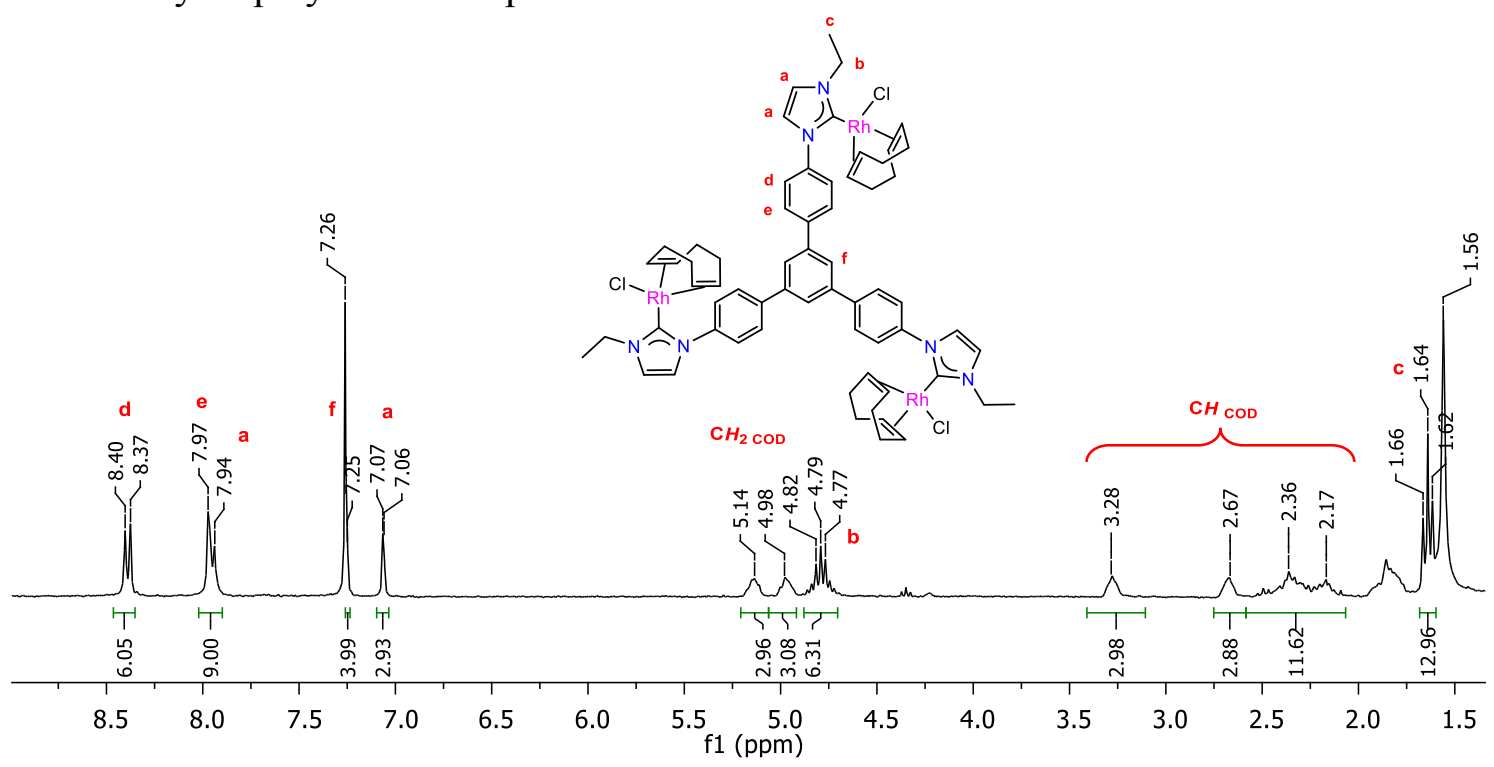

Figure 2.4. ${ }^{1} \mathrm{H}$ NMR spectrum of $1 \mathbf{B}^{\mathrm{Et}}$ in $\mathrm{CDCl}_{3}$

\section{${ }^{13} C\left\{{ }^{1} H\right\}$ NMR spectrum of $\mathbf{1 B} \boldsymbol{B}^{E t}$}

Figure 2.5 shows the ${ }^{13} \mathrm{C}\left\{{ }^{1} \mathrm{H}\right\}$ NMR spectrum of $1 \mathbf{B}^{\mathrm{Et}}$. The most characteristic signal is that attributed to the metallated carbene-carbon (1), which is displayed as a doublet at $182.9 \mathrm{ppm}\left({ }^{1} J_{\mathrm{Rh}-\mathrm{C}}=51.3 \mathrm{~Hz}\right)$.

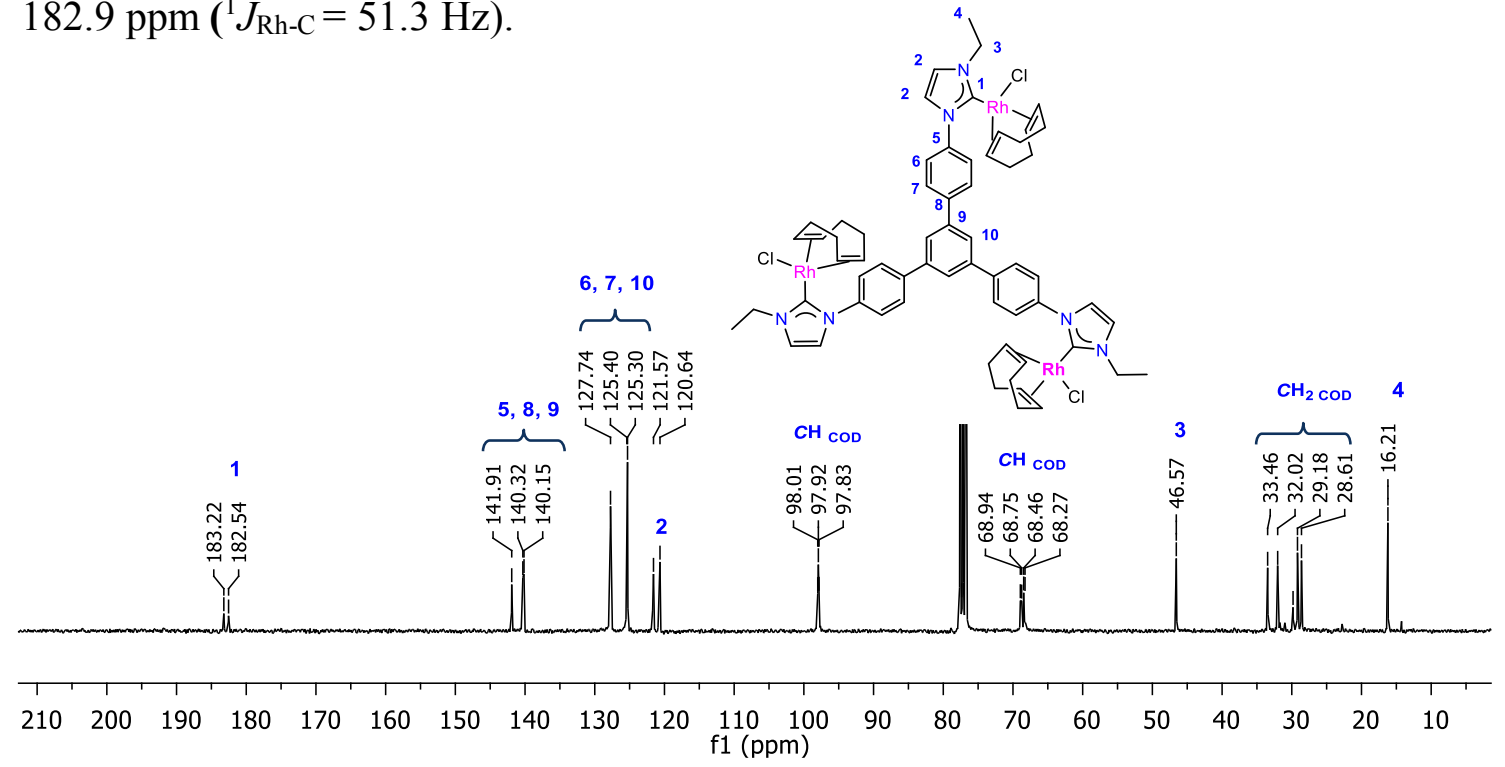

Figure 2.5. ${ }^{13} \mathrm{C}\left\{{ }^{1} \mathrm{H}\right\}$ NMR spectrum of $\mathbf{1 B}^{\mathrm{Et}}$ in $\mathrm{CDCl}_{3}$ 
The signals corresponding to the carbons from the $\mathrm{CH}$ groups of the imidazolylidene rings (2) appear at 121.6 and $120.6 \mathrm{ppm}$. The signals attributed to the 1,3,5triphenylbenzene core are displayed between 140.9-120.6 ppm. The signals due to the carbons of the three ethyl groups appear at 46.6 and $16.2 \mathrm{ppm}$ (3 and 4, respectively). The rest of the signals corresponding to the carbon atoms of the COD ligands are conveniently displayed on the spectrum.

Although we tried our best to get single crystals suitable for the X-ray determination of the molecular structures of any of the trimetallic structures, all our attempts were in vain. In contrast, crystals suitable for X-ray analysis of the monometallic derivative 1D $^{\mathrm{Et}}$ were obtained.

\section{Molecular Structure of $\mathbf{1 D}^{\mathrm{Et}}$}

The molecular diagram of the rhodium complex $\mathbf{1 D}^{\mathbf{E t}}$, bearing a 1-phenyl-3-ethylimidazolylidene (Figure 2.6) is interesting because it represents the expected local molecular geometry of each of the metal fragments in the related trimetallic complex $\mathbf{1 B}^{\mathbf{E t}}$. The details of the preparation of this complex can be found in the Experimental Section, Chapter 5.

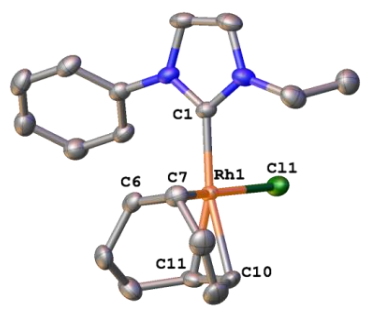

Figure 2.6. Molecular diagram of complex $\mathbf{1 D}^{\mathrm{Et}}$. Ellipsoids at 50\% probability level. Hydrogens omitted for clarity.

The molecular structure consists of a NHC ligand bound to a $\mathrm{Rh}(\mathrm{I})$ center, which is completing its coordination sphere with a chloride and a COD ligand. The $\mathrm{Rh}-\mathrm{C}_{\text {carbene }}$ bond distance is 2.033(2) $\AA$ (see Table 2.2). The high trans influence of the NHC ligand is illustrated by the longer distance between the rhodium atom and the olefin in the trans position related to the NHC ligand (compare $2.195 \AA$ for the average Rh-C distances of the olefinic carbons trans to the NHC, with the $2.103 \AA$ for the average distance between $\mathrm{Rh}$ and the carbons of the olefin trans to $\mathrm{Cl}$ ). 
Table 2.2. Selected bond lengths and angles of complex $\mathbf{1 D}^{\mathbf{E t}}$

\begin{tabular}{lllr}
\hline \multicolumn{2}{c}{ Bond lengths $(\AA)$} & \multicolumn{2}{c}{ Bond angles $\left(^{\circ}\right)$} \\
\hline $\mathrm{Rh}(1)-\mathrm{C}(1)$ & $2.023(2)$ & $\mathrm{C}(1)-\mathrm{Rh}(1)-\mathrm{Cl}(1)$ & $88.47(6)$ \\
$\mathrm{Rh}(1)-\mathrm{Cl}(1)$ & $2.382(6)$ & $\mathrm{C}(1)-\mathrm{Rh}(1)-\mathrm{C}(7)$ & $89.42(8)$ \\
$\mathrm{Rh}(1)-\mathrm{C}(7)$ & $2.099(2)$ & $\mathrm{C}(1)-\mathrm{Rh}(1)-\mathrm{C}(10)$ & $161.99(10)$ \\
$\mathrm{Rh}(1)-\mathrm{C}(6)$ & $2.105(2)$ & & \\
$\mathrm{Rh}(1)-\mathrm{C}(10)$ & $2.208(2)$ & & \\
\hline
\end{tabular}

\section{Complexes with MIC ligands}

The synthesis of the MIC-based complex $\mathbf{1} \mathbf{C}^{\text {Mes }}$, was carried out following the same methodology employed for the synthesis of $\mathbf{1} \mathbf{B}^{\mathrm{Et}}$, which involves the deprotonation of the tris-triazolium salt $\left[\mathbf{H}_{3} \mathbf{C}^{\text {Mes }}\right]\left(\mathbf{P F}_{\mathbf{6}}\right)_{3}$ with potassium bis(trimethyl)silylamide (KHMDS) in THF, followed by the addition of $[\mathrm{RhCl}(\mathrm{COD})]_{2}$.

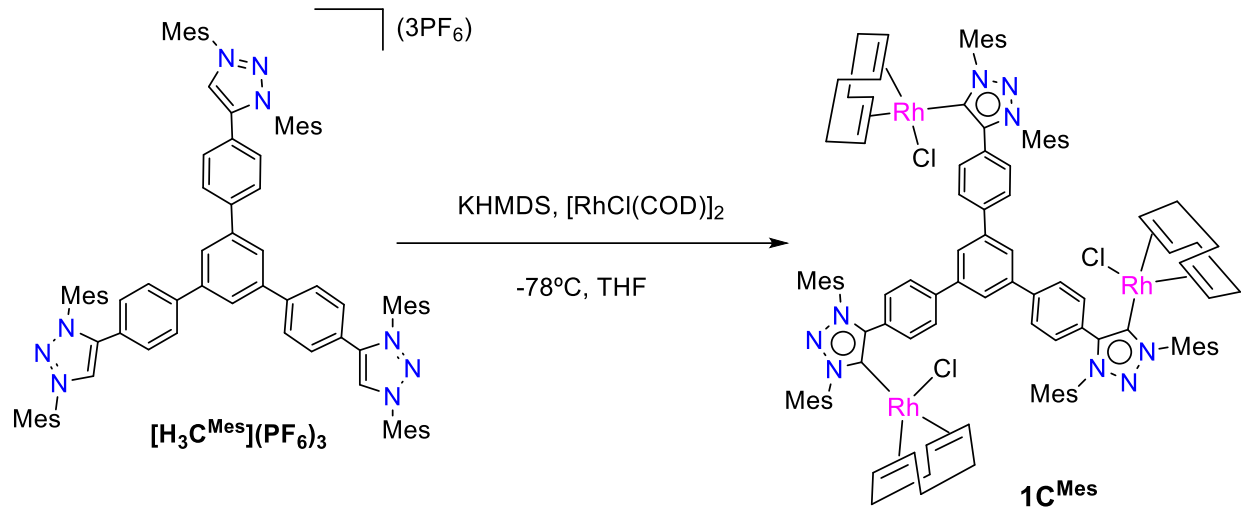

Scheme 2.4. Synthesis of $\mathbf{1 C}^{\mathrm{Mes}}$

In the case of $\mathbf{2} \mathbf{C}^{\text {Mes }}$, an alternative synthetic strategy was followed. The tris-triazolium salt $\left[\mathbf{H}_{3} \mathbf{C}^{\text {Mes }}\right]\left(\mathbf{P F}_{6}\right)_{3}$ was deprotonated in acetone using $\mathrm{K}_{2} \mathrm{CO}_{3}$ in the presence of $[\mathrm{IrCl}(\mathrm{COD})]_{2}$ under reflux (see Scheme 2.5).

Compound $1 \mathbf{C}^{\text {Mes }}$ can be easily transformed into the corresponding carbonyl derivative by bubbling $\mathrm{CO}$ through a solution of this complex in dichloromethane at $0^{\circ} \mathrm{C}$. Precipitation from a mixture $\mathrm{CH}_{2} \mathrm{Cl}_{2}$ hexane afforded the desired carbonylated compound $\mathbf{3} \mathrm{C}^{\text {Mes }}$ in excellent yield. 


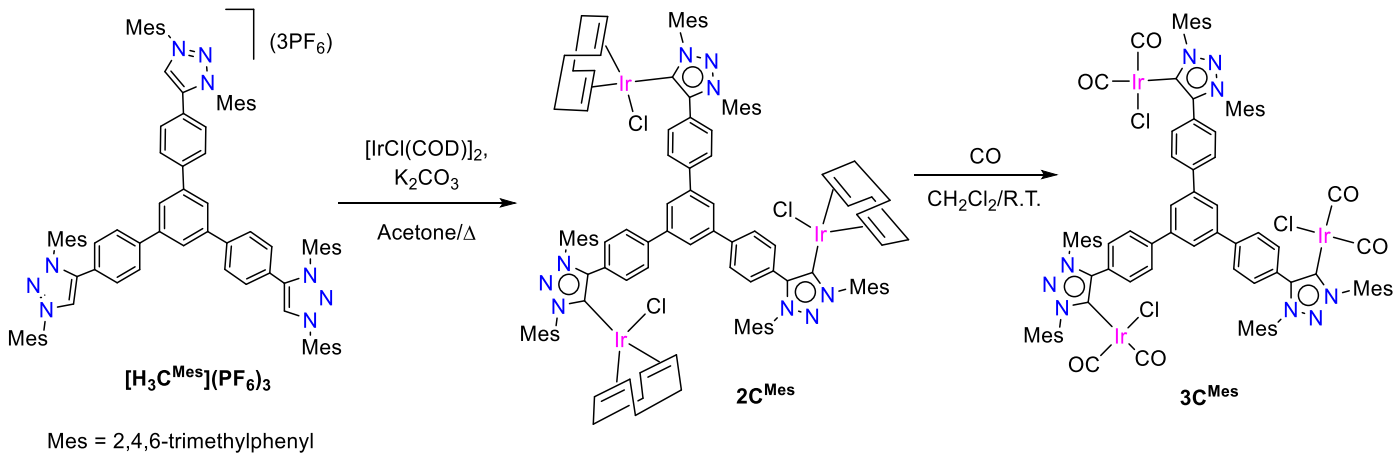

Scheme 2.5. Synthesis of $2 \mathrm{C}^{\text {Mes }}$ and $3 \mathrm{C}^{\text {Mes }}$

All new trimetallic complexes were characterized by NMR spectroscopy, mass spectrometry and elemental analysis. The ${ }^{1} \mathrm{H}$ and ${ }^{13} \mathrm{C}\left\{{ }^{1} \mathrm{H}\right\}$ NMR spectra of these new complexes, are consistent with their predicted threefold symmetries. For example, two sharp signals assigned to the protons of the backbone of the three equivalent imidazolylidene rings are observed in the ${ }^{1} \mathrm{H}$ NMR spectra. A single resonance due to the metallated carbene carbons is found in the ${ }^{13} \mathrm{C}\left\{{ }^{1} \mathrm{H}\right\}$ NMR spectra, with the characteristic ${ }^{1} J_{\mathrm{Rh}-\mathrm{C}}$ couplings for the case of the rhodium complexes $\left(\mathbf{1 C}^{\mathrm{Mes}}\right.$ : 173.4 ppm, ${ }^{1} J_{\text {Rh-C }}=41.5 \mathrm{~Hz} ; \mathbf{2 C}^{\text {Mes. }}: 172.1$ ppm, 3C ${ }^{\text {Mes: }}: 181.0$ ppm).

As an example, the ${ }^{1} \mathrm{H}$ and ${ }^{13} \mathrm{C}$ NMR spectra of $2 \mathrm{C}^{\text {Mes }}$ are described below. All the details regarding the characterization of $\mathbf{1} \mathbf{C}^{\text {Mes }}$ and $\mathbf{3} \mathbf{C}^{\text {Mes }}$ can be found in the Experimental Section (Chapter 5).

\section{${ }^{1} H$ NMR spectrum of $2 C^{M e s}$}

Figure 2.7 shows the ${ }^{1} \mathrm{H}$ NMR spectrum of $2 \mathrm{C}^{\mathrm{Mes}}$. The absence of the signal due to the protons of the NHCC groups, and the appearance of the signals corresponding to the COD ligand are indicative of the coordination of the tris-MIC ligand $\mathbf{C}^{\mathrm{Mes}}$ to the $\mathrm{Ir}^{(\mathrm{I})}$ fragment. The signals assigned to the protons of the 1,3,5-triphenylbenzene core (a, c and $\mathbf{b}$ ) are displayed at $8.05,7.78$ and $7.63 \mathrm{ppm}$. The signals due to the aromatic protons of the mesityl groups appear between 7.08-7.00 ppm, and those due to the methyl groups appear between 2.45 and $2.04 \mathrm{ppm}$. The signals corresponding to the protons of the carbon atoms of the COD ligands are displayed on the spectrum. 


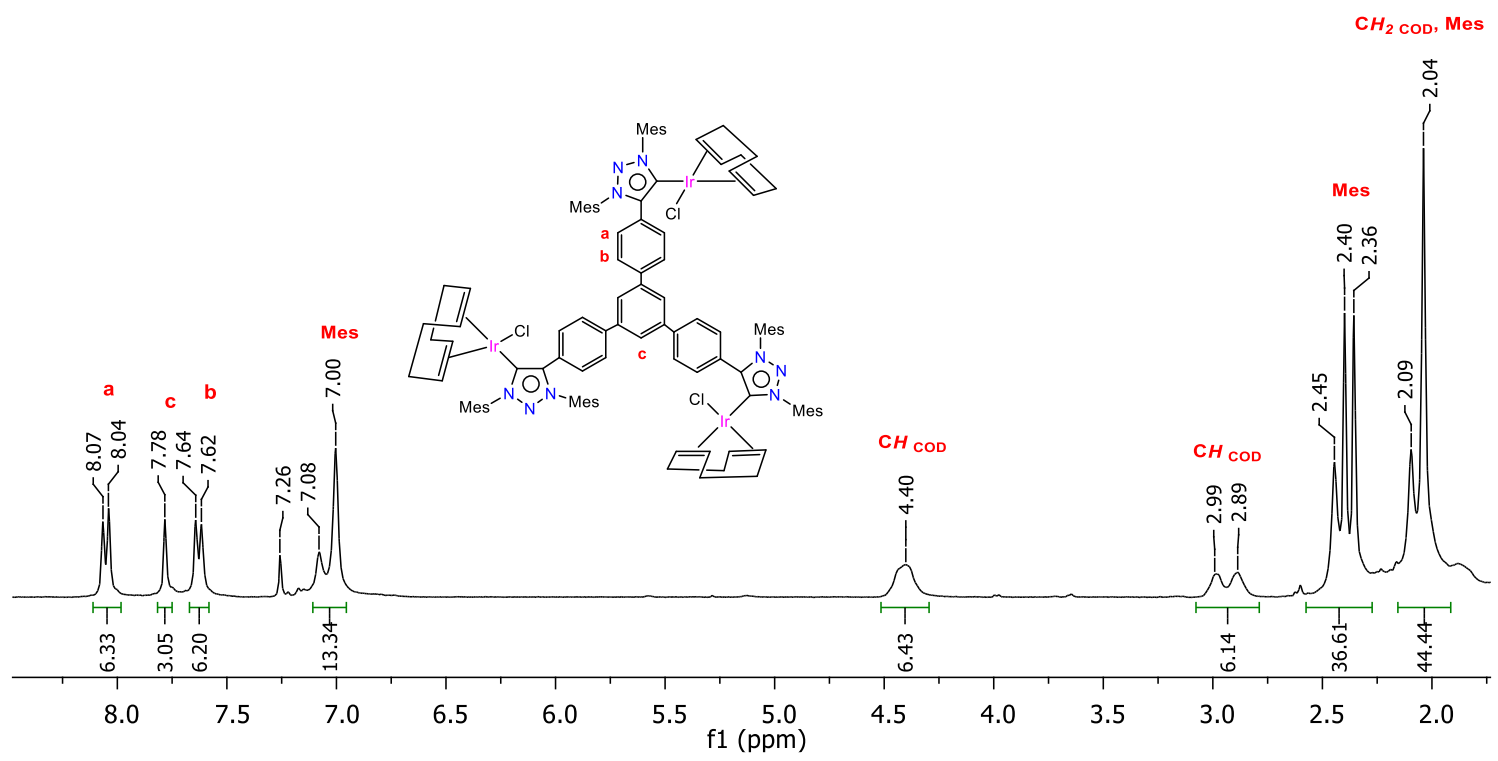

Figure 2.7. ${ }^{1} \mathrm{H}$ NMR spectrum of $2 \mathrm{C}^{\mathrm{Mes}}$ in $\mathrm{CDCl}_{3}$

\section{$\left.{ }^{13} C_{\{}{ }^{1} H\right\} N M R$ spectrum of $2 C^{\text {Mes }}$}

Figure 2.8 shows the ${ }^{13} \mathrm{C}\left\{{ }^{1} \mathrm{H}\right\}$ NMR spectrum of $2 \mathrm{C}^{\text {Mes }}$. The most characteristic signal is that attributed to the metallated carbene-carbon (1), which is displayed at $172.1 \mathrm{ppm}$. The signals attributed to the 1,3,5-triphenylbenzene core along with signals due to the aromatic carbons of the mesityl groups are displayed between 146.3-125.3 ppm. The signals due to the carbons of the three methyl groups of the mesityls appear between 21.4 and $17.7 \mathrm{ppm}$. The signals corresponding to the carbons of the COD ligand are conveniently displayed on the spectrum.

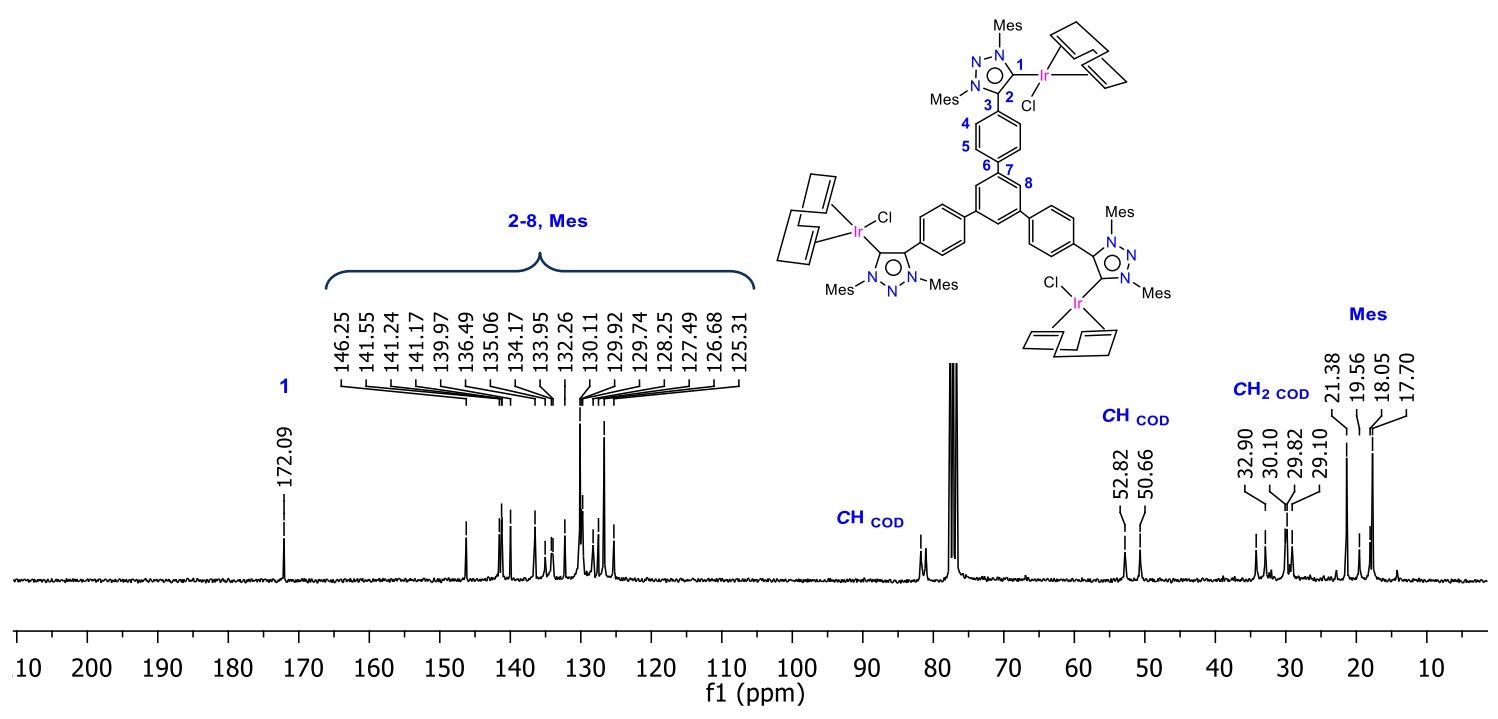

Figure 2.8. ${ }^{13} \mathrm{C}\left\{{ }^{1} \mathrm{H}\right\}$ NMR spectrum of $\mathbf{2} \mathrm{C}^{\mathrm{Mes}}$ in $\mathrm{CDCl}_{3}$ 


\subsubsection{NiCpCl complexes}

Prompted by the success in the synthesis of the $\mathrm{Rh}^{\mathrm{I}}$ and $\operatorname{Ir}^{\mathrm{I}}$ complexes, we decided to explore the coordination abilities of $\left[\mathbf{H}_{3} \mathbf{B}^{\mathrm{Et}}\right](\mathbf{X})_{3}\left(\mathrm{X}=\mathrm{BF}_{4}, \mathrm{PF}_{6}, \mathrm{Br}\right)$ and $\left[\mathbf{H}_{3} \mathbf{C}^{\mathrm{Mes}}\right]\left(\mathbf{P F}_{6}\right)_{3}$ with first row transition metals, such as iron and nickel. This work was done in collaboration with the group of Dr. Beatriz Royo from the Instituto de Tecnologia Química e Biológica da Universidade Nova de Lisboa, as a consequence of a research stay in her laboratory. As a result, a nickel complex based on the tris-MIC ligand was obtained. Unfortunately, all our attempts to obtain related Fe-based complexes failed. The synthetic procedure for the preparation of the tris-Ni complex $\mathbf{4} \mathbf{C}^{\mathrm{Mes}}$ is described in Scheme 2.6. The reaction of $\left[\mathbf{H}_{3} \mathbf{C}^{\mathbf{M e s}}\right]\left(\mathbf{P F}_{6}\right)_{3}$ with nickelocene $\left(\left[\mathrm{NiCp}_{2}\right]\right)$ in the presence of $\left[\mathrm{NEt}_{4}\right](\mathrm{Cl})$ in 1,4-dioxane under reflux, afforded the corresponding tris-MIC complex of $\mathrm{Ni}^{(\mathrm{II})} \mathbf{4 C ^ { \mathrm { Mes } }}$, as a red solid, in $40 \%$ yield after purification.

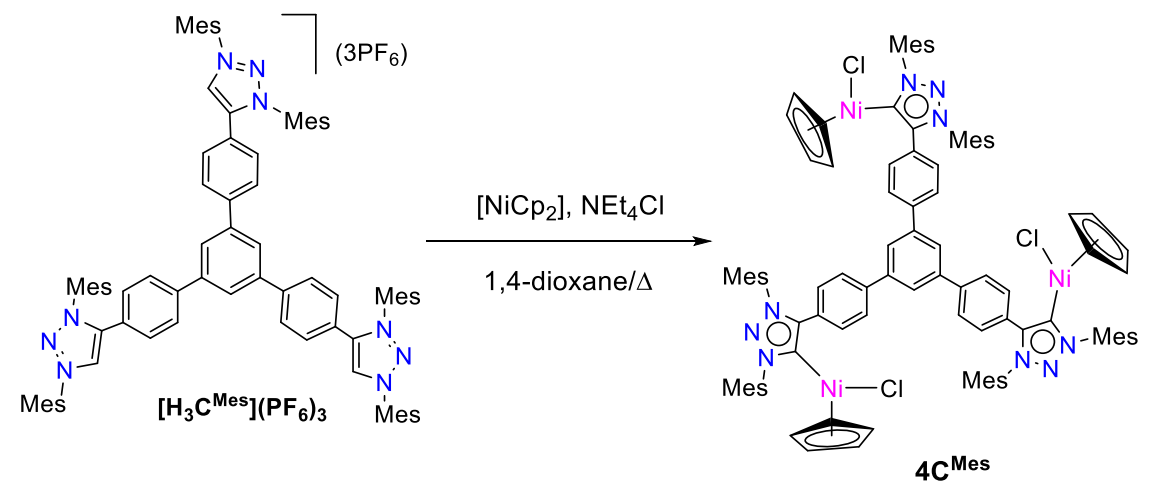

Scheme 2.6. Preparation of $4 C^{\text {Mes }}$

The threefold symmetry of complex $\mathbf{4} \mathbf{C}^{\text {Mes }}$ was confirmed by its ${ }^{1} \mathrm{H}$ NMR spectrum, which revealed a singlet due to the 15 protons at the three cyclopentadienyl ligands. The spectrum shows broad signals, probably as a consequence of the fluxionality due to the rotation about the $\mathrm{C}-\mathrm{C}$ sigma bonds of the tris-MIC ligand, and the $\mathrm{C}_{\text {carbene-Ni bond (see }}$ Figure 2.9). The ${ }^{13} \mathrm{C}\left\{{ }^{1} \mathrm{H}\right\}$ NMR spectrum of $\mathbf{4} \mathrm{C}^{\text {Mes }}$ displays the distinctive signal due to the equivalent metallated carbene carbons at $151.4 \mathrm{ppm}$, which falls close to the chemical shift shown by a previously reported $[\mathrm{NiCpCl}(\operatorname{trz})](\operatorname{trz}=$ triazolylidene $)$ complex (148 ppm). ${ }^{[16]}$ The trimetallic nature of the complex was confirmed by mass spectrometry, which revealed a peak at a $m / z$ value of 810.7 , assigned to $[\mathrm{M}-2 \mathrm{Cl}]^{2+}$. This compound is very interesting, because despite the fact that many [NiCpX(NHC)] 
complexes have already been reported, ${ }^{[17]}$ to our knowledge, this is the first $\mathrm{Ni}$ trimetallic complex featuring a tris-MIC ligand described so far.

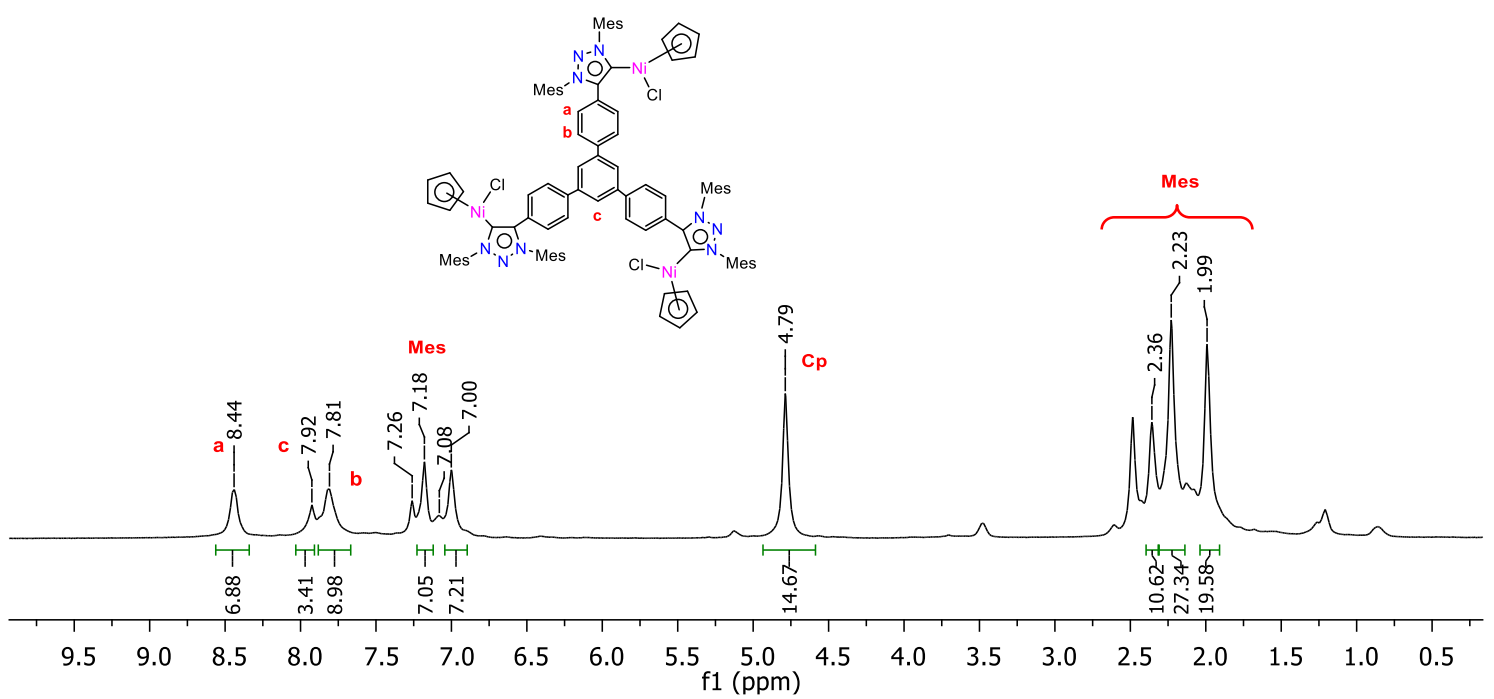

Figure 2.9. ${ }^{1} \mathrm{H} N M R$ spectrum of $4 C^{\text {Mes }}$ in $\mathrm{CDCl}_{3}$

\subsubsection{Electronic properties of tri- $v$ s. mono-metallic complexes}

In order to assess the electron-donating abilities of the ligands described in the previous sections, two different approaches were followed. The first one involved the preparation of the carbonyl derivatives of complexes $\mathbf{3} \mathbf{B}^{\mathrm{Et}}, \mathbf{4} \mathbf{B}^{\mathrm{Et}}$ and $\mathbf{3} \mathbf{C}^{\mathrm{Mes}}$, and the measurement of their corresponding $v(\mathrm{CO})$ stretching frequencies by means of IR spectroscopy. This provided us an indirect estimation of the TEP (Tolman Electronic Parameter). The second approach involves electrochemical measurements.

\subsubsection{Carbonyl derivatives}

Carbonyl complexes of the type $\left[\operatorname{IrCl}(\mathrm{L})(\mathrm{CO})_{2}\right](\mathrm{L}=\mathrm{NHC}$ or $\mathrm{MIC})$ have become broadly used for estimating TEP values, ${ }^{[18]}$ avoiding the disadvantages of the $\left[\mathrm{LNi}(\mathrm{CO})_{3}\right]$ system, which is highly toxic and difficult to obtain. The first correlations were established by the Crabtree's and then by the Nolan's groups. These research groups proposed a simple equation to determine the TEP values from the $v_{\mathrm{av}}(\mathrm{CO})$ frequencies of $\left[\operatorname{IrCl}(\mathrm{L})(\mathrm{CO})_{2}\right]$ complexes. ${ }^{[19]}$ Some years later, Wolf and Plenio extended their correlation to the use of $\left[\mathrm{RhCl}(\mathrm{L})(\mathrm{CO})_{2}\right]^{[20]}$ complexes.

In order to evaluate the electron-donating character of our tris-NHC and tris-MIC ligands, the corresponding rhodium and iridium hexacarbonyl complexes $\left(\mathbf{4} \mathbf{B}^{\mathrm{Et}}\right.$ and 3C $^{\text {Mes }}$ ) were obtained (Chart 2.5). These complexes were obtained by bubbling carbon 
monoxide into a solution of $\mathbf{2} \mathbf{B}^{\mathrm{Et}}$ and $\mathbf{2} \mathbf{C}^{\mathrm{Mes}}$ complexes in methylene chloride. (See Scheme 2.3 and Scheme 2.5)
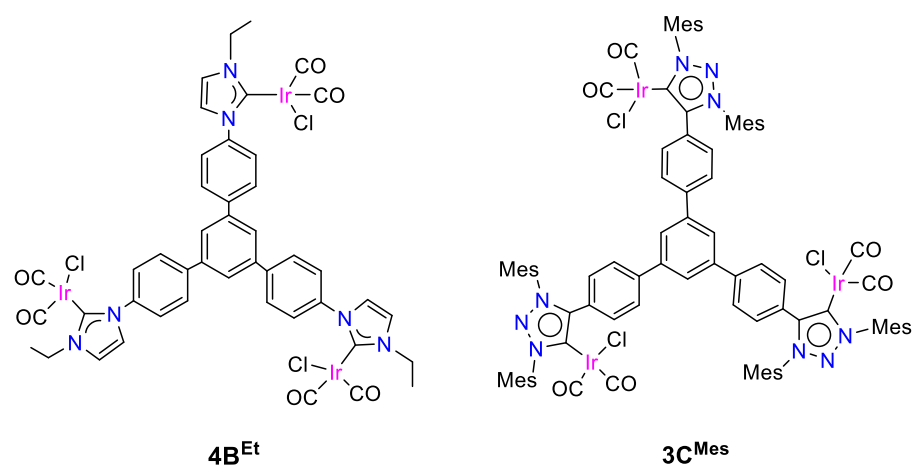

Chart 2.5. Schematic representation of complexes $\mathbf{4} \mathbf{B}^{\mathrm{Et}}$ and $\mathbf{3} \mathrm{C}^{\mathrm{Mes}}$

The average C-O stretching frequencies $\left[v(C O)_{\mathrm{av}}\left(\mathrm{cm}^{-1}\right)\right]$ of the tris- and mono-NHC and MIC complexes were determined by IR spectroscopy, and then the TEP values were estimated utilizing the well-known correlations. These data are shown in Table 2.3 .

Table 2.3. Carbonyl stretching frequencies and TEP values for complexes $\mathbf{4} B^{\mathrm{Et}}$ and $\mathbf{3} \mathbf{C}^{\mathrm{Mes}}$

\begin{tabular}{|c|c|c|c|}
\hline Entry & Complex & $v(\mathrm{CO})_{\mathrm{av}}\left(\mathrm{cm}^{-1}\right)^{\mathrm{a}}$ & $\operatorname{TEP}\left(\mathrm{cm}^{-1}\right)^{\mathrm{b}}$ \\
\hline 1 & $4 B^{E t}$ & 2018 & 2045 \\
\hline 2 & $3 C^{\text {Mes }}$ & 2014 & 2042 \\
\hline 3 & 00 & $2027^{[21]}$ & 2053 \\
\hline 4 & & $2019^{[11 c]}$ & 2046 \\
\hline
\end{tabular}

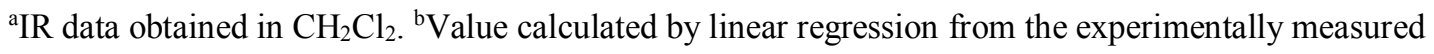
$v_{\mathrm{av}}(\mathrm{CO})$ of the $\left[\mathrm{LIrCl}(\mathrm{CO})_{2}\right]$ complex using TEP $=0.847 \mathrm{v}_{\mathrm{av}}(\mathrm{CO})+336\left(\mathrm{~cm}^{-1}\right)^{[19 \mathrm{~b}]}$

The higher TEP value observed for $\mathbf{4} \mathbf{B}^{\mathrm{Et}}$ compared to that shown by $\mathbf{3} \mathbf{C}^{\mathrm{Mes}}$ (entries 1 and 2) is indicative of the stronger electron-donating character of $\mathbf{C}^{\text {Mes }}$. This observation is in agreement with the TEP values obtained for the corresponding monometallic derivatives bearing the related NHC and MIC ligands (entries 3 and 4). ${ }^{[11 c, 21]}$ It should 
be taken into account that $\mathbf{B}^{\mathbf{E t}}$ and $\mathbf{C}^{\mathbf{M e s}}$, differ not only on their structural character (NHC vs. MIC), but also on their substituents at the nitrogen atom (alkyl vs. aryl), therefore this may also influence the electronic nature of the ligands.

In addition, the TEP value of $4 \mathbf{B}^{\mathbf{E}}$ differs on $-8 \mathrm{~cm}^{-1}$ compared to its monometallic derivative (compare entries 1 and 3), which indicates that the tris-NHC ligand presents a stronger electron-donating character than its mono-NHC analogue. In a similar way, the TEP of $3 C^{M e}$ differs on $-4 \mathrm{~cm}^{-1}$ with respect to its monometallic derivative (entries 2 and 4).

The results clearly indicate that the tritopic nature of $\mathbf{B}^{\mathbf{E t}}$ and $\mathbf{C}^{\mathbf{M e s}}$ is significantly improving the electron-donating ability of the ligands, thus suggesting that the triscarbene ligands should not simply be regarded as the combination of the three monocarbenes that constitute their structures.

\subsubsection{Electrochemical properties}

Cyclic Voltammetry (CV) studies were also employed to evaluate the electronic properties of the carbene ligands. The first reports using this technique were those by Plenio, Crabtree, Peris and co-workers, ${ }^{[17 a, d, 22]}$ who performed their studies by using a selected series of rhodium, iridium and nickel complexes. This technique is also a valuable tool for determining the metal-to-metal electronic communication in multimetallic systems. ${ }^{[23]}$

We performed cyclic voltammetric studies of complexes $\mathbf{1 B}^{\mathbf{E t}}$ and $\mathbf{2} \mathbf{B}^{\mathrm{Et}}$ (Chart 2.6). Both species showed irreversible redox event, probably due to the low steric shielding about the metal, which makes the oxidised species to be highly unstable, as previously described in the literature for similar systems. ${ }^{[24]}$ For comparative purposes, the results provided by these two trimetallic complexes were compared to their monometallic analogues, $\mathbf{1 D}^{\mathrm{Et}}$ and $\mathbf{2} \mathbf{D}^{\mathrm{Et}}$, which were specifically synthesized for this purpose.

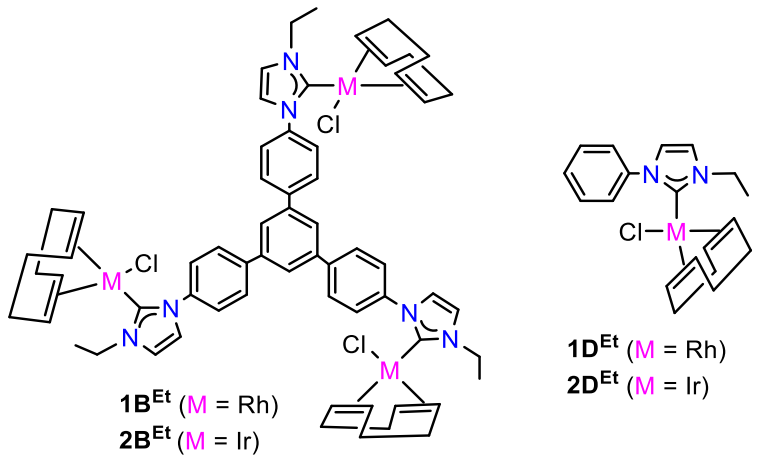

Chart 2.6. $\mathrm{Rh}^{\mathrm{I}}$ and $\operatorname{Ir}^{\mathrm{I}}$ metal complexes containing tris-NHC and mono-NHC ligands 
The cyclic voltammetric diagrams obtained for the two iridium complexes $\mathbf{2 B}^{\mathbf{E t}}$ and $\mathbf{2 D}^{\mathrm{Et}}$ (Figure 2.10), display oxidation waves at a similar wave potential $\left(\mathrm{E}_{\text {oxid }}=0.71 \mathrm{~V}\right)$. This result indicates that both ligands (the tris-NHC ligand in $\mathbf{2} \mathbf{B}^{\mathbf{E t}}$ and the mono-NHC in $\mathbf{2 D}^{\mathrm{Et}}$ ) provide a similar electron-donating ability. ${ }^{[20,22 \mathrm{a}]}$ By comparing the curves obtained from the Differencial Pulse Voltammetry (DPV) it can be observed that there is not any detectable broadening of the signal provided by the trimetallic complex, compared to that generated by the monometallic one. This result indicates that the trimetallic complex $\mathbf{2} \mathbf{B}^{\mathrm{Et}}$ contains three essentially decoupled iridium fragments. A bi- or tri-metallic system with effective metal-to-metal communication should be expected to show two or three independent waves, each one assigned to the oxidation of each metal center. Alternatively, a significant broadening of the redox wave should be expected for a weakly electronically coupled system.
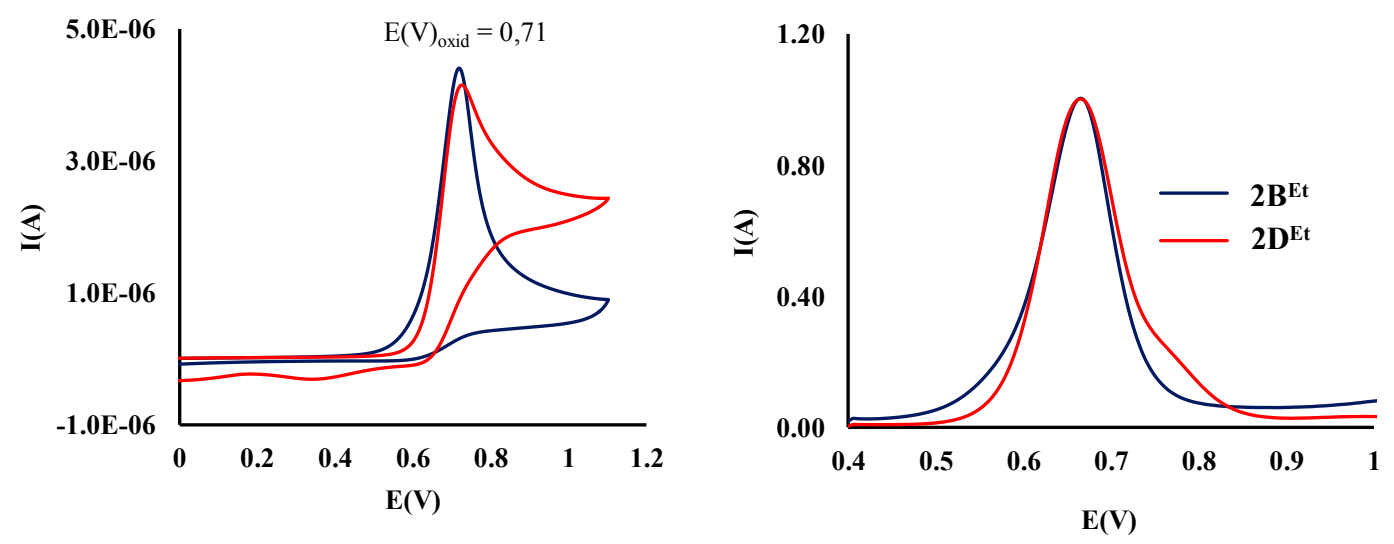

Figure 2.10. CV plot (left) and relevant DPV section (right) of complexes $\mathbf{2 B}^{\mathbf{E t}}$ and $\mathbf{2} \mathbf{D}^{\mathbf{E t}}$ (1mM in dry $\mathrm{CH}_{2} \mathrm{Cl}_{2}$ with $0.1 \mathrm{M}\left[\mathrm{NBu}_{4}\right]\left[\mathrm{PF}_{6}\right]$ as the supporting electrolyte, $50 \mathrm{mVs}^{-1}$ scan rate, $\mathrm{Fc}^{+} / \mathrm{Fc}$ used as internal standard with $\left.\mathrm{E}_{1 / 2}\left(\mathrm{Fc} / \mathrm{Fc}^{+}\right)=0.44 \mathrm{~V} v s . \mathrm{SCE}\right)$

The cyclic voltammetry studies of $\mathbf{1} \mathbf{C}^{\text {Mes }}, \mathbf{2 C}^{\text {Mes }}$ and $\mathbf{4} \mathbf{C}^{\text {Mes }}$ were also performed to gain further insight into the electronic properties of the tris-MIC ligands. 


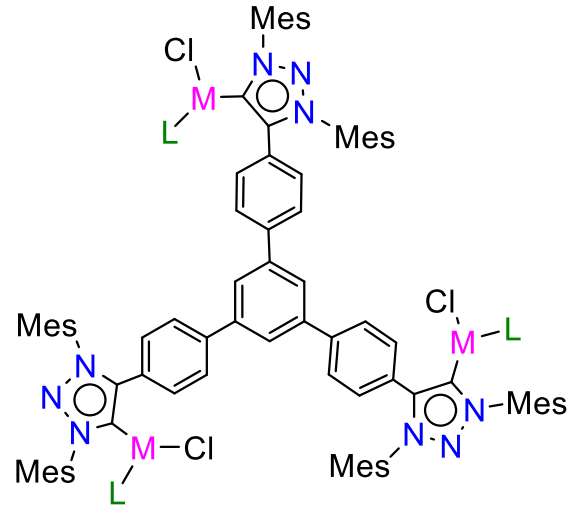

$$
\begin{aligned}
& 1 C^{\text {Mes }}(M=R h, L=C O D) \\
& 2 C^{\text {Mes }}(M=I r, L=C O D) \\
& 4 C^{\text {Mes }}(M=N i, L=C p)
\end{aligned}
$$

Chart 2.7. Tris-MIC complexes under study

The rhodium complex $\mathbf{1 C}^{\text {Mes }}$ showed an irreversible redox event at $\mathrm{E}_{\text {oxid }}=0.65 \mathrm{~V}$ (Figure 2.10, solid line), while the iridium complex 2C $\mathbf{C}^{\text {Mes }}$ (Figure 2.10, dotted line), showed a pseudo-reversible redox event at $\mathrm{E}_{\text {oxid }}=0.69 \mathrm{~V}$. Compared to the cyclic voltammetry data for the analogue complexes of rhodium and iridium with the tris-NHC ligand $\mathbf{B}^{\mathbf{E t}}\left(\mathrm{E}_{\text {oxid }}=0.71 \mathrm{~V}\right.$, for both complexes $),{ }^{[10 \mathrm{a}]}$ the lower $\mathrm{E}_{\text {oxid }}$ value for $\mathbf{1} \mathbf{C}^{\mathrm{Mes}}$ and $\mathbf{2 C}^{\mathrm{Mes}}$ is consistent with a higher electron-donating character of the tris-MIC ligand $\mathbf{C}^{\text {Mes }}$. Again, the appearance of only one redox wave for both complexes, $\mathbf{1 C}^{\text {Mes }}$ and $2 \mathrm{C}^{\mathrm{Mes}}$, is consistent with the lack of electronic communication between the three metal centers for both trimetallic complexes.

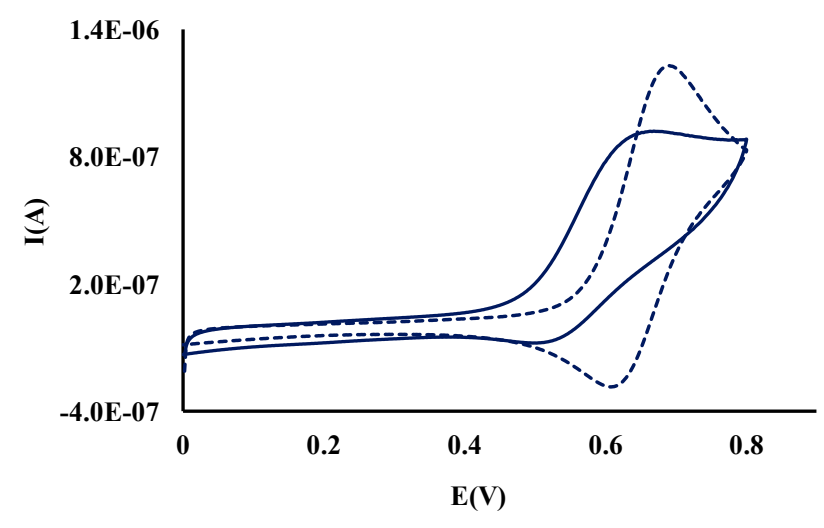

Figure 2.10. $\mathrm{CV}$ plots of complexes $\mathbf{1 C}^{\mathrm{Mes}}$ (solid line), and $\mathbf{2 C}^{\mathrm{Mes}}$ (dotted line). Experiments carried out using $1 \mathrm{mM}$ solutions of the complexes in dry $\mathrm{CH}_{2} \mathrm{Cl}_{2}$ with $0.1 \mathrm{M}\left[\mathrm{NBu}_{4}\right]\left[\mathrm{PF}_{6}\right]$ as the supporting electrolyte, $100 \mathrm{mVs}^{-1}$ scan rate, $\mathrm{Fc}^{+} / \mathrm{Fc}$ used as internal standard with $\mathrm{E}_{1 / 2}\left(\mathrm{Fc} / \mathrm{Fc}^{+}\right)=0.44 \mathrm{~V} v s$. SCE

$[\mathrm{NiClCp}(\mathrm{NHC})]$ often show reversible and well-behaved electrochemical responses, ${ }^{[17 \mathrm{a},}$ d] and are known to serve as excellent proves for the evaluation of the electron-donating character of their NHC ligands. In addition, to our knowledge there are not examples of 
cyclic voltammetry studies on $[\mathrm{NiClCp}(\mathrm{MIC})]$ complexes. The cyclic voltammetry diagram of the tris- $\mathrm{Ni}^{(\mathrm{II})}$ complex $\mathbf{4} \mathrm{C}^{\text {Mes }}$ is shown in Figure 2.11, together with the relevant section of the DPV plot. The complex showed a quasi-reversible wave at a half-wave potential of $E_{1 / 2}=0.64 \mathrm{~V}$, which is significantly lower than the half-wave potential shown by complex [NiCpCl(IMes)] (IMes = 1,3-mesityl-imidazolylidene), ${ }^{[17 \mathrm{a}]}$ which showed a half-wave potential of $E_{1 / 2}=0.72 \mathrm{~V}$. As expected, this result is consistent with the higher degree of electron-donating character for the ligand in $\mathbf{4} \mathbf{C}^{\mathrm{Mes}}$ compared to IMes. It can be established that there is only one redox event taking place, and thus it becomes evident that the tri-metallic complex $\mathbf{4} \mathbf{C}^{\mathrm{Mes}}$ contains three essentially decoupled nickel fragments.
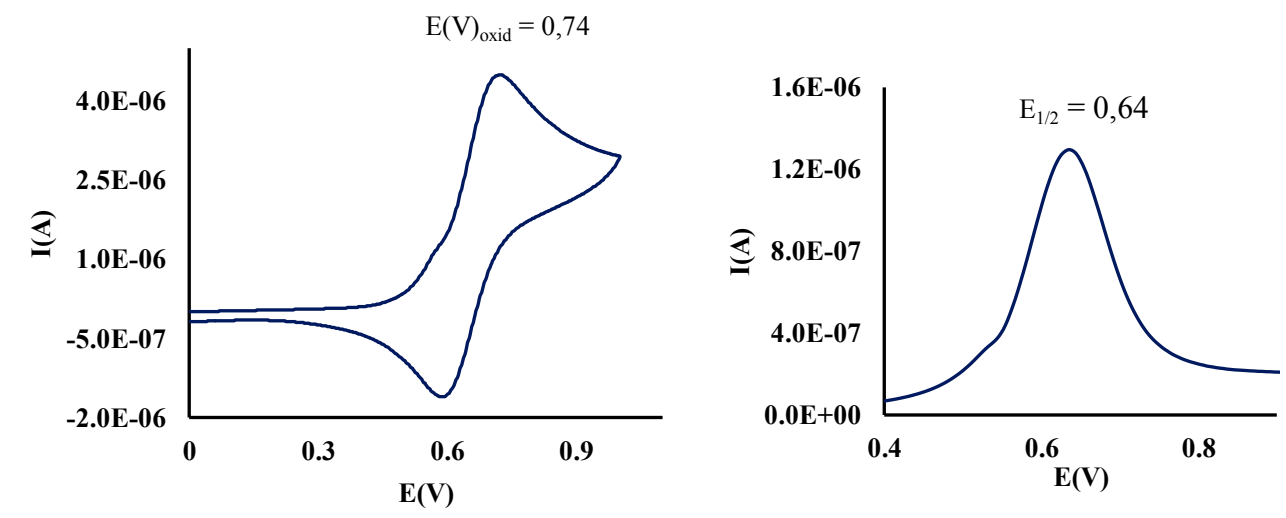

Figure 2.11. $\mathrm{CV}$ plot (left) and relevant DPV section (right) of complex $4 \mathrm{C}^{\mathrm{Mes}}\left(1 \mathrm{mM}\right.$ in $\operatorname{dry~} \mathrm{CH}_{2} \mathrm{Cl}_{2}$ with $0.1 \mathrm{M}\left[\mathrm{NBu}_{4}\right]\left[\mathrm{PF}_{6}\right]$ as the supporting electrolyte, $50 \mathrm{mVs}^{-1}$ scan rate, $\mathrm{Fc}^{+} / \mathrm{Fc}$ used as internal standard with $\left.\mathrm{E}_{1 / 2}\left(\mathrm{Fc} / \mathrm{Fc}^{+}\right)=0.44 \mathrm{~V} v s . \mathrm{SCE}\right)$.

\subsubsection{Catalytic studies}

\subsubsection{Catalytic activity of the trimetallic rhodium complexes: 1,4- Addition of Arylboronic Acids to Cyclohex-2-one}

The 1,4-addition of nucleophiles to $\alpha, \beta$-unsaturated compounds represents one of the main organic transformation for the production of key intermediates in the pharmaceutical industry. ${ }^{[25]}$ This process is a convenient synthetic pathway for the formation of $\mathrm{C}-\mathrm{C}$ bonds. ${ }^{[26]}$ Although copper is the most widely used metal for this type of reactions, ${ }^{[27]}$ it shows, together with Grignard reagents, some important disadvantages, such as low temperature thresholds and high water sensitivity. 
Rhodium catalysts have recently shown to provide some benefits into this reaction, especially since they allow the use of mild organometallic reagents and often afford high chemoselectivities. Rhodium catalysts also allow the use of aryl nucleophiles, which cannot be coupled when $\mathrm{Cu}$-based catalysts are used. ${ }^{[28]}$

In this context, Nolan and co-workers reported an efficient rhodium catalyst that combines the presence of a strongly electron-donating $\mathrm{N}$-heterocyclic carbene and a poorly electron-donating bidentate cyclooctadiene ligand. ${ }^{[29]}$

Prompted by these results, we decided to evaluate the catalytic activity of our rhodium complexes in the addition of arylboronic acids to an $\alpha, \beta$-unsaturated ketone, such as cyclohex-2-one (Scheme 2.7). ${ }^{[29-30]}$

First, we studied the catalytic activity of the tris-NHC-rhodium complex $\left(\mathbf{1 B}^{\mathrm{Et}}\right)$, which was compared with its monometallic analogue (1D $\left.{ }^{\mathbf{E t}}\right)$ (Chart 2.8). Then, for comparison, we decided to study the activity of the complex tris-MIC rhodium complex $\mathbf{1 C}^{\text {Mes }}$ for the same reaction.
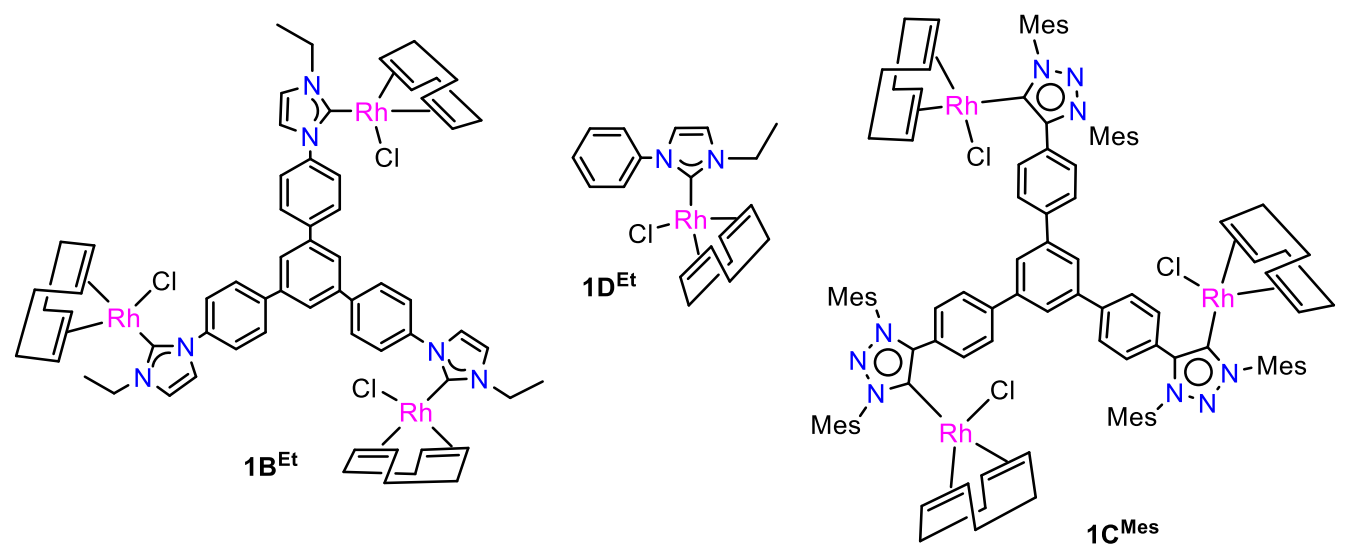

Chart 2.8. Schematic representation of complexes $1 B^{\mathrm{Et}}, \mathbf{1 C}^{\mathrm{Mes}}$ and $1 \mathrm{D}^{\mathrm{Et}}$

The fact that the three metal centers in $\mathbf{1} \mathbf{B}^{\mathrm{Et}}$ and $\mathbf{1} \mathbf{C}^{\mathrm{Mes}}$ are essentially electronically disconnected, suggests that the ligand may be used to support different metal fragments without detriment of their potential catalytic properties, and thus should constitute a good opportunity to study cooperative effects. Also, the fact that the mono-NHC ligand in $\mathbf{1 D}^{\mathrm{Et}}$ provides with almost identical stereoelectronic properties as those offered by the tri-NHC ligand in $\mathbf{1 B}^{\mathbf{E t}}$, gives us an excellent opportunity to compare the catalytic activities provided by the trimetallic complexes and their monometallic analogues.

Table 2.4 shows some selected results on the addition of arylboronic acids to cyclohex2-one. As can be observed from the data shown, higher conversions were obtained when 
the reactions were carried out in toluene, than in a mixture of $\mathrm{THF} / \mathrm{H}_{2} \mathrm{O}$. This result is rather surprising, if we take into account that this reaction is generally performed in the presence of water, ${ }^{[30 \mathrm{~d}]}$ and the examples in which dry toluene is used have been regarded as rare, and only promoted when $\mathrm{OH}$ groups are forming part of the ancillary ligands, which is not our case.

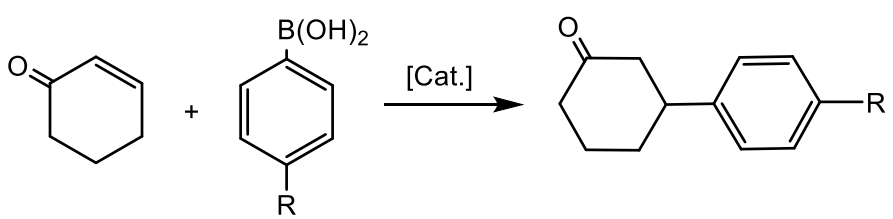

Scheme 2.7. 1,4-Addition of aryl boronic acids to cyclohex-2-one

Table 2.4. 1,4-Addition of arylboronic acids to cyclohex-2-one ${ }^{\mathrm{a}}$ using $\mathbf{1 B} \mathbf{B}^{\mathrm{Et}}$ (trimetallic) and $\mathbf{1 D}^{\mathbf{E t}}$ (monometallic) as catalysts

\begin{tabular}{|c|c|c|c|c|c|}
\hline Entry & [Cat.] (mol \%) & Solvent & $\mathrm{R}$ & [Cat.] & Conv. $(\%)^{b}$ \\
\hline 1 & 0.066 & $\mathrm{THF} / \mathrm{H}_{2} \mathrm{O}$ & $\mathrm{H}$ & $1 B^{E t}$ & $56(45)$ \\
\hline 2 & 0.2 & $\mathrm{THF} / \mathrm{H}_{2} \mathrm{O}$ & $\mathrm{H}$ & $1 D^{\mathrm{Et}}$ & $58(46)$ \\
\hline 3 & 0.066 & $\mathrm{THF} / \mathrm{H}_{2} \mathrm{O}$ & $\mathrm{Me}$ & $1 B^{E t}$ & $63(53)$ \\
\hline 4 & 0.2 & $\mathrm{THF} / \mathrm{H}_{2} \mathrm{O}$ & $\mathrm{Me}$ & $1 D^{\mathrm{Et}}$ & $74(50)$ \\
\hline 5 & 0.066 & Toluene & $\mathrm{H}$ & $1 B^{E t}$ & $100(91)$ \\
\hline 6 & $6.610^{-3}$ & Toluene & $\mathrm{H}$ & $1 B^{E t}$ & $71(68)$ \\
\hline 7 & 0.2 & Toluene & $\mathrm{H}$ & $1 D^{\mathrm{Et}}$ & $96(90)$ \\
\hline 8 & 0.02 & Toluene & $\mathrm{H}$ & $1 D^{\mathrm{Et}}$ & $61(48)$ \\
\hline 9 & 0.066 & Toluene & $\mathrm{Me}$ & $1 B^{E t}$ & $85(69)$ \\
\hline 10 & 0.2 & Toluene & $\mathrm{Me}$ & $1 D^{\mathrm{Et}}$ & $69(55)$ \\
\hline $11^{\mathrm{c}}$ & 0.066 & Toluene & $\mathrm{OMe}$ & $1 B^{E t}$ & $48(16)$ \\
\hline $12^{\mathrm{c}}$ & 0.2 & Toluene & $\mathrm{OMe}$ & $1 D^{\mathrm{Et}}$ & $47(14)$ \\
\hline
\end{tabular}

${ }^{a}$ Conditions: Cyclohexen-2-one $(0.5 \mathrm{mmol}), \mathrm{KOH}(0.09 \mathrm{mmol}), \mathrm{ArB}(\mathrm{OH})_{2}(0.6 \mathrm{mmol})$, dry solvent for entries 5-12. ${ }^{\mathrm{b} C o n v e r s i o n s ~ d e t e r m i n e d ~ b y ~ g a s ~ c h r o m a t o g r a p h y ~(G C), ~ u s i n g ~ a n i s o l e ~ a s ~ i n t e r n a l ~ s t a n d a r d . ~}$

Yields given in parenthesis. ${ }^{c}$ Using 2,4,6-trimethylphenol as standard

It is worth mentioning that we did not need additives to the reaction mixtures, in order to improve the catalytic outcomes. Regardless of the type of solvent used, the two 
catalysts afforded very similar reaction outcomes, therefore suggesting that the higher nanolocal concentration provided by the trimetallic complex (dendrimer effect) ${ }^{\left[{ }^{31]}\right.}$ did not have any significant effect in its activity. This means that the trimetallic nature of $\mathbf{1 B}^{\mathbf{E t}}$ does not provide any improvement compared to its monometallic analogue. The representation of the reaction profiles for the reaction between phenylboronic acid and cyclohex-2-one (Figure 2.12), gives a good illustration of the quasi-identical behavior of the two catalysts.

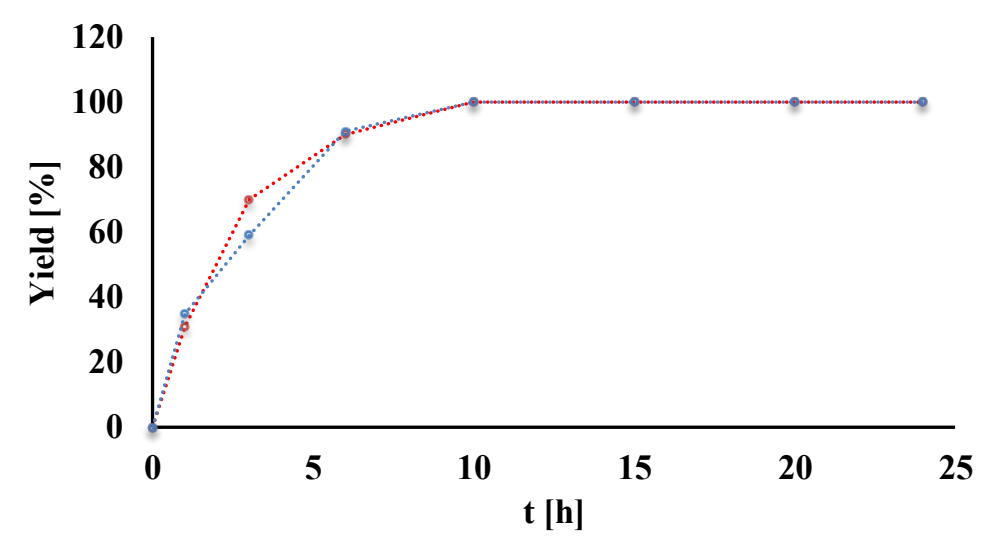

Figure 2.12. Time course for the addition of phenyl boronic acid to cyclohex-2-one. Reactions carried out in toluene at $100^{\circ} \mathrm{C}$, with a $0.06\left(\mathbf{1 B}^{\mathrm{Et}}\right.$ : blue) or $0.2\left(\mathbf{1 D}^{\mathrm{Et}}\right.$ : red) $\mathrm{mol} \%$ of catalyst loading. Yields were determined by GC, using anisole as internal standard

This observation is interesting, and may be related to previous observations made by our research group, in which the use of $\pi$-extended polyaromatic-based di- and tri-NHC ligands produced significant improvements of the catalytic activities of their related complexes, compared to their monometallic analogues. ${ }^{[4,32]}$ In those cases, the catalytic benefits were attributed to the $\pi$-stacking between the substrates and the core of the $\pi$ extended polyaromatic ligand, a situation that may not be reproduced in this new case, in which the NHC moieties are $\pi$-disconnected from the polyaromatic core. It is also worth mentioning that for the reactions carried out at catalyst loadings of $6.6 \times 10^{-3}$ and $0.02 \mathrm{~mol} \%$ for $\mathbf{1 B}^{\mathrm{Et}}$ and $\mathbf{1} \mathbf{D}^{\mathrm{Et}}$, respectively (entries 11 and 12), the yields obtained after $6 \mathrm{~h}$ are moderately high, therefore illustrating the high activity of the catalysts even at very low catalyst loadings.

We observed that a side-reaction involving the deborylation of the aryl boronic acid is also taking place in this reaction. This would explain the differences found between conversions and yields for most of the reactions that we studied. This observation is 
more relevant in the case of phenylboronic acid, for which the formation of anisole from 4-methoxy-phenylboronic acid is the dominant process (entries 11 and 12).

In order to compare the activity of the tri-NHC complex $\mathbf{1 B}^{\mathrm{Et}}$ with the tri-MIC complex $\mathbf{1} \mathbf{C}^{\text {Mes }}$, catalyst $\mathbf{1 C}^{\text {Mes }}$ was also tested in the 1,4-addition of arylboronic acids to cyclohex-2-one, using the same reaction conditions. Table 2.5 shows the results obtained, together with the results given by the use of the tris-NHC catalyst $\mathbf{1 B}^{\mathbf{E t}}$ to facilitate a direct comparison.
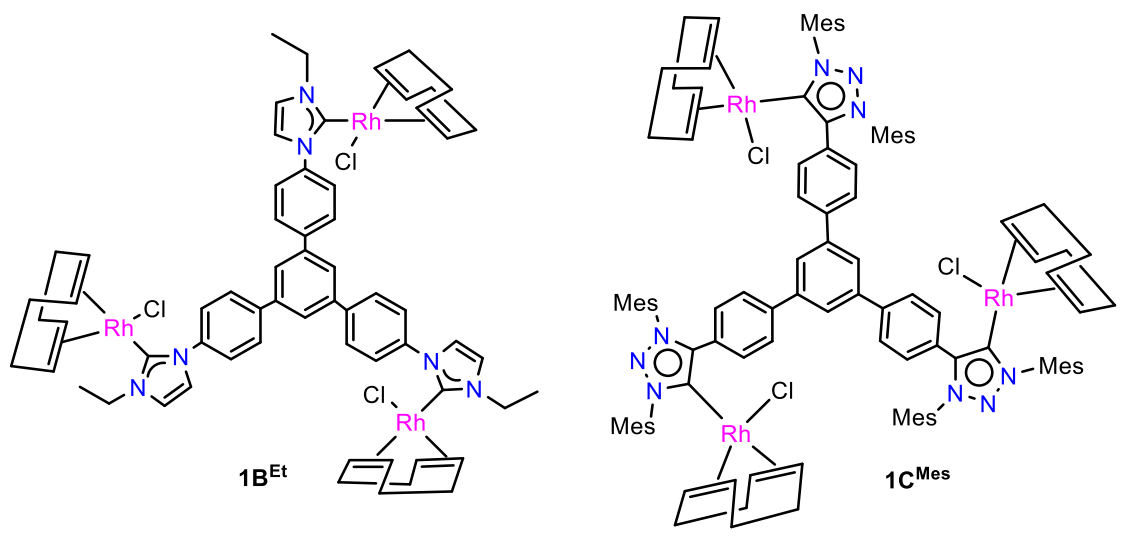

Chart 2.9. Schematic representation of catalysts $1 B^{\text {Et }}$ and $1 C^{\text {Mes }}$

Table 2.5. 1,4-Addition of arylboronic acids to cyclohex-2-one $\mathrm{u}^{\mathrm{a}}$ using $\mathbf{1 B}^{\mathrm{Et}}$ and $\mathbf{1 C}^{\mathrm{Mes}}$ as catalysts

\begin{tabular}{cccc}
\hline Entry & $\mathrm{R}$ & {$[$ Cat. $]$} & Conv.(\%) \\
\hline 1 & $\mathrm{H}$ & $\mathbf{1 B}^{\mathbf{E t}}$ & $100(91)^{\mathrm{a}}$ \\
2 & $\mathrm{H}$ & $\mathbf{1 C}^{\text {Mes }}$ & $66(43)^{\mathrm{b}}$ \\
3 & $\mathrm{Me}$ & $\mathbf{1 B}^{\mathbf{E t}}$ & $85(69)^{\mathrm{a}}$ \\
4 & $\mathrm{Me}$ & $\mathbf{1 C}^{\text {Mes }}$ & $63(34)^{\mathrm{b}}$ \\
5 & OMe & $\mathbf{1 B}^{\mathbf{E t}}$ & $48(16)^{\mathrm{b}}$ \\
6 & OMe & $\mathbf{1 C}^{\text {Mes }}$ & $52(15)^{\mathrm{b}}$ \\
\hline
\end{tabular}

Reaction conditions: Catalyst (0.066 mol \%), 2-cyclohexen-1-one (0.5 mmol), KOH (0.09 mmol), $\mathrm{ArB}(\mathrm{OH})_{2}(0.6 \mathrm{mmol})$, dry toluene $(3 \mathrm{~mL})$. Conversions determined by gas chromatography $(\mathrm{GC})$, using ${ }^{\mathrm{a}}$ anisole or ${ }^{\mathrm{b}}$ 2,4,6-trimethylphenol as internal standards. Yields are given in parenthesis. The results given for the use of complex $\mathbf{1} \mathbf{B}^{\mathbf{E t}}$ were taken from ref ${ }^{[10 \mathrm{a}]}$.

From the results shown, it can be observed that the activity of complex $\mathbf{1 C}^{\text {Mes }}$ is lower than the activity shown by $\mathbf{1 B}^{\mathrm{Et}}$, both in terms of conversion and selectivity. For all the 
reactions where $\mathbf{1 C}^{\text {Mes }}$ was used, a side-reaction involving the deborylation of the aryl boronic acid was observed. This justifies the large differences found between conversions and yields for all of the reactions that we have studied. This observation is more pronounced in the case of 4-methoxy-phenylboronic acid, for which the formation of anisole is the dominant process (entries 5 and 6).

\subsection{Conclusions}

In this Chapter we described the synthesis and characterization of several trisimidazolium and tris-triazolium salt precursors based on a triphenylbenzene core. The photophysical properties of the tris-imidazolium salts were evaluated, indicating that some of salts precursors exhibit fluorescence emission in the 320-420 nm region and moderate quantum yields.

These salts were used as tris-carbene ligand precursors, which were coordinated to $\mathrm{Rh}^{(\mathrm{I})}$, $\mathrm{Ir}^{(\mathrm{I})}$ and $\mathrm{Ni}^{(\mathrm{II})}$. The complexes were fully characterized by standard spectroscopic and microanalytical techniques. Some of the monometallic analogues were also synthesized and characterized for comparative purposes.

The electron-donating character of the triscarbene ligands was established by means of IR spectroscopy and electrochemical measurements. The electronic communication between metals was found to be almost negligible.

The catalytic activity of the tri- and monometallic rhodium complexes was evaluated toward the addition of arylboronic acids to an $\alpha, \beta$-unsaturated ketone, showing that the catalytic activity of the trimetallic complex is comparable to itse monometallic counterpart. In addition, it was concluded that for this particular reaction, the performance of the metal complex containing the strong electron-donating tris-MIC ligand does not afford an improvement on the catalytic activity compared to the related tris-NHC-based complex for this specific reaction.

In summary, this Chapter illustrates the high coordination versatility of the new trisNHC and tris-MIC ligands, their photochemical, electronic and catalytic properties. 


\subsection{References}

[1] a) J. A. Mata, M. Poyatos and E. Peris, Coord. Chem. Rev. 2007, 251, 841-859; b) M. Poyatos, J. A. Mata and E. Peris, Chem. Rev. 2009, 109, 3677-3707.

[2] a) K. A. Williams, A. J. Boydston and C. W. Bielawski, Chem. Soc. Rev. 2007, 36, 729-744; b) B. C. Norris and C. W. Bielawski, Macromolecules 2010, 43, 3591-3593; c) A. B. Powell, C. W. Bielawski and A. H. Cowley, Comments Inorg. Chem. 2010, 31, 75-82; d) O. Schuster, L. Mercs and M. Albrecht, Chimia 2010, 64, 184-187; e) B. M. Neilson, A. G. Tennyson and C. W. Bielawski, J. Phys. Org. Chem. 2012, 25, 531-543.

[3] J. A. Mata, F. E. Hahn and E. Peris, Chem. Sci. 2014, 5, 1723.

[4] S. Gonell, M. Poyatos and E. Peris, Angew. Chem. Int. Ed. 2013, 52, 7009-7013.

[5] S. Gonell, M. Poyatos and E. Peris, Chem. Eur. J. 2014, 20, 5746-5751.

[6] A. Rit, T. Pape and F. E. Hahn, J. Am. Chem. Soc. 2010, 132, 4572-4573.

[7] K. A. Williams and C. W. Bielawski, Chem. Commun. 2010, 46, 5166-5168.

[8] S. Gonell, R. G. Alabau, M. Poyatos and E. Peris, Chem. Commun. 2013, 49, 7126-7128.

[9] E. Peris, Chem. Commun. 2016, 52, 5777-5787.

[10] a) C. Mejuto, G. Guisado-Barrios and E. Peris, Organometallics 2014, 33, 32053211; b) N. Sinha, F. Roelfes, A. Hepp, C. Mejuto, E. Peris and F. E. Hahn, Organometallics 2014, 33, 6898-6904; c) C. Mejuto, G. Guisado-Barrios, D. Gusev and E. Peris, Chem. Commun. 2015, 51, 13914-13917; d) C. Mejuto, B. Royo, G. Guisado-Barrios and E. Peris, Beilstein J. Org. Chem. 2015, 11, 25842590 .

[11] a) P. Mathew, A. Neels and M. Albrecht, J. Am. Chem. Soc. 2008, 130, 1353413535; b) G. Guisado-Barrios, J. Bouffard, B. Donnadieu and G. Bertrand, Angew. Chem. Int. Ed. 2010, 49, 4759-4762; c) J. Bouffard, B. K. Keitz, R. Tonner, G. Guisado-Barrios, G. Frenking, R. H. Grubbs and G. Bertrand, Organometallics 2011, 30, 2617-2627.

[12] a) I. A. Khotina, V. A. Izumrudov, N. V. Tchebotareva and A. L. Rusanov, Macromol. Chem. Phys. 2001, 202, 2360-2366; b) N. I. Nijegorodov and W. S. Downey, Spectrochimi. Acta A 1995, 51, 2335-2346.

[13] a) N. I. Nizhegorodov, V. P. Zvolinskii and E. N. Smirnova, Zh. Fiz. Khim. 1992, 66, 3060-3065; b) I. B. Berlman, J. Chem. Phys. 1970, 52, 5616. 
[14] a) C. Segarra, G. Guisado-Barrios, F. E. Hahn and E. Peris, Organometallics 2014, 33, 5077-5080; b) A. Rit, T. Pape, A. Hepp and F. E. Hahn, Organometallics 2011, 30, 334-347.

[15] S. H. Lim and S. M. Cohen, Inorg. Chem. 2013, 52, 7862-7872.

[16] Y. Wei, A. Petronilho, H. Mueller-Bunz and M. Albrecht, Organometallics 2014, $33,5834-5844$.

[17] a) O. R. Luca, B. A. Thompson, M. K. Takase and R. H. Crabtree, J. Organomet. Chem. 2013, 730, 79-83; b) C. D. Abernethy, A. H. Cowley and R. A. Jones, J. Organomet. Chem. 2000, 596, 3-5; c) R. A. Kelly, N. M. Scott, S. Diez-Gonzalez, E. D. Stevens and S. P. Nolan, Organometallics 2005, 24, 3442-3447; d) H. Valdes, M. Poyatos, G. Ujaque and E. Peris, Chem. Eur. J. 2015, 21, 1578-1588.

[18] C. A. Tolman, Chem. Rev. 1977, 77, 313-348.

[19] a) A. R. Chianese, X. W. Li, M. C. Janzen, J. W. Faller and R. H. Crabtree, Organometallics 2003, 22, 1663-1667; b) R. A. Kelly, III, H. Clavier, S. Giudice, N. M. Scott, E. D. Stevens, J. Bordner, I. Samardjiev, C. D. Hoff, L. Cavallo and S. P. Nolan, Organometallics 2008, 27, 202-210.

[20] S. Wolf and H. Plenio, J. Organomet. Chem. 2009, 694, 1487-1492.

[21] D. G. Gusev, Organometallics 2009, 28, 6458-6461.

[22] a) S. Leuthausser, D. Schwarz and H. Plenio, Chem. Eur. J. 2007, 13, 7195-7203; b) S. Wolf and H. Plenio, J. Organomet. Chem. 2010, 695, 2418-2422; c) H. Valdes, M. Poyatos and E. Peris, Organometallics 2014, 33, 394-401.

[23] a) A. G. Tennyson, E. L. Rosen, M. S. Collins, V. M. Lynch and C. W. Bielawski, Inorg. Chem. 2009, 48, 6924-6933; b) L. Mercs, A. Neels and M. Albrecht, Dalton Trans. 2008, 5570-5576; c) S. Sabater, J. A. Mata and E. Peris, Organometallics 2012, 31, 6450-6456; d) R. Sakamoto, T. Kambe, S. Tsukada, K. Takada, K. Hoshiko, Y. Kitagawa, M. Okumura and H. Nishihara, Inorg. Chem. 2013, 52, 7411-7416.

[24] a) R. Ballardini, G. Varani, M. T. Indelli and F. Scandola, Inorg. Chem. 1986, 25, 3858-3865; b) D. Tapu, C. Owens, D. VanDerveer and K. Gwaltney, Organometallics 2009, 28, 270-276.

[25] a) R. Brehme, D. Enders, R. Fernandez and J. M. Lassaletta, Eur. J. Org. Chem. 2007, 5629-5660; b) P. Tian, H.-Q. Dong and G.-Q. Lin, Acs Catalysis 2012, 2, 95-119. 
[26] a) K. Fagnou and M. Lautens, Chem. Rev. 2003, 103, 169-196; b) T. Hayashi and K. Yamasaki, Chem. Rev. 2003, 103, 2829-2844; c) L. Zhao, Y. Ma, F. He, W. Duan, J. Chen and C. Song, J. Org. Chem. 2013, 78, 1677-1681; d) V. Lillo, A. Prieto, A. Bonet, M. M. Diaz-Requejo, J. Ramirez, P. J. Perez and E. Fernandez, Organometallics 2009, 28, 659-662.

[27] T. Jerphagnon, M. G. Pizzuti, A. J. Minnaard and B. L. Feringa, Chem. Soc. Rev. 2009, 38, 1039-1075.

[28] H. J. Edwards, J. D. Hargrave, S. D. Penrose and C. G. Frost, Chem. Soc. Rev. 2010, 39, 2093-2105.

[29] B. J. Truscott, G. C. Fortman, A. M. Z. Slawin and S. P. Nolan, Org. Biomol. Chem. 2011, 9, 7038-7041.

[30] a) M. Pucheault, S. Darses and J. P. Genet, Tetrahedron Lett. 2002, 43, 61556157; b) M. Pucheault, S. Darses and J. P. Genet, Eur. J. Org. Chem. 2002, 35523557; c) M. Sakai, H. Hayashi and N. Miyaura, Organometallics 1997, 16, 42294231; d) T. Hayashi, M. Takahashi, Y. Takaya and M. Ogasawara, J. Am. Chem. Soc. 2002, 124, 5052-5058; e) I. Penafiel, I. M. Pastor, M. Yus, M. A. Esteruelas and M. Olivan, Organometallics 2012, 31, 6154-6161; f) I. Bratko, G. GuisadoBarrios, I. Favier, S. Mallet-Ladeira, E. Teuma, E. Peris and M. Gómez, Eur. J. Org. Chem. 2014, 2160-2167.

[31] a) B. Helms and J. M. J. Frechet, Adv. Synth. Catal. 2006, 348, 1125-1148; b) D. Astruc, C. R. Chimie 2005, 8, 1101-1107; c) J. N. H. Reek, S. Arevalo, R. Van Heerbeek, P. C. J. Kamer and P. Van Leeuwen in Dendrimers in catalysis, Vol. 49 2006, pp. 71-151.

[32] G. Guisado-Barrios, J. Hiller and E. Peris, Chem. Eur. J. 2013, 19, 10405-10411. 



\section{Chapter 3}

\section{Homoleptic and Heteroleptic}

Coordination Cages with NHC and

MIC Ligands 



\subsection{Introduction}

In 1987, Lehn and co-workers described the preparation of a dinuclear helicate complex by reacting $\mathrm{Cu}^{(\mathrm{I})}$-based precursors with 2,2-bipyridine, ${ }^{[1]}$ a work that constituted the first example of a metal-directed self-assembly process. A few years later, Constable defined metallo-supramolecular chemistry as 'the chemistry involving the combination of bridging organic ligands with metal units to synthesize discrete or polymeric assemblies.' ${ }^{[2]}$ Hence, the basis for metallosupramolecular design is the availability of (often rigid) ligands with two or more binding sites that must be able to combine with suitable metal fragments to form symmetrical structures with a variety of shapes and sizes. Nowadays, a large number of self-assembly metallosupramolecular structures featuring different shapes, sizes and properties are associated with the names of Fujita, ${ }^{[3]}$ Raymond, ${ }^{[4]}$ Stang, ${ }^{[5]}$ Nitschke ${ }^{[6]}$ and Constable, ${ }^{[7]}$ among others. ${ }^{[8]}$ Most efforts in the design of metallosupramolecules are based on mimicking enzymes, and therefore well-defined hydrophobic cavities are pursued, but again, the design of biomimetic complexes relies on the synthesis of metal complexes with polydentate ligands that mimic the environment found in nature. For the formation of the cavities an array of several metals is needed, and this is the reason why metallorganic molecules with cavities (metallocavitands) have been defined as 'multimetallic complexes where the metal coordination is necessary for cavity formation' ${ }^{[9]}$

The construction of metallosupramolecular structures can be achieved by using multitopic ligands bearing two or more binding domains separated by spacers which, by combination with the suitable metal fragments, may form assemblies with various sizes and geometries. ${ }^{[6 a, b, 7 b, 10]}$ In this context, extended poly-N-heterocyclic-carbene (NHC) ligands ${ }^{[11]}$ have recently shown to be suitable scaffolds for the preparation of supramolecular assemblies. The topological diversity of poly-NHCs has allowed the preparation of a variety of supramolecular assemblies that include molecular squares and triangles, ${ }^{[12]}$ cylinder-like structure ${ }^{[13]}$ and organometallic polymers. ${ }^{[14]}$

The $\mathrm{Ag}^{(\mathrm{I})}$-mediated self-assembly of supramolecular assemblies from poly-NHC ligands has developed an emerging field of organometallic chemistry due to their facile preparation. ${ }^{[15]} \mathrm{Ag}^{(\mathrm{I})}-\mathrm{NHC}$ complexes are readily obtained reacting $\mathrm{Ag}_{2} \mathrm{O}$ with the corresponding NHC precursor (normally an imidazolium salt). In addition, they can easily be converted into different metal complexes via transmetalation reactions. This methodology has permitted the preparation of the cylinder-like assemblies with three 
(I), four (II) and even six metal centers (III) (Chart 3.1). However, these molecular assemblies derived from NHC substituted phenylenes feature a rather small cavity, limiting the incorporation of guests. Therefore, the development of new supramolecular assemblies based on poly-NHC ligands having a larger $\pi$-conjugated framework could allow the preparation of novel structures, and also facilitate the recognition of guests.

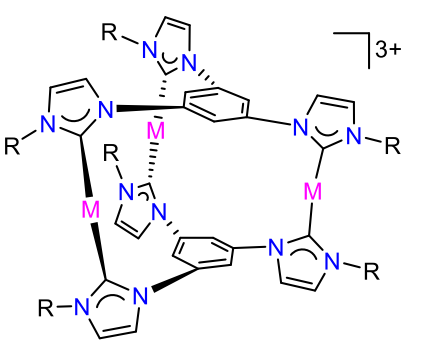

I

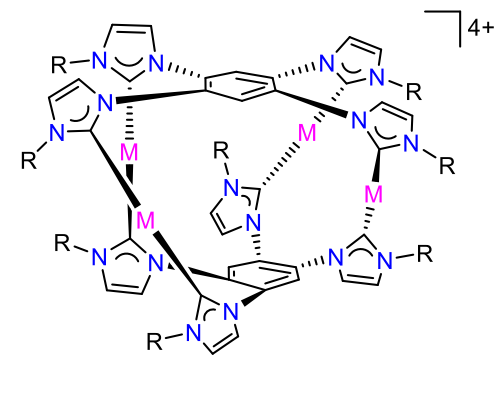

II

$\mathrm{M}=\mathrm{Ag}, \mathrm{Au}, \mathrm{R}=n-\mathrm{Bu}, \mathrm{Et}$

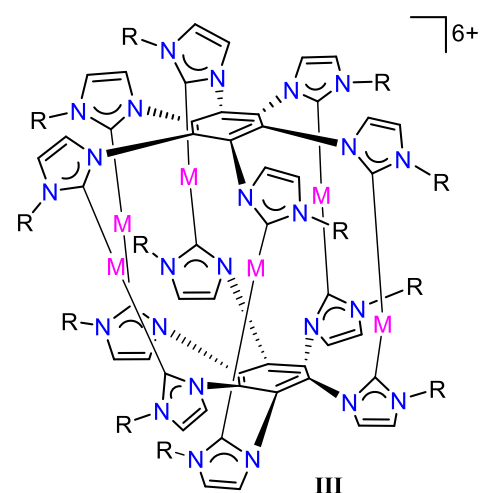

Chart 3.1. Cylinder-like assemblies from benzene derived tris-, tetra- or hexa-NHC ligands

We thought that we could apply our expertise in the preparation of rigid poly-NHC ${ }^{[16]}$ and poly-MIC ${ }^{[17]}$ ligands for the design of novel metallo-organic macromolecular cylinders. Self-assembled cages based on mesoionic carbenes are especially interesting, because they were not reported prior to this work. Such structures may offer some advantages and intriguing chemical properties, and they may be potentially useful for the selective recognition of small neutral or ionic molecules. ${ }^{[9 c, 18]}$ This Chapter deals with the preparation of several homoleptic and heteroleptic coordination cages based on tris-NHC and tris-MIC ligands and the study of their reactivity.

\subsection{Results and discussion}

\subsubsection{Synthesis and characterization of homoleptic compounds}

In this section we will describe the preparation of homoleptic nanometer-sized cylinderlike assemblies with coinage metals (Chart 3.2) derived from the 1,3,5-triphenylbenzene bridged tris-imidazolium and tris-triazolium salts in Chapter 2. ${ }^{[13 \mathrm{~g}, 19]}$ In addition, the synthesis and reactivity of heteroleptic coordination cages of $\mathrm{Ag}^{(\mathrm{I})}$ will also be described. 

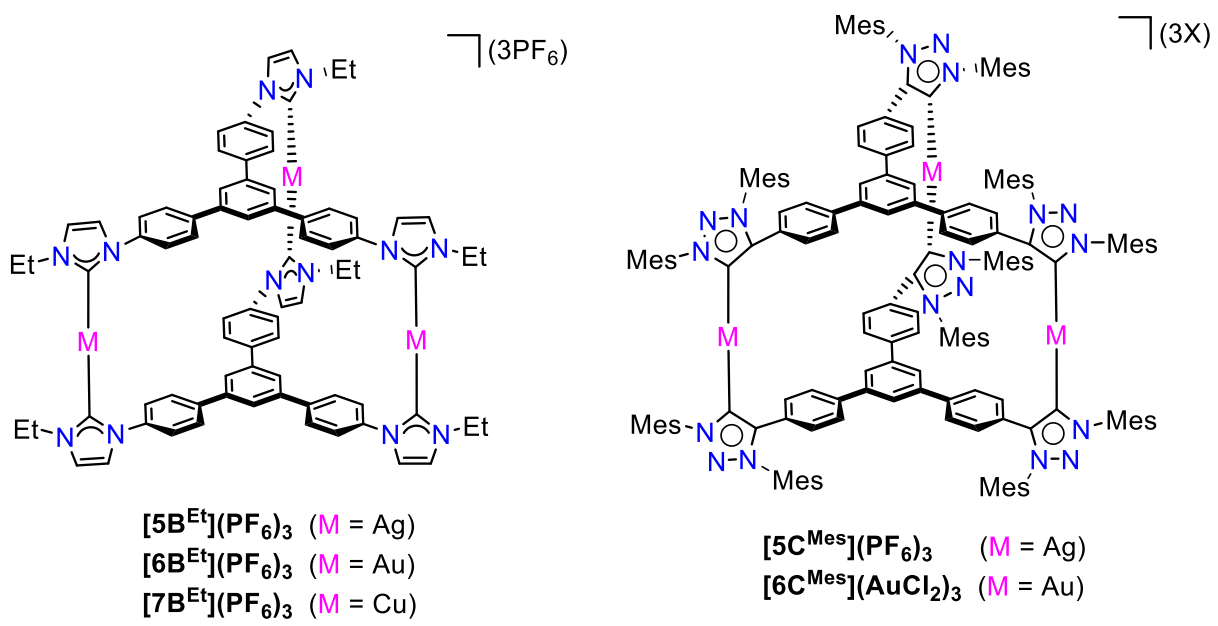

Chart 3.2. Cylinder-like assemblies from triphenylbenzene tris-NHC and tris-MIC ligands

\subsubsection{Tris-NHC metallacages}

The following work is a result of a collaboration between the group of Prof. Ekkehardt Hahn (Münster, Germany) and our research group in Castellón. The tris-imidazolium salt $\left[\mathbf{H}_{3} \mathbf{B}^{\mathrm{Et}}\right]\left(\mathbf{P F}_{6}\right)_{\mathbf{3}}$ (Scheme 3.1) described in Chapter 2 was employed as ligand precursor. Scheme 3.1 displays the synthetic procedure for the preparation of the selfassembly structures of $\mathrm{Ag}, \mathrm{Au}$ and $\mathrm{Cu}$. The reaction of 2 equiv. of $\left[\mathbf{H}_{\mathbf{3}} \mathbf{B}^{\mathrm{Et}}\right]\left(\mathbf{P F}_{\mathbf{6}}\right)_{3}$ with 3 equiv. of $\mathrm{Ag}_{2} \mathrm{O}$ in acetonitrile at $60{ }^{\circ} \mathrm{C}$ under the exclusion of light afforded the homoleptic trinuclear $\mathrm{Ag}^{(\mathrm{I})}-\mathrm{NHC}$ cage complex $\left[\mathbf{5 B}^{\mathrm{Et}}\right]\left(\mathbf{P F}_{\mathbf{6}}\right)_{3}$ in $77 \%$ yield, as a white solid.

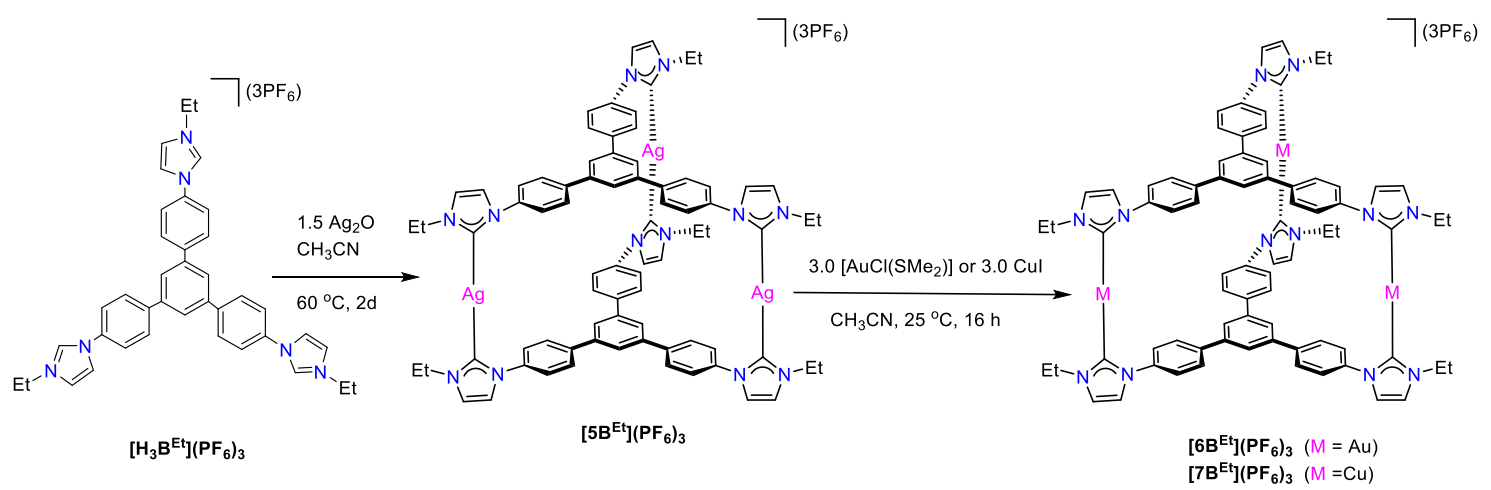

Scheme 3.1. Synthesis of complex $\left[\mathbf{5 B}^{\mathrm{Et}}\right]\left(\mathrm{PF}_{6}\right)_{3}$ and transmetalation to $\left[\mathbf{6 B}^{\mathrm{Et}}\right]\left(\mathrm{PF}_{6}\right)_{3}$ and $\left[\mathbf{7 B}^{\mathrm{Et}}\right]\left(\mathrm{PF}_{6}\right)_{3}$ complexes

Since $\mathrm{Ag}^{(\mathrm{I})}-\mathrm{NHC}$ complexes are good carbene transfer agents, ${ }^{[15]}$ we replaced the $\mathrm{Ag}^{(\mathrm{I})}$ ions in $\left[\mathbf{5 B}^{\mathrm{Et}}\right]\left(\mathbf{P F}_{\mathbf{6}}\right)_{3}$ by $\mathrm{Au}^{(\mathrm{I})}$ by stirring a solution of $\left[\mathbf{5 B}^{\mathrm{Et}}\right]\left(\mathbf{P F}_{\mathbf{6}}\right)_{3}$ in acetonitrile with 3 
equiv. of $\left[\mathrm{AuCl}\left(\mathrm{SMe}_{2}\right)\right]$ for $16 \mathrm{~h}$ at room temperature. This reaction allowed the formation of the trinuclear $\mathrm{Au}^{(\mathrm{I})}$ hexacarbene complex $\left[\mathbf{6 B}^{\mathrm{Et}}\right]\left(\mathbf{P F}_{6}\right)_{3}$ as an air- and moisture-stable white solid, in $70 \%$ yield.

Similarly, the transmetalation of the tris- $\mathrm{Ag}^{(\mathrm{I})}-\mathrm{NHC}$ complex $\left[\mathbf{5 B}^{\mathrm{Et}}\right]\left(\mathbf{P F}_{\mathbf{6}}\right)_{\mathbf{3}}$ with 3 equiv. of $\mathrm{CuI}$ in acetonitrile at room temperature yielded the trinuclear $\mathrm{Cu}^{(\mathrm{I})}$ hexacarbene complex $\left[\mathbf{7 B}^{\mathrm{Et}}\right]\left(\mathbf{P F}_{\mathbf{6}}\right)_{3}$, as a white solid in $64 \%$ yield. The reaction allowed the retention of the metallosupramolecular structure.

All compounds were characterized by NMR spectroscopy, mass spectrometry and elemental analysis. All details regarding the characterization of compounds $\left[\mathbf{6 B}^{\mathrm{Et}}\right]\left(\mathbf{P F}_{\mathbf{6}}\right)_{3}$ and $\left[\mathbf{7 B}^{\mathrm{Et}}\right]\left(\mathbf{P F}_{6}\right)_{3}$ can be found in the Experimental Section (Chapter 5). Probably, the most relevant features of their NMR characterization arise from the appearance of the signal due to the metallated carbons in the ${ }^{13} \mathrm{C}\left\{{ }^{1} \mathrm{H}\right.$ NMR spectra, at $\left(\left[\mathbf{5 B}^{\mathrm{Et}}\right]\left(\mathbf{P F}_{\mathbf{6}}\right)_{3}: 178.3\right.$ ppm; $\left[\mathbf{6 B}^{\mathrm{Et}}\right]\left(\mathbf{P F}_{\mathbf{6}}\right)_{3}$ : $180.6 \mathrm{ppm}$; $\left[\mathbf{7 B}^{\mathrm{Et}}\right]\left(\mathbf{P F}_{\mathbf{6}}\right)_{3}$ : $\left.174.3 \mathrm{ppm}\right)$. As an illustrative example, the ${ }^{1} \mathrm{H}$ NMR spectrum of $\left[\mathbf{5 B}^{\mathrm{Et}}\right]\left(\mathbf{P F}_{\mathbf{6}}\right)_{\mathbf{3}}$ is described below.

\section{${ }^{1} H$ NMR spectrum of $\left[\mathbf{5} \boldsymbol{B}^{E t}\right]\left(\boldsymbol{P F}_{\mathbf{6}}\right)_{3}$}

Figure 3.1 shows the ${ }^{1} \mathrm{H}$ NMR spectrum of $\left[\mathbf{5 B}^{\mathbf{E t}}\right]\left(\mathbf{P F}_{\mathbf{6}}\right)_{3}$. The signals attributed to the protons of the $\mathrm{CH}$ groups of the imidazolylidenes are shown at 7.99 and 7.87 ppm (c and $\mathbf{d}$ ). The signals corresponding to the protons of 1,3,5-triphenylbenzene core (e, $\mathbf{f}$ and $\mathbf{g}$ ) are displayed at 7.79 and $7.65 \mathrm{ppm}$. The signals due to the protons of the six ethyl groups appear at 4.43 and $1.61 \mathrm{ppm}$ (b and a, for the $\mathrm{CH}_{2}$ and $\mathrm{CH}_{3}$ groups, respectively).

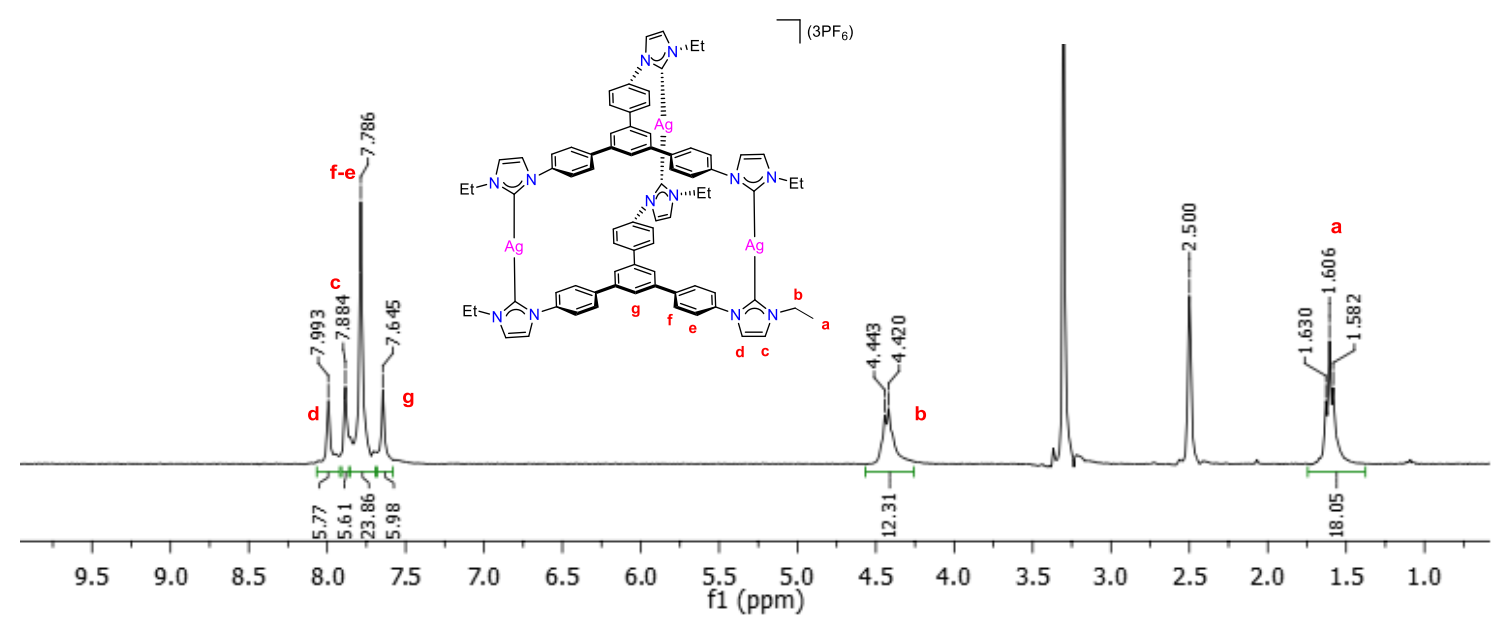

Figure 3.1. ${ }^{1} \mathrm{H}$ NMR spectrum of $\left[\mathbf{5 B}^{\mathrm{Et}}\right]\left(\mathbf{P F}_{\mathbf{6}}\right)_{3}$ in DMSO- $d^{6}$ 


\section{Molecular structures of $\left[\mathbf{6 B}^{E t}\right]\left(\boldsymbol{P F}_{\mathbf{6}}\right)_{3}$}

Single crystals of the gold-cage $\left[\mathbf{6 B}^{\mathrm{Et}}\right]\left(\mathbf{P F}_{\mathbf{6}}\right)_{3}$ suitable for an X-ray diffraction study were obtained by slow vapor diffusion of diethyl ether into a saturated acetonitrile solution of the compound. The structure revealed two tris-NHC ligands sandwiching the three $\mathrm{Au}^{(\mathrm{I})}$ atoms (Figure 3.2).

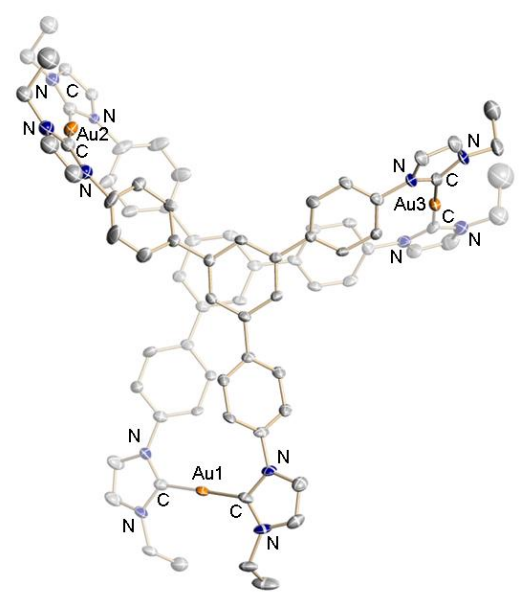

Figure 3.2. Molecular structure (top view) of trication $\left[6 \mathbf{B}^{\mathrm{Et}}\right]^{3+}$ in $\left[6 \mathbf{B}^{\mathrm{Et}}\right]\left(\mathbf{P F}_{6}\right)_{3} \cdot \mathrm{CH}_{3} \mathrm{CN} \cdot 5 \mathrm{Et} \mathrm{H}_{2} \mathrm{O}$ (hydrogen atoms, counterion and solvent molecules have been omitted for clarity, 50\% probability ellipsoids)

Table 3.1. Selected range bond lengths and angles of complex $\left[\mathbf{6 B}^{\mathrm{Et}}\right]\left(\mathbf{P F}_{\mathbf{6}}\right)_{3}$

\begin{tabular}{|c|c|c|c|}
\hline \multicolumn{2}{|c|}{ Bond lengths ( $\AA$ ) } & \multicolumn{2}{|c|}{ Bond angles $\left(^{\circ}\right)$} \\
\hline \multirow[t]{2}{*}{$\mathrm{Au}(1)-\mathrm{C}_{\mathrm{NHC}}$} & $1.918(14)-2.096(14)$ & $\mathrm{N}-\mathrm{C}_{\mathrm{NHC}}-\mathrm{N}$ & $101.5(10)-105.1(12)$ \\
\hline & & $\mathbf{C}_{\text {NHC }}-\mathbf{A u}-\mathbf{C}_{\mathrm{NHC}}$ & $170.5(7)-178.6(5)$ \\
\hline
\end{tabular}

The metric parameters observed in cation $\left[\mathbf{6 B}^{\mathrm{Et}}\right]^{3+}\left[\mathrm{Au}-\mathrm{C}_{\mathrm{NHC}}, 1.918(14)-2.096(14) \AA\right.$;

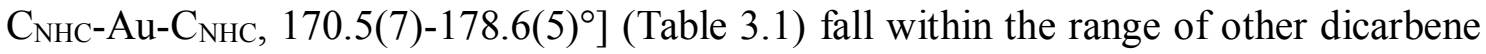
gold complexes reported in the literature. ${ }^{[12 \mathrm{e}, 13 \mathrm{f}, 20]}$ The three gold atoms form a triangle featuring $\mathrm{Au} \cdots \mathrm{Au}$ separations of about $1.4 \mathrm{~nm}$. The two central phenyl rings of the trisNHC ligands are oriented in a nearly coplanar fashion where the separation between the two centroids is about $3.644 \AA$. We take this short separation as an indication for the presence of $\pi \cdots \pi$ interactions between these rings. Related trinuclear cylinder-like assemblies obtained from tris-NHC ligands only linked by a phenylene group (see Chart 3.1) feature a much longer separation of the midpoints of the phenylene groups $(\mathrm{M}=$ Ag: $4.914 \AA ; M=A u: 4.762 \AA ; M=C u: 4.239 \AA) .{ }^{[13 e]}$ The convex distortion of $\left[\mathbf{6 B}^{\mathrm{Et}}\right]\left(\mathbf{P F}_{\mathbf{6}}\right)_{3}$ is only possible with the 1,3,5-triphenylbenzene core. In addition, the NHC 
donors are not oriented perpendicular to the aromatic backbone also contributing to the short separation of the central phenylene rings.

By assuming the molecule to adopt a pseudo-triangular prismatic structure, we may estimate the internal volume of the cavity as $360 \AA^{3}$, which is significantly larger than the volume estimated for the previously reported tri- $\mathrm{Au}^{(\mathrm{I})}$ structures by Hahn and coworkers $^{[13 \mathrm{c}, \mathrm{e}]}$ (the volume of the cavity of this previously reported structure is estimated as $72 \AA^{3}$ ) (see Chart 3.1, I). To accommodate the $\mathrm{C}_{\mathrm{NHC}}-\mathrm{Au}-\mathrm{C}_{\mathrm{NHC}}$ bonds of about $4.0 \AA$, the imidazolium rings are pushed out of the plane of the central phenyl group towards the outside of the cylinder giving the tris-carbene a convex geometry (Figure 3.3)

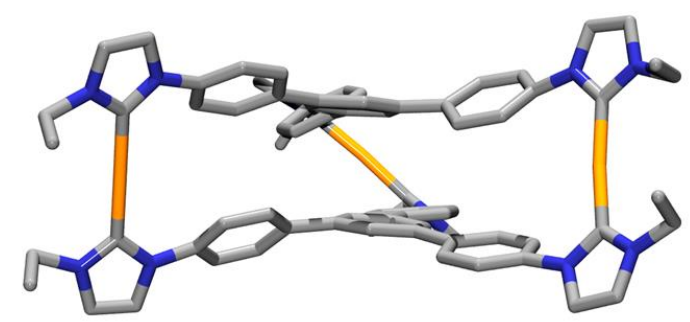

Figure 3.3. Schematic representation of the molecular structure (side view) of cation $\left[\mathbf{6 B}^{\mathrm{Et}}\right]\left(\mathbf{P F}_{6}\right)_{3}$ showing the the $\pi \cdots \pi$ interactions between the two central phenyl rings and the non-planar geometry of the tris-carbene ligands.

\subsubsection{Tris-MIC metallacages}

Parallel to the rapid growth of NHCs, mesoionic carbenes (MICs) ${ }^{[21]}$ have recently emerged as a powerful subclass of NHCs due to their ease of accessibility and their arguably stronger electron donor properties compared to the classical NHCanalogues. ${ }^{[22]}$ While monometallic complexes bearing mono-MIC ligands are widely used, poly-MIC ligands are not common, ${ }^{[17,23]}$ and this explains why MIC-based supramolecular assemblies were unknown before we started our work in the field.

The synthesis and characterization of the tris-triazolium salt $\left.\left[\mathbf{H}_{3} \mathbf{C}^{\mathbf{M e s}}\right]_{(\mathbf{P F}}\right)_{3}$ (Scheme 3.2) was described in Chapter 2. The reaction of $\left[\mathbf{H}_{3} \mathbf{C}^{\mathbf{M e s}}\right]\left(\mathbf{P F}_{\mathbf{6}}\right)_{3}$ with 1.5 equivalents of $\mathrm{Ag}_{2} \mathrm{O}$ in $\mathrm{MeOH}$ at $60{ }^{\circ} \mathrm{C}$, afforded the tris- $\mathrm{Ag}^{(\mathrm{I})}-\mathrm{MIC}$-cage $\left[\mathbf{5 C}^{\mathbf{M e s}}\right]\left(\mathbf{P F}_{\mathbf{6}}\right)_{3}$ in $42 \%$ yield. Compound $\left[\mathbf{H}_{3} \mathbf{C}^{\mathbf{M e s}}\right]\left(\mathbf{P F}_{6}\right)_{3}$ is the first MIC-based self-assembly structure reported to date. 


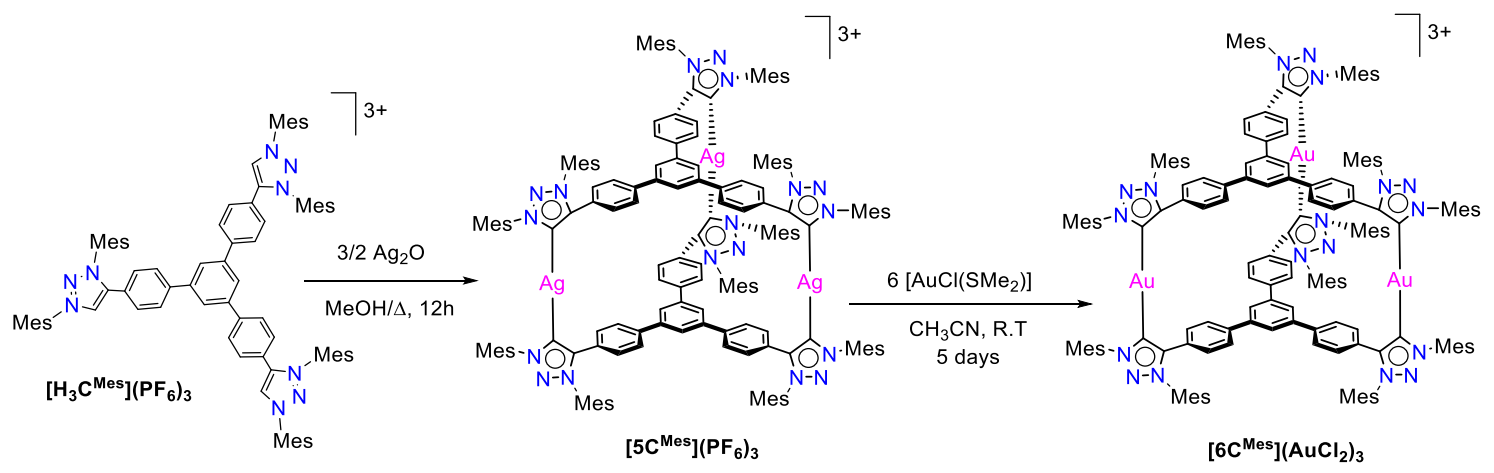

Scheme 3.2. Synthesis of $\left[5 \mathrm{C}^{\mathrm{Mes}}\right]\left(\mathrm{PF}_{6}\right)_{3}$ and $\left[6 \mathrm{C}^{\mathrm{Mes}}\right]\left(\mathrm{AuCl}_{2}\right)_{3}$

The reaction of $\left[\mathbf{5 C}^{\mathrm{Mes}}\right]\left(\mathbf{P F}_{\mathbf{6}}\right)_{3}$ with six equivalents of $\left[\mathrm{AuCl}\left(\mathrm{SMe}_{2}\right)\right]$ in acetonitrile at room temperature during 5 days, led to the formation of the trinuclear hexa-MIC complex $\left[\mathbf{6 C}^{\mathrm{Mes}}\right]\left(\mathbf{A u C l}_{2}\right)_{3}$, as an air-stable white solid, in $63 \%$ yield. The use of the excess of $\mathrm{Au}$ explains the formation of $\left[\mathbf{6 C}^{\mathrm{Mes}}\right]\left(\mathbf{A u C l}_{2}\right)_{3}$ with three $\left(\mathrm{AuCl}_{2}\right)^{-}$counteranions.

Compounds $\left[\mathbf{5 C}^{\mathrm{Mes}}\right]\left(\mathbf{P F}_{\mathbf{6}}\right)_{3}$ and $\left[\mathbf{6 C}^{\mathrm{Mes}}\right]\left(\mathbf{A u C l}_{\mathbf{2}}\right)_{3}$ were characterized by means of NMR spectroscopy, mass spectrometry and elemental analysis. All the details regarding the characterization of compound $\left[\mathbf{6 C}^{\mathrm{Mes}}\right]\left(\mathbf{A u C l}_{2}\right)_{3}$ can be found in the Experimental Section (Chapter 5).

The ${ }^{13} \mathrm{C}\left\{{ }^{1} \mathrm{H}\right\}$ NMR spectrum of $\left[\mathbf{5 C}^{\mathbf{M e s}}\right]\left(\mathbf{P F}_{\mathbf{6}}\right)$ shows the resonance due to the equivalent metallated carbene-carbon atoms at 169.7 ppm, exhibiting the coupling to both silver isotopes $\left({ }^{1} J_{\mathrm{C}-\mathrm{Ag}(107)}=165.0 \mathrm{~Hz},{ }^{1} J_{\mathrm{C}-\mathrm{Ag}(109)}=190.5 \mathrm{~Hz}\right)$. The ${ }^{13} \mathrm{C}\left\{{ }^{1} \mathrm{H}\right\}$ NMR spectrum of $\left[\mathbf{6 C}^{\mathrm{Mes}}\right]\left(\mathbf{A u C l}_{2}\right)_{3}$ shows a single signal at $161.1 \mathrm{ppm}$. As an illustrating example of the NMR characterization of the compounds, the ${ }^{1} \mathrm{H}$ NMR spectrum of $\left[\mathbf{5 C}^{\mathbf{M e s}}\right]\left(\mathbf{P F}_{\mathbf{6}}\right)_{3}$ is described below.

\section{${ }^{1} H$ NMR spectrum of $\left[\mathbf{5} \boldsymbol{C}^{\text {Mes }}\right]\left(\boldsymbol{P F}_{\mathbf{6}}\right)_{3}$}

The ${ }^{1} \mathrm{H}$ NMR spectrum of $\left[\mathbf{5 C}^{\mathbf{M e s}} \mathbf{~}_{(\mathbf{P F}}\right)_{3}$ (Figure 3.4 ) indicates that the compound is highly symmetric, as shown by the appearance of four signals due to the protons of the methyl at the mesityl groups (four signals with relative integrals 18:18:36:36). The absence of the signal due to the acidic protons of the NHCC groups, provides a preliminary indication that the coordination of $\left[\mathbf{H}_{3} \mathbf{C}^{\mathbf{M e s}}\right]\left(\mathbf{P F}_{\mathbf{6}}\right)_{3}$ to $\mathrm{Ag}^{(\mathrm{I})}$ has occurred. The signals assigned to the protons of the 1,3,5-triphenylbenzene core (a, $\mathbf{c}$ and $\mathbf{b}$ ) are displayed at 7.52, 7.43 and $7.36 \mathrm{ppm}$, respectively. The signals due to the aromatic 
protons of the mesityl groups appear at 7.05 and $7.00 \mathrm{ppm}$, and those due to the methyl groups appear as four singlets between 2.04 and $2.54 \mathrm{ppm}$.

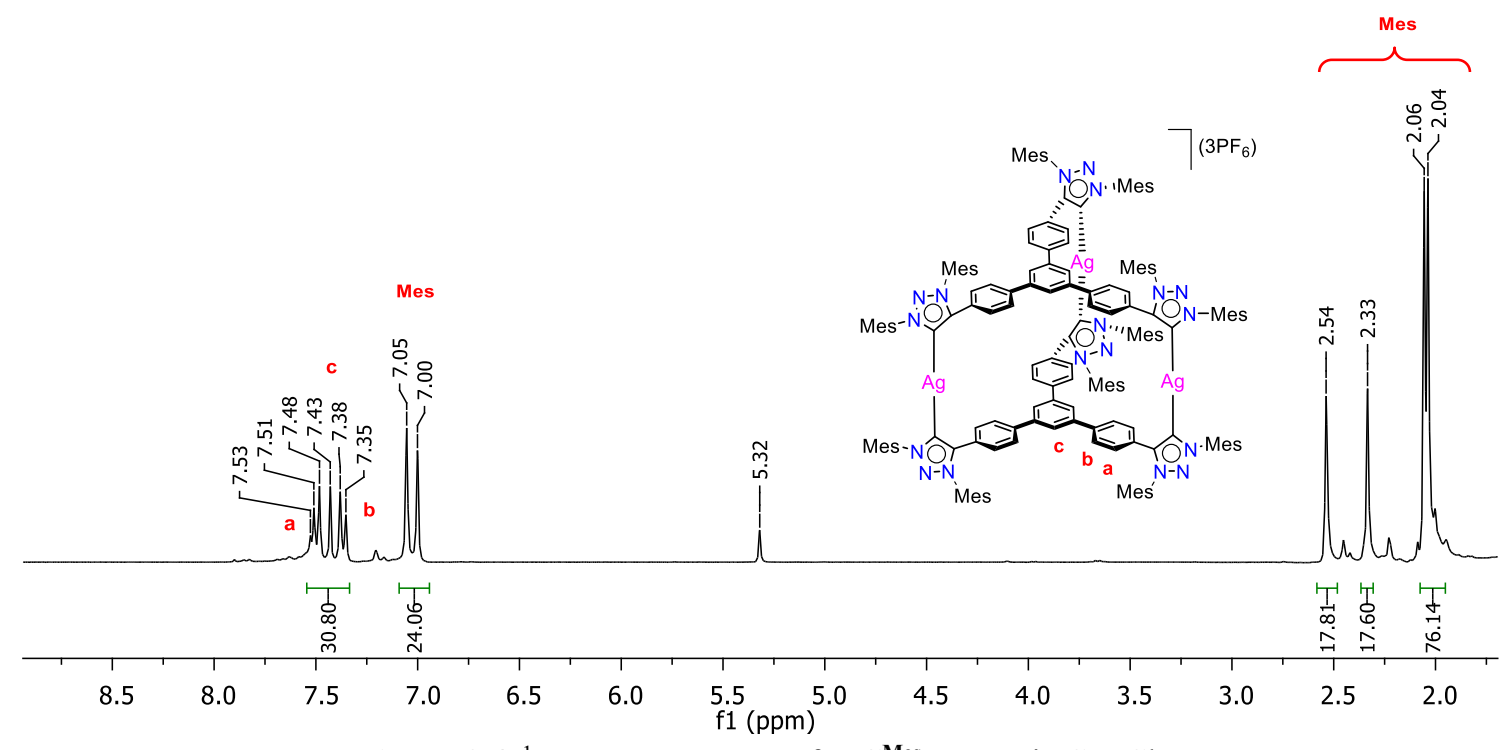

Figure 3.4. ${ }^{1} \mathrm{H}$ NMR spectrum of $\left[\mathbf{5 C}^{\mathrm{Mes}}\right]\left(\mathbf{P F}_{6}\right)_{3}$ in $\mathrm{CD}_{2} \mathrm{Cl}_{2}$

\section{Molecular structure of [5C $\left.\boldsymbol{C}^{\mathrm{Mes}}\right]\left(\boldsymbol{P F}_{\mathbf{6}}\right)_{3}$}

The molecular structure of $\left[\mathbf{5 C}^{\mathrm{Mes}}\right]\left(\mathbf{P F}_{\mathbf{6}}\right)_{3}$ was confirmed by X-ray diffraction studies (Figure 3.5). The structure consists of two tris-MIC ligands sandwiching the three silver atoms, thus rendering a hexacarbene complex cation, with three $\mathrm{PF}_{6}{ }^{-}$counter-anions.

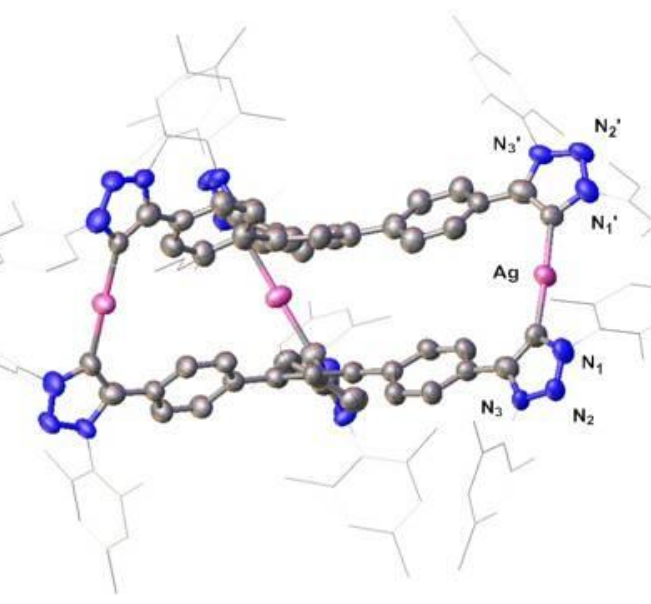

Figure 3.5. Molecular structure of complex $\left[\mathbf{5 C}^{\mathrm{Mes}}\right]\left(\mathbf{P F}_{\mathbf{6}}\right)_{3}$ from different views (hydrogen atoms and counterions $\left(3 \mathrm{PF}_{6}^{-}\right)$omitted for clarity. Mesityl groups are represented as wireframes for clarity. Ellipsoids at $50 \%$ of probability.

The average distance of the $\mathrm{Ag}-\mathrm{C}_{\text {MIC }}$ bonds is 2.105(7) $\AA$, and the $\mathrm{C}_{\mathrm{MIC}}-\mathrm{Ag}-\mathrm{C}_{\mathrm{MIC}}$ angle is $177.0^{\circ}$. The distance between the two central phenylene rings is of $4.318 \AA$. The three 
silver atoms form a triangle, with an average Ag-Ag separation of about $13.96 \AA$. (Table 3.2)

Table 3.2. Selected bond lengths and angles of complex $\left[\mathbf{5 C}^{\mathrm{Mes}}\right]\left(\mathbf{P F}_{\mathbf{6}}\right)_{3}$

\begin{tabular}{lrrr}
\hline \multicolumn{2}{c}{ Bond lengths $(\AA)$} & \multicolumn{2}{c}{ Bond angles $\left(^{\circ}\right)$} \\
\hline $\operatorname{Ag}(1)-\mathrm{C}_{5}$ & $2.113(7)$ & $\mathbf{N}_{\mathbf{1}}-\mathbf{C}_{\mathbf{5}}-\mathbf{N}_{\mathbf{4}}$ & $101.4(6)$ \\
$\operatorname{Ag}(1)-\mathrm{C}_{5}$, & $2.097(7)$ & $\mathbf{N}_{\mathbf{1}},-\mathbf{C}_{5},-\mathbf{N}_{\mathbf{4}}$, & $103.5(6)$ \\
& & $\mathbf{C}_{\mathbf{5}}-\mathbf{A g}-\mathbf{C}_{\mathbf{5}}$, & $177.9(3)$ \\
\hline
\end{tabular}

\subsubsection{Synthesis and characterization of a MIC-NHC mixed metallacage}

Albrecht and Cazin recently described a methodology for the preparation of heteroleptic metal complexes based on coinage metals featuring either two bis-MIC or bis-NHC ligands. ${ }^{[21 c, 24]}$ Interestingly, the spontaneous recombination of MIC-ligands in the presence of silver salts allowed the preparation of bis-MIC-Au complexes. ${ }^{[24]}$ Due to the similarities between NHC and MIC ligands and their complex-cage derivatives, we decided to see if we could obtain a cylinder-type coordination complex combining the presence of both, tris-NHC and tris-MIC ligands. The preparation of such type of complex is very interesting because it would allow us to design a methodology for obtaining coordination cages with two different types of carbenes. In order to prepare this heteroleptic cage, we decided to directly react an equimolecular amount of the trisazolium salts $\left[\mathbf{H}_{3} \mathbf{C}^{\mathrm{Mes}}\right]\left(\mathbf{P F}_{6}\right)_{3}$ and $\left[\mathbf{H}_{3} \mathbf{B}^{\mathrm{Et}}\right]\left(\mathbf{P F}_{6}\right)_{3}$, in the presence of three equivalents of $\mathrm{Ag}_{2} \mathrm{O}$ in $\mathrm{MeOH}$ at $60^{\circ} \mathrm{C}$ for 12 hours (Scheme 3.3).

Assuming a random distribution of the two ligands over the three metal centers, this reaction should allow us to obtain the mixed NHC-MIC cage in 50\% yield, together with $25 \%$ of each homoleptic cage. However, our expectations were exceeded, because the mixed NHC-MIC cage was the only metal-based species detected when we analyzed the reaction products by ESI mass spectroscopy (a main peak at $m / z 1136.8$ assigned to $\left[\mathrm{M}+\mathrm{PF}_{6}\right]^{2+}$ was observed). The purification of the resulting metal complex, allowed us to obtain the mixed NHC-MIC cage $\left(\left[\mathbf{1 B}^{\mathrm{Et}} \mathbf{C}^{\mathbf{M e s}}\right]\left(\mathbf{P F}_{\mathbf{6}}\right)_{\mathbf{3}}\right)$ in $45 \%$ yield, which is very close to the yield that we should have expected for the formation of this compound, assuming a random distribution of the two ligands about the trimetallic structure (50\%), as mentioned previously. 


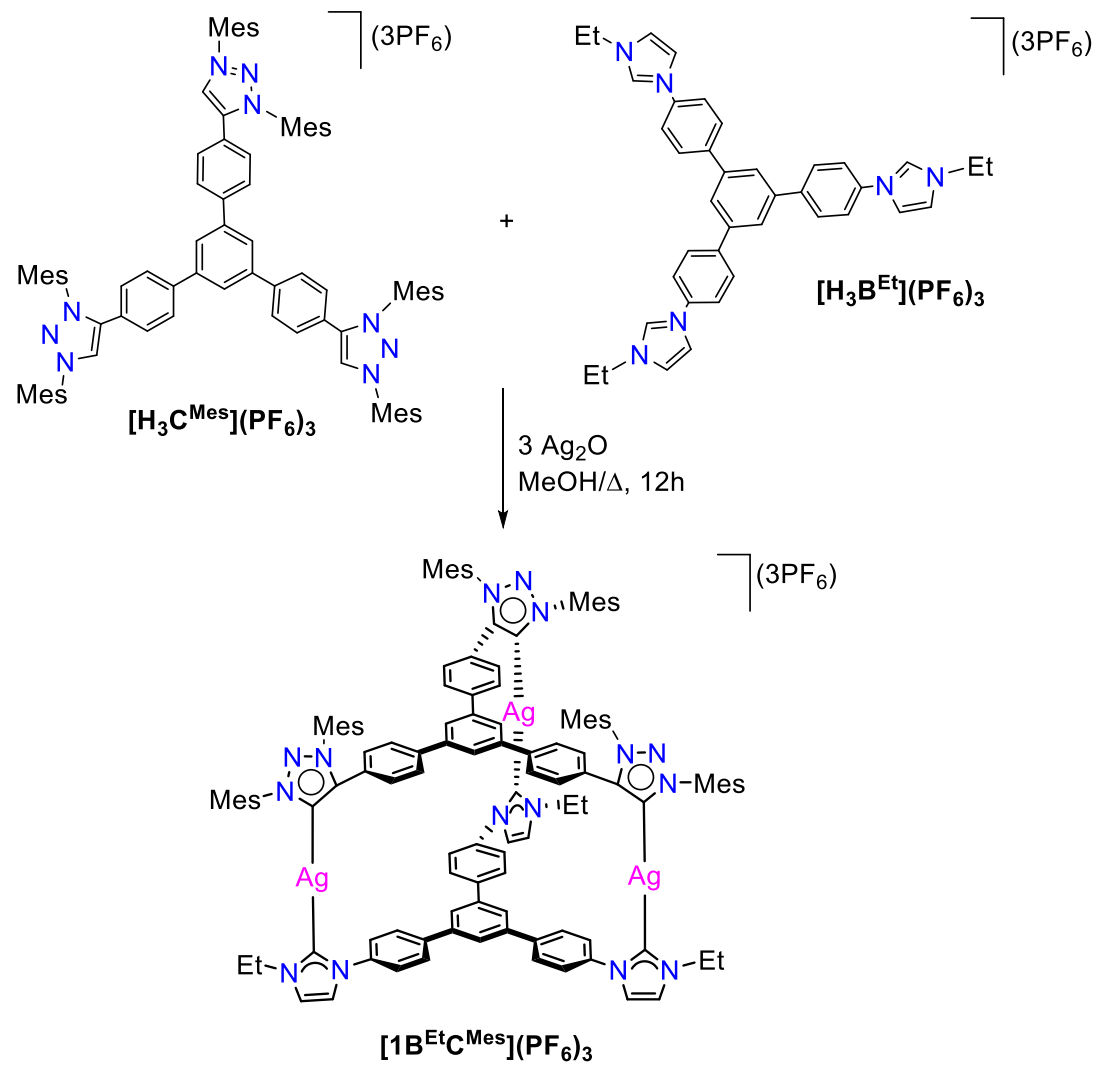

Scheme 3.3. Synthesis of $\left[\mathbf{1 B}^{\mathrm{Et}} \mathbf{C}^{\mathrm{Mes}}\right]\left(\mathbf{P F}_{\mathbf{6}}\right)_{3}$

The mixed NHC-MIC silver-based coordination cage $\left[\mathbf{1 B}^{\mathrm{Et}} \mathbf{C}^{\mathbf{M e s}}\right]\left(\mathbf{P F}_{\mathbf{6}}\right)_{\mathbf{3}}$ was characterized by NMR spectroscopy, mass spectrometry and elemental analysis.

\section{${ }^{1}$ H NMR spectrum of $\left[1 \boldsymbol{B}^{\text {Et }} \boldsymbol{C}^{\text {Mes }}\right]\left(\boldsymbol{P F}_{\mathbf{6}}\right)_{3}$}

The ${ }^{1} \mathrm{H}$ NMR spectrum of $\left[\mathbf{1 B}^{\mathrm{Et}} \mathbf{C}^{\mathrm{Mes}}\right]\left(\mathbf{P F}_{\mathbf{6}}\right)_{3}$ (Figure 3.6) revealed the presence of the two different types of tris-carbene ligands. The number of signals and their integration are consistent with the threefold symmetry of the complex.

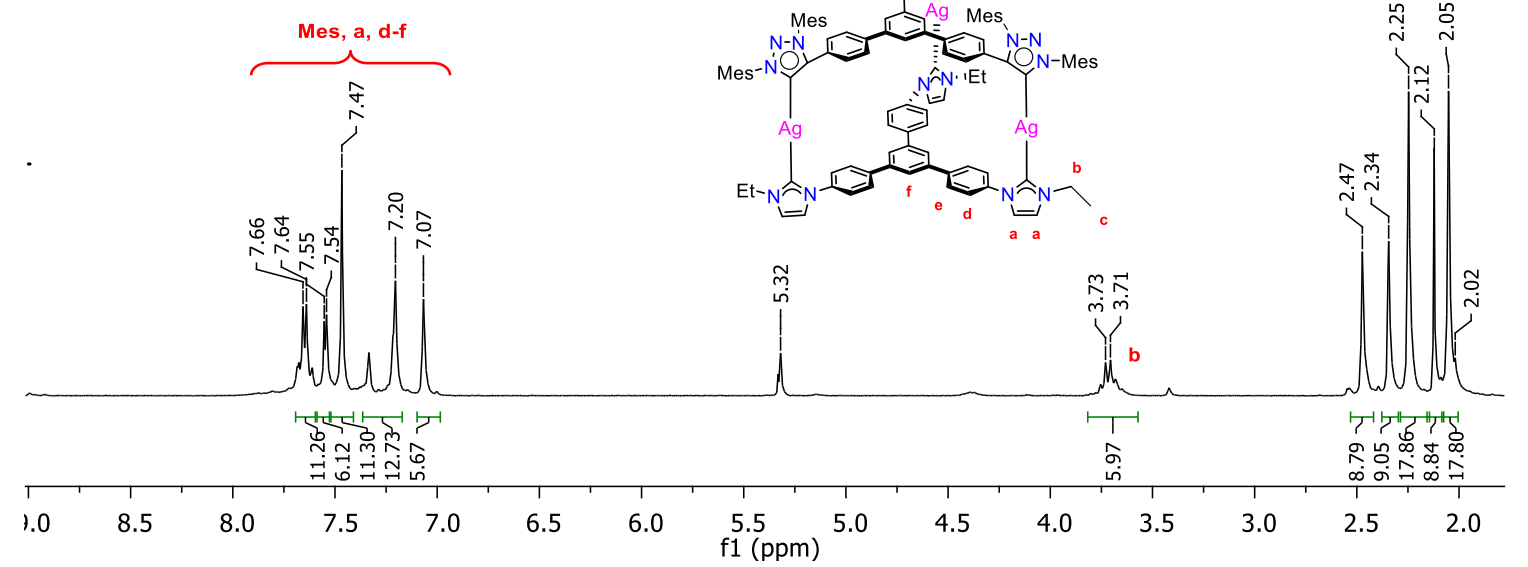

Figure 3.6. ${ }^{1} \mathrm{H}$ NMR spectrum of $\left[\mathbf{1 B}^{\mathrm{Et}} \mathbf{C}^{\mathrm{Mes}}\right]\left(\mathbf{P F}_{\mathbf{6}}\right)_{3}$ in $\mathrm{CD}_{2} \mathrm{Cl}_{2}$ 
${ }^{13} C\left\{{ }^{1} H\right\}$ NMR spectrum of $\left[1 \boldsymbol{B}^{\text {Et }} \boldsymbol{C}^{\text {Mes }}\right]\left(\boldsymbol{P F}_{\mathbf{6}}\right)_{3}$

The ${ }^{13} \mathrm{C}\left\{{ }^{1} \mathrm{H}\right\}$ NMR spectrum of $\left[\mathbf{1 B}^{\mathrm{Et}} \mathbf{C}^{\mathrm{Mes}}\right]\left(\mathbf{P F}_{\mathbf{6}}\right)_{3}$ shows the distinct signals due to the presence of the two types of carbene carbons (1) and (1'), both displaying the coupling with the two silver isotopes, and therefore appearing as four doublets, two centered at $179.5\left({ }^{1} J_{\mathrm{C}-\mathrm{Ag}(107)}=177.8 \mathrm{~Hz},{ }^{1} J_{\mathrm{C}-\mathrm{Ag}(109)}=205.5 \mathrm{~Hz}\right)$, and the other two at $169.5 \mathrm{ppm}\left({ }^{1} J_{\mathrm{C}-}\right.$ $\operatorname{Ag}(107)=177.8 \mathrm{~Hz},{ }^{1} J_{\mathrm{C}-\mathrm{Ag}(109)}=168.8 \mathrm{~Hz}$ ), for the NHC and MIC carbene carbons, respectively. These resonances are practically unshifted compared to the resonances of the di-(tris-NHC) and the di-(tris-MIC) silver complexes $\left[\mathbf{5 B}^{\mathbf{E t}}\right]\left(\mathbf{P F}_{\mathbf{6}}\right)_{\mathbf{3}}(178.3 \mathrm{ppm})$ and $\left[\mathbf{5 C}^{\mathrm{Mes}}\right]\left(\mathbf{P F}_{\mathbf{6}}\right)_{3}\left(169.7 \mathrm{ppm},{ }^{1} J_{\mathrm{C}-\mathrm{Ag}(107)}=165.0 \mathrm{~Hz},{ }^{1} J_{\mathrm{C}-\mathrm{Ag}(109)}=190.5 \mathrm{~Hz}\right){ }^{[13 \mathrm{~g}]}$

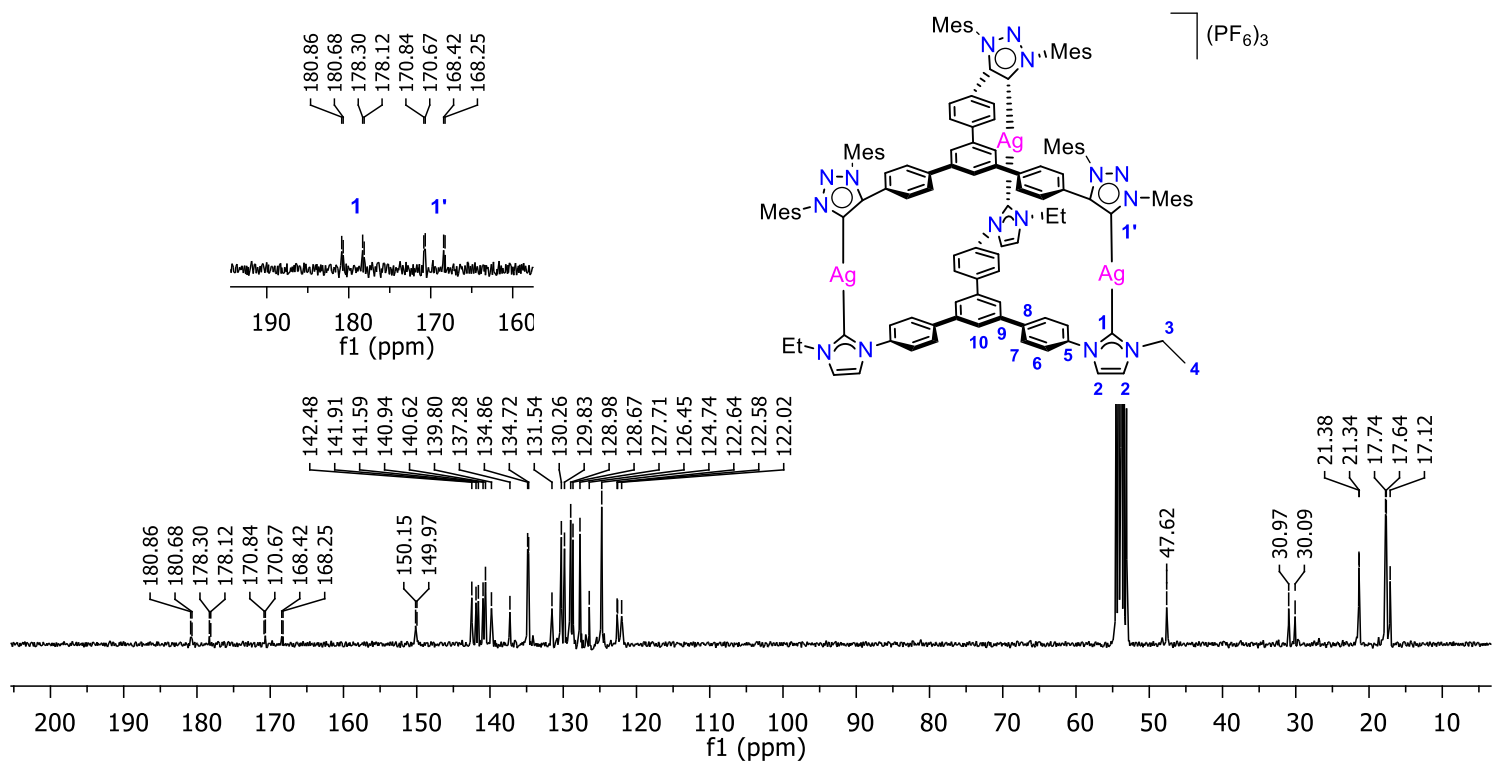

Figure 3.7. ${ }^{13} \mathrm{C}\left\{{ }^{1} \mathrm{H}\right\}$ NMR spectrum of $\left[\mathbf{1 B}^{\mathrm{Et}} \mathbf{C}^{\mathrm{Mes}}\right]\left(\mathbf{P F}_{6}\right)_{3}$ in $\mathrm{CD}_{2} \mathrm{Cl}_{2}$

\subsubsection{Reactivity studies and ligand exchange reactions}

Prompted by these encouraging results, we decided to explore a combinatorial synthetic route for the preparation of $\left[\mathbf{1 B}^{\mathrm{Et}} \mathbf{C}^{\mathrm{Mes}}\right]\left(\mathbf{P F}_{\mathbf{6}}\right)_{3}$. The reactions that we studied were: i) the reorganization of the preformed homo-MIC $\left(\left[\mathbf{5 C}^{\mathbf{M e s}}\right]\left(\mathbf{P F}_{\mathbf{6}}\right)_{3}\right)$ and homo-NHC $\left(\left[\mathbf{5 B}^{\mathrm{Et}}\right]\left(\mathbf{P F}_{\mathbf{6}}\right)_{3}\right)$ cages; ii) the reaction between the cage $\left[\mathbf{5 C}^{\mathrm{Mes}}\right]\left(\mathbf{P F}_{\mathbf{6}}\right)_{3}$ and the salt $\left[\mathbf{H}_{3} \mathbf{B}^{\mathrm{Et}}\right]\left(\mathbf{P F}_{\mathbf{6}}\right)_{3}$, and iii) the reaction between the cage $\left[\mathbf{5 B}^{\mathrm{Et}}\right]\left(\mathbf{P F}_{\mathbf{6}}\right)_{3}$ and the salt $\left[\mathbf{H}_{3} \mathbf{C}^{\mathrm{Mes}}\right]\left(\mathbf{P F}_{6}\right)_{3}$. All reactions were carried out in $\mathrm{MeOH}$ at $60^{\circ} \mathrm{C}$ for $12 \mathrm{~h}$. The schematic representation of these processes is depicted in Scheme 3.4). 


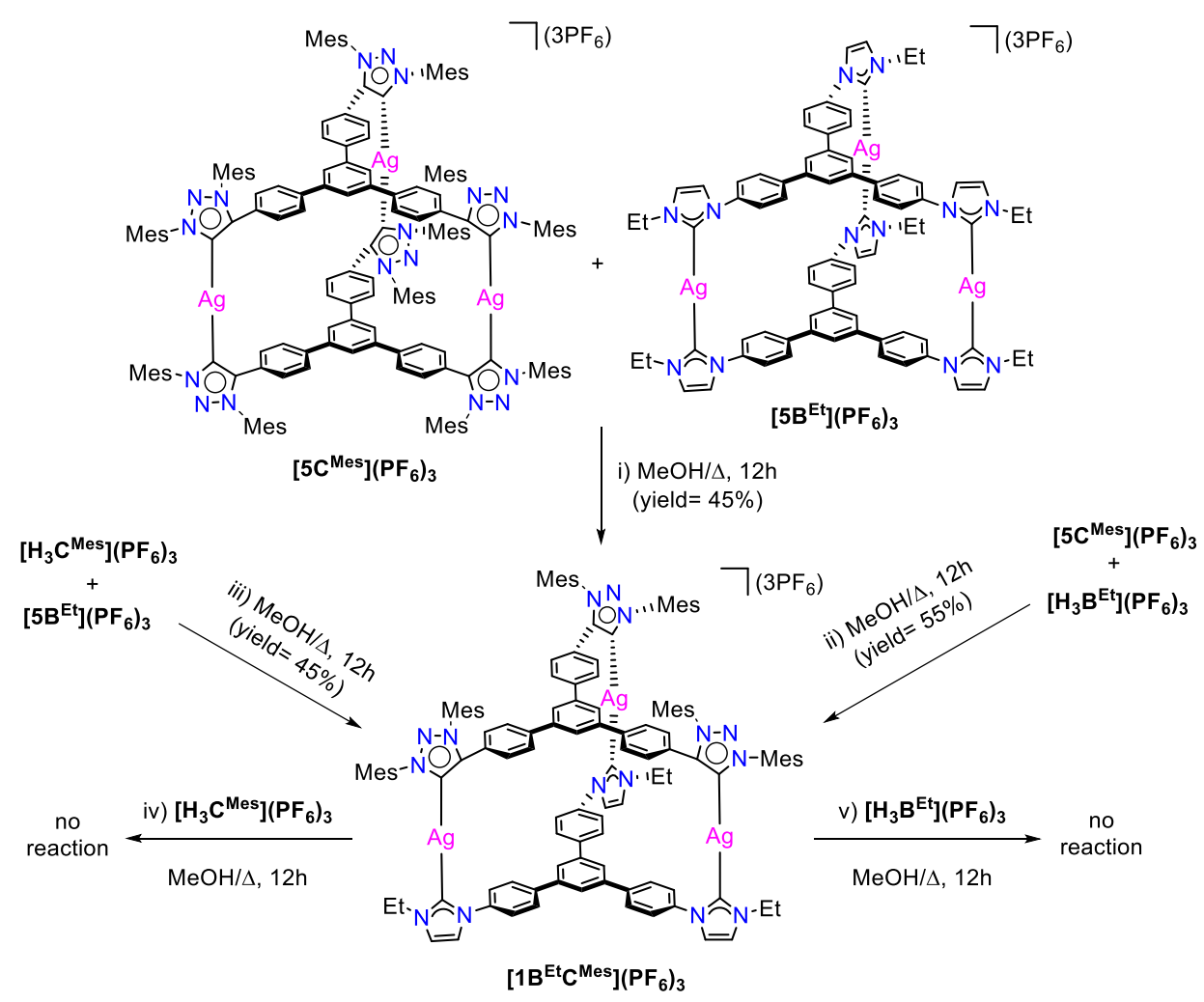

Scheme 3.4. Study of reactivity

The study of the products resulting from each reaction revealed that processes, i), ii) and iii) produced the mixed NHC-MIC cage $\left[\mathbf{1 B}^{\mathrm{Et}} \mathbf{C}^{\mathrm{Mes}}\right]\left(\mathbf{P F}_{\mathbf{6}}\right)_{3}$ in $40-50 \%$ yield, as the only detected (mass spectrometry) and isolable product. Processes iv) and v) (Scheme 3.4), involving the reaction of equimolecular amounts of $\left[\mathbf{1 B}^{\mathbf{E t}} \mathbf{C}^{\mathbf{M e s}}\right]\left(\mathbf{P F}_{\mathbf{6}}\right)_{\mathbf{3}}$ and $\left[\mathbf{H}_{3} \mathbf{C}^{\mathrm{Mes}}\right]\left(\mathbf{P F}_{\mathbf{6}}\right)_{3}$ (iv), and the reaction of equimolecular amounts of $\left[\mathbf{1 B}^{\mathrm{Et}} \mathbf{C}^{\mathrm{Mes}}\right]\left(\mathbf{P F}_{\mathbf{6}}\right)_{\mathbf{3}}$ and $\left[\mathbf{H}_{3} \mathbf{B}^{\mathrm{Et}}\right]\left(\mathbf{P F}_{\mathbf{6}}\right)_{3}(\mathrm{v})$, did not show any reorganization of the carbene ligands, and complex $\left[\mathbf{1 B}^{\mathrm{Et}} \mathbf{C}^{\mathrm{Mes}}\right]\left(\mathbf{P F}_{\mathbf{6}}\right)_{3}$ was quasi-quantitatively recovered from the reaction mixtures.

\section{$\underline{\text { DFT studies }}$}

These results indicate that, regardless of the thermodynamic of the overall reactions, the mixed MIC-NHC complex $\left[\mathbf{1 B}^{\mathrm{Et}} \mathbf{C}^{\mathbf{M e s}}\right]\left(\mathbf{P F}_{\mathbf{6}}\right)_{3}$ can be formed and isolated from reactions involving the combination of the two tris-carbene-based metallocages, or by reaction of each tris-carbene-based metallocages with the related azolium salt, as depicted in Scheme 3.4. The reorganization of the ligand is also kinetically favored, as silver carbenes are often used for carbene transfer processes, ${ }^{[15 b, 25]}$ although in our case, we 
show an unusual example of carbene transfer affording an intermolecular recombination of ligands.

In order to shed some light on these results, and to determine if the formation of the mixed MIC-NHC complex $\left[\mathbf{1 B}^{\mathrm{Et}} \mathbf{C}^{\mathrm{Mes}}\right]\left(\mathbf{P F}_{\mathbf{6}}\right)_{3}$ is thermodynamically favorable compared to $\left[\mathbf{5 C}^{\mathrm{Mes}}\right]\left(\mathbf{P F}_{\mathbf{6}}\right)_{3}$ and $\left[\mathbf{5 B}^{\mathrm{Et}}\right]\left(\mathbf{P F}_{\mathbf{6}}\right)_{3}$, we decided to calculate the thermodynamic parameters of reaction i) shown in Scheme 3.4 by M06L DFT calculations. Since goodquality computational modelling of the complete structures $\left[\mathbf{5 C}^{\mathrm{Mes}}\right]\left(\mathbf{P F}_{\mathbf{6}}\right)_{3},\left[\mathbf{5 B}^{\mathrm{Et}}\right]\left(\mathbf{P F}_{\mathbf{6}}\right)_{3}$, and $\left[\mathbf{1 B}^{\mathrm{Et}} \mathbf{C}^{\mathrm{Mes}}\right]\left(\mathbf{P F}_{\mathbf{6}}\right)_{3}$ is impossible, the calculations were performed on the mononuclear analogues, which optimized geometries are shown in Figure 3.8. These studies were performed by Prof. Dmitri Gusev (Wilfrid Laurier University, Canada).

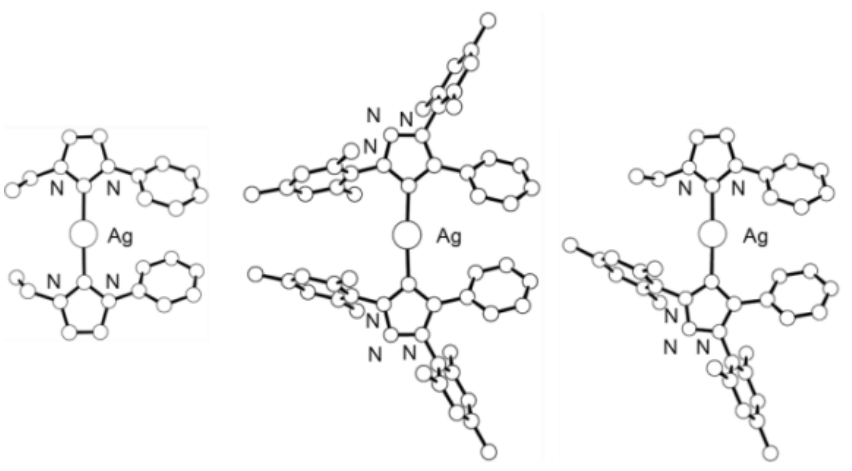

Figure 3.8. Calculated structures of $\left[\mathrm{Ag}(\mathrm{NHC})_{2}\right]^{+},\left[\mathrm{Ag}(\mathrm{MIC})_{2}\right]^{+}$, and $[\mathrm{Ag}(\mathrm{MIC})(\mathrm{NHC})]^{+}$complexes (all hydrogen atoms are omitted for clarity).

In methanol, the formation of the mixed carbene complex, $\left[\mathrm{Ag}(\mathrm{NHC})_{2}\right]^{+}+\left[\mathrm{Ag}(\mathrm{MIC})_{2}\right]^{+}$ $\rightarrow 2[\mathrm{Ag}(\mathrm{NHC})(\mathrm{MIC})]^{+}$, is thermo-neutral: $\Delta \mathrm{H}=0.0 \mathrm{kcal} / \mathrm{mol}$, whereas in the benzene (less polar) this reaction is slightly favorable: $\Delta \mathrm{H}=-1.6 \mathrm{kcal} / \mathrm{mol}$. The calculated Ag-C bond enthalpy is stronger for the MIC-Ag bond than for the NHC-Ag one in $[\mathrm{Ag}(\mathrm{NHC})(\mathrm{MIC})]^{+}(44.0$ vs. $41.8 \mathrm{kcal} / \mathrm{mol}$ in methanol). 


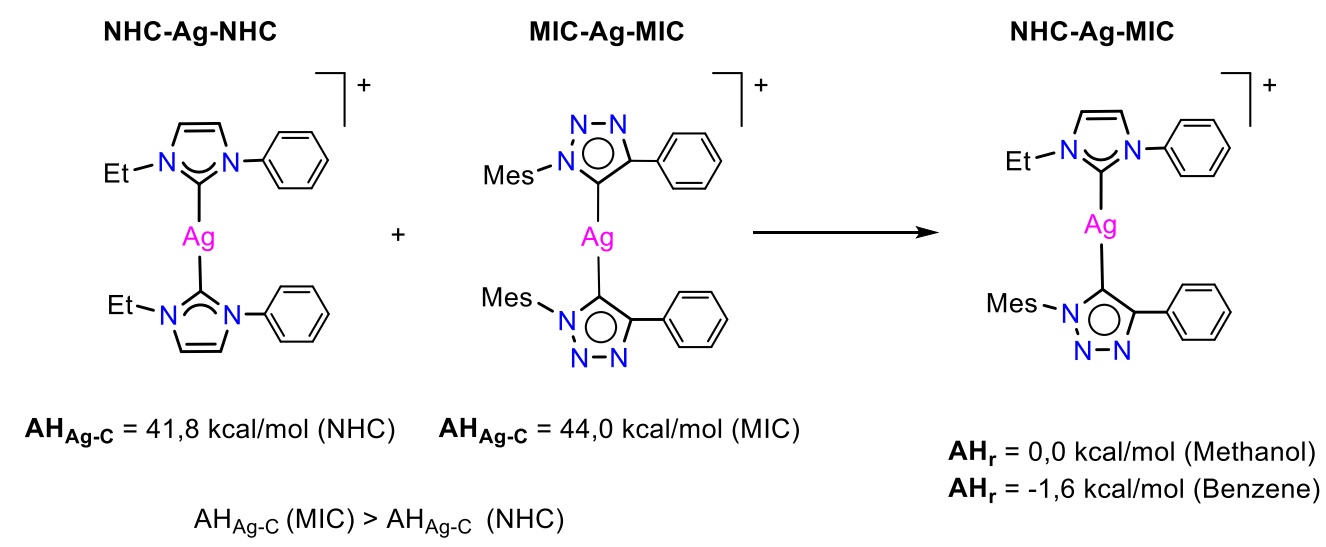

Scheme 3.5. Standard enthalpy of the formation of a NHC-Ag-MIC complex

Based on the computed energies, the mixed carbene complex is predicted to be the main species under equilibrium conditions, and the reasons to be the only isolated complex should be attributed to factors beyond those that we should take into account by DFT studies (solubility of the complex, interactions of $\left[\mathbf{5 C}^{\mathrm{Mes}}\right]\left(\mathbf{P F}_{\mathbf{6}}\right)_{3},\left[\mathbf{5 B}^{\mathrm{Et}}\right]\left(\mathbf{P F}_{\mathbf{6}}\right)_{3}$, and $\left[\mathbf{1 B}^{\mathrm{Et}} \mathbf{C}^{\mathrm{Mes}}\right]\left(\mathbf{P F}_{\mathbf{6}}\right)_{3}$ with the counter-ions $\left[\mathrm{PF}_{6}\right]^{-}$, or explicit interactions with the solvent).

\subsection{Conclusions}

In this Chapter we described the synthesis of a new family of nanometer-sized cylinderlike trinuclear cages based on coinage metals using tris-NHC and tris-MIC ligands. The homoleptic $\mathrm{Ag}^{(\mathrm{I})}$-cages $\left(\left[\mathbf{5 B}^{\mathrm{Et}}\right]\left(\mathbf{P F}_{\mathbf{6}}\right)_{\mathbf{3}}\right.$ and $\left.\left[\mathbf{5 C}^{\mathrm{Mes}}\right]\left(\mathbf{P F}_{\mathbf{6}}\right)_{\mathbf{3}}\right)$ can be readily prepared via metal-controlled self-assembly. The trinuclear silver complex $\left[\mathbf{5 B}^{\mathrm{Et}}\right]\left(\mathbf{P F}_{\mathbf{6}}\right)_{3}$ undergoes transmetallation with $\left[\mathrm{AuCl}\left(\mathrm{SMe}_{2}\right)\right]$ or $\mathrm{CuI}$ to form the corresponding homotrinuclear hexacarbene complexes $\left[\mathbf{6 B}^{\mathrm{Et}}\right]\left(\mathbf{P F}_{6}\right)_{3}, \quad\left[\mathbf{7 B}^{\mathrm{Et}}\right]\left(\mathbf{P F}_{6}\right)_{3}$ respectively. Parallel to this, trinuclear gold complex $\left[\mathbf{6 C}^{\mathrm{Mes}}\right]\left(\mathbf{P F}_{\mathbf{6}}\right)_{3}$ was also obtained via transmetallation by reacting $\left[\mathbf{5 C}^{\mathrm{Mes}}\right]\left(\mathbf{P F}_{\mathbf{6}}\right)_{3}$ with $\left[\mathrm{AuCl}\left(\mathrm{SMe}_{2}\right)\right]$. In all cases, the cylinder-like architecture was maintained. Two of these cages have been characterised by X-ray diffraction. The new structures show a large cavity volume, and may be related to previous cylinder-like hexa-NHC structures developed by our group. ${ }^{[13 f]}$ The presence of the cavity suggests that further studies may be needed for the utilization of these species for the encapsulation of aromatic guests.

Finally, we were able to synthesize a unique heteroleptic NHC-MIC cylinder-shaped cage $\left(\left[\mathbf{1 B}^{\mathrm{Et}} \mathbf{C}^{\mathrm{Mes}}\right]\left(\mathbf{P F}_{\mathbf{6}}\right)_{3}\right)$, by the recombination of the ligands in the related MIC- and NHC-based cylinders, and by several other combinations. This reaction involves an 
unusual rearrangement, which clearly illustrates the liability of the tris-NHC and trisMIC ligands on silver in solution, paving the way for new applications such as guest release, or latent catalysis. 


\subsection{References}

[1] J. M. Lehn, A. Rigault, J. Siegel, J. Harrowfield, B. Chevrier and D. Moras, Proc. Natl. Acad. Sci. U. S. A. 1987, 84, 2565-2569.

[2] E. C. Constable, Chem. Ind. 1994, 56-59.

[3] a) M. Fujita, Chem. Soc. Rev. 1998, 27, 417-425; b) M. Fujita, M. Tominaga, A. Hori and B. Therrien, Acc. Chem. Res. 2005, 38, 369-378.

[4] D. L. Caulder and K. N. Raymond, Acc. Chem. Res. 1999, 32, 975-982.

[5] a) P. J. Stang and B. Olenyuk, Acc. Chem. Res. 1997, 30, 502-518; b) S. Leininger, B. Olenyuk and P. J. Stang, Chem. Rev. 2000, 100, 853-907; c) R. Chakrabarty, P. S. Mukherjee and P. J. Stang, Chem. Rev. 2011, 111, 6810-6918; d) T. R. Cook, Y.-R. Zheng and P. J. Stang, Chem. Rev. 2013, 113, 734-777.

[6] a) J. R. Nitschke, Acc. Chem. Res. 2007, 40, 103-112; b) M. M. J. Smulders, I. A. Riddell, C. Browne and J. R. Nitschke, Chem. Soc. Rev. 2013, 42, 1728-1754; c) A. M. Castilla, W. J. Ramsay and J. R. Nitschke, Acc. Chem. Res. 2014, 47, 2063 2073; d) S. Zarra, D. M. Wood, D. A. Roberts and J. R. Nitschke, Chem. Soc. Rev. 2015, 44, 419-432.

[7] a) E. C. Constable, Chem. Soc. Rev. 2007, 36, 246-253; b) E. C. Constable, Coord. Chem. Rev. 2008, 252, 842-855; c) E. C. Constable, Chem. Soc. Rev. 2013, 42, 1637-1651.

[8] a) P. J. Steel and C. M. Fitchett, Coord. Chem. Rev. 2008, 252, 990-1006; b) M. D. Ward, Chem. Commun. 2009, 4487-4499; c) P. Dydio and J. N. H. Reek, Chem. Sci. 2014, 5, 2135-2145.

[9] a) M. D. Pluth and K. N. Raymond, Chem. Soc. Rev. 2007, 36, 161-171; b) B. Birkmann, A. W. Ehlers, R. Frohlich, K. Lammertsma and F. E. Hahn, Chem. Eur. J. 2009, 15, 4301-4311; c) Y.-F. Han, W.-G. Jia, Y.-J. Lin and G.-X. Jin, Angew. Chem. Int. Ed. 2009, 48, 6234-6238; d) P. Mal, B. Breiner, K. Rissanen and J. R. Nitschke, Science 2009, 324, 1697-1699; e) J. W. Leeland, F. J. White and J. B. Love, J. Am. Chem. Soc. 2011, 133, 7320-7323; f) P. D. Frischmann and M. J. MacLachlan, Chem. Soc. Rev. 2013, 42, 871-890.

[10] a) F. Wurthner, C. C. You and C. R. Saha-Moller, Chem. Soc. Rev. 2004, 33, $133-$ 146; b) P. J. Steel, Acc. Chem. Res. 2005, 38, 243-250.

[11] a) J. A. Mata, M. Poyatos and E. Peris, Coord. Chem. Rev. 2007, 251, 841-859; b) M. Poyatos, J. A. Mata and E. Peris, Chem. Rev. 2009, 109, 3677-3707. 
[12] a) M. Viciano, M. Sanau and E. Peris, Organometallics 2007, 26, 6050-6054; b) F. E. Hahn, C. Radloff, T. Pape and A. Hepp, Organometallics 2008, 27, 64086410; c) C. Radloff, F. E. Hahn, T. Pape and R. Fröhlich, Dalton Trans. 2009, 7215-7222; d) C. Radloff, J. J. Weigand and F. E. Hahn, Dalton Trans. 2009, 9392-9394; e) F. M. Conrady, R. Fröhlich, C. Schulte to Brinke, T. Pape and F. E. Hahn, J. Am. Chem. Soc. 2011, 133, 11496-11499; f) M. Schmidtendorf, T. Pape and F. E. Hahn, Angew. Chem. Int. Ed. 2012, 51, 2195-2198.

[13] a) F. E. Hahn, C. Radloff, T. Pape and A. Hepp, Chem. Eur. J. 2008, 14, 1090010904; b) C. Radloff, H. Y. Gong, C. Schulte to Brinke, T. Pape, V. M. Lynch, J. L. Sessler and F. E. Hahn, Chem. Eur. J. 2010, 16, 13077-13081; c) A. Rit, T. Pape and F. E. Hahn, J. Am. Chem. Soc. 2010, 132, 4572-4573; d) D. H. Wang, B. G. Zhang, C. He, P. Y. Wu and C. Y. Duan, Chem. Commun. 2010, 46, 47284730; e) A. Rit, T. Pape, A. Hepp and F. E. Hahn, Organometallics 2011, 30, 334347; f) C. Segarra, G. Guisado-Barrios, F. E. Hahn and E. Peris, Organometallics 2014, 33, 5077-5080; g) N. Sinha, F. Roelfes, A. Hepp, C. Mejuto, E. Peris and F. E. Hahn, Organometallics 2014, 33, 6898-6904.

[14] a) O. Guerret, S. Sole, H. Gornitzka, M. Teichert, G. Trinquier and G. Bertrand, J. Am. Chem. Soc. 1997, 119, 6668-6669; b) A. J. Boydston and C. W. Bielawski, Dalton Trans. 2006, 4073-4077; c) L. Mercs, A. Neels and M. Albrecht, Dalton Trans. 2008, 5570-5576; d) B. Karimi and P. F. Akhavan, Chem. Commun. 2009, 3750-3752; e) L. Mercs, A. Neels, H. Stoeckli-Evans and M. Albrecht, Dalton Trans. 2009, 7168-7178; f) J. Choi, H. Y. Yang, H. J. Kim and S. U. Son, Angew. Chem. Int. Ed. 2010, 49, 7718-7722; g) B. Karimi and P. F. Akhavan, Chem. Commun. 2011, 47, 7686-7688; h) B. Karimi and P. F. Akhavan, Inorg. Chem. 2011, 50, 6063-6072; i) C. Zhang, J. J. Wang, Y. Liu, H. Ma, X. L. Yang and H. B. Xu, Chem. Eur. J. 2013, 19, 5004-5008; j) S. Gonell, M. Poyatos and E. Peris, Chem. Eur. J. 2014, 20, 5746-5751.

[15] a) J. C. Garrison and W. J. Youngs, Chem. Rev. 2005, 105, 3978-4008; b) I. J. B. Lin and C. S. Vasam, Coord. Chem. Rev. 2007, 251, 642-670; c) J. C. Y. Lin, R. T. W. Huang, C. S. Lee, A. Bhattacharyya, W. S. Hwang and I. J. B. Lin, Chem. Rev. 2009, 109, 3561-3598.

[16] E. Peris, Chem. Commun. 2016, 52, 5777-5787.

[17] a) G. Guisado-Barrios, J. Bouffard, B. Donnadieu and G. Bertrand, Organometallics 2011, 30, 6017-6021; b) D. I. Bezuidenhout, G. Kleinhans, G. 
Guisado-Barrios, D. C. Liles, G. Ung and G. Bertrand, Chem. Commun. 2014, 50, 2431-2433.

[18] a) W. W. H. Wong, M. S. Vickers, A. R. Cowley, R. L. Paul and P. D. Beer, Organic \& Biomolecular Chemistry 2005, 3, 4201-4208; b) J. Yoon, S. K. Kim, N. J. Singh and K. S. Kim, Chem. Soc. Rev. 2006, 35, 355-360; c) M. Yoshizawa, M. Tamura and M. Fujita, Science 2006, 312, 251-254; d) M. D. Pluth, R. G. Bergman and K. N. Raymond, Science 2007, 316, 85-88; e) B. Birkmann, R. Froehlich and F. E. Hahn, Chem. Eur. J. 2009, 15, 9325-9329.

[19] a) C. Mejuto, G. Guisado-Barrios and E. Peris, Organometallics 2014, 33, 32053211; b) C. Mejuto, G. Guisado-Barrios, D. Gusev and E. Peris, Chem. Commun. 2015, 51, 13914-13917; c) C. Mejuto, B. Royo, G. Guisado-Barrios and E. Peris, Beilstein J. Org. Chem. 2015, 11, 2584-2590.

[20] a) Q.-X. Liu, Z.-Q. Yao, X.-J. Zhao, A.-H. Chen, X.-Q. Yang, S.-W. Liu and X.G. Wang, Organometallics 2011, 30, 3732-3739; b) J. Cure, R. Poteau, I. C. Gerber, H. Gornitzka and C. Hemmert, Organometallics 2012, 31, 619-626.

[21] a) G. Guisado-Barrios, J. Bouffard, B. Donnadieu and G. Bertrand, Angew. Chem. Int. Ed. 2010, 49, 4759-4762; b) R. H. Crabtree, Coord. Chem. Rev. 2013, 257, 755-766; c) K. F. Donnelly, A. Petronilho and M. Albrecht, Chem. Commun. 2013, 49, 1145-1159.

[22] P. Mathew, A. Neels and M. Albrecht, J. Am. Chem. Soc. 2008, 130, 1353413535.

[23] a) J. Cai, X. Yang, K. Arumugam, C. W. Bielawski and J. L. Sessler, Organometallics 2011, 30, 5033-5037; b) M. T. Zamora, M. J. Ferguson and M. Cowie, Organometallics 2012, 31, 5384-5395; c) E. C. Keske, O. V. Zenkina, R. Wang and C. M. Crudden, Organometallics 2012, 31, 456-461; d) E. C. Keske, O. V. Zenkina, R. Wang and C. M. Crudden, Organometallics 2012, 31, 6215-6221; e) R. Maity, S. Hohloch, C.-Y. Su, M. van der Meer and B. Sarkar, Chem. Eur. J. 2014, 20, 9952-9961; f) R. Maity, M. van der Meer and B. Sarkar, Dalton Trans. 2015, 44, 46-49; g) S. Hohloch, S. Kaiser, F. L. Duecker, A. Bolje, R. Maity, J. Kosmrlj and B. Sarkar, Dalton Trans. 2015, 44, 686-693; h) R. Maity, M. Van der Meer, S. Hohloch and A. Sarkar, Organometallics 2015, 34, 3090-3096.

[24] a) D. Canseco-Gonzalez, A. Petronilho, H. Mueller-Bunz, K. Ohmatsu, T. Ooi and M. Albrecht, J. Am. Chem. Soc. 2013, 135, 13193-13203; b) F. Lazreg, D. B. Cordes, A. M. Z. Slawin and C. S. J. Cazin, Organometallics 2015, 34, 419-425. 
[25] a) I. J. B. Lin and C. S. Vasam, Comments Inorg. Chem. 2004, 25, 75-129; b) C. E. Strasser, E. Stander-Grobler, O. Schuster, S. Cronje and H. G. Raubenheimer, Eur. J. Inorg. Chem. 2009, 1905-1912. 



\title{
Chapter 4
}

\author{
A Corannulene-Bridged Bis-N- \\ Heterocyclic Carbene: Synthesis, \\ Coordination and Supramolecular \\ Properties
}





\subsection{Introduction}

During the last few years, a great effort has been devoted to the preparation of di- and tris-N-heterocyclic carbene ligands connected by polyaromatic linkers, because they were thought to be beneficial for the development of improved materials with applications in homogeneous catalysts and materials chemistry. ${ }^{[1]}$ In this context, our group actively contributed to the field by developing a series of rigid di- and tris-Nheterocyclic carbene ligands (Chart 4.1). ${ }^{[2]}$
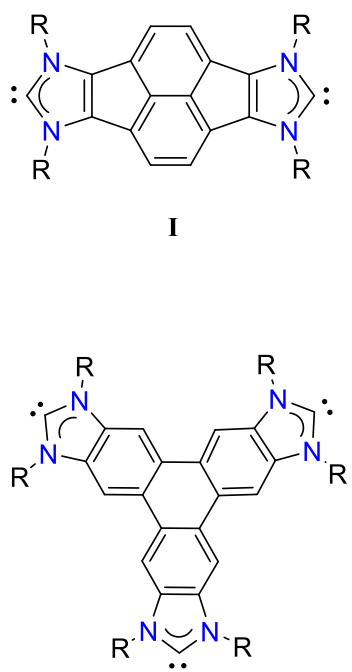

IV

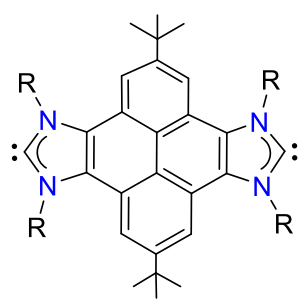

II

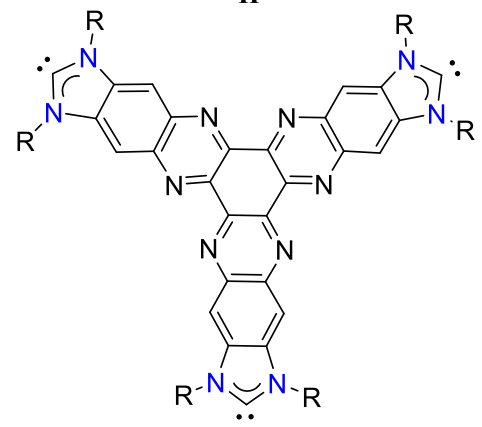

$\mathbf{V}$

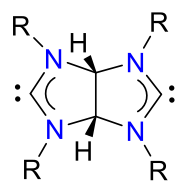

III

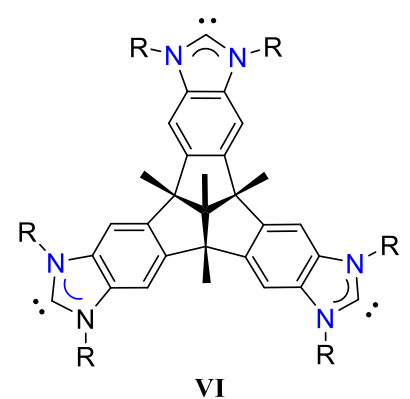

VI

Chart 4.1. Examples of di- (I, II, III) and tris-N-heterocyclic (IV, V, VI) carbene ligands

In a continuation of this research, we turned our attention to corannulene as an alternative to the known planar polyaromatic linkers used in the design of previous rigid bis-NHC ligands. Corannulene is a bowl-shaped polyaromatic hydrocarbon with unique electronic and topologic features. ${ }^{[3]}$ We thought that a corannulene derivative bearing bis-NHC moieties in its periphery could be applied not only in catalysis but also in supramolecular binding studies with fullerenes.

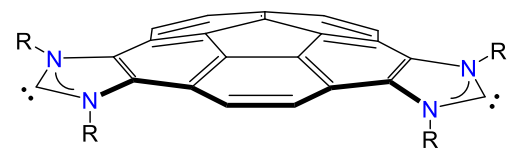

Chart 4.2. Corannulene-based NHC ligand 
Shape complementary is probably the most important factor to consider in the design of supramolecular-based receptors. Since the discovery of fullerenes, the interaction of their curved conjugated surfaces with properly assembled polyaromatic systems has been an area of intense research. ${ }^{[4]}$ The main target of this research is to find effective receptors that provide selective association of specific fullerenes to facilitate their separation from complex mixtures. ${ }^{[5]}$ Bowl-shaped polyaromatic hydrocarbons, such as corannulene, which can now be prepared on the $\mathrm{kg}$ scale, ${ }^{[6]}$ have demonstrated to be among the best candidates to build fullerene receptors, due to the complementarity of their concave and convex surfaces. ${ }^{[3 \mathrm{c}]}$ However, although it has been computationally demonstrated that the complexation of corannulene to $\mathrm{C}_{60}$ should be energetically favorable in the gas phase, ${ }^{[7]}$ and it has also been detected in the solid state, ${ }^{[8]}$ no evidence of significant binding affinity of the two has been reported in solution. Some sophisticated receptors combining several tethered corannulene subunits, so-called 'buckycatchers', showed affinity for the formation of host-guest complexes with fullerenes in solution (some representative examples are VII-IX, shown in Chart 4.3). ${ }^{[9]}$
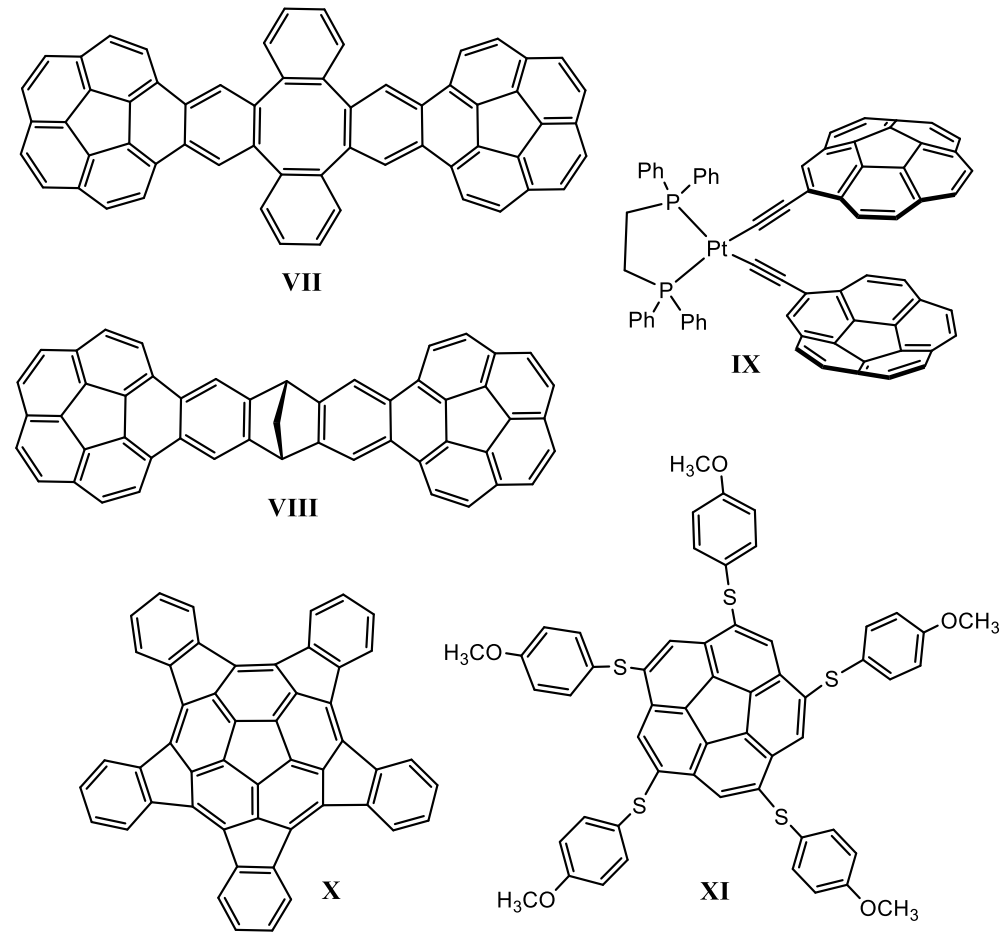

Chart 4.3. Examples of compounds based on the corannulene core 
On the other hand, pentaindenocorannulene $(\mathbf{X})$ displays a cap curvature similar to corannulene, but the presence of the five benzofingers creates a larger surface area and also a larger bowl depth. ${ }^{[7 d, 10]}$ In this context, a recent study described the formation of assemblies of pentaindenocorannulene with $\mathrm{C}_{60}$ in solution and in the solid state, ${ }^{[11]}$ thus evidencing that this extended form of corannulene is a better receptor for recognizing fullerenes. Similarly, corannulene derivatives with geodesic electron-rich arms (XI) were found to form 1:1 complexes with $\mathrm{C}_{60}$ in toluene solution, with association constants ranging from 200 to $400 \mathrm{M}^{-1} \cdot{ }^{[12]}$ This finding was interpreted as a consequence of the enhanced attractive noncovalent interaction between the electronically complementary surfaces of the functionalized corannulene and $\mathrm{C}_{60}$, due to the introduction of the electronrich arms.

This Chapter describes the synthesis of a set of corannulene-adorned bis-imidazolium salts, along with their coordination to $\mathrm{Rh}^{(\mathrm{I})}$ and $\mathrm{Au}^{(\mathrm{I})}$. The Chapter will also include molecular recognition studies focused on the interaction between a bowl-shaped gold complex and $\mathrm{C}_{60}$-fullerene, by means of host-guest supramolecular techniques based on ${ }^{1} \mathrm{H}$ NMR spectroscopy, fluorescence spectroscopy, calorimetric studies and computational calculations.

The work described in this Chapter is the result of the collaboration with three different research groups. The starting material (1,2,5,6-tetrabromocorannulene), was provided by the group of Prof. Jay S. Siegel (Tianjin University, China). The group of Prof. Pau Ballester (Institut Català d'Investigació Química-ICIQ, Tarragona) performed the ITC (Isothermal Titration Calorimetry) measurements and provided guidance in the interpretation of the results derived from the supramolecular studies. Finally, Prof. Dmitri Gusev (Wilfrid Laurier University, Canada) carried out the computational studies, and provided key data for the interpretation of the results.

\subsection{Results and discussion}

\subsubsection{Synthesis and characterization of corannulene-linked bis- imidazolium salts}

The synthetic procedures employed for the preparation of the two bis-imidazolium salts with a corannulene linker are depicted in Scheme 4.1. First, tetrabromocorannulene $\mathbf{E}^{[6]}$ is tetra-aminated with tert-butylamine via a palladium-catalyzed Buchwald-Hartwig amination $^{[2 f, 13]}$ [the palladium catalyst is generated in situ from the reaction between 
$\mathrm{Pd}(\mathrm{OAc})_{2}$ and $\mathrm{IPr} H \mathrm{HCl}$ (1,3-bis(2,6-diisopropylphenyl)imidazolium chloride) in the presence of $\mathrm{NaO} t \mathrm{Bu}]$. The reaction generates the tetraamino-corannulene $\mathbf{F}$ in almost quantitative yield (97\%). The bis-annulation of $\mathbf{F}$ in neat tri- $n$-butyl orthoformate in the presence of ammonium hexafluorophosphate generates the bis-imidazolium salts $\left[\mathrm{H}_{2} \mathbf{G}^{t \mathrm{Bu}^{3}}\right]\left(\mathbf{P F}_{6}\right)_{2}$ or $\left[\mathbf{H}_{2} \mathbf{G}^{n \mathrm{Bu}}\right]\left(\mathbf{P F}_{6}\right)_{2}$, depending on the reaction conditions used. The bisazolium salt $\left[\mathbf{H}_{\mathbf{2}} \mathbf{G}^{\boldsymbol{t} \mathbf{B u}}\right]\left(\mathbf{P F}_{\mathbf{6}}\right)_{\mathbf{2}}$ (bearing tert-butyl N-substituents) was obtained when the reaction was carried out at room temperature during several days. In contrast, when the reaction mixture was heated at $150{ }^{\circ} \mathrm{C}$ overnight, the bis-azolium salt $\left[\mathbf{H}_{\mathbf{2}} \mathbf{G}^{n \mathbf{B u}}\right]\left(\mathbf{P F}_{\mathbf{6}}\right)_{2}$ (with $n$-butyl wingtips) was the major product obtained. The replacement of the tertbutyl group by the $n$-butyl in the cyclization of tert-butyl substituted bis-ammino compounds using tri- $n$-butyl orthoformate, was previously observed for the preparation of several bis-azolium salts in our group, ${ }^{[2 \mathrm{~d}, \mathrm{f}]}$ and it was justified as being a consequence of the steric constraints imposed during the rehybridation of the nitrogen atoms from $s p^{3}$ to $s p^{2}$.

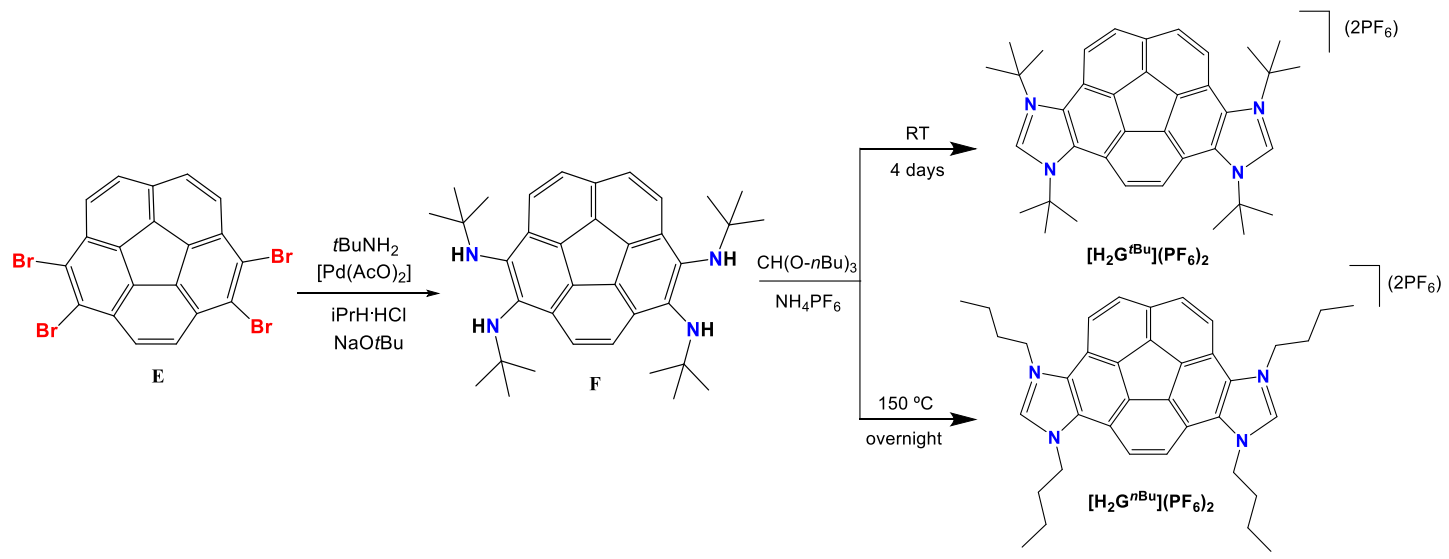

Scheme 4.1. Synthetic routes to bis-imidazolium salts $\left.\left[\mathbf{H}_{2} \mathbf{G}^{n \mathrm{Bu}}\right]\left(\mathbf{P F}_{6}\right)_{2}\right)$ and $\left(\left[\mathrm{H}_{2} \mathbf{G}^{\mathrm{tBu}}\right]\left(\mathbf{P F}_{6}\right)_{2}\right.$

Compounds $\mathbf{F},\left[\mathbf{H}_{2} \mathbf{G}^{n \mathrm{Bu}}\right]\left(\mathbf{P F}_{6}\right)_{2}$ and $\left[\mathbf{H}_{2} \mathbf{G}^{t \mathrm{Bu}}\right]\left(\mathbf{P F}_{6}\right)_{2}$ were characterized by means of NMR spectroscopy, Mass Spectrometry and Elemental Analysis. A common feature of their NMR spectra is that they are consistent with their predicted Cs-symmetry. As an illustrative example, the ${ }^{1} \mathrm{H}$ NMR spectrum of $\left[\mathbf{H}_{\mathbf{2}} \mathbf{G}^{\mathbf{t} \mathbf{B u}}\right]\left(\mathbf{P F}_{\mathbf{6}}\right)_{2}$ is described below. All details regarding the synthesis and spectroscopic features of compounds $\mathbf{F}$, $\left[\mathbf{H}_{2} \mathbf{G}^{n \mathbf{B u}}\right]\left(\mathbf{P F}_{6}\right)_{2}$ can be found in the Experimental Section (Chapter 5). 


\section{${ }^{1} H$ NMR spectrum of $\left[\boldsymbol{H}_{2} \boldsymbol{G}^{\mathbf{B u}}\right]\left(\boldsymbol{P F}_{\mathbf{6}}\right)_{2}$}

Figure 4.1 shows the ${ }^{1} \mathrm{H}$ NMR spectrum of $\left[\mathbf{H}_{\mathbf{2}} \mathbf{G}^{t \mathbf{B u}}\right]\left(\mathbf{P F}_{\mathbf{6}}\right)_{2}$. The singlet due to the acidic protons of the $\mathrm{NCHN}$ fragments (e) is displayed at $9.55 \mathrm{ppm}$. The signals assigned to the protons of the corannulene core $(\mathbf{a}, \mathbf{b}$ and $\mathbf{c})$ are displayed at 9.13(s), 8.90(d) and 8.54(d) ppm, respectively. Finally, the signal due to the protons of the tert-butyl groups appears at $2.32 \mathrm{ppm}(\mathbf{d})$.
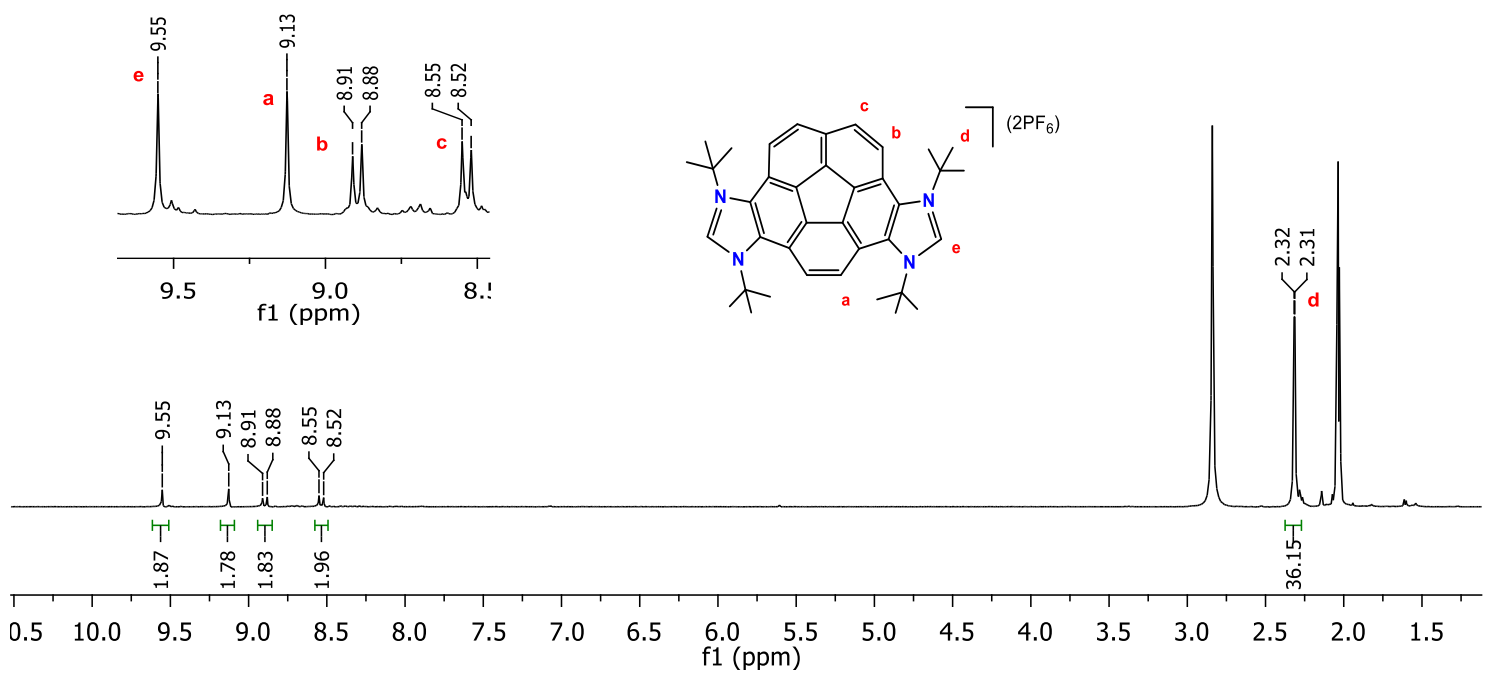

Figure 4.1. ${ }^{1} \mathrm{H}$ NMR spectrum of $\left[\mathbf{H}_{2} \mathbf{G}^{\prime \mathbf{B u}}\right]\left(\mathbf{P F}_{6}\right)_{2}$ in $\left(\mathrm{CD}_{3}\right)_{2} \mathrm{CO}$

\section{Molecular structure of $\left[\mathbf{H}_{2} \boldsymbol{G}^{\boldsymbol{B} \boldsymbol{B u}}\right]\left(\mathbf{P F}_{6}\right)_{2}$}

The molecular structure of $\left[\mathbf{H}_{2} \mathbf{G}^{\mathbf{t} \mathbf{B u}}\right]\left(\mathbf{P F}_{\mathbf{6}}\right)_{2}$ was unequivocally confirmed by single crystal X-ray diffraction (Figure 4.2). The structure reveals the presence of the two imidazolium rings bridged by the corannulene linker.

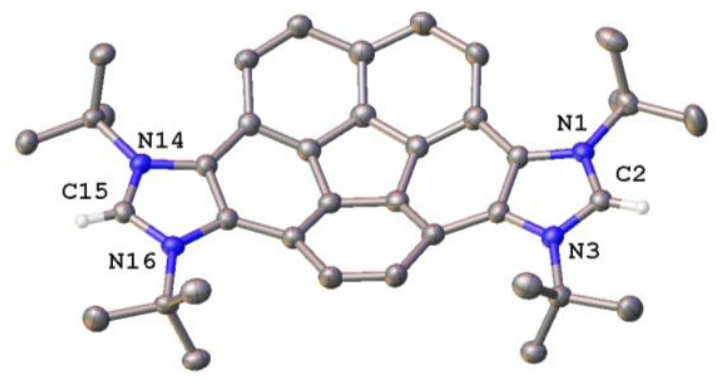

Figure 4.2. Molecular structure of $\left[\mathbf{H}_{2} \mathbf{G}^{\mathbf{t B u}}\right]\left(\mathbf{P F}_{6}\right)_{2}$. Hydrogen atoms (except those hydrogen atoms bond to $\mathrm{C} 2$ and $\mathrm{C} 15$ )and conterions have been omitted for clarity. Ellipsoids at $50 \%$ of probability 
The bowl-shape conformation of the corannulene unit induces a dihedral angle between the planes of the two azoles of $169.4^{\circ}$ (Figure 4.3), thus making the two imidazolium fragments no co-planar.

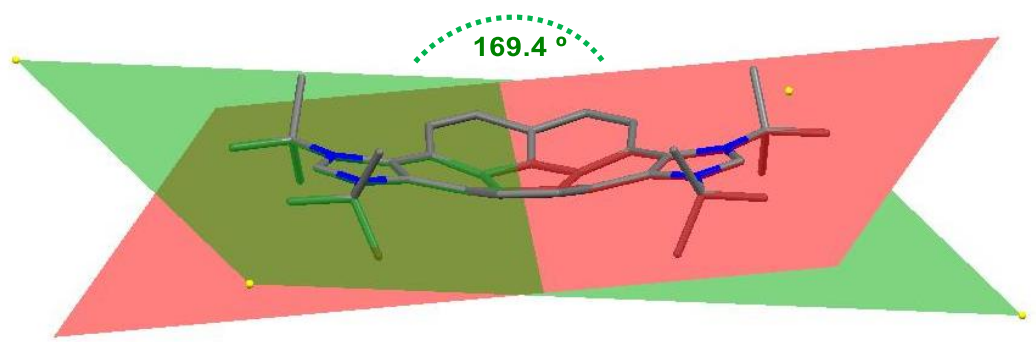

Figure 4.3. Dihedral angle between the planes of the two azoles of $\left[\mathbf{H}_{2} \mathbf{G}^{\mathrm{tBu}}\right]\left(\mathbf{P F}_{\mathbf{6}}\right)_{2}$

The tert-butyl substituents of the nitrogen atoms adopt the less hindered conformation by pointing one of the methyl groups toward the coordination plane of a potential metal fragment, assuming that a N-heterocyclic carbene complex could eventually be formed. Based on the X-ray structure of $\left[\mathbf{H}_{2} \mathbf{G}^{\mathbf{B u}}\right]\left(\mathbf{P F}_{6}\right)_{2}$, the potential metal-to-metal distance for a putative dimetallic complex bound to this di-NHC precursor would approximately be of $11.9 \AA$.

The steric hindrance of the potential bis-NHC ligand generated from the deprotonation of $\left[\mathbf{H}_{2} \mathbf{G}^{t \mathbf{B u}}\right]\left(\mathbf{P F}_{\mathbf{6}}\right)_{2}$, was estimated by calculating the percent of buried volume ( $\left.\% V_{\mathrm{Bur}}\right)$. The $\% V_{\text {Bur }}$ is defined as the percentage of the total volume of a sphere centred in the metal, which is occupied by the reference ligand. ${ }^{[14]}$ This parameter, first introduced by Nolan and Cavallo, and now is commonly employed for measuring the steric bulk of NHC ligands. ${ }^{[15]}$ Based on the molecular structure of $\left[\mathbf{H}_{\mathbf{2}} \mathbf{G}^{\mathbf{t} \mathbf{B u}}\right]\left(\mathbf{P} \mathbf{F}_{\mathbf{6}}\right)_{2}$, the percent of steric bulk assigned to the putative di-NHC ligand was calculated by using the Samb $V$ ca free software developed by Cavallo and co-workers ${ }^{[16]}$ resulting on a $45.1 \%$ (assuming a M-C distance of $2 \AA){ }^{[16]}$

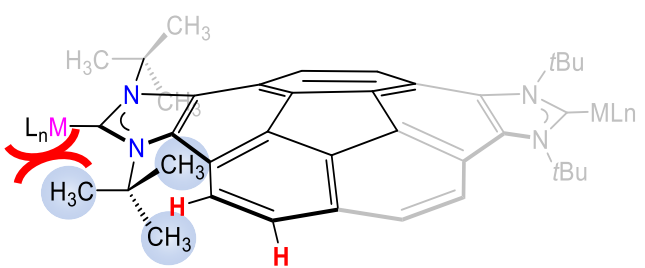

Maximum steric constrain $\% \mathrm{~V}=45.1$

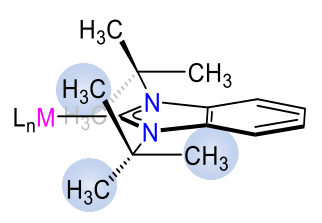

$\% \mathrm{~V}=36.1$

Scheme 4.2. Schematic representation of buried volumes ( $\% V_{\text {Bur }}$ ) 
This value is significantly larger than the steric bulk exhibited by other related $t \mathrm{Bu}-$ substituted NHC ligands (see Scheme 4.2). ${ }^{[14,17]}$ The larger steric bulk observed for our corannulene-based bis-NHC ${ }^{[2 \mathrm{~d}]}$ may be explained by the spatial orientation exhibited by the $t \mathrm{Bu}$-wingtips, where one of methyl groups is enforced towards the coordination sphere of a putative metal, therefore affording a higher steric hindrance than other benzimidazolylidene ligands in which the orientation of the $t \mathrm{Bu}$ groups may allow a less hindered situation.

\subsubsection{Isolation of a corannulene-based bis-NHCs}

The availability of free and stable carbenes (persistent carbenes) can give access to the preparation of metal complexes which cannot be prepared otherwise. ${ }^{[18]}$ In addition, stable carbenes and related metal-free species can activate small molecules and stabilize highly reactive intermediates. ${ }^{[19]}$ Traditionally, carbenes were considered as curiosities and were only studied indirectly, e.g. by trapping reactions. This situation has changed dramatically with the emergence of persistent carbenes. Although they are very reactive molecules (i.e. they can dimerize) many of them can be isolated as pure substances, ${ }^{[20]}$ specially if bulky substituents are incorporated avoiding potential dimerization reactions.

Deprotonation of the bis-imidazolium salt $\left[\mathbf{H}_{2} \mathbf{G}^{t \mathbf{B u}}\right]\left(\mathbf{P F}_{6}\right)_{2}$ was carried out in $\mathrm{C}_{6} \mathrm{D}_{6}$ using sodium bis(trimethylsilyl)amide (NaHMDS, $1 \mathrm{M}$ in THF) and a catalytic amount of $\mathrm{NaO}^{t} \mathrm{Bu}$, as shown in Scheme 4.2. The resulting free bis-NHC, $\mathbf{G}^{\mathbf{t} \mathbf{B u}}$, which is stable in $\mathrm{C}_{6} \mathrm{D}_{6}$ solution for several days, was characterized by NMR spectroscopy.
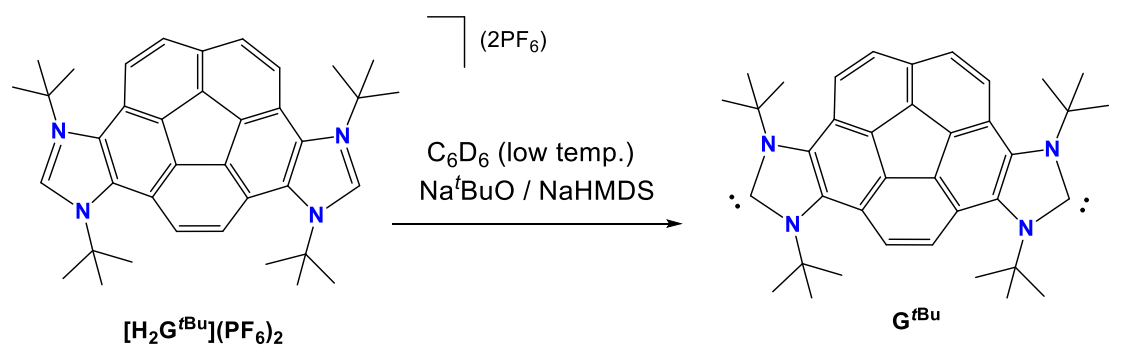

Scheme 4.3. Isolation of bis-N-heterocyclic carbene ligand $\mathbf{G}^{\mathbf{t}^{\mathbf{B u}}}$

The ${ }^{13} \mathrm{C}\left\{{ }^{1} \mathrm{H}\right\}$ NMR spectrum of $\mathbf{G}^{\mathbf{t} \mathbf{B u}}$ displayed the diagnostic signal of the carbene carbon at $219.89 \mathrm{ppm}$, in the same region as shown by other previously published 
benzimidazole-based carbenes. ${ }^{[2 e, 13 b, 21]}$ All other details regarding the ${ }^{13} \mathrm{C}\left\{{ }^{1} \mathrm{H}\right\}$ NMR spectrum may be found in the Experimental Section (Chapter 5). The ${ }^{1} \mathrm{H}$ NMR spectrum of $\mathbf{G}^{t^{\mathbf{B u}}}$ is described below.

\section{${ }^{1} H$ NMR spectrum of $\boldsymbol{G}^{\boldsymbol{t} \boldsymbol{B} u}$}

Figure 4.4 shows the ${ }^{1} \mathrm{H}$ NMR spectrum of an in situ prepared solution of $\mathbf{G}^{t \mathbf{B u}}$ in $\mathrm{C}_{6} \mathrm{D}_{6}$. The absence of the acidic signal of the $\mathrm{NCHN}$ groups of the salt precursor is an indication of the deprotonation of $\left[\mathbf{H}_{2} \mathbf{G}^{t \mathbf{B u}}\right]\left(\mathbf{P F}_{\mathbf{6}}\right)_{2}$. The signals corresponding to the protons of corannulene core $(\mathbf{a}, \mathbf{b}$ and $\mathbf{c})$ are displayed at $8.55,8.48$ and $7.86 \mathrm{ppm}$, respectively. In addition, the signal due to the protons of the tert-butyl groups appears at $2.09 \operatorname{ppm}(\mathbf{d})$.

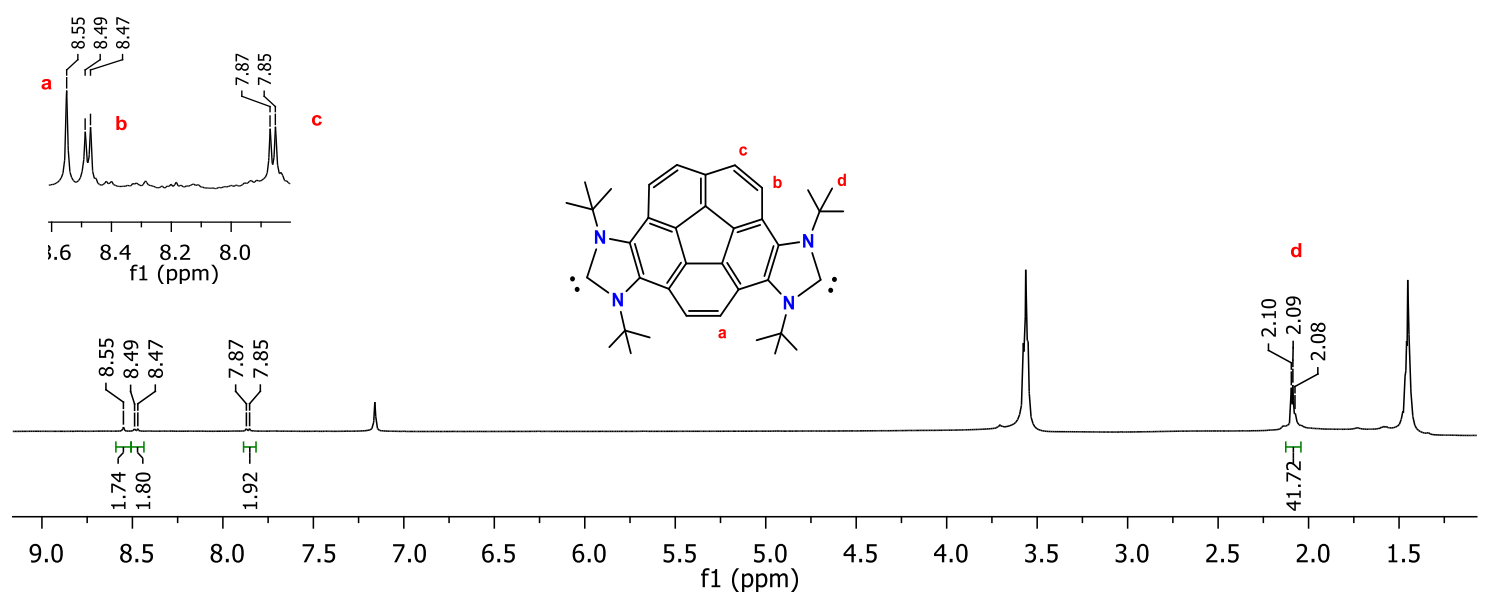

Figure 4.4. ${ }^{1} \mathrm{H}$ NMR spectrum of $\mathbf{G}^{\boldsymbol{t}^{\mathrm{Bu}}}$ in $\mathrm{C}_{6} \mathrm{D}_{6}$

\subsubsection{Coordination of corannulene-based bis-NHCs}

The coordination abilities of the bis-NHC ligands resulting from the deprotonation of the bis-azoliums $\left[\mathbf{H}_{2} \mathbf{G}^{n \mathbf{B u}}\right]\left(\mathbf{P F}_{6}\right)_{2}$ and $\left[\mathbf{H}_{\mathbf{2}} \mathbf{G}^{t \mathbf{B u}}\right]\left(\mathbf{P F}_{6}\right)_{2}$ (Chart 4.4) were probed by using $[\mathrm{RhCl}(\mathrm{COD})]_{2}$ and $\left[\mathrm{AuCl}\left(\mathrm{SMe}_{2}\right)\right]$ as metal sources. In the following sections, the preparation and characterization of the complexes $\mathbf{1 G}^{\boldsymbol{n} \mathbf{B u}}, \mathbf{2} \mathbf{G}^{\mathbf{n} \mathbf{B u}}$ and $\mathbf{3 G}^{t \mathbf{B u}}$ will be described. 

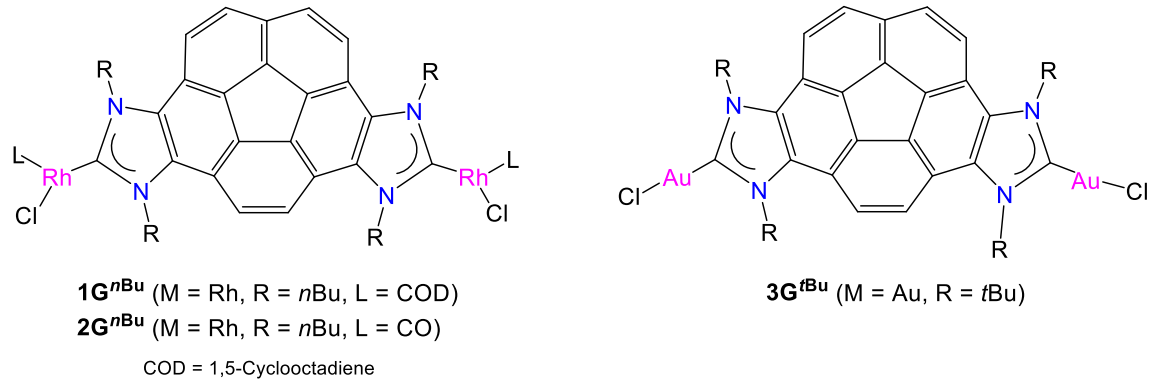

Chart 4.4. Bimetallic complexes $1 \mathrm{G}^{n \mathrm{Bu}}, \mathbf{2 \mathrm { G } ^ { n \mathrm { Bu } }}$ and $\mathbf{3} \mathrm{G}^{\mathrm{tBu}}$

\subsubsection{Synthesis and characterization of rhodium complexes}

The corannulene-based bis-NHC rhodium complexes $\mathbf{1 G}^{\mathbf{B} \mathbf{B u}}$ and $\mathbf{2 G}^{\boldsymbol{n} \mathbf{B u}}$ were obtained following the synthetic route depicted in Scheme 4.4. The reaction between $\left[\mathbf{H}_{2} \mathbf{G}^{n \mathbf{B u}}\right]\left(\mathbf{P F}_{\mathbf{6}}\right)_{2}$ and $[\mathrm{RhCl}(\mathrm{COD})]_{2}$ in refluxing acetone in the presence of $\mathrm{K}_{2} \mathrm{CO}_{3}$, allowed the preparation the di-rhodium complex $\mathbf{1 G}^{\mathbf{n} \mathbf{B u}}$ in $30 \%$ of yield (Scheme 4.4). The related tetra-carbonylated complex $\mathbf{2 G}^{\mathbf{n} \mathbf{B u}}$, was obtained by bubbling $\mathrm{CO}$ through a dichloromethane solution of $\mathbf{1 G}^{\mathbf{n} \mathrm{Bu}}$ at $0{ }^{\circ} \mathrm{C}$.

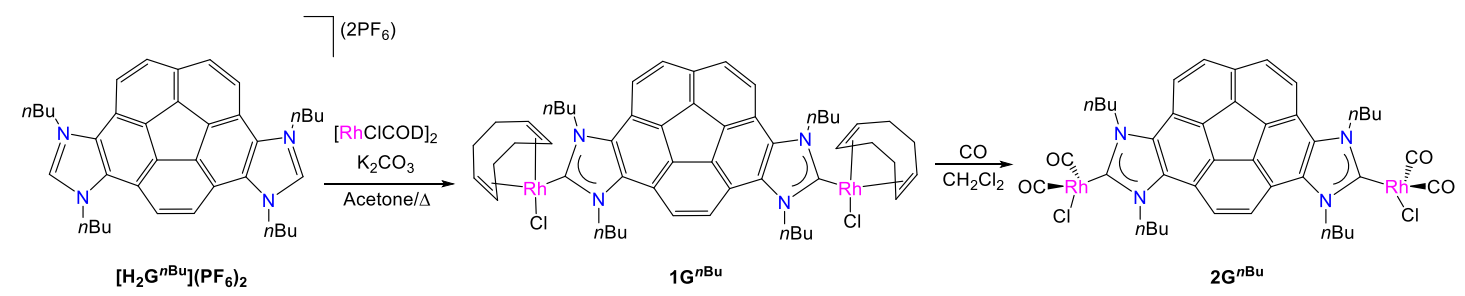

Scheme 4.4. Synthesis of complexes $\mathbf{1 G}^{\mathbf{B u}}$ and $\mathbf{2 G}^{\boldsymbol{n}^{\mathrm{Bu}}}$

Both complexes were characterized by NMR spectroscopy, Mass Spectrometry and Elemental Analysis. The ${ }^{1} \mathrm{H}$ and ${ }^{13} \mathrm{C}\left\{{ }^{1} \mathrm{H}\right\}$ NMR spectra are consistent with their predicted two-fold symmetries. Single resonances due to the metallated carbene carbons are found in the ${ }^{13} \mathrm{C}\left\{{ }^{1} \mathrm{H}\right\}$ NMR spectra, showing the characteristic ${ }^{1} J_{\mathrm{Rh}-\mathrm{C}}$ couplings $\left(\mathbf{1 G}^{\mathbf{n B u}}\right.$ : 190.5 ppm, $\left.{ }^{1} J_{\mathrm{Rh}-\mathrm{C}}=52 \mathrm{~Hz} ; \mathbf{2 G}^{\mathbf{n B u}}: 185.14 \mathrm{ppm},{ }^{1} J_{\mathrm{Rh}-\mathrm{C}}=54 \mathrm{~Hz}\right)$.

As an illustrative example, the ${ }^{1} \mathrm{H}$ and ${ }^{13} \mathrm{C}\left\{{ }^{1} \mathrm{H}\right\}$ NMR spectra of $\mathbf{1 G}^{\mathbf{n} \mathbf{B u}}$ are described below. All details regarding the characterization of $\mathbf{2 G}^{\mathbf{n} \mathbf{B u}}$ can be found in the Experimental Section (Chapter 5).

\section{${ }^{1} H$ NMR spectrum of $\mathbf{1 G}^{\mathbf{B} \boldsymbol{u}}$}

Figure 4.5 shows the ${ }^{1} \mathrm{H}$ NMR spectrum of $\mathbf{1 G}^{\mathbf{n} \mathrm{Bu}}$. The absence of the signal due to the protons of the $\mathrm{NCHN}$ groups, and the appearance of the signals corresponding to the COD ligand are indicative of the coordination of the bis-NHC ligand $\mathbf{G}^{n \mathbf{B u}}$ to the $\mathrm{Rh}^{(\mathrm{I})}$ 
fragment. The signals assigned to the protons of the corannulene core $(\mathbf{a}, \mathbf{b}$ and $\mathbf{c})$ are displayed at $8.17,8.05$ and $8.02 \mathrm{ppm}$, respectively. The signals due to the protons of the $n$-butyl groups appear at 5.21, 2.05, 1.83 and $1.24 \mathrm{ppm}$ (d, e, f and $\mathbf{g}$, respectively). The rest of the signals corresponding to the protons of the COD ligands are shown on the spectrum.

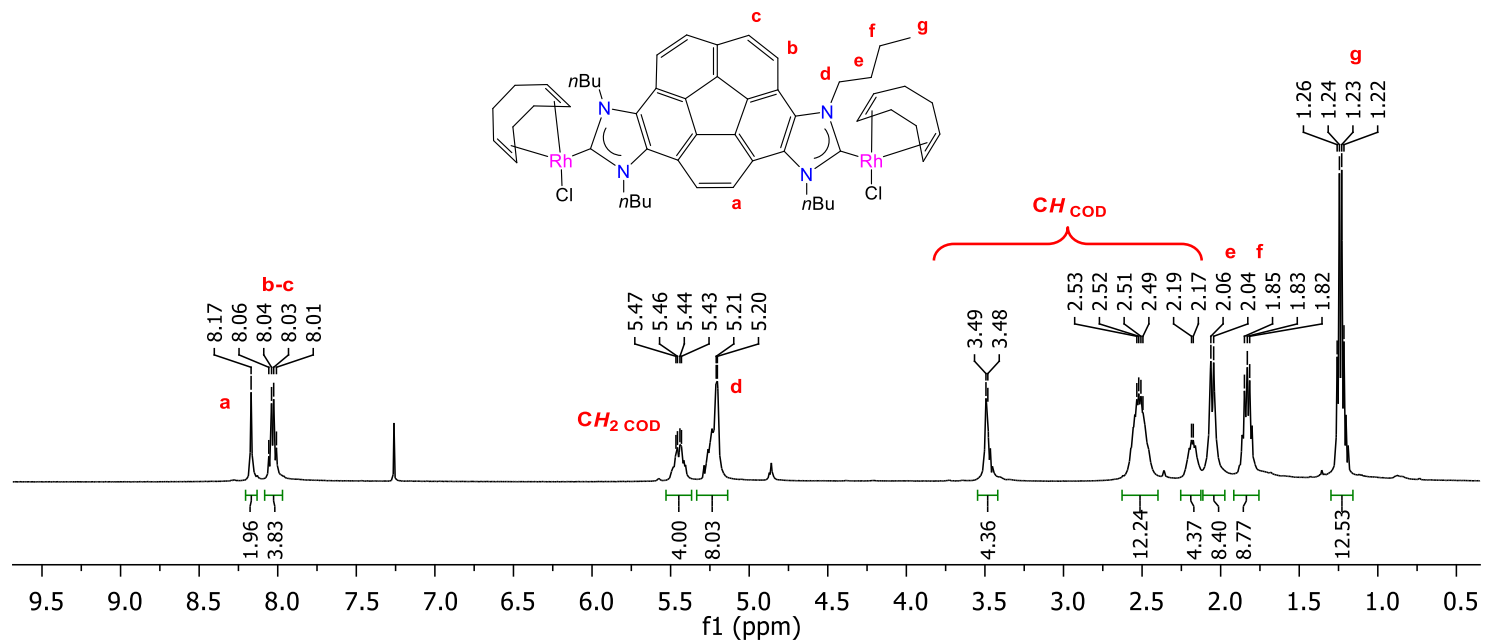

Figure 4.5. ${ }^{1} \mathrm{H}$ NMR spectrum of $\mathbf{1 G}^{\boldsymbol{n} \mathrm{Bu}}$ in $\mathrm{CDCl}_{3}$

\section{${ }^{13} C\left\{{ }^{1} H\right\} N M R$ spectrum of $\mathbf{1 G}^{\mathbf{n B u}}$}

Figure 4.6 shows the ${ }^{13} \mathrm{C}\left\{{ }^{1} \mathrm{H}\right\}$ NMR spectrum of $\mathbf{1 G}^{\mathbf{n} \mathbf{B u}}$. The most characteristic signal is the doublet attributed to the metallated carbene-carbon (1) at $190.5 \mathrm{ppm}\left({ }^{1} J_{\mathrm{Rh}-\mathrm{C}}=52\right.$ $\mathrm{Hz}$ ). The signals assigned to the corannulene core are shown between 133.5-117.9 ppm. The signals due to the carbons of the $n$-butyl groups appear between 33.4 and $14.3 \mathrm{ppm}$. The rest of the signals corresponding to the COD carbons are conveniently displayed on the spectrum.

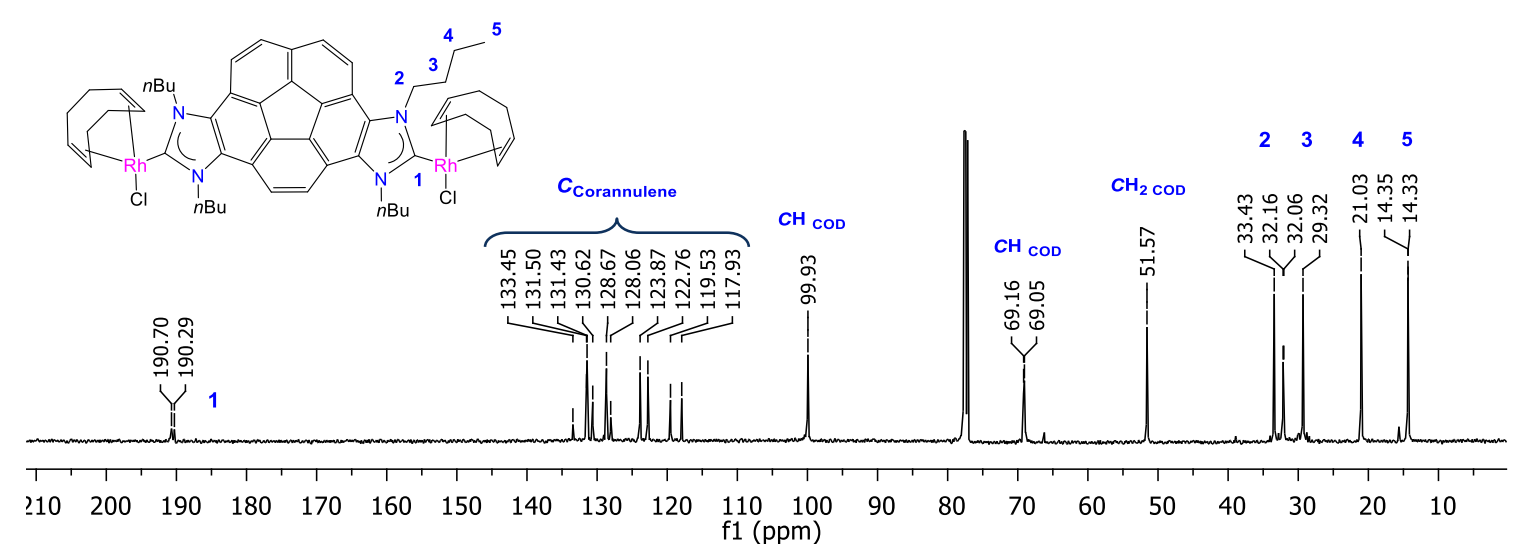

Figure 4.6. ${ }^{13} \mathrm{C}\left\{{ }^{1} \mathrm{H}\right\}$ NMR spectrum of $\mathbf{1 G}^{\boldsymbol{n}}{ }^{\mathrm{Bu}}$ in $\mathrm{CDCl}_{3}$ 


\subsubsection{Synthesis and characterization of a gold complex}

The corannulene-based bis-NHC $\mathbf{G}^{t \mathbf{B u}}$ ligand presents a very large steric bulk around the carbene carbon, due to the spatial orientation of the tert-butyl wingtips, where two methyl groups are enforced towards the coordination sphere of the metal (Chart 4.3). We envisaged that the coordination of this ligand should only be possible if a linear metal complex was obtained. For this reason, we decided to try the coordination of this bis-NHC ligand to $\mathrm{Au}^{(\mathrm{I})}-\mathrm{Cl}$.

The reaction of $\left[\mathbf{H}_{\mathbf{2}} \mathbf{G}^{\mathbf{t} \mathbf{B u}}\right]\left(\mathbf{P F}_{\mathbf{6}}\right)_{\mathbf{2}}$ with $\left[\mathrm{AuCl}\left(\mathrm{SMe}_{2}\right)\right]$ in THF, in the presence of KHMDS, afforded the bis-NHC complex $\left(\mathbf{3 G}^{t \mathbf{B u}}\right)$ in moderate yield (40\%) (Scheme 4.5). The gold complex $\mathbf{3 G}^{\boldsymbol{t}^{\mathrm{Bu}}}$ was characterized by NMR spectroscopy, Mass Spectrometry and Elemental Analysis. The mass spectrum (ESI-TOF-MS) of the complex revealed two main peaks at $\mathrm{m} / \mathrm{z}$ ratios of 787.3 and 1041.3 , which were assigned to $[\mathrm{M}-\mathrm{AuCl}+\mathrm{H}]^{+}$and $[\mathrm{M}+\mathrm{Na}]^{+}$, respectively. The ${ }^{13} \mathrm{C}\left\{{ }^{1} \mathrm{H}\right\}$ NMR spectrum of complex $\mathbf{3 G}^{\boldsymbol{t}^{\mathbf{B u}}}$ displayed a signal at $178.72 \mathrm{ppm}$, assigned to the resonance of the carbene carbon.

The ${ }^{1} \mathrm{H}$ NMR spectrum of $\mathbf{3 G}^{\mathbf{t} \mathbf{B u}}$ is described below. All other details regarding the full characterization of $\mathbf{3 G}^{\boldsymbol{t}^{\mathbf{B u}}}$ may be found in the Experimental Section (Chapter 5).
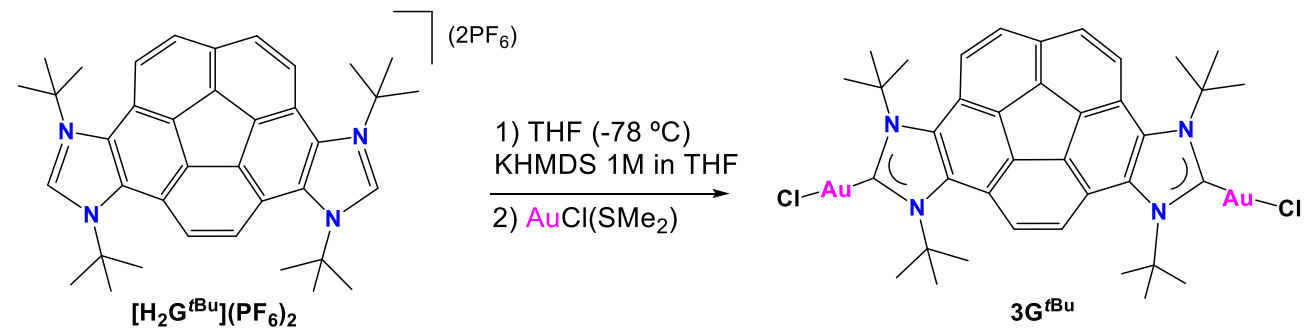

Scheme 4.5. Synthesis of complex $\mathbf{3 G}^{\mathrm{tBu}}$

\section{${ }^{1} H$ NMR spectrum of $3 \boldsymbol{G}^{\text {tBu }}$}

Figure 4.7 shows the ${ }^{1} \mathrm{H}$ NMR spectrum of $\mathbf{3 G}^{\mathbf{t B u}}$. The absence of the signal due to the protons of the $\mathrm{NCHN}$ groups is the first indication that the coordination of the bis-NHC ligand $\mathbf{G}^{\mathbf{t} \mathbf{u} u}$ to the $\mathrm{Au}^{(\mathrm{I})}$ fragment has taken place. The signals assigned to the protons of the corannulene core $(\mathbf{a}, \mathbf{b}$ and $\mathbf{c})$ are displayed at 8.39-8.34 and $7.97 \mathrm{ppm}$. The signals due to the protons of the four tert-butyl groups appear at $2.37 \mathrm{ppm}$ (d) 


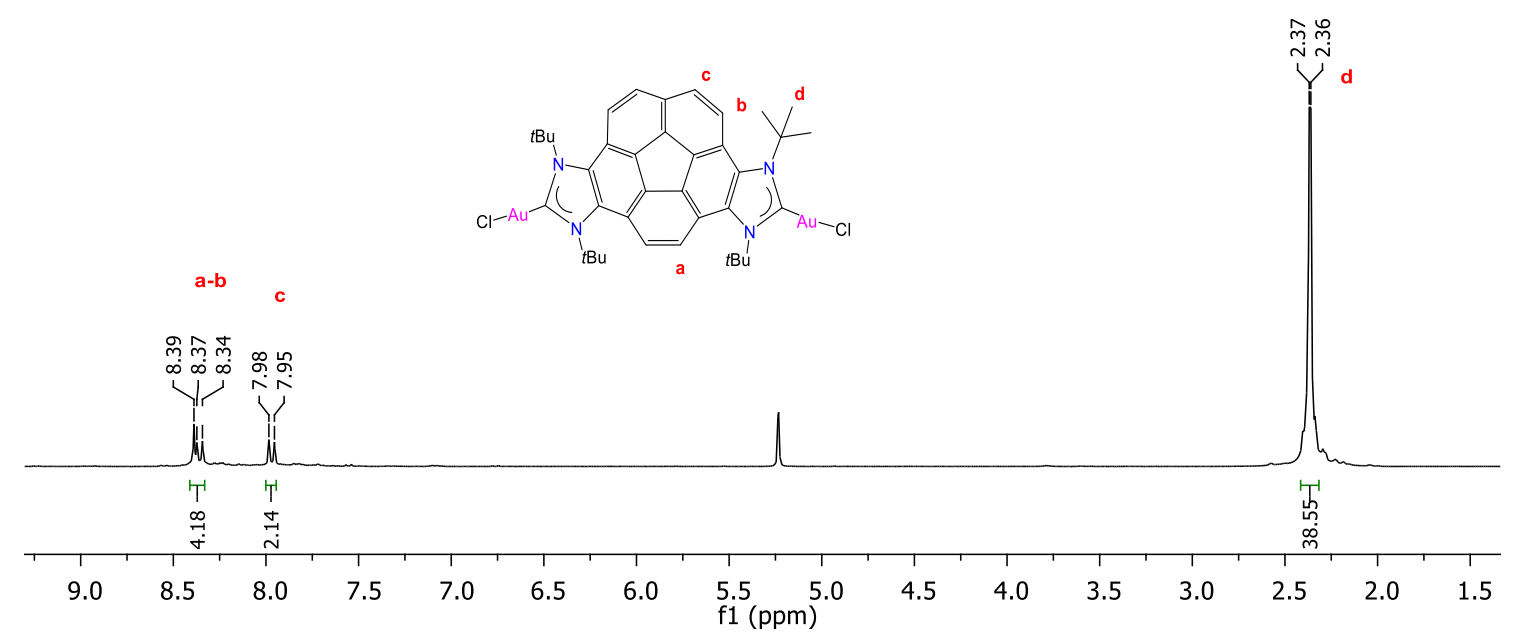

Figure 4.7. ${ }^{1} \mathrm{H}$ NMR spectrum of $3 \mathrm{G}^{\mathbf{t}}{ }^{\mathrm{Bu}}$ in $\mathrm{CD}_{2} \mathrm{Cl}_{2}$

\subsubsection{Electronic properties of the corannulene-based bis-NHC ligand}

The electron-donating strength of the ligand $\mathbf{G}^{\boldsymbol{n} \mathbf{B u}}$ in complexes $\mathbf{1 G}^{\mathbf{n} \mathbf{B u}}$ and $\mathbf{2} \mathrm{G}^{\boldsymbol{n} \mathbf{B u}}$, was experimentally evaluated by means of Cyclic Voltammetry (CV) and Infrared spectroscopy (IR).

\section{Electronic studies}

The cyclic voltammetry diagram of the bis- $\mathrm{Rh}^{(\mathrm{I})}$ complex $\mathbf{1 G}^{\boldsymbol{n} \mathbf{B u}}$ is shown in Figure 4.8, along with the relevant section of the Differential Pulse Voltammetry (DPV) plot. The complex showed an irreversible redox event at $\mathrm{E}_{\text {oxid }}=1.07 \mathrm{~V}$, which is attribuited to the $\mathrm{Rh}^{(\mathrm{I})} / \mathrm{Rh}^{(\mathrm{II})}$ couple.

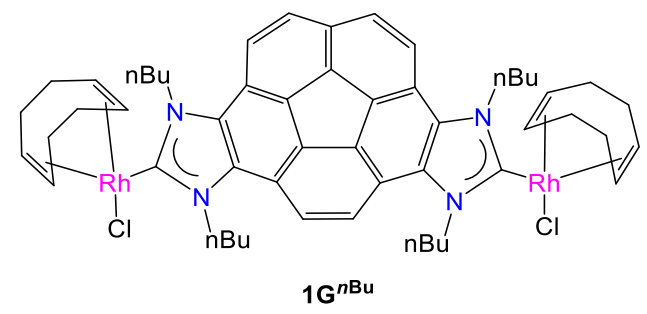

Chart 4.5. Bimetallic rhodium derivative

The analysis of the DPV generated for $\mathbf{1 G}^{n \mathbf{B u}}$, indicates that there is only one rhodiumcentered redox event taking place, thus indicating that the bi-metallic complex $\mathbf{1 G}^{\mathbf{B} \mathbf{B u}}$ contains two essentially decoupled rhodium fragments. 

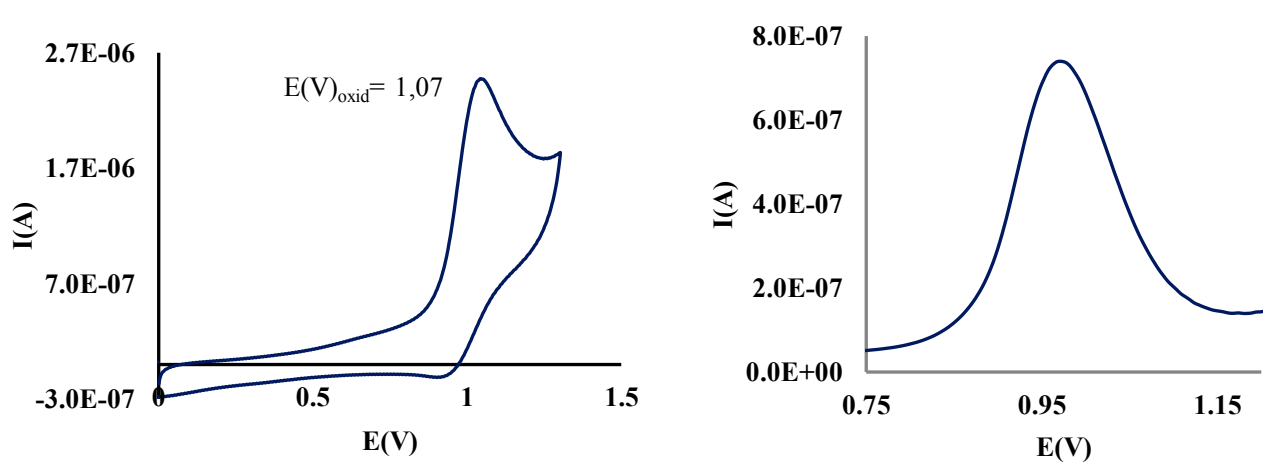

Figure 4.8. CV plot (left) and relevant DPV section (right) of complex $\mathbf{1 G}^{\mathbf{n B u}}\left(1 \mathrm{mM}\right.$ in dry $\mathrm{CH}_{2} \mathrm{Cl}_{2}$ with $0.1 \mathrm{M}\left[\mathrm{NBu}_{4}\right]\left[\mathrm{PF}_{6}\right]$ as the supporting electrolyte, $50 \mathrm{mVs}^{-1}$ scan rate, $\mathrm{Fc}^{+} / \mathrm{Fc}$ used as internal standard with $\left.\mathrm{E}_{1 / 2}\left(\mathrm{Fc} / \mathrm{Fc}^{+}\right)=0.44 \mathrm{~V} v s . \mathrm{SCE}\right)$.

\section{$\underline{\text { IR studies and Tolman Electronic Paramenter (TEP) }}$}

The electron-donating strength of our bis-NHC ligand can also be determined by studying the IR spectrum of the rhodium tetracarbonyl complex $\mathbf{2} \mathbf{G}^{\mathbf{n} \mathbf{B u}}$.

The IR spectrum of $\mathbf{2} \mathbf{G}^{\mathbf{n} \mathbf{B u}}$ was carried out in $\mathrm{CH}_{2} \mathrm{Cl}_{2}$ solution, and showed two $\mathrm{CO}$ stretching bands at 2083 and $2003 \mathrm{~cm}^{-1}$. The average value of the two stretching frequencies $\left(v_{\mathrm{av}}(\mathrm{CO})\right)$ is $2043.0 \mathrm{~cm}^{-1}$, from which a TEP value of $2055.0 \mathrm{~cm}^{-1}$ can be derived by employing the well-known correlations. ${ }^{[17,22]}$

In addition, the DFT calculated $\mathrm{TEP}^{[23]}$ value for $\mathbf{G}^{\mathbf{n} \mathbf{B u}}$ (determined by Prof. Dmitri Gusev, from the Wilfrid Laurier University) is $2054 \mathrm{~cm}^{-1}$, thus differing only in one TEP unit from the experimental one.

Table 4.1. Carbonyl stretching frequencies and TEP $\left(\mathrm{cm}^{-1}\right)$

\begin{tabular}{|c|c|c|c|}
\hline Complex & $v(C O)_{a v}\left(\mathrm{~cm}^{-1}\right)$ & $\begin{array}{c}\text { TEP } \\
\text { (calculated) }\end{array}$ & TEP (from DFT) \\
\hline $2 \mathrm{G}^{n \mathrm{Bu}}$ & 2043.0 & 2055.0 & 2054.0 \\
\hline $\mathrm{nBu}$ & 2026.8 & $2052.7^{[24]}$ & - \\
\hline
\end{tabular}

Scheme 4.6 displays the calculated TEP values of a series of NHCs bearing $n \mathrm{Bu}$ Nsubstituents. From the data shown, it can be observed that there is a large difference between the TEP value of the imidazolylidene $\left(\mathrm{I}^{n} \mathrm{Bu}\right)$ and the rest of the NHC ligands bearing aromatic rings at the backbone, all showing lower electron-donating character. The difference in the electron-donating character of all three arene-decorated NHCs is 
very similar, with a maximum difference of $0.7 \mathrm{~cm}^{-1}$ between the TEP values shown for the benzoimidazolylidene and our corannulene-bis-NHC.

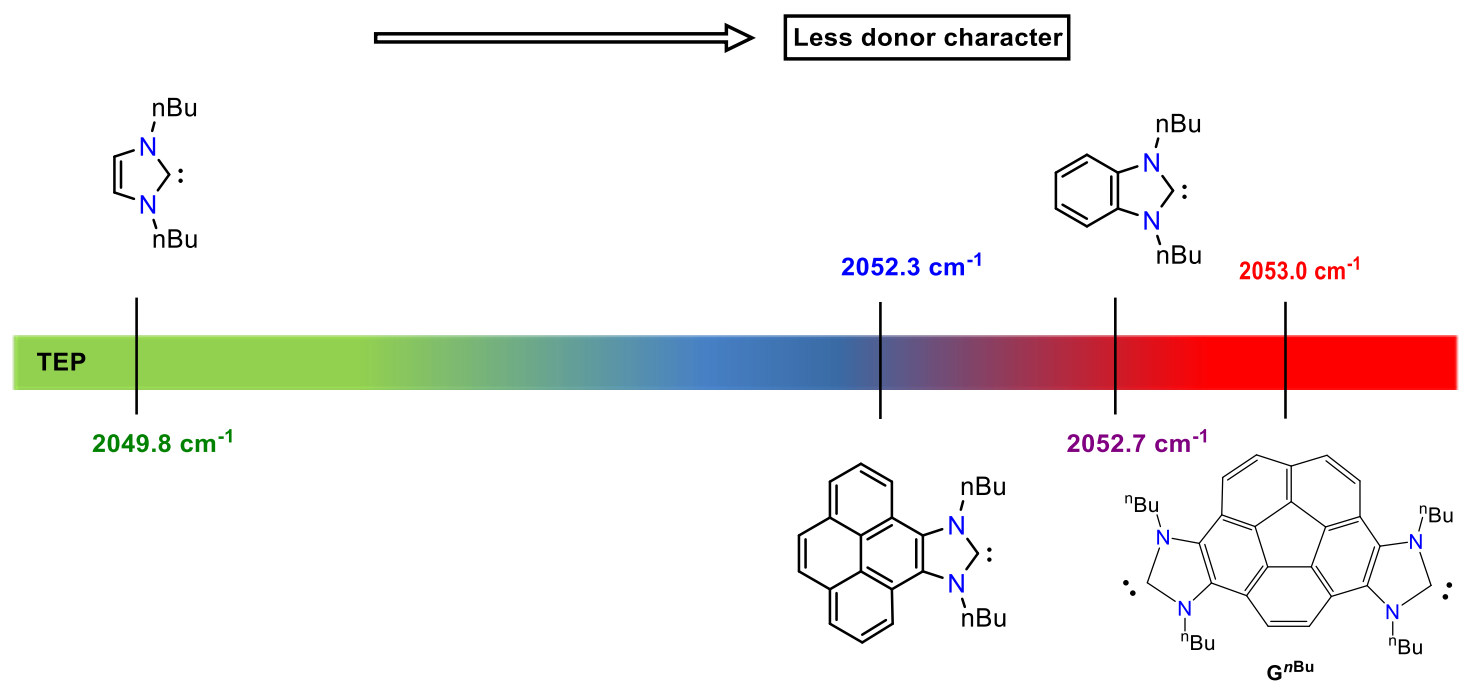

Scheme 4.6. Variation of the TEP $\left(\mathrm{cm}^{-1}\right)$ values of some NHC ligands

\subsubsection{Catalytic studies of the corannulene-bis-NHC di-Au ${ }^{(\mathrm{I})}$ complexes}

As previously stated in the introduction, our research group has been recently working on the design and development of poly-N-heterocyclic carbene ligands linked by polycyclic aromatic hydrocarbons. ${ }^{[25]}$ The ultimate goal was the preparation of homogeneous metal-based catalysts with enhanced properties. ${ }^{[2]}$ In particular, the use of polymetallic metal complexes based on a polyaromatic core allowed the supramolecular interaction of the ligand with the substrates, enhancing their catalytic performance, exhibiting better activity than their related monometallic counterpart lacking this polycyclic aromatic core. Among them, two trimetallic gold complexes featuring electron deficient polyaromatic ligands resulted in very efficient catalysts towards the hydroamination of alkynes. ${ }^{[2 \mathrm{~d}, 26]}$ It is worth mentioning that the catalytic activity of gold catalysts has often been related to the ability of the gold center to behave as an electrophile. For this reason and given the low electron-donating character of the corannulene based bis-NHC ligand in $\mathbf{G}^{n^{\mathbf{B u}}}$, we chose $\mathbf{3} \mathbf{G}^{\mathbf{t} \mathbf{u}}$ to evaluate its catalytic activity against two different catalytic transformations: the hydroamination of alkynes and the cyclization reaction of 2,5-dimethylfuran with alkynes because we thought that this complex should yield good catalytic efficiencies.

Unfortunately, as will be described in the following section, the catalytic performance of $\mathbf{3} \mathbf{G}^{\mathbf{t} \mathbf{B u}}$ towards both catalytic processes resulted in low activities. 


\section{Hydroamination of alkynes}

The catalytic activity of the bis-NHC-gold complex $\mathbf{3 G}^{t \mathbf{B u}}$ was tested towards the hydroamination of phenylacetylene using three different anilines (aniline, 2,4,6trimethylaniline and 2,6-diisopropylaniline) following the methodology reported in the literature. ${ }^{[2 \mathrm{~b}, \mathrm{~d}, 27]}$

Table 4.2 summarizes the catalytic results. The reactions were carried out at $90{ }^{\circ} \mathrm{C}$ in acetonitrile, in the presence of $\mathrm{AgBF}_{4}$ and using a catalyst loading of $0.5 \mathrm{~mol} \%$ during 6 hours.

Table 4.2. Hydroamination of Phenylacetylene with arylamines
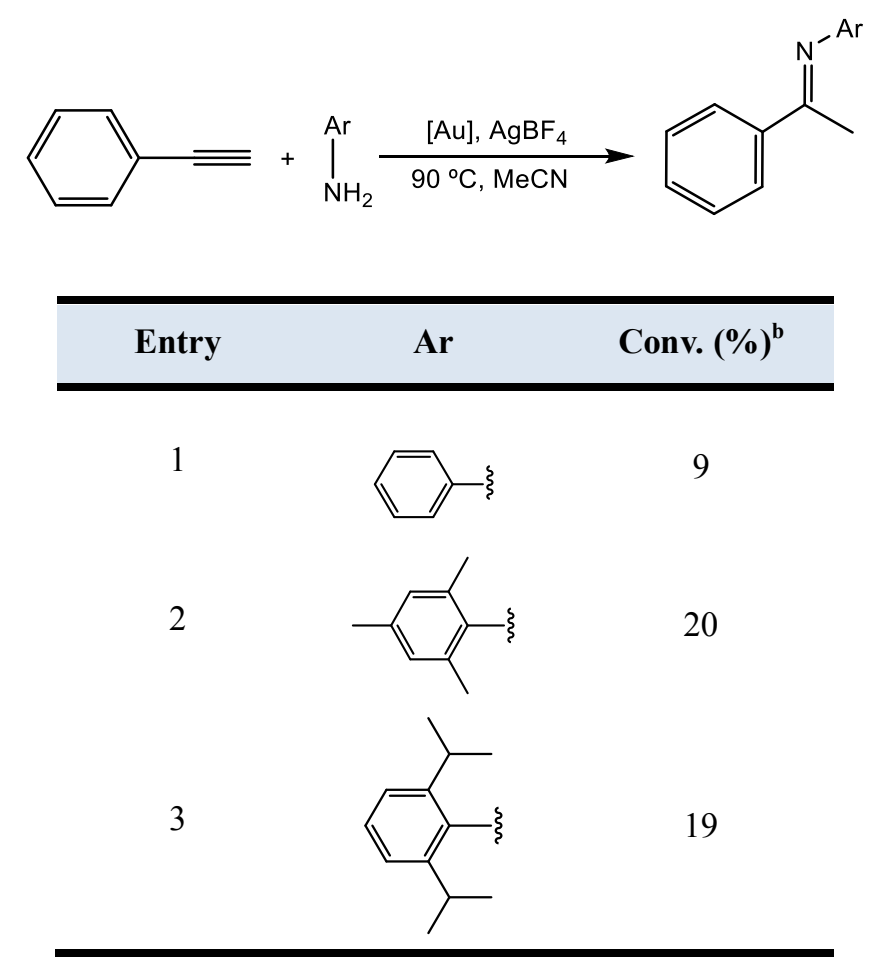

${ }^{\text {a }}$ Reaction conditions: $0.5 \mathrm{mmol}$ of phenylacetylene, $0.55 \mathrm{mmol}$ of aryl amine, $0.5 \mathrm{~mol} \%$ of the catalyst, $1 \mathrm{~mol} \%$ of $\mathrm{AgBF}_{4}, 1 \mathrm{~mL}$ of dry $\mathrm{CH}_{3} \mathrm{CN}$ at $90{ }^{\circ} \mathrm{C}, 6 \mathrm{~h}$. ${ }^{\mathrm{b}} \mathrm{Conversions} \mathrm{determined} \mathrm{by} \mathrm{gas} \mathrm{chromatography}$ (GC), using anisole as internal standard

\section{Cyclization of 2,5-dimethylfuran with terminal alkynes}

In view of the poor catalytic performances observed in the hydroamination of alkynes, we decided to test a different catalytic reaction. In this case, we betted on the synthesis of phenols obtained by cyclization reaction of 2,5-dimethylfuran with alkynes. ${ }^{[28]}$ The reactions were carried out following a method previously described, where 2,5dimethylfuran is reacted at room temperature with the alkyne in dichloromethane, using 
$1.5 \mathrm{~mol} \%$ of catalyst and $1.5 \mathrm{~mol} \%$ of $\mathrm{NaBArF}$ (tetrakis[3,5bis(trifluoromethyl)phenyl]borate]) during 24 hours.

Table 4.3. Intermolecular gold(I)-catalyzed cyclization of 2,5-dimethylfuran with terminal alkynes

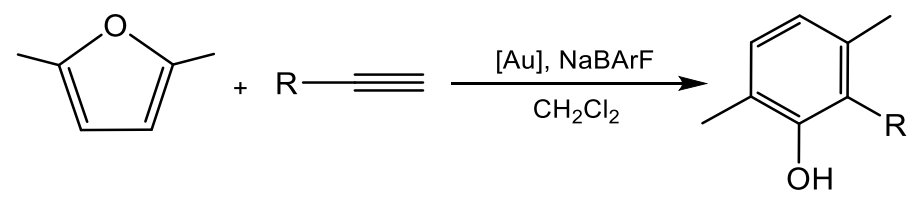

\begin{tabular}{cccc}
\hline Entry & Alkyne & Temperature & Yield (\%) \\
\hline 1 & phenylacetylene & R.T & 17 \\
2 & phenylacetylene & $40{ }^{\circ} \mathrm{C}$ & 29 \\
3 & 1-octyne & $40{ }^{\circ} \mathrm{C}$ & - \\
4 & 3-ethynyltoluene & $40^{\circ} \mathrm{C}$ & 14 \\
\hline
\end{tabular}

aConditions: $2 \mathrm{mmol}$ of 2,5-dimethylfuran, $1 \mathrm{mmol}$ of alkyne, $1.5 \mathrm{~mol} \%$ of the catalyst, 1.5 mol \% of $\mathrm{NaBArF}$, dry $\mathrm{CH}_{2} \mathrm{Cl}_{2}, 24 \mathrm{~h}$. ${ }^{\text {Y }}$ Yields of the isolated products

The low performance of complex $\mathbf{3 G}^{\mathbf{t} \mathbf{B u}}$ observed in both catalytic transformations was rather disappointing, and we ascribed to be likely due to catalyst decomposition during the reaction course. As a result of the poor catalytic activity shown by the di-gold complex, we considered the possibility of exploiting the size and shape of $\mathbf{3 G} \mathbf{G}^{\mathbf{t} \mathbf{B u}}$, as molecular receptor for fullerene recognition.

\subsubsection{Corannulene-bis-NHC di-Au ${ }^{(I)}$ complex and recognition of $\mathrm{C}_{60}$}

As mentioned in the introduction, bowl-shaped polyaromatic hydrocarbons, such as corannulene, are among the best binding motifs for the preparation of effective fullerene receptors. ${ }^{[29]}$ This is mainly due to the complementarity shape that exists between the shallow concave cavity of the corannulene and the convex surfaces of fullerenes. ${ }^{[3 c]}$ For this reason, and inspired by the existing literature, we decided to study the interaction of the bowl-shaped gold complex $\mathbf{3 G}^{\mathbf{t} \mathbf{B u}}$ with fullerene. Our studies were carried out by using different titration techniques, such as ${ }^{1} \mathrm{H}$ NMR spectroscopy, fluorescence spectroscopy and calorimetric studies, and were also supported by DFT calculations. 
We decided to use the di-gold complex $\mathbf{3 G}^{t \mathbf{B u}}$ for this study because we thought that the linear coordination of the metal fragment on the bis-NHC ligand should enhance the shape complementarity between the corannulene-based compound and fullerene, since the linear $\mathrm{AuCl}$ branches should probably behave as an extension of the receptor, increasing the contact surface with fullerenes. The corannulene rhodium complexes described in this chapter should show lower binding affinities due to the steric bulk provided by the more sterically crowded metal fragment.

\section{Host-guest studies by ${ }^{1} H$ NMR titrations}

We first studied the affinity of $\mathbf{3 G}^{\mathbf{t}^{\mathbf{B u}}}$ (host) versus two different shaped polyaromatic guests, fullerene $\left(\mathrm{C}_{60}\right)$ and coronene (Chart 4.6). With these two model substrates we aimed to illustrate the importance of shape complementarity on the binding affinities of our corannulene-based host compound.

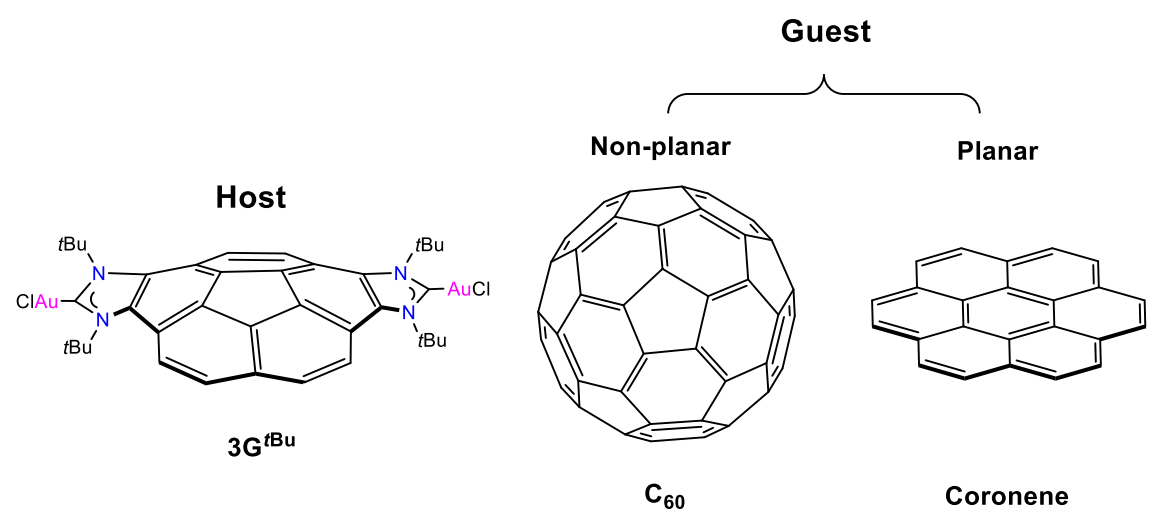

Chart 4.6. Host $\left(\mathbf{3 G}^{\mathbf{t} \mathbf{B u}}\right)$ vs. Guest $\left(\mathrm{C}_{60}\right.$ and Coronene $)$

Toluene- $d_{8}$ was chosen as solvent for all titrations due to the optimal solubility observed for all reagents. In addition, the ${ }^{1} \mathrm{H}$ NMR spectrum of $\mathbf{3 G}^{\boldsymbol{t}^{\mathbf{B u}}}$ in toluene- $d_{8}$ solution showed sharp and well-defined signals in the aromatic region. The $\mathrm{H}_{\mathrm{a}}$ proton resonates as a singlet at $8.07 \mathrm{ppm}$, while the signals due to the protons $\mathrm{H}_{\mathrm{b}}$ and $\mathrm{H}_{\mathrm{c}}$ appear as two separated doublets at 8.08 and 7.56 ppm, respectively (see Figure 4.9). 


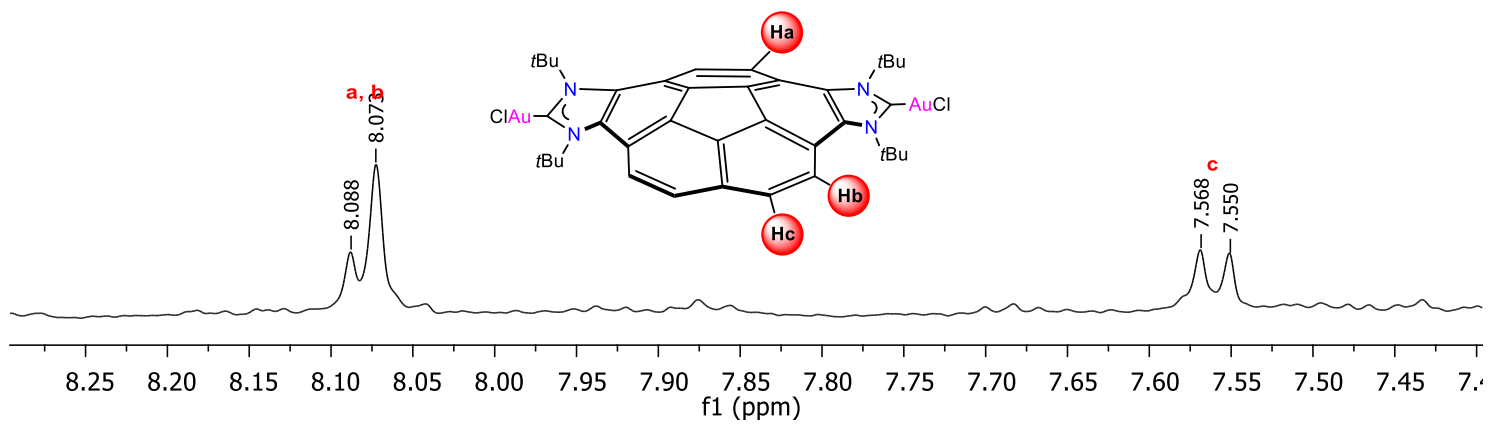

Figure 4.9. Representative region of the ${ }^{1} \mathrm{H}$ NMR spectrum of $\mathbf{3 G}^{\boldsymbol{t}^{\mathbf{B u}}}$ in toluene- $d_{8}$

The titrations were performed at constant concentrations of host $(1.55 \mathrm{mM})$. In order to do this, two solutions were prepared: a host solution $(1.55 \mathrm{mM})$ and a titrating solution that contained guest $(2 \mathrm{mM})$ and host $(1.55 \mathrm{mM})$. Unfortunately, we could not use higher concentrations of fullerene due to its low solubility in toluene. In a typical experiment, aliquots of titrant solution (guest + host) were gradually added into a NMR tube containing the titrand (host) solution.

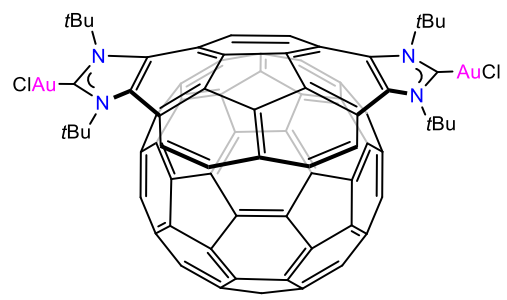

Chart 4.7. $\pi-\pi$ Donor-acceptor interactions between $\mathbf{3 G}^{t \mathbf{B u}}$ and $\mathrm{C}_{60}$

We observed that the incremental addition of $\mathrm{C}_{60}$ (guest) to the solution of $\mathbf{3 G}^{\mathbf{t} \mathbf{B u}}$ (host) induced a downfield shift of the corannulene proton signals in $\mathbf{3 G}^{\mathbf{t} \mathbf{B u}}$, as can be observed from the series of spectra shown in Figure 4.11. The addition of 0.5 equivalents of $\mathrm{C}_{60}$ produced a downfield shift of $0.4 \mathrm{ppm}$ for the signal assigned to $\mathrm{H}_{\mathrm{a}}$. The signals due to $\mathrm{H}_{b}$ and $\mathrm{H}_{\mathrm{c}}$ also experienced downfield shifts although to a lesser extent. The chemical shift changes experienced by the proton resonances of the corannulene unit in $\mathbf{3} \mathbf{G}^{\mathbf{t} \mathbf{B u}}$ are indicative of a binding process with $\mathrm{C}_{60}$ that showed fast kinetics on the NMR timescale. We assumed that the bimetallic complex $\mathbf{3 G}^{\mathbf{t} \mathbf{B u}}$ interacts with $\mathrm{C}_{60}$ through $\pi-\pi$ donoracceptor interactions.

Figure 4.10 shows the binding isotherm resulting from the representation of the chemical shift changes experienced by the signal of the $H_{a}$ proton in $\mathbf{3 G}^{\mathbf{t} \mathbf{B u}}$ during the 
titration with $\mathrm{C}_{60}$. Assuming the formation of a 1:1 binding complex, the nonlinear regression gave a good fit, and returned a binding constant of $\mathrm{K}_{11}=2750 \pm 300 \mathrm{M}^{-1}$ for the formation of a potential $\mathrm{C}_{60} @ \mathbf{3 G}^{\mathbf{t} \mathbf{B u}}$ complex.

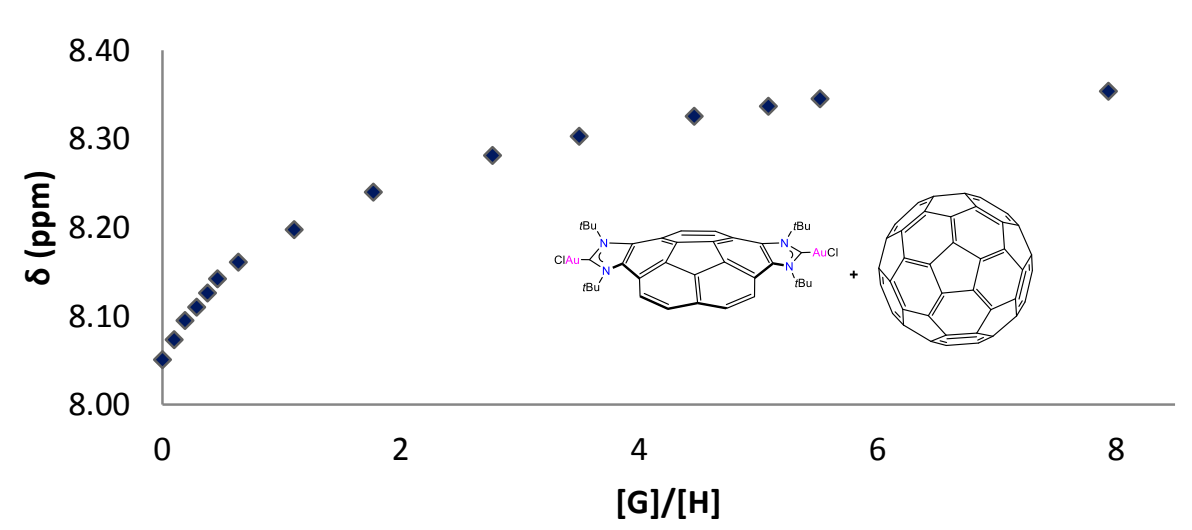

Figure 4.10. ${ }^{1} \mathrm{H}$ NMR chemical shifts $\delta(\mathrm{ppm})$ plotted against $[\mathrm{G}] /[\mathrm{H}]$.

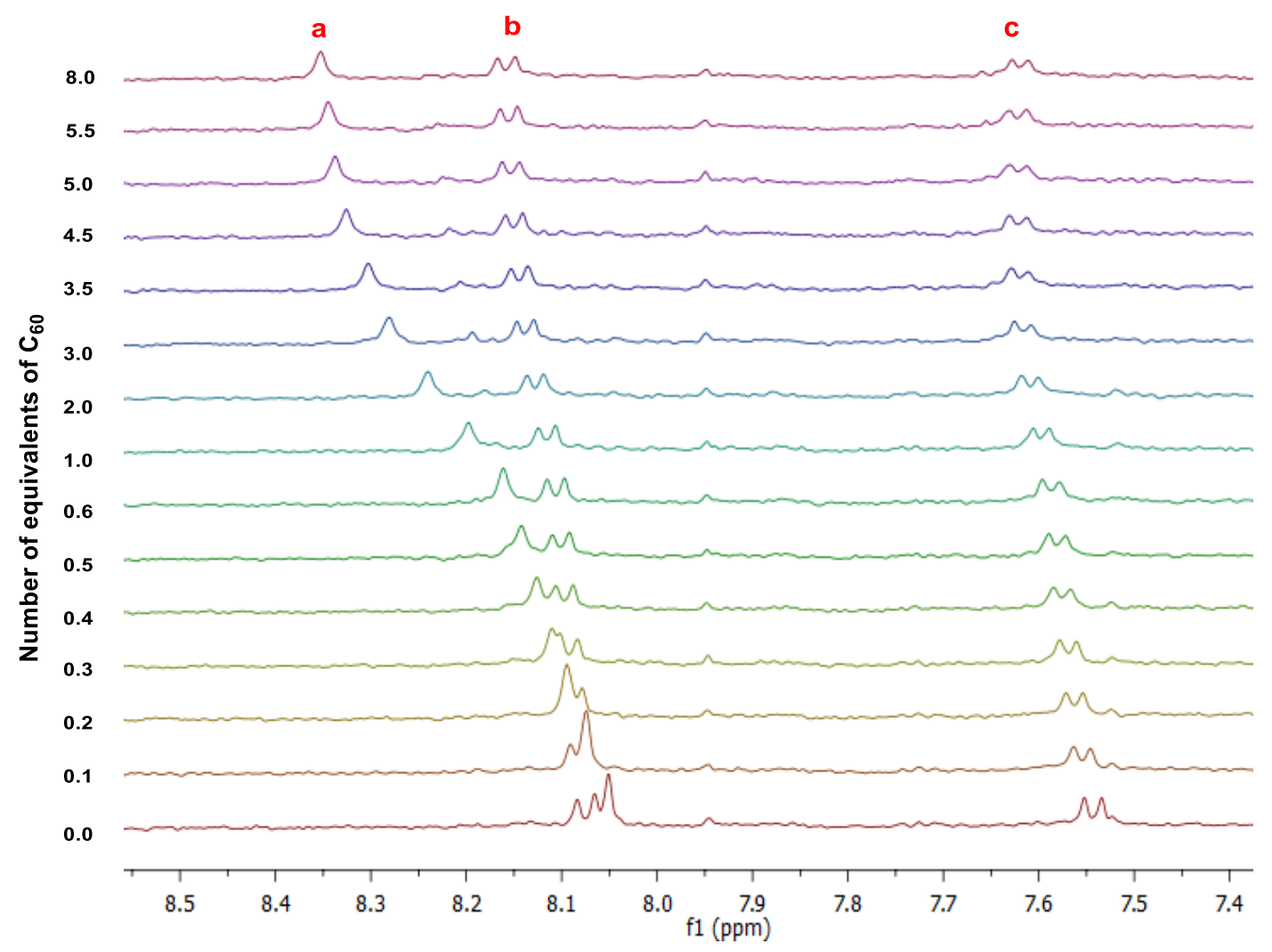

Figure 4.11. Selected regions of the ${ }^{1} \mathrm{H}$ NMR $\left(500 \mathrm{MHz}\right.$, toluene- $\left.d_{8}, 298 \mathrm{~K}\right)$ spectra acquired during the titration of $\mathbf{3 G}^{\mathbf{t} \mathbf{B u}}$ with incremental amounts of $\mathrm{C}_{60}$. The concentration of $\mathbf{3 G}^{\mathbf{t} \mathbf{B u}}$ was maintained constant $(1.55 \mathrm{mM})$ throughout the titration

The experimental data obtained in the NMR titration data with $\mathrm{C}_{60}$ also displayed good fits for 1:2 or 1:3 binding models. The analysis was performed by considering that the 
binding constants for the single binding steps leading to $\mathrm{C}_{60} @\left(\mathbf{3 G}^{\mathbf{t} \mathbf{B u}}\right)_{2}$ and $\mathrm{C}_{60} @\left(\mathbf{3 G}^{\mathbf{t} \mathbf{B u}}\right)_{3}$ were identical and independent, and returned a value that was coincident for the formation of 1:1 complex $\mathrm{K}_{\mathrm{a}}\left(\mathrm{C}_{60} @ \mathbf{3 G}^{t \mathbf{B u}}\right)=2750 \mathrm{M}^{-1}$. Unfortunately, the monotonic shift experienced by the analyzed proton signal of corannulene derivative $\mathbf{3 G}^{\mathbf{t} \mathbf{B u}}$ upon binding $\mathrm{C}_{60}$ did not allow us to establish an irrefutable binding model based on the fit of the NMR titration data.

Taking all this together, the results indicate that a) corannulene $\mathbf{3 G}^{\mathbf{t} \mathbf{B u}}$ interacts with $\mathrm{C}_{60}$ in solution at millimolar concentration, b) the chemical exchange between free and complexed $\mathbf{3 G}^{\boldsymbol{t}^{\mathrm{Bu}}}$ is fast on the NMR timescale; c) the binding constant for the interaction of $\mathbf{3 G}^{\mathbf{t} \mathbf{B u}}$ with $\mathrm{C}_{60}$ is on the order of $10^{3} \mathrm{M}^{-1}$, and d) most likely, complexes of larger stoichiometry than the simple 1:1 $\mathrm{C}_{60} @ \mathbf{3 G}^{\mathbf{t}}{ }^{\mathrm{u}}$ are formed in the investigated range of millimolar concentrations.

We were also interested in studying if $\mathbf{3 G}^{t \mathbf{B u}}$ could also be used as a receptor of planar polyaromatic hydrocarbons $(P A H S)$. As a model guest, we used coronene for our studies.

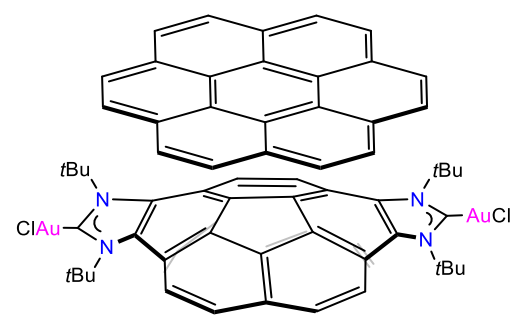

Chart 4.8. $\pi-\pi$ donor-acceptor interactions between $\mathbf{3 G}^{\mathbf{t} \mathbf{u} u}$ and coronene

The addition of incremental amounts of coronene to a millimolar solution of host $\mathbf{3 G}^{\mathbf{t} \mathbf{B u}}$ in toluene- $d_{8}$ produced changes in the chemical shift of all the siganals of aromatic protons of the host. The signals of $\mathrm{H}_{b}$ and $\mathrm{H}_{c}$ experienced a downfield shift whereas the signal of $\mathrm{H}_{\mathrm{a}}$ moved upfield. 


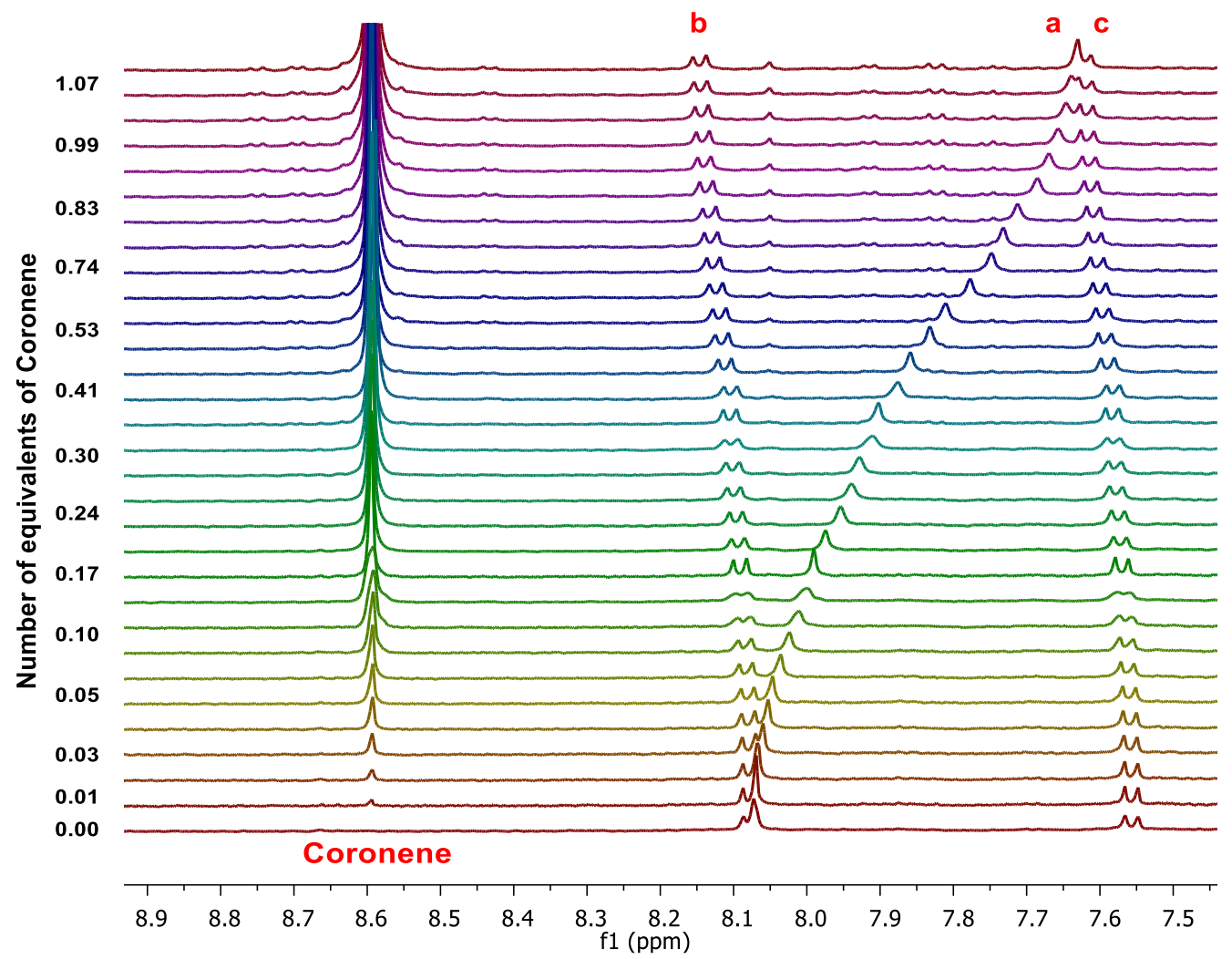

Figure 4.12. Selected regions of the ${ }^{1} \mathrm{H}$ NMR ( $500 \mathrm{MHz}$, toluene- $d_{8}, 298 \mathrm{~K}$ ) spectra acquired during the titration of $\mathbf{3} \mathbf{G}^{\mathbf{B u}}$ with incremental amounts of coronene. The concentration of $\mathbf{3 G}^{\mathbf{t} \mathbf{B u}}$ was maintained constant throughout the titration

The NMR titration data for the $\mathrm{H}_{\mathrm{a}}$ signal were mathematically analyzed using a 1:1 binding model. The fit was good and returned an association constant value for the formation of a coronene $@ 3 \mathbf{G}^{t \mathbf{B u}}$ complex of $\mathrm{K}_{11}=239 \pm 25 \mathrm{M}^{-1}$. This constant is significantly lower than that found for the binding with fullerene, pressumably as a consequence of the much lower shape complementarity. However, this result illustrates how the concave surface of corannulene can be adapted to the recognition of large planar polycyclic aromatic hydrocarbons.

\section{Host-guest studies by fluorescence spectroscopy}

In order to provide a further insight into the binding affinity of $\mathbf{3 G}^{\mathbf{t} \mathbf{B u}}$ and $\mathrm{C}_{60}$ in toluene, we carried out UV-Vis and fluorescence titrations. In these experiments, the host solution was transferred into an UV-cell and aliquots of the solution of host+guest were added, in the same way as in the NMR experiments. These spectrocopic techniques allow the use of lower concentrations than those required for ${ }^{1} \mathrm{H}$ NMR titrations. We carried out the fluorescence spectroscopy experiments with concentrations of $1.55 \times 10^{-5}$ 
$\mathrm{M}$ and $1.55 \times 10^{-4} \mathrm{M}$ for $\mathbf{3 G}^{\mathbf{t} \mathbf{B u}}$ and $\mathrm{C}_{60}$, respectively. By working at such low concentrations of $\mathbf{3 G}^{\mathbf{t} \mathbf{B u}}$, we expected to disfavour the formation of the aggregates of higher stoichiometry, e.g. 1:2 and 1:3 complexes, and therefore, to gain more information about the formation of the 1:1 inclusion complex. Unfortunately, the UVVis spectroscopic titration with $\mathrm{C}_{60}$ did not show any noticeable change in the absorption spectrum of $\mathbf{3 G}^{\mathbf{t} \mathbf{B u}}$. Conversely, the emission of $\mathbf{3} \mathbf{G}^{\mathbf{t} \mathbf{B u}}$ changed significantly in the presence of increasing amounts of $\mathrm{C}_{60}$. Figure 4.13 shows the changes observed in the emission spectra of $\mathbf{3 G}^{t \mathbf{B u}}\left(1.55 \times 10^{-5} \mathrm{M}\right)$ in toluene solution upon incremental addition of $\mathrm{C}_{60}$. The titration showed two phases. In the initial phase, the incremental addition of $\mathrm{C}_{60}$ provoked an increase in the intensity of the emission band of $\mathbf{3 G}^{\boldsymbol{t}^{\mathbf{B u}}}$ centered at $528 \mathrm{~nm}$. However, when the ratio of $\left[\mathrm{C}_{60}\right] /\left[\mathbf{3 G}^{t \mathbf{B u}}\right]>0.4$ the intensity of the emission band started to decrease. We inteprete this observation as a consequence of an absorption increase at the excitation wavelenght produced by the addition of $\mathrm{C}_{60}$ (inner filter effect). Consequently, the obtained emision titration data are not suitable for the mathematical analysis using theoretical binding models, but they clearly indicate that the interaction of $\mathbf{3 G}^{\mathbf{t} \mathbf{B u}}$ with $\mathrm{C}_{60}$ occurs even at micromolar concentration.

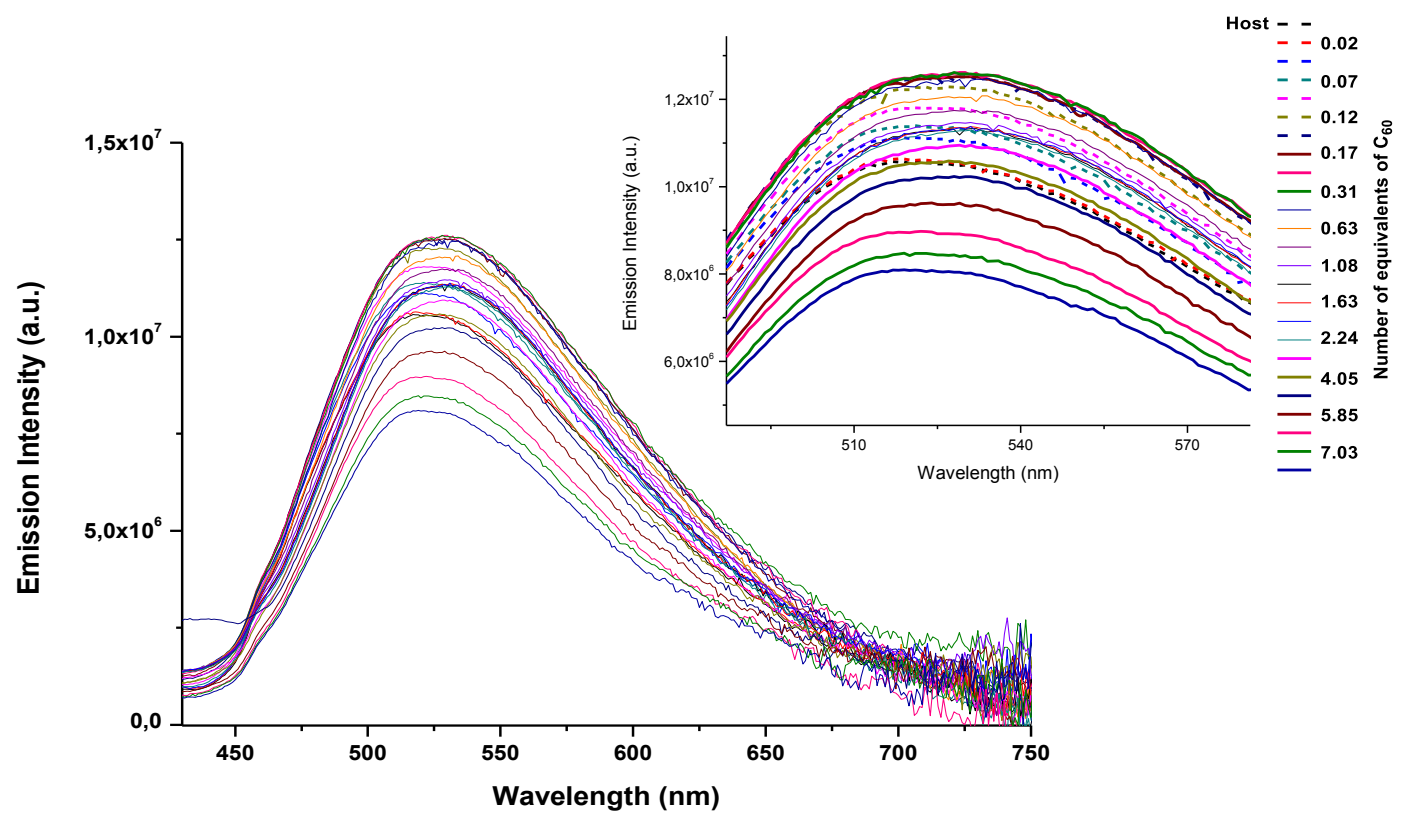

Figure 4.13. Fluorescence spectra during the titration of $3 \mathrm{G}^{\mathrm{tBu}}\left(1.55 \times 10^{-5} \mathrm{M}\right)$ with $\mathrm{C}_{60}\left(1.55 \times 10^{-4} \mathrm{M}\right)$ in toluene at $298 \mathrm{~K}\left(\lambda_{\mathrm{ex}}=403 \mathrm{~nm}\right)$. 


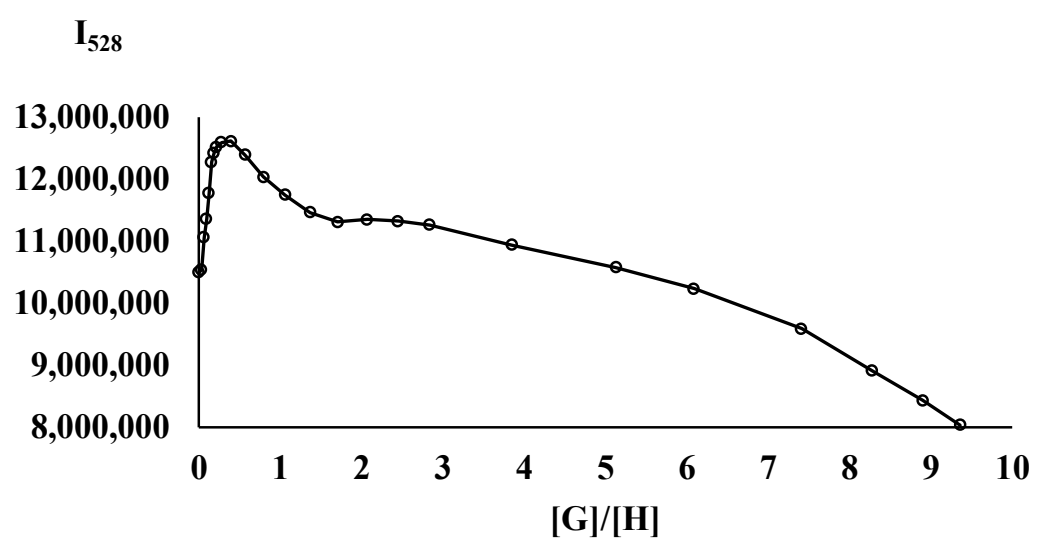

Figure 4.14. Plot of the data values from the titration study of $\mathbf{3 G}^{t \mathbf{B u}}$ with $\mathrm{C}_{60}$. $\mathrm{I}_{528} v s$. equivalents of $[\mathrm{G}] /[\mathrm{H}]$

\section{Isothermal Titration Calorimetry (ITC)}

We then considered that Isothermal Titration Calorimetry (ITC) experiments should help us to obtain additional information on the interaction of complex $\mathbf{3 G}^{\mathbf{t}^{\mathbf{B u}}}$ with $\mathrm{C}_{60}$. ITC is a thermodynamic technique that directly measures the heat released or absorbed upon sequential and incremental addition of a solution of one compound to another in the same solvent (toluene). The work was done in collaboration with the group of Prof. Pau Ballester (ICIQ of Tarragona, Spain). Due to solubility problems, the titrant $\left(\mathbf{3 G}^{\mathbf{t} \mathbf{B u}}\right.$ $\left.+\mathrm{C}_{60}\right)$ and titrand $\left(\mathbf{3 G}^{\mathbf{t} \mathbf{B u}}\right)$ concentrations used in the ITC experiment were suboptimal considering a tentative binding affinity for the $\mathrm{C}_{60} @ \mathbf{3 G}^{\mathbf{t} \mathbf{B u}} 1: 1$ complex in the order of $10^{3} \mathrm{M}^{-1}$, as determined by ${ }^{1} \mathrm{H}$ NMR titrations (vide supra). The ITC experiments were performed by incremental addition of a toluene solution of $\mathrm{C}_{60}(3.8 \mathrm{mM})$ to a toluene solution of $\mathbf{3 G}^{\mathbf{B u}}(0.6 \mathrm{mM})$ located in the cell. The addition of $\mathrm{C}_{60}$ to the solution of $\mathbf{3 G}^{\mathbf{B u}}$ produced the observation of significant evolved heat in the initial injections, indicating an exothermic process. The experimentally obtained binding isotherm was fitted using the "one set of sites" theoretical binding model implemented in the Microcal software. We obtained the best fit for a model that considers the formation of a 1:3 inclusion complex of the type $\mathrm{C}_{60} @\left(\mathbf{3 G}^{t \mathbf{B u}}\right)_{3}$ (Figure 4.15). 


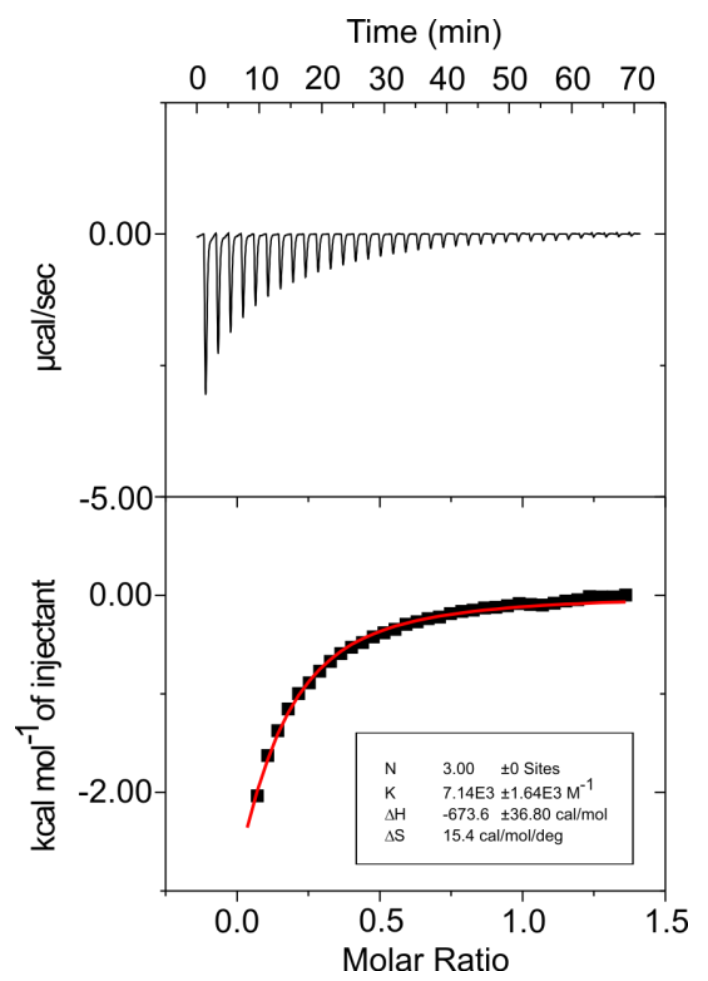

Figure 4.15. ITC experiment of $\mathbf{3 G}^{\mathbf{B u}}(0.6 \mathrm{mM})$ with $\mathrm{C}_{60}(3.8 \mathrm{mM})$ in toluene performed at $298 \mathrm{~K}$. Heat $v s$. time plot for the titration of guest $\mathrm{C}_{60}$ into host $\mathbf{3} \mathbf{G}^{\mathbf{B u}}$ (top). "One set of sites" binding isotherm (red line) fit to the experimental data assuming that the complex of higher stoichiometry formed by the two binding partners is $\mathrm{C}_{60} @\left(\mathbf{3 G}^{\mathbf{B u}}\right)_{3}$ (bottom). This binding model assumes that all binding sites are almost identical. The thermodynamic constants returned in the fitting procedure are shown in the panel inset.

This finding suggested that $\mathrm{C}_{60}$ interacted with $\mathbf{3 G}^{\mathbf{t} \mathbf{B u}}$, in the range of studied concentration, forming complexes of 1:1,2:1 and 3:1 stoichiometry, a result which is in agreement with the ${ }^{1} \mathrm{H}$ NMR titration experiments. The fit of the experimental data to the theoretical model also allowed the determination of an average value for the binding constant of $\mathrm{C}_{60}$ with $\mathbf{3 G}^{t \mathbf{B u}}$ and the average enthalpy of binding $(\Delta \mathrm{H})$ for this process. The free energy $(\Delta \mathrm{G})$ and the entropy $(\Delta \mathrm{S})$ terms were derived from the thermodynamic constants measured experimentally. The average stability constant found was $7.1 \pm 0.7$ x $10^{3} \mathrm{M}^{-1}$, for each individual step leading to $\mathrm{C}_{60} @\left(\mathbf{3 G}^{\mathbf{t} \mathbf{B u}}\right)_{3}$. This value is in agreement with the one obtained using ${ }^{1} \mathrm{H}$ NMR spectroscopy. The average enthalpy per step and per mol of $\mathbf{3 G}^{t \mathbf{B u}}$ in the formation of the $\mathrm{C}_{60} @\left(\mathbf{3 G}^{\mathbf{t} \mathbf{B u}}\right)_{3}$ complex was determined as -0.67 $\pm 0.07 \mathrm{kcal} \mathrm{mol}^{-1}$. An important point is that the entropic term, $\mathrm{T} \Delta \mathrm{S}$, was found to be $4.6 \pm 0.5 \mathrm{kcal} \mathrm{mol}^{-1}$, therefore contributes significantly to the free binding energy that was calculated to be $-5.3 \pm 0.5 \mathrm{kcal} \mathrm{mol}^{-1}$. These results indicate that the binding of $\mathrm{C}_{60}$ with $\mathbf{3 G}^{\mathbf{t} \mathbf{B u}}$ in toluene solution is enthalpically and entropically favored, although 
entropy is the dominant parameter. This result is in clear contradiction with the previous assumptions that the association of single-based corannulene receptors with corannulene should be entropically disfavored, ${ }^{[29]}$ but are in the line of recent findings regarding the positive entropies found when receptors containg more than one corannulene unit are used. ${ }^{[9 \mathrm{a}]}$ Our interpretation of this result is that solvent effects are playing an important role in the process, and for this reason solvation/desolvation processes of the binding process shoud be also take into account.

\section{$\underline{\text { DFT calculations }}$}

In order to gain more insight on the behaviour of our complex in the presence of $\mathrm{C}_{60}$, DFT calculations were performed to determine the structures and binding energies of $\mathbf{3 G}^{\mathbf{B u}}$ with $\mathrm{C}_{60}$. These studies were carried out by Prof. Dmitri Gusev (Wilfrid Laurier University, Canada).

The principal objective of the study was to establish any trends upon the formation of $\mathrm{C}_{60} @\left(\mathbf{3 G}^{\mathbf{t} \mathbf{B u}}\right)_{\mathrm{n}}$ with $\mathrm{n}=1-3$. Along with $\mathbf{3 G}^{\mathbf{t} \mathbf{B u}}$, we calculated a smaller version of this complex possessing all N-CH 3 groups $\mathbf{3 G}^{\mathbf{M e}}$ (Figure 4.16). For the comparison of the energy minimized structures of these complexes, it could be observed that the bulkier complex $\mathbf{3 G}^{\boldsymbol{t}^{\mathbf{B u}}}$ presents a deeper cavity compared to $\mathbf{3} \mathbf{G}^{\mathbf{M e}}$. Therefore, the former was assumed to have the most favourable shape for the association with a fullerene.
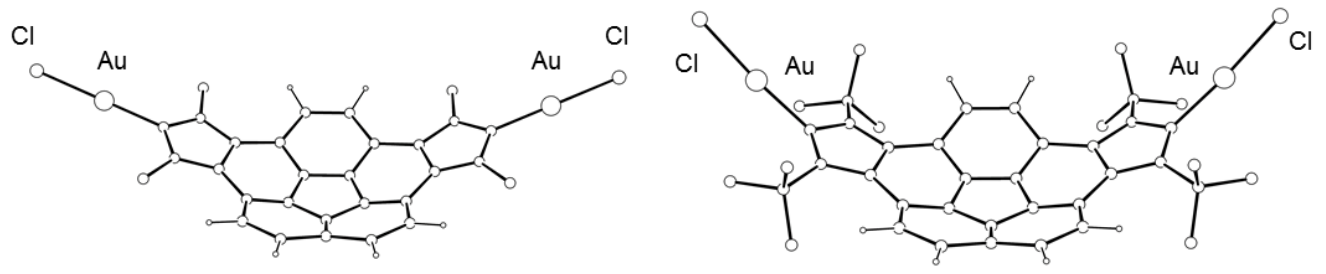

Figure 4.16. Schematic representation of $\mathbf{3 G}^{\mathrm{Me}}$ (left) and $\mathbf{3 G}^{\mathbf{B u}}$ (right)

The computational calculations allowed us to conclude that the formation of the aggregate $\mathrm{C}_{60} @ \mathbf{3 G}^{\prime \mathbf{B u}}$ is more favourable than $\mathrm{C}_{60} @ \mathbf{3 G}^{\mathbf{M e}}$ (see Tables 5.7 and 5.8 in Experimetal Section), a fact that can be related to the more extended and deeper cavity of $\mathbf{3} \mathbf{G}^{\mathbf{t} \mathbf{B u}} v s . \mathbf{3 G}^{\mathbf{M e}}$. This is translated into a better shape-size complementarity of $\mathbf{3} \mathbf{G}^{\mathbf{t} \mathbf{B u}}$ and $\mathrm{C}_{60}$ and thus the stronger dispersion attractive forces in $\mathrm{C}_{60} @ \mathbf{3 G}^{\mathbf{t} \mathbf{B u}}$. 


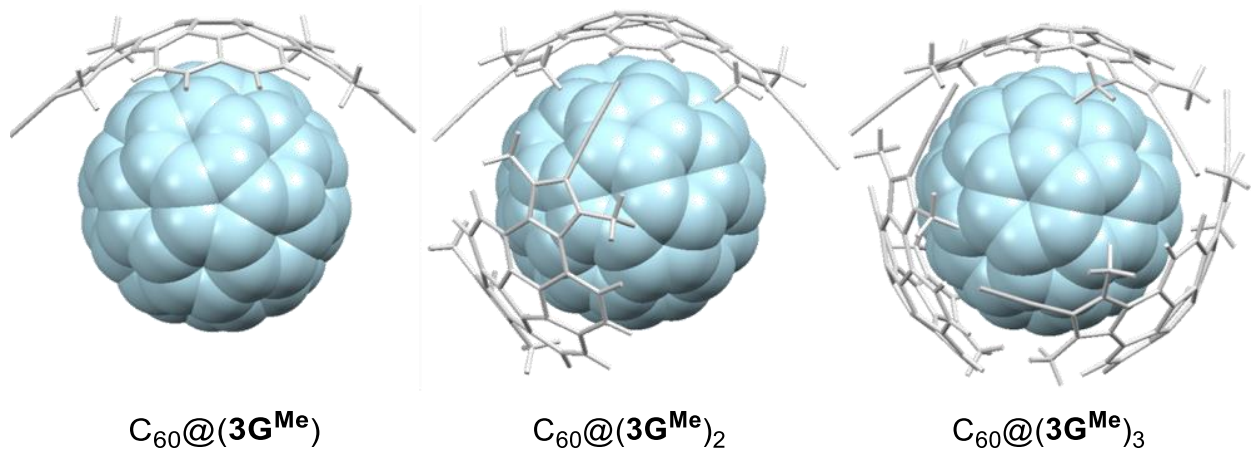

Figure 4.17. Optimized geometries of $\mathrm{C}_{60} @\left(\mathbf{3 G}^{\mathrm{Me}}\right)_{\mathrm{n}}(\mathrm{n}=1-3)$

Unfortunately, the calculations were too costly to allow the optimization of the structure of the aggregate $\mathrm{C}_{60} @\left(\mathbf{3 G}^{\mathbf{B u}}\right)_{3}$, so for the determination of the relative energies associated to the formation of aggregates with different stoichiometries (1:1, 1:2 and 1:3), complex $\mathbf{3 G}^{\mathbf{M e}}$ was used as model. Interestingly, the optimized structure of $\mathrm{C}_{60} @\left(\mathbf{3 G}^{\mathrm{Me}}\right)_{3}$ (Figure 4.17, right) has five of the six chlorides engaged in close $\mathrm{Cl} \cdots \mathrm{H}$ contacts, thus adding further stabilization to the complex with three bis-carbenes forming an interlocked molecular "puzzle" templated on $\mathrm{C}_{60}$.

The free energy of formation of $\mathrm{C}_{60} @\left(\mathbf{3 G}^{\mathrm{Me}}\right)_{3}$ is $-8.2 \mathrm{kcal} / \mathrm{mol}$. As mentioned above, $\mathrm{C}_{60} @\left(\mathbf{3 G}^{\mathbf{B u}}\right)_{3}$ could not be calculated, however, its free formation energy can be estimated by applying the energy difference between $\mathrm{C}_{60} @\left(\mathbf{B G}^{\mathbf{M e}}\right)_{3}$ and $\mathrm{C}_{60} @\left(\mathbf{3 G}^{\mathbf{M e}}\right)_{2}$ $(\Delta \mathrm{G}=-1.7 \mathrm{kcal} / \mathrm{mol})$ toward the energy of formation of $\mathrm{C}_{60} @\left(\mathbf{3 G}^{\mathbf{t} \mathbf{B u}}\right)_{2}(\Delta \mathrm{G}=-7.2$ $\mathrm{kcal} / \mathrm{mol})$. This gives the estimated $\Delta \mathrm{G} \leq-8.9 \mathrm{kcal} / \mathrm{mol}$ for $\mathrm{C}_{60} @\left(\mathbf{3 G}^{\mathbf{t} \mathbf{B u}}\right)_{3}$, suggesting somewhat tighter bonding in the product $v s$. ITC experiment. The entropy change upon the formation of $\mathrm{C}_{60} @\left(\mathbf{3 G}^{\mathbf{t} \mathbf{B u}}\right)_{3}$ should be $\Delta \mathrm{S} \leq 17 \mathrm{cal} \cdot \mathrm{K}^{-1} \cdot \mathrm{mol}^{-1}$, which in full agreement with the ITC experiment.

\subsection{Conclusions}

In this Chapter we described the synthesis and characterization of two bis-imidazolium salt precursors based on a corannulene core.

The deprotonation of one of the corannulene-based bis-azolium salt featuring bulkier substituents allowed the preparation and characterization by NMR of the free corannulene based bis-imidazolylidene carbene ligand, which is stable in solution for a few days.

A series of dimetallic rhodium and gold complexes featuring corannulene-based bis- 
NHC ligands were prepared and fully characterized by standard spectroscopic techniques.

In particular, the tetracarbonyl $\mathrm{Rh}^{(\mathrm{I})}$ complex was used to determine the corannulenebased bis-carbene ligand electron-donating character by means of IR spectroscopy and electrochemical measurements. As a result, it was found that the corannulene-based bisNHC ligand is slightly less donating that its benzoimidazolylidene counterpart.

In addition, di-gold ${ }^{(\mathrm{I})}$ complex was found to be a good receptor for the recognition of fullerene $\mathrm{C}_{60}$ and coronene. In the case of $\mathrm{C}_{60}$, host:guest stoichiometry of $3: 1$ and a high association constants were evidenced by the combination of NMR and ITC titrations. The formation of 3:1 complexes between the di-gold ${ }^{(\mathrm{I})}$ complex and $\mathrm{C}_{60}$ which is favoured by the presence of the two linearly-opposed $\mathrm{NHC}-\mathrm{Au}-\mathrm{Cl}$ fragments, was confirmed by DFT calculations. In contrast, in the case of coronene, a moderate binding affinity and a host:guest stoichiometry of 1:1, were observed. 


\subsection{References}

[1] a) E. Peris, Chem. Commun. 2016, 52, 5777-5787; b) A. J. Boydston, K. A. Williams and C. W. Bielawski, J. Am. Chem. Soc. 2005, 127, 12496-12497.

[2] a) A. Prades, E. Peris and M. Alcarazo, Organometallics 2012, 31, 4623-4626; b) S. Ibanez-Maella, M. Poyatos and E. Peris, Chem. Commun. 2017; c) A. Prades, M. Poyatos, J. A. Mata and E. Peris, Angew. Chem. Int. Ed. 2011, 50, 7666-7669; d) S. Gonell, M. Poyatos and E. Peris, Angew. Chem. Int. Ed. 2013, 52, 70097013; e) C. Segarra, J. Linke, E. Mas-Marza, D. Kuck and E. Peris, Chem. Commun. 2013, 49, 10572-10574; f) S. Gonell, M. Poyatos and E. Peris, Chem. Eur. J. 2014, 20, 9716-9724; g) G. Guisado-Barrios, J. Hiller and E. Peris, Chem. Eur. J. 2013, 19, 10405-10411.

[3] a) T. A. Jin, J. Zhao, N. Asao and Y. Yamamoto, Chem. Eur. J. 2014, 20, 35543576; b) X. Q. Hou, Y. T. Sun, L. Liu, S. T. Wang, R. L. Geng and X. F. Shao, Chin. Chem. Lett. 2016, 27, 1166-1174; c) X. Li, F. Kang and M. Inagaki, Small 2016, 12, 3206-3223.

[4] F. Diederich and M. Gomez-Lopez, Chem. Soc. Rev. 1999, 28, 263-277.

[5] a) D. Canevet, M. Gallego, H. Isla, A. de Juan, E. M. Perez and N. Martin, J. Am. Chem. Soc. 2011, 133, 3184-3190; b) Y. Shoji, K. Tashiro and T. Aida, J. Am. Chem. Soc. 2010, 132, 5928-5929; c) E. Huerta, G. A. Metselaar, A. Fragoso, E. Santos, C. Bo and J. de Mendoza, Angew. Chem. Int. Ed. 2007, 46, 202-205; d) E. Huerta, E. Cequier and J. de Mendoza, Chem. Commun. 2007, 5016-5018.

[6] A. M. Butterfield, B. Gilomen and J. S. Siegel, Org. Process Res. Dev. 2012, 16, 664-676.

[7] a) T. Janowski, P. Pulay, A. A. S. Karunarathna, A. Sygula and S. Saebo, Chem. Phys. Lett. 2011, 512, 155-160; b) P. A. Denis, Chem. Phys. Lett. 2011, 516, 8287; c) Y. Zhao and D. G. Truhlar, Phys. Chem. Chem. Phys. 2008, 10, 2813-2818; d) E. A. Jackson, B. D. Steinberg, M. Bancu, A. Wakamiya and L. T. Scott, J. Am. Chem. Soc. 2007, 129, 484-485.

[8] L. N. Dawe, T. A. AlHujran, H. A. Tran, J. I. Mercer, E. A. Jackson, L. T. Scotc and P. E. Georghiou, Chem. Commun. 2012, 48, 5563-5565.

[9] a) V. H. Le, M. Yanney, M. McGuire, A. Sygula and E. A. Lewis, J. Phys. Chem. $B$ 2014, 118, 11956-11964; b) C. Muck-Lichtenfeld, S. Grimme, L. Kobryn and A. Sygula, Phys. Chem. Chem. Phys. 2010, 12, 7091-7097; c) A. Sygula, F. R. 
Fronczek, R. Sygula, P. W. Rabideau and M. M. Olmstead, J. Am. Chem. Soc. 2007, 129, 3842-3843; d) C. M. Alvarez, L. A. Garcia-Escudero, R. GarciaRodriguez, J. M. Martin-Alvarez, D. Miguel and V. M. Rayon, Dalton Trans. 2014, 43, 15693-15696; e) M. Yanney, F. R. Fronczek and A. Sygula, Angew. Chem. Int. Ed. 2015, 54, 11153-11156; f) M. Yanney and A. Sygula, Tetrahedron Lett. 2013, 54, 2604-2607; g) A. Sygula, M. Yanney, W. P. Henry, F. R. Fronczek, A. V. Zabula and M. A. Petrukhina, Cryst. Growth Des. 2014, 14, 2633-2639.

[10] a) A. S. Filatov, L. T. Scott and M. A. Petrukhina, Cryst. Growth Des. 2010, 10, 4607-4621; b) B. D. Steinberg, E. A. Jackson, A. S. Filatov, A. Wakamiya, M. A. Petrukhina and L. T. Scott, J. Am. Chem. Soc. 2009, 131, 10537-10545.

[11] S. Lampart, L. M. Roch, A. K. Dutta, Y. Wang, R. Warshamanage, A. D. Finke, A. Linden, K. K. Baldridge and J. S. Siegel, Angew. Chem. Int. Ed. 2016, 55, $14648-14652$.

[12] S. Mizyed, P. E. Georghiou, M. Bancu, B. Cuadra, A. K. Rai, P. C. Cheng and L. T. Scott, J. Am. Chem. Soc. 2001, 123, 12770-12774.

[13] a) K. A. Williams and C. W. Bielawski, Chem. Commun. 2010, 46, 5166-5168; b) Y.-T. Wang, M.-T. Chang, G.-H. Lee, S.-M. Peng and C.-W. Chiu, Chem. Commun. 2013, 49, 7258-7260.

[14] H. Clavier and S. P. Nolan, Chem. Commun. 2010, 46, 841-861.

[15] A. C. Hillier, W. J. Sommer, B. S. Yong, J. L. Petersen, L. Cavallo and S. P. Nolan, Organometallics 2003, 22, 4322-4326.

[16] A. Poater, B. Cosenza, A. Correa, S. Giudice, F. Ragone, V. Scarano and L. Cavallo, Eur. J. Inorg. Chem. 2009, 1759-1766.

[17] R. A. Kelly, III, H. Clavier, S. Giudice, N. M. Scott, E. D. Stevens, J. Bordner, I. Samardjiev, C. D. Hoff, L. Cavallo and S. P. Nolan, Organometallics 2008, 27, 202-210.

[18] J. Bouffard, B. K. Keitz, R. Tonner, G. Guisado-Barrios, G. Frenking, R. H. Grubbs and G. Bertrand, Organometallics 2011, 30, 2617-2627.

[19] a) D. Bourissou, O. Guerret, F. P. Gabbai and G. Bertrand, Chem. Rev. 2000, 100, 39-91; b) M. Soleilhavoup and G. Bertrand, Acc. Chem. Res. 2015, 48, 256-266.

[20] a) A. J. Arduengo, R. L. Harlow and M. Kline, J. Am. Chem. Soc. 1991, 113, 361363; b) E. Aldeco-Perez, A. J. Rosenthal, B. Donnadieu, P. Parameswaran, G. Frenking and G. Bertrand, Science 2009, 326, 556-559; c) G. Guisado-Barrios, J. 
Bouffard, B. Donnadieu and G. Bertrand, Angew. Chem. Int. Ed. 2010, 49, 47594762; d) G. Guisado-Barrios, J. Bouffard, B. Donnadieu and G. Bertrand, Organometallics 2011, 30, 6017-6021.

[21] a) F. E. Hahn, L. Wittenbecher, D. Le Van and R. Fröhlich, Angew. Chem. Int. Ed. 2000, 39, 541-544; b) D. M. Khramov, A. J. Boydston and C. W. Bielawski, Angew. Chem. Int. Ed. 2006, 45, 6186-6189; c) J. A. V. Er, A. G. Tennyson, J. W. Kamplain, V. M. Lynch and C. W. Bielawski, Eur. J. Inorg. Chem. 2009, 17291738; d) K. A. Williams and C. W. Bielawski, Chem. Commun. 2010, 46, 51665168; e) F. E. Hahn, L. Wittenbecher, R. Boese and D. Blaser, Chem. Eur. J. 1999, 5, 1931-1935.

[22] a) A. R. Chianese, X. W. Li, M. C. Janzen, J. W. Faller and R. H. Crabtree, Organometallics 2003, 22, 1663-1667; b) D. J. Nelson and S. P. Nolan, Chem. Soc. Rev. 2013, 42, 6723-6753.

[23] A. G. Tennyson, D. M. Khramov, C. D. Varnado, P. T. Creswell, J. W. Kamplain, V. M. Lynch and C. W. Bielawski, Organometallics 2009, 28, 5142-5147.

[24] a) H. Valdes, M. Poyatos and E. Peris, Inorg. Chem. 2015, 54, 3654-3659; b) H. Valdes, M. Poyatos and E. Peris, Organometallics 2014, 33, 394-401.

[25] L. T. Scott, Chem. Soc. Rev. 2015, 44, 6464-6471.

[26] S. Ibanez, M. Poyatos, L. N. Dawe, D. Gusev and E. Peris, Organometallics 2016, $35,2747-2758$.

[27] a) M. J. Pouy, S. A. Delp, J. Uddin, V. M. Ramdeen, N. A. Cochrane, G. C. Fortman, T. B. Gunnoe, T. R. Cundari, M. Sabat and W. H. Myers, Acs Catalysis 2012, 2, 2182-2193; b) M. Katari, M. N. Rao, G. Rajaraman and P. Ghosh, Inorg. Chem. 2012, 51, 5593-5604; c) L. Canovese, F. Visentin, C. Levi and C. Santo, Inorg. Chim. Acta 2012, 391, 141-149; d) E. Alvarado, A. C. Badaj, T. G. Larocque and G. G. Lavoie, Chem. Eur. J. 2012, 18, 12112-12121; e) S. Gaillard, J. Bosson, R. S. Ramon, P. Nun, A. M. Z. Slawin and S. P. Nolan, Chem. Eur. J. 2010, 16, 13729-13740.

[28] a) A. S. K. Hashmi, M. C. Blanco, E. Kurpejovic, W. Frey and J. W. Bats, $A d v$. Synth. Catal. 2006, 348, 709-713; b) N. Huguet, D. Leboeuf and A. M. Echavarren, Chem. Eur. J. 2013, 19, 6581-6585.

[29] A. Sygula, Synlett 2016, 27, 2070-2080. 


\section{Chapter 5}

\section{Experimental Section}





\subsection{Analytical techniques}

\section{Nuclear Magnetic Resonance (NMR)}

${ }^{1} \mathrm{H},{ }^{13} \mathrm{C}\left\{{ }^{1} \mathrm{H}\right\}$ NMR spectra were recorded on the following spectrometers at $298 \mathrm{~K}$ :

- Varian Innova $300 \mathrm{MHz}\left({ }^{1} \mathrm{H} 300 \mathrm{MHz},{ }^{13} \mathrm{C} 75 \mathrm{MHz}\right)$

- Varian Innova $400 \mathrm{MHz}\left({ }^{1} \mathrm{H} 400 \mathrm{MHz},{ }^{13} \mathrm{C} 100 \mathrm{MHz}\right)$

- Varian Innova $500 \mathrm{MHz}\left({ }^{1} \mathrm{H} 500 \mathrm{MHz},{ }^{13} \mathrm{C} 125 \mathrm{MHz}\right)$

- Bruker Avance $200 \mathrm{MHz}\left({ }^{1} \mathrm{H} 200 \mathrm{MHz},{ }^{13} \mathrm{C} 50 \mathrm{MHz}\right)$

- Bruker Avance $300 \mathrm{MHz}\left({ }^{1} \mathrm{H} 300 \mathrm{MHz},{ }^{13} \mathrm{C} 75 \mathrm{MHz}\right)$

- Bruker Avance $400 \mathrm{MHz}\left({ }^{1} \mathrm{H} 400 \mathrm{MHz},{ }^{13} \mathrm{C} 100 \mathrm{MHz}\right)$

Chemical shifts are given in ppm $(\delta)$, referred to the residual peak of the deuterated solvent $\left(\mathrm{CDCl}_{3}, \mathrm{CD}_{2} \mathrm{Cl}_{2}, \mathrm{CD}_{3} \mathrm{CN}, \mathrm{CD}_{3} \mathrm{OD},\left(\mathrm{CD}_{3}\right)_{2} \mathrm{CO}\right.$, toluene- $d_{8}$ and DMSO- $\left.d_{6}\right)$ and reported downfield of $\mathrm{SiMe}_{4}$.

\section{Electrospray Mass Spectra (ESI-MS) and High Resolution Mass Spectroscopy (HR-MS)}

Electrospray Mass Spectra (ESI-MS) were recorded on a Micromass Quatro LC instrument; $\mathrm{CH}_{3} \mathrm{OH}$ or $\mathrm{CH}_{3} \mathrm{CN}$ were used as mobile phase and nitrogen was employed as drying and nebulizing gas. High Resolution Mass Spectra (HR-MS) were recorded on a QTOF I (quadrupole-hexapole-TOF) mass spectrometer with an orthogonal Zspray-electrospray interface (Micromass, Manchester, UK). The drying gas as well as nebulizing gas was nitrogen at a flow of $400 \mathrm{~L} / \mathrm{h}$ and $80 \mathrm{~L} / \mathrm{h}$ respectively. The temperature of the source block was set to $120{ }^{\circ} \mathrm{C}$ and the desolvation temperature to $150^{\circ} \mathrm{C}$. A capillary voltage of $3.5 \mathrm{kV}$ was used in the positive scan mode and the cone voltage was set to $30 \mathrm{~V}$.

\section{Elemental Analysis (EA)}

Elemental analyses were carried out on a EuroEA3000 Eurovector Analyzer.

\section{Gas Chromatography: GC and GC/MS}

GC analyses were obtained on a Shimadzu GC-2010 apparatus equipped with a FID and a Technokroma (TRB-5MS, $30 \mathrm{~m} \times 0.25 \mathrm{~mm}$ x $0.25 \mu \mathrm{m}$ ) column was used. 


\section{Infrared Spectroscopy (IR)}

Infrared spectra (FT-IR) were performed on a JASCO FT/IR-6200 spectrometer with a spectral window of $4000-500 \mathrm{~cm}^{-1}$. The samples were prepared as $\mathrm{KBr}$ disks and in $\mathrm{CH}_{2} \mathrm{Cl}_{2}$ solution.

\section{$\mathrm{UV} / \mathrm{V}$ is Spectroscopy}

UV/Vis absorption spectra were recorded on a Varian Cary 300 BIO spectrophotometer using $\mathrm{CH}_{3} \mathrm{CN}$ or toluene under ambient conditions. Extinction coefficients $(\varepsilon)$ were determined from Beer's law measurements.

\section{Fluorescence Spectroscopy}

Emission spectra were recorded in a modular Horiba FluoroLog®-3 spectrofluorometer employing degassed $\mathrm{CH}_{3} \mathrm{CN}$ or toluene. Quantum yields were determined relative to quinine bisulphate in degassed $1 \mathrm{~N}$ sulfuric acid solution as standard $\left(\phi_{\mathrm{f}}\right)$ with excitation at $290 \mathrm{~nm}$.

\section{Electrochemical Measurements}

Electrochemical studies were carried out by using an Autolab Potentiostat, Model PGSTAT101 using a three-electrode cell. The cell was equipped with platinum working and counter electrodes, as well as a silver wire reference electrode. In all experiments, $\left[\mathrm{NBu}_{4}\right]\left[\mathrm{PF}_{6}\right]\left(0.1 \mathrm{M}\right.$ in dry $\left.\mathrm{CH}_{2} \mathrm{Cl}_{2}\right)$ was used as the supporting electrolyte with analyte concentration of approximately $1 \mathrm{mM}$. Measurements were performed between 50 and $150 \mathrm{mVs}^{-1}$ scan rates. All redox potentials were referenced to the $\mathrm{Fc}^{+} / \mathrm{Fc}$ couple as internal standard with $E_{1 / 2}\left(\mathrm{Fc} / \mathrm{Fc}^{+}\right)$vs. $\mathrm{SCE}=+0.44 \mathrm{~V}$.

\section{X-Ray Diffraction}

Diffraction data were collected on a Agilent SuperNova diffractometer equipped with an Altas CCD detector using $\mathrm{Cu} \mathrm{K} \alpha$ radiation $(\lambda=1.54184 \AA)$. Single crystal was mounted on a MicroMount polymer tip (MiteGen) in a random orientation. The structures were solved by direct methods in SHELXS-97 ${ }^{[1]}$ and refined by the fullmatrix method based on $\mathrm{F}^{2}$ with the program SHELXL-97 using the OLEX software package. ${ }^{[1-2]}$ Key details of the crystals and structures refinement data are summarized in the following tables. Table 5.10-14. Further crystallographic data may be found in the corresponding CIF file which was deposited at the Cambridge Crystallographic Data Centre CCDC, Cambridge, UK. 


\section{ITC}

Isothermal titration calorimetry (ITC) experiments were carried out by using Microcal ITC Data Analysis Module.

\subsection{Synthesis and characterization}

All manipulations were carried out by using standard Schlenk techniques under nitrogen atmosphere unless otherwise stated. Anhydrous solvents were dried using a solvent purification system (SPS M BRAUN) or purchased from Aldrich and degassed prior to use by purging with dry nitrogen and kept over molecular sieves. All other reagents were used as received from commercial suppliers (1,3,5-tris(4-bromophenyl)benzene, 1,3-bis(2,6-diisopropylphenyl)imidazolium chloride (IPr.HCl), 1-phenylimidazole, coronene, fullerene $\left(\mathrm{C}_{60}\right), \mathrm{NiCp}_{2}, \mathrm{Ag}_{2} \mathrm{O}, \mathrm{CuI}$ and $[\mathrm{RhCl}(\mathrm{COD})]_{2}$. 1,3,5-tris(4ethynylphenyl)benzene, ${ }^{[3]} 1,3$-dimesityltriazine, ${ }^{[4]}[\operatorname{IrCl}(\mathrm{COD})]_{2}{ }^{[5]}$ and $\left[\mathrm{AuCl}\left(\mathrm{SMe}_{2}\right)\right]^{[6]}$ was obtained as described in the literature. 1,2,5,6-tetrabromocorannulene has been provided by Jay S. Siegel research group. ${ }^{[7]}$

\subsubsection{Synthesis and characterization of azolium and triazolium salts:}

\section{Chapter 2 and 3}

\section{Synthesis of A}

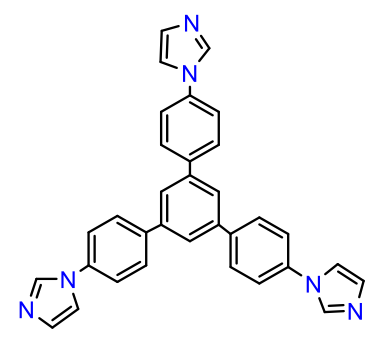

A round bottomed flask was loaded with 1,3,5-tris(4bromophenylbenzene) (1 g, $1.84 \mathrm{mmol}), \mathrm{K}_{2} \mathrm{CO}_{3}(1.25 \mathrm{~g}, 9.05$ mmol), imidazole $(0.75 \mathrm{~g}, 11.02 \mathrm{mmol})$ and $\mathrm{CuSO}_{4}(5 \mathrm{mg}, 0.03$ mmol). DMSO ( $5 \mathrm{~mL}$ ) was added and the reaction mixture was heated to $185{ }^{\circ} \mathrm{C}$ for 2 days. Then the solvent was removed by distillation. The crude mixture was redissolved in methylene chloride and washed with water. The resulting organic solution was dried with $\mathrm{MgSO}_{4}$, and the solvent was removed under vacuum to yield a yellow solid, $0.60 \mathrm{~g}(65 \%) .{ }^{1} \mathrm{H}$ NMR (300 MHz, $\left.\mathrm{CDCl}_{3}\right): \delta(\mathrm{ppm}) 7.94(\mathrm{~s}, 3 \mathrm{H}, \mathrm{NCHN}), 7.82\left(\mathrm{~m}, 9 \mathrm{H}, \mathrm{CH}_{\text {Imid }}, \mathrm{CH}_{\mathrm{Ar}}\right.$ ), $7.55\left(\mathrm{~d}, J=6.6 \mathrm{~Hz}, 6 \mathrm{H}, \mathrm{C} H_{\mathrm{Ar}}\right), 7.36\left(\mathrm{~s}, 3 \mathrm{H}, \mathrm{C} H_{\mathrm{Ar}}\right), 7.26\left(\mathrm{~s}, 3 \mathrm{H}, \mathrm{C} H_{\text {Imid }}\right) .{ }^{13} \mathrm{C}\left\{{ }^{1} \mathrm{H}\right\} \mathrm{NMR}$ (75 MHz, $\left.\mathrm{CDCl}_{3}\right): \delta(\mathrm{ppm}) 141.6\left(C_{\mathrm{Ar}}\right), 140.1\left(C_{\mathrm{Ar}}\right), 137.1\left(C_{\mathrm{Ar}}\right), 135.7\left(C_{\mathrm{Imid}}\right), 130.8$ $\left(C_{\text {Imid }}\right), 128.9\left(C_{\mathrm{Ar}}\right), 125.4\left(C_{\text {Imid }}\right), 122.0\left(C_{\mathrm{Ar}}\right), 118.3\left(C_{\mathrm{Ar}}\right)$. Electrospray MS $(20 \mathrm{~V}, \mathrm{~m} / z)$ : $253.3[\mathrm{M}+2 \mathrm{H}]^{2+}$. Elemental analysis calcd $(\%)$ for $\mathrm{C}_{33} \mathrm{H}_{24} \mathrm{~N}_{6} \cdot 2 \mathrm{H}_{2} \mathrm{O}: \mathrm{C}, 73.3 ; \mathrm{H}, 5.2 ; \mathrm{N}$, 
15.5; found C 73.3; H 3.9; N 15.4. Melting point: $148^{\circ} \mathrm{C}$. Decomposition temperature: $243{ }^{\circ} \mathrm{C}$.

\section{Synthesis of $\left[\mathrm{H}_{3} \mathrm{~B}^{\mathrm{Et}}\right]\left(\mathrm{BF}_{4}\right)_{3}$}

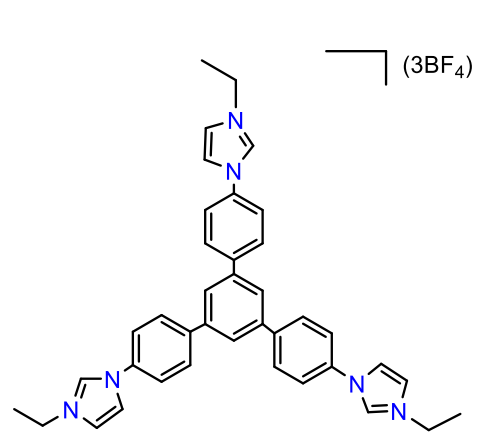

Triethyloxonium tetrafluoroborate $(0.844 \mathrm{~g}, 4.44 \mathrm{mmol})$ was added to a Schlenk tube containing a solution of 1,3,5-tris(4-imidazolylphenylbenzene) (A) $(0.5 \mathrm{~g}, 0.99$ mmol) in dry methylene chloride $(30 \mathrm{~mL})$. Instantaneously, a white precipitate crashed out. The solid was filtered, washed with hexane and $\mathrm{MeOH}$ to yield $0.462 \mathrm{~g}$ of a white powder $(55 \%) .{ }^{1} \mathrm{H}$ NMR $(300 \mathrm{MHz}$,

DMSO- $\left.d_{6}\right): \delta(\mathrm{ppm}) 9.86(\mathrm{~s}, 3 \mathrm{H}, \mathrm{NCHN}), 8.41\left(\mathrm{~d}, J=8.4 \mathrm{~Hz}, 3 \mathrm{H}, \mathrm{C} H_{\mathrm{Ar}}\right), 8.29-8.15(\mathrm{~m}$, 9H, CH $\left.H_{\text {Imid }}, \mathrm{CH}_{\mathrm{Ar}}\right), 8.10\left(\mathrm{~d}, J=8.1 \mathrm{~Hz}, 3 \mathrm{H}, \mathrm{C} H_{\text {Imid }}\right), 7.96\left(\mathrm{~d}, J=8.4 \mathrm{~Hz}, 6 \mathrm{H}, \mathrm{CH}_{\mathrm{Ar}}\right)$, 4.33 (q, $J=7.3 \mathrm{~Hz}, 6 \mathrm{H}, \mathrm{CH}$ ), 1.55 (t, $\left.J=7.3 \mathrm{~Hz}, 9 \mathrm{H}, \mathrm{CH}_{3}\right) .{ }^{13} \mathrm{C}\left\{{ }^{1} \mathrm{H}\right\} \mathrm{NMR}(75 \mathrm{MHz}$, DMSO- $\left.d_{6}\right): \delta(\mathrm{ppm}) 140.9\left(C_{\mathrm{Ar}}\right), 140.2\left(C_{\mathrm{Ar}}\right), 135.1(\mathrm{NCHN}), 134.4\left(C_{\mathrm{Ar}}\right), 129.0\left(C_{\mathrm{Ar}}\right)$, $125.4\left(C_{\mathrm{Ar}}\right), 123.0\left(C_{\text {Imid }}\right), 122.2\left(C_{\mathrm{Ar}}\right), 121.1\left(C_{\text {Imid }}\right), 44.8\left(\mathrm{CH}_{2}\right), 14.8\left(\mathrm{CH}_{3}\right)$. Electrospray MS $(20 \mathrm{~V}, \mathrm{~m} / \mathrm{z}): 196.9[\mathrm{M}]^{3+}, 339.3\left[\mathrm{M}+\mathrm{BF}_{4}\right]^{2+}$. Elemental analysis calcd (\%) for $\mathrm{C}_{39} \mathrm{H}_{39} \mathrm{~N}_{6} \mathrm{~B}_{3} \mathrm{~F}_{12} 2 \mathrm{H}_{2} \mathrm{O}: \mathrm{C}, 52.7 ; \mathrm{H}, 4.9 ; \mathrm{N}, 9.5$; found $\mathrm{C}, 52.8 ; \mathrm{H}, 5.1 ; \mathrm{N}, 9.5$. Decomposition temperature: $174{ }^{\circ} \mathrm{C}$

\section{Synthesis of $\left[\mathrm{H}_{3} \mathrm{~B}^{\mathrm{Et}}\right](\mathrm{Br})_{3}$}

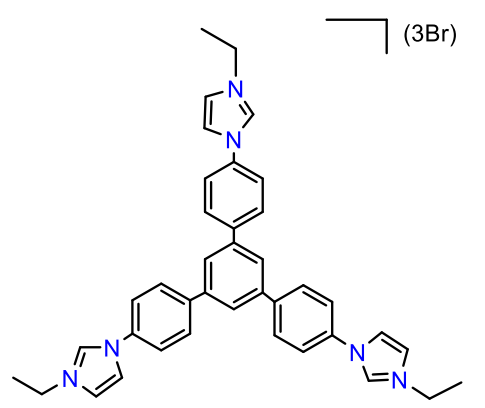

A sample of compound $\mathbf{A}(0.316 \mathrm{~g}, 0.63 \mathrm{mmol})$ and ethyl bromide (0.409 g, $3.76 \mathrm{mmol})$ were dissolved in DMF (10 $\mathrm{mL})$ and the solution was heated to $100{ }^{\circ} \mathrm{C}$ for $48 \mathrm{~h}$. A white solid precipitated over this period. After cooling of the reaction mixture to ambient temperature, the white precipitate was filtered off, washed with diethyl ether and dried in vacuo to give the salt $\left[\mathbf{H}_{3} \mathbf{B}^{\mathrm{Et}}\right](\mathbf{B r})_{3}$. Yield: $0.344 \mathrm{~g}(66 \%) .{ }^{1} \mathrm{H}$ NMR (400 MHz, DMSO- $\left.d_{6}\right): \delta(\mathrm{ppm}) 10.05(\mathrm{~s}, 3 \mathrm{H}, \mathrm{NCHN}), 8.46$ (s, 3H, $\left.\mathrm{CH}_{\text {Imid }}\right), 8.29(\mathrm{~d}, J=8.7 \mathrm{~Hz}, 6 \mathrm{H}$, $\left.\mathrm{CH}_{\text {Ar }}\right), 8.17$ (s, 3H, CH $\left.H_{\text {Ar }}\right), 8.14$ (s, 3H, $\left.\mathrm{CH}_{\text {Imid }}\right), 8.00$ (d, $\left.J=8.7 \mathrm{~Hz}, 6 \mathrm{H}, \mathrm{CH}_{\mathrm{Ar}}\right), 4.35$ (q, $\left.J=7.3 \mathrm{~Hz}, 6 \mathrm{H}, \mathrm{CH}_{2}\right), 1.55\left(\mathrm{t}, J=7.3 \mathrm{~Hz}, 9 \mathrm{H}, \mathrm{CH}_{3}\right) .{ }^{13} \mathrm{C}\left\{{ }^{1} \mathrm{H}\right\}$ NMR (100 MHz, DMSO$\left.\mathrm{d}_{6}\right): \delta(\mathrm{ppm}) 140.7\left(C_{\mathrm{Ar}}\right), 140.1\left(C_{\mathrm{Ar}}\right), 135.1(\mathrm{NCHN}), 134.3\left(C_{\mathrm{Ar}}\right), 128.9\left(C_{\mathrm{Ar}}\right), 125.3$ $\left(C_{\mathrm{Ar}}\right), 123.0\left(C_{\text {Imid }}\right), 122.1\left(C_{\mathrm{Ar}}\right), 121.0\left(C_{\text {Imid }}\right), 44.8\left(\mathrm{CH}_{2}\right), 14.8\left(\mathrm{CH}_{3}\right)$. HR-MS $(\mathrm{m} / \mathrm{z})$ : 197.1073 [M] $]^{3+}$. Elemental analysis calcd (\%) for $\mathrm{C}_{39} \mathrm{H}_{39} \mathrm{~N}_{6} \mathrm{Br}_{3} \cdot \mathrm{H}_{2} \mathrm{O}: \mathrm{C}, 55.1 ; \mathrm{H}, 4.9 ; \mathrm{N}$, 9.9; found $\mathrm{C}, 55.1 ; \mathrm{H}, 5.3 ; \mathrm{N}, 9.9$. 


\section{Synthesis of $\left[\mathrm{H}_{3} \mathrm{~B}^{\mathrm{Et}}\right]\left(\mathrm{PF}_{6}\right)_{3}$}

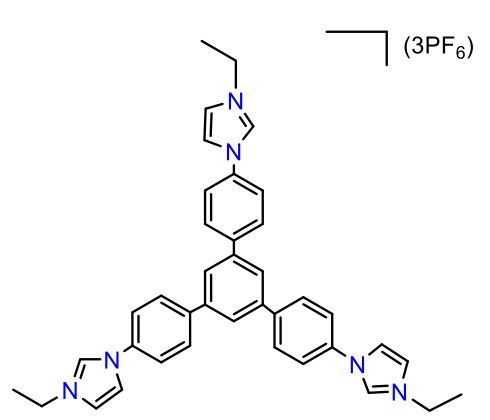

A methanolic solution of $\mathrm{NH}_{4} \mathrm{PF}_{6}(0.270 \mathrm{~g}, 1.66 \mathrm{mmol}$ in $5 \mathrm{~mL}$ of $\mathrm{MeOH}$ ) was added to a methanolic solution of $\left.\left[\mathbf{H}_{3} \mathbf{B}^{\mathrm{Et}}\right] \mathbf{( B r}\right)_{3}(0.344 \mathrm{~g}, 0.41 \mathrm{mmol}$ in $10 \mathrm{~mL}$ of $\mathrm{MeOH})$. The hexafluorophosphate salt $\left[\mathbf{H}_{3} \mathbf{B}^{\mathrm{Et}}\right]\left(\mathbf{P F}_{6}\right)_{3}$ precipitated as white solid. The solid was collected by filtration, washed with cold methanol and diethyl ether and dried in vacuo. Yield: $0.334 \mathrm{~g}(79 \%) .{ }^{1} \mathrm{H}$ NMR (400 MHz, DMSO-d $)$ : $\delta$ (ppm) 9.88 (s, 3H, $\mathrm{NCHN}), 8.42\left(\mathrm{~s}, 3 \mathrm{H}, \mathrm{C} H_{\text {Imid }}\right), 8.29\left(\mathrm{~d}, J=8.6 \mathrm{~Hz}, 6 \mathrm{H}, \mathrm{C} H_{\text {Ar }}\right), 8.18\left(\mathrm{~s}, 3 \mathrm{H}, \mathrm{C} H_{\text {Ar }}\right), 8.10$ (s, 3H, CH Imid), 7.96 (d, $\left.J=8.6 \mathrm{~Hz}, 6 \mathrm{H}, \mathrm{C} H_{\text {Ar }}\right), 4.33$ (q, $\left.J=7.3 \mathrm{~Hz}, 6 \mathrm{H}, \mathrm{CH}_{2}\right), 1.56$ (t, $J$ $\left.=7.3 \mathrm{~Hz}, 9 \mathrm{H}, \mathrm{CH}_{3}\right) \cdot{ }^{13} \mathrm{C}\left\{{ }^{1} \mathrm{H}\right\} \mathrm{NMR}\left(100 \mathrm{MHz}, \mathrm{DMSO}-\mathrm{d}_{6}\right): \delta(\mathrm{ppm}) 140.8\left(C_{\mathrm{Ar}}\right), 140.1$ $\left(C_{\mathrm{Ar}}\right), 135.1(\mathrm{NCHN}), 134.4\left(C_{\mathrm{Ar}}\right), 128.9\left(C_{\mathrm{Ar}}\right), 125.3\left(C_{\mathrm{Ar}}\right), 123.0\left(C_{\mathrm{Imid}}\right), 122.1\left(C_{\mathrm{Ar}}\right)$, 121.0 ( $\left.C_{\text {Imid }}\right), 44.8\left(\mathrm{CH}_{2}\right), 14.7\left(\mathrm{CH}_{3}\right)$. HR-MS $(\mathrm{m} / \mathrm{z}): 197.1073[\mathrm{M}]^{3+}$.

\section{Synthesis of $\left[\mathrm{H}_{3} \mathrm{~B}^{\mathrm{Me}}\right]\left(\mathrm{CF}_{3} \mathrm{SO}_{3}\right)_{3}$}

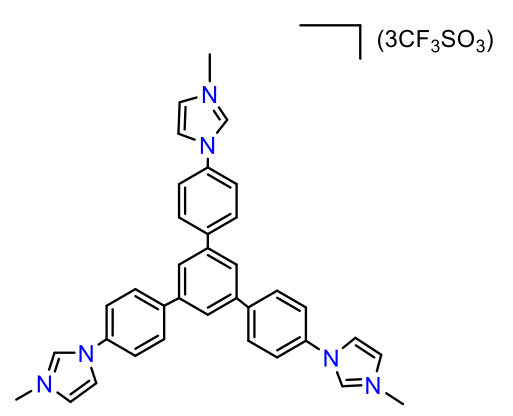

Methyl trifluoromethanesulfonate $(143 \mu \mathrm{L} 1.31 \mathrm{mmol})$ was added to a Schlenk containing a solution of $1,3,5$ tris(4-imidazolylphenylbenzene) (A) $(0.2 \mathrm{~g}, 0.40 \mathrm{mmol})$ in 1,2-dichloroethane $(10 \mathrm{~mL})$. The solution was heated at $100^{\circ} \mathrm{C}$ overnight. An oily precipitate was obtained after evaporating the solvent. $\mathrm{MeOH}$ was added to dissolve the oily crude, and the addition of hexane yielded a light brown solid, $0.264 \mathrm{~g}$ (72 \%). ${ }^{1} \mathrm{H}$ NMR (300 MHz, CD $\left.{ }_{3} \mathrm{OD}\right): \delta(\mathrm{ppm}) 9.52(\mathrm{~s}, 3 \mathrm{H}, \mathrm{NCHN}), 8.12-8.05(\mathrm{~m}$, $\left.12 \mathrm{H}, \mathrm{CH}_{\text {Imid }}, \mathrm{CH}_{\text {Ar }}\right), 7.88-7.81\left(\mathrm{~m}, 9 \mathrm{H}, \mathrm{CH}_{\text {Imid }}, \mathrm{CH}_{\mathrm{Ar}}\right), 4.08(\mathrm{~s}, 9 \mathrm{H}, \mathrm{CH}) .{ }^{13} \mathrm{C}\left\{{ }^{1} \mathrm{H}\right\} \mathrm{NMR}$ (75 MHz, $\left.\mathrm{CD}_{3} \mathrm{CN}\right): \delta(\mathrm{ppm}) 142.8\left(C_{\mathrm{Ar}}\right), 141.6\left(C_{\mathrm{Ar}}\right), 136.3(\mathrm{NCHN}), 135.4\left(C_{\mathrm{Ar}}\right), 130.1$ $\left(C_{\mathrm{Ar}}\right), 126.8\left(C_{\mathrm{Ar}}\right), 125.3\left(C_{\text {Imid }}\right), 123.6\left(C_{\mathrm{Ar}}\right), 122.4\left(C_{\text {Imid }}\right), 37.2\left(C_{3}\right)$. Electrospray MS $(20 \mathrm{~V}, m / z): 183.2[\mathrm{M}]^{3+}$. Elemental analysis calcd (\%) for $\mathrm{C}_{39} \mathrm{H}_{33} \mathrm{~N}_{6} \mathrm{~S}_{3} \mathrm{O}_{9} \mathrm{~F}_{9} \cdot \mathrm{H}_{2} \mathrm{O}$ : C, 46.2; H, 3.5; N, 8.3; found C, 46.2; H, 4.5; N, 7.9. Decomposition temperature: 184 ${ }^{\circ} \mathrm{C}$. 


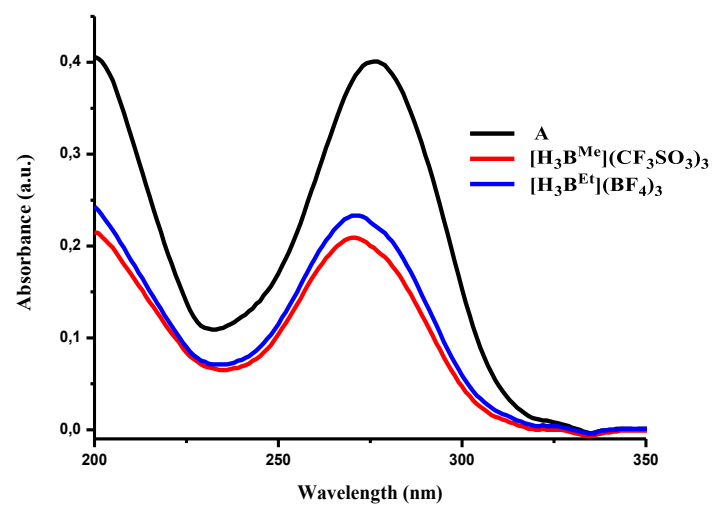

Figure 5.1. UV spectra of compounds $A,\left[\mathbf{H}_{3} \mathbf{B}^{\mathrm{Me}}\right]\left(\mathrm{CF}_{3} \mathrm{SO}_{3}\right)_{3}$ and $\left[\mathrm{H}_{3} \mathbf{B}^{\mathrm{Et}}\right]\left(\mathrm{BF}_{4}\right)_{3}$ recorded in $\mathrm{MeCN}$

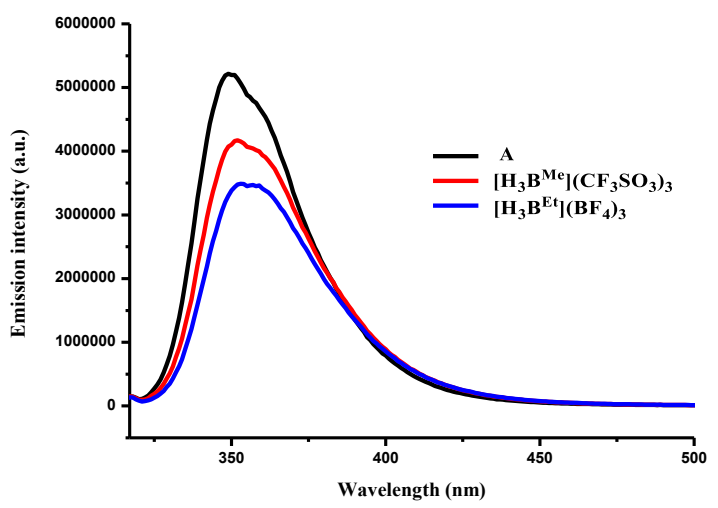

Figure 5.2. Emission spectra of compounds $\mathbf{A},\left[\mathbf{H}_{3} \mathbf{B}^{\mathrm{Me}}\right]\left(\mathbf{C F}_{3} \mathbf{S O}_{3}\right)_{3}$ and $\left[\mathbf{H}_{3} \mathbf{B}^{\mathrm{Et}}\right]\left(\mathbf{B F}_{4}\right)_{3}$ at $290 \mathrm{~nm}$ in $\mathrm{MeCN}$

\section{Synthesis of $\left[\mathrm{H}_{3} \mathrm{C}^{\mathrm{Mes}}\right]\left(\mathrm{PF}_{6}\right)_{3}$}

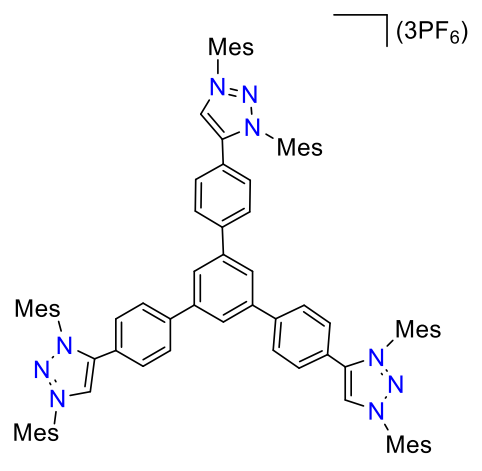

In a Schlenk tube, a mixture of wrapped with aluminum foil containing 1,3,5-tris-(4-ethynylphenyl)benzene (270 $\mathrm{mg}, \quad 0.71 \mathrm{mmol})$, 1,3-dimesityltriazene $(1.50 \mathrm{~g}, 4.10$ mmol) and $\mathrm{KPF}_{6}(990 \mathrm{mg}, 5.38 \mathrm{mmol})$ in $\mathrm{CH}_{2} \mathrm{Cl}_{2}$ was cooled down to $-78{ }^{\circ} \mathrm{C}$ and stirred during $30 \mathrm{~min}$. Then ${ }^{t} \mathrm{BuOCl}$ (486 mg, $0.53 \mathrm{mmol}$ ) was added dropwise over the period of one hour at $-78{ }^{\circ} \mathrm{C}$ and the reaction mixture was stirred at $-78{ }^{\circ} \mathrm{C}$ during 6 hours. The reaction was allowed to slowly warm up and stirred at room temperature overnight. The resulting solution was filtrated, and the filtrate was evaporated. The resulting white solid was washed with diethyl ether and $\mathrm{MeOH}$ (yield: 1.1 g. 93\%). ${ }^{1} \mathrm{H} \mathrm{NMR}\left(300 \mathrm{MHz}, \mathrm{CDCl}_{3}\right.$ ): $\delta$ (ppm) 9.08 (s, 3H, $\mathrm{NCHN}$ ), $7.77\left(\mathrm{~m}, 9 \mathrm{H}, \mathrm{CH} H_{\mathrm{Ar}}\right), 7.60\left(\mathrm{~m}, 6 \mathrm{H}, \mathrm{C} H_{\mathrm{Ar}}\right), 7.14$ (d, 12H, J=6 Hz CHAr), 2.43 (bs, 18H, 
$\mathrm{CH}_{3}$ ), 2.22 (bs, 18H, $\mathrm{CH}_{3}$ ), 2.06 (bs, $\left.18 \mathrm{H}, \mathrm{CH}_{3}\right) .{ }^{13} \mathrm{C}\left\{{ }^{1} \mathrm{H}\right\} \mathrm{NMR}\left(75 \mathrm{MHz}, \mathrm{CDCl}_{3}\right): \delta$ $(\mathrm{ppm}) 144.7\left(C_{\mathrm{Ar}}\right), 144.0\left(C_{\mathrm{Ar}}\right), 143.9\left(C_{\mathrm{Ar}}\right), 143.1\left(C_{\mathrm{Ar}}\right), 140.7\left(C_{\mathrm{Ar}}\right), 134.4\left(C_{\mathrm{Ar}}\right), 134.1$ $\left(C_{\mathrm{Ar}}\right), 131.3(\mathrm{NCHN}), 130.8\left(C_{\mathrm{Ar}}\right), 130.2\left(C_{\mathrm{Ar}}\right), 128.7\left(C_{\mathrm{Ar}}\right), 126.0\left(C_{\mathrm{Ar}}\right), 120.7\left(C_{\mathrm{Ar}}\right)$, $21.5\left(\mathrm{CH}_{3}\right), 21.4\left(\mathrm{CH}_{3}\right), 17.5\left(\mathrm{CH}_{3}\right), 17.3\left(\mathrm{CH}_{3}\right)$. Electrospray MS $(20 \mathrm{~V}, \mathrm{~m} / \mathrm{z}): 406.6$ $[\mathrm{M}]^{3+}, 682.5\left[\mathrm{MPF}_{6}\right]^{2+}$. Elemental analysis calcd $(\%)$ for $\mathrm{C}_{84} \mathrm{H}_{84} \mathrm{~N}_{9} \mathrm{P}_{3} \mathrm{~F}_{18} \cdot 3 \mathrm{CH}_{2} \mathrm{Cl}_{2}: \mathrm{C}$, $54.7 ; \mathrm{H}, 4.7 ; \mathrm{N}, 6.6$; found $\mathrm{C}, 54.3 ; \mathrm{H}, 5.0 ; \mathrm{N}, 7.2$.

\section{Synthesis of $\left[\mathrm{HD}^{\mathrm{Et}}\right]\left(\mathrm{BF}_{4}\right)$}

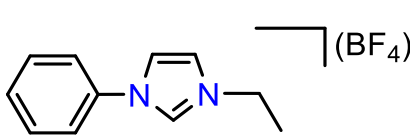

Triethyloxonium tetrafluoroborate was added $(0.450 \mathrm{~g}, 2.37$ mmol) to a Schlenk tube containing a solution of 1phenylimidazole $(200 \mu \mathrm{L}, 1.60 \mathrm{mmol})$ in dry methylene chloride $(10 \mathrm{~mL})$ at room temperature. After 30 minutes, the solvent was removed affording an oil that was broken by hexane addition to yield $0.332 \mathrm{~g}$ of a white powder (81\%). ${ }^{1} \mathrm{H}$ NMR (300 MHz, CD $\left.{ }_{3} \mathrm{CN}\right): \delta(\mathrm{ppm}) 8.95$ (s, $\left.1 \mathrm{H}, \mathrm{NCHN}\right), 7.78$ (t, J=1.8 Hz, 1H, $\left.\mathrm{C} H_{\text {Imid }}\right), 7.69-7.56\left(\mathrm{~m}, 6 \mathrm{H}, \mathrm{CH}_{\text {Imid }}, \mathrm{CH}_{\mathrm{Ar}}\right), 4.31$ (q, $\left.J=7.3 \mathrm{~Hz}, 2 \mathrm{H}, \mathrm{C} H_{2}\right), 1.55$ (t, $J$ $\left.=7.3 \mathrm{~Hz}, 3 \mathrm{H}, \mathrm{CH}_{3}\right) .{ }^{13} \mathrm{C}\left\{{ }^{1} \mathrm{H}\right\} \operatorname{NMR}\left(75 \mathrm{MHz}, \mathrm{CD}_{3} \mathrm{CN}\right): \delta(\mathrm{ppm}) 135.8\left(C_{\mathrm{Ar}}\right), 135.3$ $\left(C_{\mathrm{Ar}}\right), 131.2\left(C_{\mathrm{Ar}}\right), 131.1\left(C_{\mathrm{Ar}}\right), 123.8(\mathrm{NCHN}), 123.3\left(C_{\mathrm{Imid}}\right), 122.6\left(C_{\text {Imid }}\right), 46.3\left(C_{2}\right)$, $15.2\left(\mathrm{CH}_{3}\right)$. Electrospray MS (20 V, $\left.\mathrm{m} / \mathrm{z}\right): 173.0[\mathrm{M}]^{+}$. Elemental analysis calcd $(\%)$ for $\mathrm{C}_{11} \mathrm{H}_{13} \mathrm{~N}_{2} \mathrm{BF}_{4}: \mathrm{C}, 50.8 ; \mathrm{H}, 5.0 ; \mathrm{N}, 10.8$; found $\mathrm{C}, 50.0 ; \mathrm{H}, 4.7 ; \mathrm{N}, 10.6$.

\subsubsection{Synthesis and characterization of azolium salts: Chapter 4}

\section{Synthesis of $\mathbf{F}$}

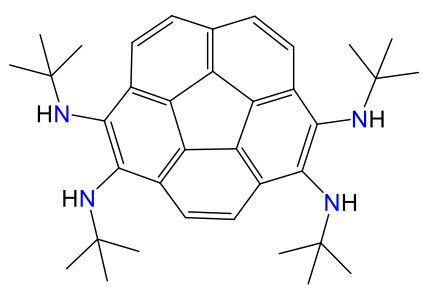

To a flame dried Schlenk (A) containing a suspension of 1,2,5,6-tetrabromocorannulene $(300 \mathrm{mg}, 0.53 \mathrm{mmol})$ in dry toluene $(20 \mathrm{~mL})$ was added $\mathrm{NaO}^{t} \mathrm{Bu}(2 \mathrm{M}$ in $\mathrm{THF}, 1.27 \mathrm{~mL}$, $2.54 \mathrm{mmol})$. In parallel, to a flame dried Schlenk (B), containing a suspension of $\left[\mathrm{Pd}(\mathrm{OAc})_{2}\right](8.36 \mathrm{mg}, 0.037$

mmol), IPr. $\mathrm{HCl}(31.75 \mathrm{mg}, 0.074 \mathrm{mmol})$ in dry toluene $(5 \mathrm{~mL})$ was added $\mathrm{NaO}^{t} \mathrm{Bu}(2 \mathrm{M}$ in THF, $57 \mu \mathrm{L}, 0.11 \mathrm{mmol}$ ). Both Schlenk tubes were stirred for $15 \mathrm{~min}$ at room temperature. Then, the solution from Schlenk (B) was transferred to Schlenk (A) via oven-dried cannula. Finally, tert-butyl amine $(280 \mu \mathrm{L}, 2.6 \mathrm{mmol})$ was added and the resulting mixture was refluxed overnight. The reaction mixture was allowed to cool down to room temperature and filtered over Celite. The solvent was evaporated under reduced pressure, yielding the desired product as an orange solid. Yield: $275 \mathrm{mg}$ (97\%). 
${ }^{1} \mathrm{H}$ NMR (500 MHz, $\left.\mathrm{CDCl}_{3}\right): \delta(\mathrm{ppm}) 7.84\left(\mathrm{~d}, J=8.8 \mathrm{~Hz}, 2 \mathrm{H}, \mathrm{CH} H_{\mathrm{Ar}}\right), 7.82(\mathrm{~s}, 2 \mathrm{H}$, $\left.\mathrm{CH}_{\mathrm{Ar}}\right), 7.63\left(\mathrm{~d}, J=8.8 \mathrm{~Hz}, 2 \mathrm{H}, \mathrm{C} H_{\mathrm{Ar}}\right), 4.51$ (s, 2H, NH), $4.22(\mathrm{~s}, 2 \mathrm{H}, \mathrm{N} H), 1.31$ (m, $36 \mathrm{H}, \mathrm{C}(\mathrm{CH}) 3) .{ }^{13} \mathrm{C}\left\{{ }^{1} \mathrm{H}\right\} \mathrm{NMR}\left(100.8 \mathrm{MHz}, \mathrm{CDCl}_{3}\right): \delta(\mathrm{ppm}) 137.4\left(C_{\mathrm{Ar}}\right), 135.6\left(C_{\mathrm{Ar}}\right)$, $132.0\left(C_{\mathrm{Ar}}\right), 132.0\left(C_{\mathrm{Ar}}\right), 131.9\left(C_{\mathrm{Ar}}\right), 131.2\left(C_{\mathrm{Ar}}\right), 129.7\left(C_{\mathrm{Ar}}\right), 126.1\left(C_{\mathrm{Ar}}\right), 125.9\left(C_{\mathrm{Ar}}\right)$, $125.5\left(C_{\mathrm{Ar}}\right), 125.4\left(C_{\mathrm{Ar}}\right), 55.3\left(\mathrm{NC}\left(\mathrm{CH}_{3}\right)_{3}\right), 55.3\left(\mathrm{NC}\left(\mathrm{CH}_{3}\right)_{3}\right), 31.4\left(\mathrm{NC}\left(\mathrm{CH}_{3}\right)_{3}\right), 31.4$ $\left(\mathrm{NC}\left(\mathrm{CH}_{3}\right)_{3}\right)$. HR-MS $(\mathrm{m} / \mathrm{z}): 535.37 \quad[\mathrm{M}+\mathrm{H}]^{+}$. Elemental analysis calcd (\%) for $\mathrm{C}_{36} \mathrm{H}_{46} \mathrm{~N}_{4} \cdot \mathrm{C}_{7} \mathrm{H}_{8}: \mathrm{C}, 82.4 ; \mathrm{H}, 8.7 ; \mathrm{N}, 8.9$; found $\mathrm{C}, 82.7 ; \mathrm{H}, 8.5 ; \mathrm{N}, 8.8$.

\section{Synthesis of $\left[\mathrm{H}_{2} \mathrm{G}^{n \mathrm{Bu}}\right]\left(\mathrm{PF}_{6}\right)_{2}$}

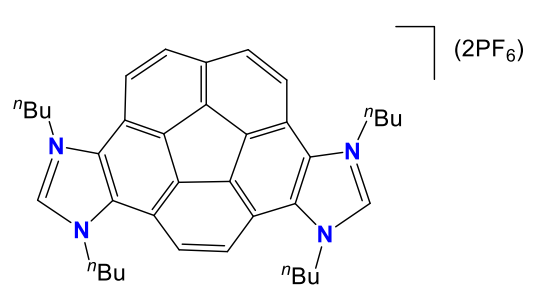

A Schlenk tube containing a mixture of compound $\mathbf{F}$ (150 mg, $0.28 \mathrm{mmol}), 4 \mathrm{~mL}$ of tributyl orthoformate and $\mathrm{NH}_{4} \mathrm{PF}_{6}(150 \mathrm{mg}, 0.92 \mathrm{mmol})$ was heated at 150 ${ }^{\circ} \mathrm{C}$ for $12 \mathrm{~h}$. A sticky precipitate crashed out from an orange solution. The solution was discarded and the precipitate was dissolved in copious amount of methanol. The solution was filtrated and removed under vacuum obtained a pale orange solid. Yield: $168 \mathrm{mg}$ (71\%). The solid was purified by liquid-liquid extraction in $\mathrm{H}_{2} \mathrm{O} / \mathrm{CH}_{2} \mathrm{Cl}_{2}$, then the aqueous phase was removed in vacuum obtained a yellow solid. ${ }^{1} \mathrm{H}$ NMR $\left(300 \mathrm{MHz}, \mathrm{CD}_{3} \mathrm{OD}\right): \delta$ (ppm) $9.86(\mathrm{~s}, 2 \mathrm{H}, \mathrm{NCHN}), 8.50\left(\mathrm{bs}, 2 \mathrm{H}, \mathrm{C} H_{\mathrm{Ar}}\right), 8.33\left(\mathrm{~d}, J=8.8 \mathrm{~Hz}, 2 \mathrm{H}, \mathrm{C} H_{\mathrm{Ar}}\right), 8.22(\mathrm{~d}, J=$ $8.7 \mathrm{~Hz}, 2 \mathrm{H}, \mathrm{CH} \mathrm{Ar}_{\mathrm{Ar}}$ ), 5.04 (m, $\left.8 \mathrm{H}, \mathrm{NCH}_{2} \mathrm{CH}_{2} \mathrm{CH}_{2} \mathrm{CH}_{3}\right), 2.31\left(\mathrm{~m}, 8 \mathrm{H}, \mathrm{NCH}_{2} \mathrm{CH}_{2} \mathrm{CH}_{2} \mathrm{CH}_{3}\right.$ ), 1.75-1.62 (m, 8H, $\left.\mathrm{NCH}_{2} \mathrm{CH}_{2} \mathrm{CH}_{2} \mathrm{CH}_{3}\right), 1.16\left(\mathrm{~m}, 12 \mathrm{H}, \mathrm{NCH}_{2} \mathrm{CH}_{2} \mathrm{CH}_{2} \mathrm{CH}_{3}\right) .{ }^{13} \mathrm{C}\left\{{ }^{1} \mathrm{H}\right\}$ NMR (75.6 MHz, CD $\left.{ }_{3} \mathrm{OD}\right): \delta(\mathrm{ppm}) 140.7(\mathrm{NCHN}), 133.6\left(C_{\mathrm{Ar}}\right), 132.1\left(C_{\mathrm{Ar}}\right), 130.5$ $\left(C_{\mathrm{Ar}}\right), 130.2\left(C_{\mathrm{Ar}}\right), 129.9\left(C_{\mathrm{Ar}}\right), 129.3\left(C_{\mathrm{Ar}}\right), 125.4\left(C_{\mathrm{Ar}}\right), 123.8\left(C_{\mathrm{Ar}}\right), 119.4\left(C_{\mathrm{Ar}}\right), 118.9$ $\left(C_{\mathrm{Ar}}\right), 50.8\left(\mathrm{NCH}_{2} \mathrm{CH}_{2} \mathrm{CH}_{2} \mathrm{CH}_{3}\right), 31.7\left(\mathrm{NCH}_{2} \mathrm{CH}_{2} \mathrm{CH}_{2} \mathrm{CH}_{3}\right), 20.3\left(\mathrm{NCH}_{2} \mathrm{CH}_{2} \mathrm{CH}_{2} \mathrm{CH}_{3}\right)$, $13.9\left(\mathrm{NCH}_{2} \mathrm{CH}_{2} \mathrm{CH}_{2} \mathrm{CH}_{3}\right)$. HR-MS $(m / z): 278.2[\mathrm{M}]^{2+}$ Elemental analysis calcd (\%) for $\mathrm{C}_{38} \mathrm{H}_{44} \mathrm{~N}_{4}\left(\mathrm{PF}_{6}\right)$ : C, 53.9; H, 5.2; N, 6.6; found $\mathrm{C}, 53.2 ; \mathrm{H}, 5.6 ; \mathrm{N}, 6.3$.

\section{Synthesis of $\left[\mathrm{H}_{2} \mathrm{G}^{t \mathrm{Bu}}\right]\left(\mathrm{PF}_{6}\right)_{2}$}

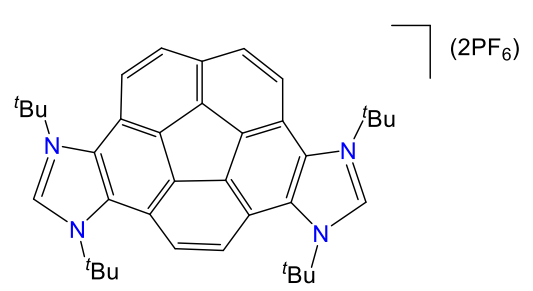

A Schlenk tube containing a mixture of compound $\mathbf{F}$ (150 mg, $0.28 \mathrm{mmol}), 4 \mathrm{~mL}$ of tributyl orthoformate and $\mathrm{NH}_{4} \mathrm{PF}_{6}(150 \mathrm{mg}, 0.92 \mathrm{mmol})$ was stirred at room temperature for 4 days. After this period of time a precipitate crashed out from an orange solution.

Acetone was added over the suspension and filtered over Celite. The solvent was removed under vacuum to yield an orange solid, which was washed with diethyl ether. 
The residue was dissolved in a copious amount of $\mathrm{CH}_{2} \mathrm{Cl}_{2}$ filtered over Celite and the solution was dried under vacuum. The final product was obtained as a yellow solid. Yield: $158 \mathrm{mg}(67 \%) .{ }^{1} \mathrm{H}$ NMR $\left(300 \mathrm{MHz},\left(\mathrm{CD}_{3}\right)_{2} \mathrm{CO}\right): \delta(\mathrm{ppm}) 9.55(\mathrm{~s}, 2 \mathrm{H}, \mathrm{NCHN})$, $9.13\left(\mathrm{~s}, 2 \mathrm{H}, \mathrm{C} H_{\mathrm{Ar}}\right), 8.89$ (d, $\left.J=9 \mathrm{~Hz}, 2 \mathrm{H}, \mathrm{C} H_{\mathrm{Ar}}\right), 8.54$ (d, $\left.J=9 \mathrm{~Hz}, 2 \mathrm{H}, \mathrm{C} H_{\mathrm{Ar}}\right), 2.32(\mathrm{~m}$, $\left.36 \mathrm{H}, \mathrm{NC}\left(\mathrm{CH}_{3}\right)\right) .{ }^{13} \mathrm{C}\left\{{ }^{1} \mathrm{H}\right\} \mathrm{NMR}\left(100.8 \mathrm{MHz},\left(\mathrm{CD}_{3}\right)_{2} \mathrm{CO}\right): \delta(\mathrm{ppm}) 137.8(\mathrm{NCHN})$, $134.1\left(C_{\mathrm{Ar}}\right), 132.4\left(C_{\mathrm{Ar}}\right), 132.3\left(C_{\mathrm{Ar}}\right), 131.6\left(C_{\mathrm{Ar}}\right), 130.5\left(C_{\mathrm{Ar}}\right), 129.8\left(C_{\mathrm{Ar}}\right), 129.1\left(C_{\mathrm{Ar}}\right)$, $120.2\left(C_{\mathrm{Ar}}\right), 119.2\left(\mathrm{C}_{\mathrm{Ar}}\right), 64.1\left(\mathrm{NC}\left(\mathrm{CH}_{3}\right)_{3}\right), 64.0\left(\mathrm{NC}\left(\mathrm{CH}_{3}\right)_{3}\right), 27.7\left(\mathrm{NC}\left(\mathrm{CH}_{3}\right)_{3}\right) . \mathrm{HR}-\mathrm{MS}$ $(m / z): 278.2[\mathrm{M}]^{2+}$ Elemental analysis calcd (\%) for $\mathrm{C}_{38} \mathrm{H}_{44} \mathrm{~N}_{4}\left(\mathrm{PF}_{6}\right): \mathrm{C}, 53.9 ; \mathrm{H}, 5.2 ; \mathrm{N}$, 6.6; found $\mathrm{C}, 53.2 ; \mathrm{H}, 5.6 ; \mathrm{N}, 6.3$.

\section{Synthesis of $\mathrm{G}^{\mathrm{tBu}}$}

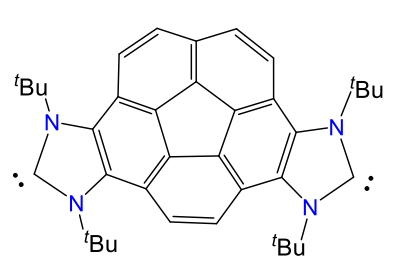

Under inert atmosphere, a NMR tube with a Teflon-lined cap was charged with $\left[\mathbf{H}_{\mathbf{2}} \mathbf{G}^{t \mathbf{B u}}\right]\left(\mathbf{P F}_{\mathbf{6}}\right)_{2} \quad(16 \mathrm{mg}, 0.018 \mathrm{mmol})$, $\mathrm{NaO}{ }^{t} \mathrm{Bu}(1.8 \mathrm{mg}, 0.018 \mathrm{mmol})$ and dried $\mathrm{C}_{6} \mathrm{D}_{6}(0.6 \mathrm{~mL})$. To this suspension, NaHMDS ( $1 \mathrm{M}$ in THF, $49 \mu \mathrm{L}, 0.049 \mathrm{mmol}$ ) was added and the reaction mixture was stirred at room temperature for $2 \mathrm{~h} .{ }^{1} \mathrm{H}$ NMR $\left(500 \mathrm{MHz}, \mathrm{C}_{6} \mathrm{D}_{6}\right): \delta(\mathrm{ppm}) 8.55\left(\mathrm{~s}, 2 \mathrm{H}, \mathrm{C} H_{\mathrm{Ar}}\right), 8.48\left(\mathrm{~d}, J=10.0 \mathrm{~Hz}, 2 \mathrm{H}, \mathrm{C} H_{\mathrm{Ar}}\right), 7.86(\mathrm{~d}$, $\left.J=10.0 \mathrm{~Hz}, 2 \mathrm{H}, \mathrm{CH} H_{\mathrm{Ar}}\right), 2.09\left(\mathrm{~m}, 36 \mathrm{H}, \mathrm{NC}\left(\mathrm{CH}_{3}\right){ }_{3}{ }^{13} \mathrm{C}\left\{{ }^{1} \mathrm{H}\right\} \mathrm{NMR}\left(126 \mathrm{MHz}, \mathrm{C}_{6} \mathrm{D}_{6}\right): \delta\right.$ (ppm) $219.9\left(C_{\text {Carbene }}\right), 132.4\left(C_{\mathrm{Ar}}\right), 131.1\left(C_{\mathrm{Ar}}\right), 130.0\left(C_{\mathrm{Ar}}\right), 128.0\left(C_{\mathrm{Ar}}\right), 127.9\left(C_{\mathrm{Ar}}\right)$, $126.3\left(C_{\mathrm{Ar}}\right), 120.3\left(C_{\mathrm{Ar}}\right), 118.0\left(C_{\mathrm{Ar}}\right), 58.0\left(\mathrm{NC}\left(\mathrm{CH}_{3}\right)_{3}\right), 31.3-31.2\left(\mathrm{NC}\left(\mathrm{CH}_{3}\right)_{3}\right)$.

\subsubsection{Synthesis and characterization of metal complexes: Chapter 2}

\section{Synthesis of $1 \mathrm{~B}^{\mathrm{Me}}$}

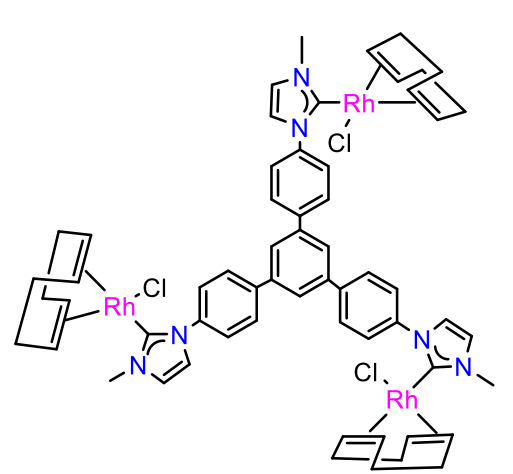

To a Schlenk containing a solution of $\left[\mathbf{H}_{3} \mathbf{B}^{\mathrm{Me}}\right]\left(\mathbf{C F}_{\mathbf{3}} \mathbf{S O}_{3}\right)_{3} \quad(0.100 \mathrm{~g}, \quad 0.10 \mathrm{mmol})$ and $[\mathrm{RhCl}(\mathrm{COD})]_{2}(0.074 \mathrm{~g}, 0.15 \mathrm{mmol})$ in THF $(15 \mathrm{~mL})$ at $78{ }^{\circ} \mathrm{C}$, was added dropwise a solution of KHMDS $(0.5$ $\mathrm{M}$ in toluene, $662 \mu \mathrm{L}, 0.33 \mathrm{mmol})$. The mixture was stirred overnight to room temperature. After removal of the volatiles, the crude solid was dissolved in $\mathrm{CH}_{2} \mathrm{Cl}_{2}$ and purified by column chromatography using silica gel. An orange product was obtained (72 mg). Yield: $56 \%$. ${ }^{1} \mathrm{H}$ NMR (300 MHz, $\left.\mathrm{CDCl}_{3}\right): \delta(\mathrm{ppm}) 8.38(\mathrm{~d}, J=8.5$ $\left.\mathrm{Hz}, 6 \mathrm{H}, \mathrm{C} H_{\mathrm{Ar}}\right), 7.93\left(\mathrm{~m}, 9 \mathrm{H}, \mathrm{CH}_{\mathrm{Imid}}, \mathrm{CH}_{\mathrm{Ar}}\right), 7.25\left(\mathrm{~s}, 3 \mathrm{H}, \mathrm{C} H_{\mathrm{Ar}}\right), 7.02(\mathrm{~d}, J=2.0 \mathrm{~Hz}, 3 \mathrm{H}$, $\mathrm{CH}_{\text {Imid }}$ ), 5.06 (m, 3H, CH $H_{\mathrm{COD}}$ ), 4.24 (s, 9H, $\mathrm{CH}_{3}$ ), 3.29 (br s, 3H, CH $H_{\mathrm{COD}}$ ), 2.64 (br s, 3H, 
$\left.\mathrm{CH}_{\mathrm{COD}}\right), 2.36-2.17$ (m, 12H, CH$\left.H_{2 \mathrm{COD}}\right), 1.61\left(\mathrm{~m}, 12 \mathrm{H}, \mathrm{C} H_{2 \mathrm{COD}}\right) .{ }^{13} \mathrm{C}\left\{{ }^{1} \mathrm{H}\right\} \mathrm{NMR}(75 \mathrm{MHz}$, $\left.\mathrm{CDCl}_{3}\right): \delta(\mathrm{ppm}) 183.8\left(\mathrm{~d}, J=51.2 \mathrm{~Hz}, \mathrm{Rh}-C_{\text {carbene }}\right), 141.9\left(C_{\mathrm{Ar}}\right), 140.4\left(C_{\mathrm{Ar}}\right), 140.0$ $\left(C_{\mathrm{Ar}}\right), 127.8\left(C_{\mathrm{Ar}}\right), 125.4\left(C_{\mathrm{Ar}}\right), 125.3\left(C_{\mathrm{Ar}}\right), 123.0\left(C_{\mathrm{Imid}}\right), 121.2\left(C_{\mathrm{Imid}}\right), 98.3\left(C_{\mathrm{COD}}\right)$, $68.7\left(C_{\mathrm{COD}}\right), 68.5\left(C_{\mathrm{COD}}\right), 68.3\left(C_{\mathrm{COD}}\right), 68.1\left(C_{\mathrm{COD}}\right), 54.0\left(\mathrm{CH}_{3}\right), 38.6\left(C_{\mathrm{COD}}\right), 32.1$ $\left(C_{\mathrm{COD}}\right), 31.0\left(C_{\mathrm{COD}}\right), 29.4\left(C_{\mathrm{COD}}\right), 28.7\left(C_{\mathrm{COD}}\right)$. Electrospray MS $(20 \mathrm{~V}, \mathrm{~m} / \mathrm{z}): 627.7$ [M$2 \mathrm{Cl}+\mathrm{MeCN}]^{2+}$.

\section{Synthesis of $2 B^{E t}$}

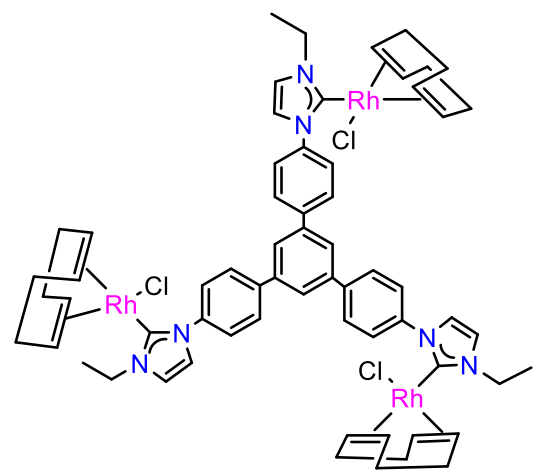

To a Schlenk containing a solution of $\left[\mathbf{H}_{3} \mathbf{B}^{\mathrm{Et}}\right]\left(\mathrm{BF}_{4}\right)_{3}$ $(0.100 \mathrm{~g}, 0.12 \mathrm{mmol})$ and $[\mathrm{RhCl}(\mathrm{COD})]_{2}(0.087 \mathrm{~g}$, $0.18 \mathrm{mmol})$ in THF $(15 \mathrm{~mL})$ at $-78^{\circ} \mathrm{C}$, a solution of KHMDS $(0.5 \mathrm{M}$ in toluene, $774 \mu \mathrm{L}, 0.39 \mathrm{mmol})$ was added dropwise. The mixture was stirred overnight to room temperature. After removal of the volatiles, the crude solid was dissolved in methylene chloride and purified by column chromatography using silica gel. Using mixtures of $\mathrm{CH}_{2} \mathrm{Cl}_{2}$ /acetone, an orange product $(87 \mathrm{mg})$ was obtained. Yield: $56 \%$. ${ }^{1} \mathrm{H}$ NMR $\left(300 \mathrm{MHz}, \mathrm{CDCl}_{3}\right): \delta$ (ppm) $8.39\left(\mathrm{~d}, J=8.4 \mathrm{~Hz}, 6 \mathrm{H}, \mathrm{C} H_{\mathrm{Ar}}\right), 7.96\left(\mathrm{~m}, 9 \mathrm{H}, \mathrm{C} H_{\text {Imid }}, \mathrm{C} H_{\mathrm{Ar}}\right), 7.30\left(\mathrm{~s}, 3 \mathrm{H}, \mathrm{CH}_{\mathrm{Ar}}\right)$, 7.06 (d, $\left.J=2.0 \mathrm{~Hz}, 3 \mathrm{H}, \mathrm{C} H_{\text {Imid }}\right), 5.14$ (m, 3H, CHCOD $), 4.98$ (m, 3H, CH $\left.H_{\mathrm{COD}}\right), 4.78$ (m, 6H, $\mathrm{CH}_{2}$ ), 3.28 (br s, 3H, CH $H_{\mathrm{COD}}$ ), 2.67 (br s, 3H, CH $H_{\mathrm{COD}}$ ), 2.36 (m, 12H, $\mathrm{CH}_{2 \mathrm{COD}}$ ), 2.17 $\left(\mathrm{m}, 12 \mathrm{H}, \mathrm{C} H_{2 \mathrm{COD}}\right), 1.86(\mathrm{~m}, 9 \mathrm{H}, \mathrm{CH}) .{ }^{13} \mathrm{C}\left\{{ }^{1} \mathrm{H}\right\} \mathrm{NMR}\left(75 \mathrm{MHz}, \mathrm{CDCl}_{3}\right): \delta(\mathrm{ppm}) \delta$ $182.9\left(\mathrm{~d}, J=51.3 \mathrm{~Hz}, \mathrm{Rh}-C_{\text {carbene }}\right), 141.9\left(C_{\mathrm{Ar}}\right), 140.32\left(C_{\mathrm{Ar}}\right), 140.2\left(C_{\mathrm{Ar}}\right), 127.7\left(C_{\mathrm{Ar}}\right)$, $125.4\left(C_{\mathrm{Ar}}\right), 125.3\left(C_{\mathrm{Ar}}\right), 121.6\left(C_{\mathrm{Imid}}\right), 120.6\left(C_{\mathrm{Imid}}\right), 97.9\left(C_{\mathrm{COD}}\right), 68.9\left(C_{\mathrm{COD}}\right), 68.8$ $\left(C_{\mathrm{COD}}\right), 68.5\left(C_{\mathrm{COD}}\right), 68.3\left(C_{\mathrm{COD}}\right), 46.6\left(\mathrm{CH}_{2}\right), 33.5\left(C_{\mathrm{COD}}\right), 32.0\left(C_{\mathrm{COD}}\right), 29.8\left(C_{\mathrm{COD}}\right)$, $29.2\left(C_{\mathrm{COD}}\right), 28.6\left(\mathrm{C}_{\mathrm{COD}}\right), 16.2\left(\mathrm{CH}_{3}\right)$. Electrospray MS $(20 \mathrm{~V}, \mathrm{~m} / \mathrm{z}): 648.8[\mathrm{M}-$ $2 \mathrm{Cl}+\mathrm{MeCN}]^{2+}$. Elemental analysis calcd (\%) for $\mathrm{C}_{63} \mathrm{H}_{72} \mathrm{~N}_{6} \mathrm{Rh}_{3} \mathrm{Cl}_{3} \cdot 2 \mathrm{H}_{2} \mathrm{O} \cdot \mathrm{CH}_{2} \mathrm{Cl}_{2}: \mathrm{C}$, 53.0; H, 5.4; N, 5.8; found C, 53.0; H, 6.0; N, 5.6. 


\section{Synthesis of $3 B^{\text {Et }}$}

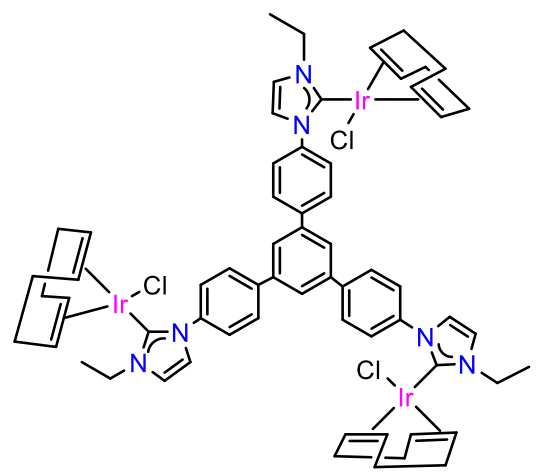

A solution of KHMDS $(0,5 \mathrm{M}$ in toluene, $774 \mu \mathrm{L}, 0.39$ mmol) was added dropwise to a Schlenk tube containing a solution of $\left[\mathbf{H}_{3} \mathbf{B}^{\mathrm{Et}}\right]\left(\mathbf{B F}_{4}\right)_{3}(0.10 \mathrm{~g}, 0.12$ $\mathrm{mmol})$ and $[\mathrm{IrCl}(\mathrm{COD})]_{2}(0.12 \mathrm{~g}, 0.18 \mathrm{mmol})$ in $\mathrm{THF}$ $(15 \mathrm{~mL})$ at $-78^{\circ} \mathrm{C}$. The mixture was stirred overnight at room temperature. After removal of the volatiles, the crude mixture was dissolved in $\mathrm{CH}_{2} \mathrm{Cl}_{2}$ and purified by column chromatography using silica gel $\left(\mathrm{CH}_{2} \mathrm{Cl}_{2}\right.$ /acetone), to yield $79 \mathrm{mg}$ of an orange product. Yield: $42 \%$. ${ }^{1} \mathrm{H}$ NMR (300 $\left.\mathrm{MHz}, \mathrm{CDCl}_{3}\right): \delta(\mathrm{ppm}) 8.20\left(\mathrm{~d}, J=8.4 \mathrm{~Hz}, 6 \mathrm{H}, \mathrm{CH} H_{\mathrm{Ar}}\right), 7.92-7.83\left(\mathrm{~m}, 9 \mathrm{H}, \mathrm{CH}_{\text {Imid }}, \mathrm{CH}_{\mathrm{Ar}}\right)$, $7.23\left(\mathrm{~d}, J=1.9 \mathrm{~Hz}, 3 \mathrm{H}, \mathrm{C} H_{\mathrm{Ar}}\right), 7.06$ (d, $\left.J=2.0 \mathrm{~Hz}, 3 \mathrm{H}, \mathrm{C} H_{\text {Imid }}\right), 4.72-4.51(\mathrm{~m}, 12 \mathrm{H}$, $\mathrm{CH}_{\mathrm{COD}}, \mathrm{CH}_{2}$ ), 2.89 (m, 3H, CHCOD), 2.34-2.14 (m, 12H, $\left.\mathrm{CH}_{2 \mathrm{COD}}\right), 1.91-1.84$ (m, 3H, $\left.\mathrm{CH}_{\mathrm{COD}}\right), 1.61-1.47\left(\mathrm{~m}, 21 \mathrm{H}, \mathrm{CH}_{2 \mathrm{COD}}, \mathrm{CH}_{3}\right) .{ }^{13} \mathrm{C}\left\{{ }^{1} \mathrm{H}\right\} \mathrm{NMR}\left(75 \mathrm{MHz}, \mathrm{CDCl}_{3}\right): \delta(\mathrm{ppm}) \delta$ $180.3\left(\operatorname{Ir}-C_{\text {carbene }}\right), 142.0\left(C_{\mathrm{Ar}}\right), 140.3\left(C_{\mathrm{Ar}}\right), 140.0\left(C_{\mathrm{Ar}}\right), 127.6\left(C_{\mathrm{Ar}}\right), 125.8\left(C_{\mathrm{Ar}}\right), 125.4$ $\left(C_{\mathrm{Ar}}\right), 121.4\left(C_{\mathrm{Imid}}\right), 120.4\left(C_{\mathrm{Imid}}\right), 84.3\left(C_{\mathrm{COD}}\right), 83.8\left(C_{\mathrm{COD}}\right), 68.6\left(C_{\mathrm{COD}}\right), 52.3\left(C_{\mathrm{COD}}\right)$, $52.2\left(C_{\mathrm{COD}}\right), 46.4\left(\mathrm{CH}_{2}\right), 34.1\left(C_{\mathrm{COD}}\right), 32.8\left(C_{\mathrm{COD}}\right), 29.8\left(C_{\mathrm{COD}}\right), 29.6\left(C_{\mathrm{COD}}\right), 29.5$ $\left(C_{\mathrm{COD}}\right), 28.0\left(C_{\mathrm{COD}}\right), 16.1\left(\mathrm{CH}_{3}\right)$. Electrospray MS $(20 \mathrm{~V}, \mathrm{~m} / z): 783.2[\mathrm{M}-2 \mathrm{Cl}+\mathrm{MeCN}]^{2+}$. Elemental analysis calcd (\%) for $\mathrm{C}_{63} \mathrm{H}_{72} \mathrm{~N}_{6} \mathrm{Ir}_{3} \mathrm{Cl}_{3} \cdot 2 \mathrm{H}_{2} \mathrm{O} \cdot 2 \mathrm{CH}_{2} \mathrm{Cl}_{2}$ : C, 43.3; $\mathrm{H}, 4.5 ; \mathrm{N}, 4.7$; found $\mathrm{C}, 43.0 ; \mathrm{H}, 3.3 ; \mathrm{N}, 4.5$.

\section{Synthesis of $4 B^{E t}$}

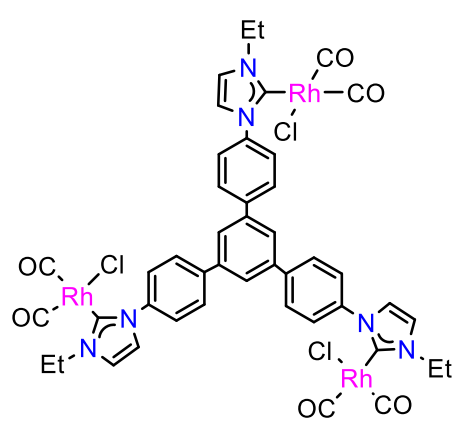

CO gas was bubbled through a solution of $\mathbf{1 B}^{\mathbf{M e}}$ in dichloromethane $(10 \mathrm{~mL})$ at $0{ }^{\circ} \mathrm{C}$ for $30 \mathrm{~min}$. The solution was concentrated by evaporation of the solvent under reduced pressure. Addition of hexanes allowed the precipitation of $\mathbf{4} \mathbf{B}^{\mathbf{E t}}$ as a yellow solid (59 $\mathrm{mg}$ ). Yield: 90 \%. ${ }^{1} \mathrm{H}$ NMR (300 MHz, $\left.\mathrm{CDCl}_{3}\right): \delta$ (ppm) 7.92-7.87 (m, 15H, $\mathrm{CH}_{\mathrm{Ar}}$ ), 7.36 (br s, 3H, $\mathrm{CH}_{\text {Imid }}$ ), 7.20 (br s, 3H, $\mathrm{CH}_{\text {Imid }}$ ), 4.98 (br s, 6H, $\mathrm{CH}_{2}$ ), 1.61 $(\mathrm{s}, 9 \mathrm{H}, \mathrm{CH}) .{ }^{13} \mathrm{C}\left\{{ }^{1} \mathrm{H}\right\}$ NMR $\left(75 \mathrm{MHz}, \mathrm{CDCl}_{3}\right): \delta(\mathrm{ppm}) 185.6(\mathrm{~d}, J=54.3 \mathrm{~Hz}, \mathrm{Rh}-$ $C_{\text {carbene }}$ ), 182.2 (d, $\left.J=74.7 \mathrm{~Hz}, \mathrm{Rh}-C \mathrm{O}\right), 173.9$ (d, $\left.J=43.6 \mathrm{~Hz}, \mathrm{Rh}-C \mathrm{O}\right), 141.1\left(C_{\mathrm{Ar}}\right)$, $141.0\left(C_{\mathrm{Ar}}\right), 139.2\left(C_{\mathrm{Ar}}\right), 128.0\left(C_{\mathrm{Ar}}\right), 125.8\left(C_{\mathrm{Ar}}\right), 125.4\left(C_{\mathrm{Ar}}\right), 122.7\left(C_{\mathrm{Imid}}\right), 121.6$ $\left(C_{\text {Imid }}\right), 46.8\left(\mathrm{CH}_{2}\right), 16.0\left(\mathrm{CH}_{3}\right)$. Electrospray MS $(20 \mathrm{~V}, \mathrm{~m} / z): 1188.8$ [M-CO$\mathrm{Cl}+2 \mathrm{MeCN}]^{+}, \quad 1106.8 \quad[\mathrm{M}-\mathrm{CO}-\mathrm{Cl}]^{+}$. Elemental analysis calcd (\%) for 
$\mathrm{C}_{45} \mathrm{H}_{36} \mathrm{~N}_{6} \mathrm{Rh}_{3} \mathrm{Cl}_{3} \mathrm{O}_{6} 2 \mathrm{H}_{2} \mathrm{O}: \mathrm{C}, 44.8 ; \mathrm{H}, 3.3 ; \mathrm{N}, 6.8$; found $\mathrm{C}, 44.4 ; \mathrm{H}, 3.8 ; \mathrm{N}, 6.8 ; \mathrm{IR}\left(\mathrm{cm}^{-}\right.$ $\left.{ }^{1}\right)$ : 2072, 1991; TEP: 2045.

\section{Synthesis of $5 B^{\text {Et }}$}

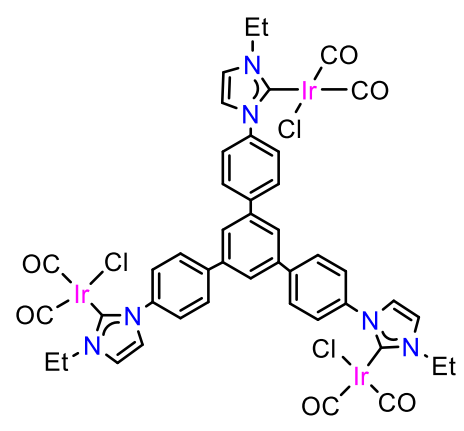

CO was bubbled through a solution of $\mathbf{3} \mathbf{B}^{\mathbf{E t}}$ in dichloromethane $(10 \mathrm{~mL})$ at $0{ }^{\circ} \mathrm{C}$ for $30 \mathrm{~min}$. The solution was concentrated by evaporation of the solvent under reduced pressure. A yellow precipitate was obtained after addition of hexanes to the residue $(78 \mathrm{mg})$. Yield: $87 \% .{ }^{1} \mathrm{H}$ NMR (300 MHz, $\left.\mathrm{CDCl}_{3}\right): \delta(\mathrm{ppm}) 7.90$ (br s, 3H, $\mathrm{CH}_{\mathrm{Ar}}$ ), 7.84 (br s, $\left.12 \mathrm{H}, \mathrm{C} H_{\mathrm{Ar}}\right), 7.32$ (br s, $3 \mathrm{H}, \mathrm{CH}_{\text {Imid }}$ ), 7.21 (br s, $3 \mathrm{H}, \mathrm{CH}_{\text {Imid }}$ ), 4.52 (br s, 6H, CH$\left.H_{2}\right), 1.59\left(\mathrm{~s}, 9 \mathrm{H}, \mathrm{CH}_{3}\right) .{ }^{13} \mathrm{C}\left\{{ }^{1} \mathrm{H}\right\} \mathrm{NMR}\left(75 \mathrm{MHz}, \mathrm{CDCl}_{3}\right)$ : $\delta$ (ppm) 181.1 (Ir- $\left.C_{\text {carbene }}\right), 173.3(\operatorname{Ir}-C O), 167.8(\operatorname{Ir}-C O), 141.4\left(C_{\mathrm{Ar}}\right), 141.3\left(C_{\mathrm{Ar}}\right), 139.1$ $\left(C_{\mathrm{Ar}}\right), 128.1\left(C_{\mathrm{Ar}}\right), 126.7\left(C_{\mathrm{Ar}}\right), 125.7\left(C_{\mathrm{Ar}}\right), 122.8\left(C_{\text {Imid }}\right), 121.4\left(C_{\mathrm{Imid}}\right), 46.9\left(C_{2}\right)$, $16.0\left(\mathrm{CH}_{3}\right)$. Electrospray MS $(20 \mathrm{~V}, \mathrm{~m} / z): 1506.9[\mathrm{M}-3 \mathrm{Cl}-3 \mathrm{CO}+6 \mathrm{MeCN}]^{+} . \mathrm{IR}\left(\mathrm{cm}^{-1}\right)$ : 2061, 1975; TEP: $2045 \mathrm{~cm}^{-1}$.

\section{Synthesis of $1 D^{\mathrm{Et}}$}

To a Schlenk tube containing a solution of $\left[\mathbf{H D}^{\mathrm{Et}}\right]\left(\mathbf{B F}_{4}\right)(0.100 \mathrm{~g}, 0.38$

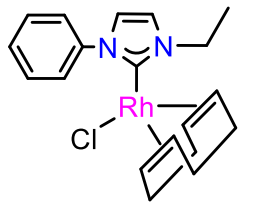
$\mathrm{mmol})$ and $[\mathrm{RhCl}(\mathrm{COD})]_{2}(0.095 \mathrm{~g}, 0.19 \mathrm{mmol})$ in THF $(15 \mathrm{~mL})$ at -78

${ }^{\circ} \mathrm{C}$, a solution of KHMDS was added dropwise $(0.5 \mathrm{M}$ in toluene, 845 $\mu \mathrm{L}, 0.42 \mathrm{mmol})$. The mixture was stirred overnight at room temperature. After removal of the volatiles, the crude solid was dissolved in methylene chloride and purified by column chromatography using the mixture of $\left(\mathrm{CH}_{2} \mathrm{Cl}_{2}\right.$ /acetone $)$ to yield $0.142 \mathrm{~g}$ of a yellow solid. Yield: $89 \%$. ${ }^{1} \mathrm{H}$ NMR $\left(300 \mathrm{MHz}, \mathrm{CDCl}_{3}\right): \delta(\mathrm{ppm})$ 8.18-8.15 (m, 2H, CHAr $), 7.56-7.44\left(\mathrm{~m}, 3 \mathrm{H}, \mathrm{C} H_{\mathrm{Ar}}\right), 7.14\left(\mathrm{~d}, J=1.9 \mathrm{~Hz}, 1 \mathrm{H}, \mathrm{CH}_{\text {Imid }}\right)$, 7.01 (d, $\left.J=1.9 \mathrm{~Hz}, 1 \mathrm{H}, \mathrm{C} H_{\text {Imid }}\right), 5.08$ (m, 1H, CH $\left.H_{\mathrm{COD}}\right), 4.93$ (m, 1H, CHCOD $), 4.82-4.67$ (m, 2H, $\left.\mathrm{CH}_{2}\right), 3.21\left(\mathrm{~m}, 1 \mathrm{H}, \mathrm{C} H_{\mathrm{COD}}\right), 2.54$ (m, 1H, CH $\left.H_{\mathrm{COD}}\right), 1.81-1.77$ (m, 4H, CH $\left.H_{\mathrm{COD}}\right)$, 1.62-1.57 (m, 3H, CH $\left.H_{3}\right) .{ }^{13} \mathrm{C}\left\{{ }^{1} \mathrm{H}\right\}$ NMR $\left(75 \mathrm{MHz}, \mathrm{CDCl}_{3}\right): \delta(\mathrm{ppm}) 182.6(\mathrm{~d}, J=51.2$ $\left.\mathrm{Hz}, \mathrm{Rh}-C_{\text {carbene }}\right), 140.4\left(C_{\mathrm{Ar}}\right), 128.8\left(C_{\mathrm{Ar}}\right), 127.8\left(C_{\mathrm{Ar}}\right), 124.7\left(C_{\mathrm{Ar}}\right), 121.4\left(C_{\text {Imid }}\right), 120.3$ $\left(C_{\text {Imid }}\right), 97.7\left(C_{\mathrm{COD}}\right), 97.6\left(C_{\mathrm{COD}}\right), 97.5\left(C_{\mathrm{COD}}\right), 97.4\left(C_{\mathrm{COD}}\right), 68.6\left(C_{\mathrm{COD}}\right), 68.1\left(C_{\mathrm{COD}}\right)$, $46.3\left(\mathrm{CH}_{2}\right), 33.4\left(C_{\mathrm{COD}}\right), 31.7\left(C_{\mathrm{COD}}\right), 28.9\left(C_{\mathrm{COD}}\right), 28.4\left(C_{\mathrm{COD}}\right), 16.0\left(\mathrm{CH}_{3}\right)$. Electrospray MS $(20 \mathrm{~V}, \mathrm{~m} / \mathrm{z}): 383.2[\mathrm{M}-\mathrm{Cl}], 424.2[\mathrm{M}-\mathrm{Cl}+\mathrm{MeCN}]^{+}$. Elemental analysis calcd (\%) for $\mathrm{C}_{19} \mathrm{H}_{24} \mathrm{~N}_{2} \mathrm{RhCl}$ : C, 54.5; H, 5.8; N, 6.7; found C, 53.3; H, 6.7; N, 6.9. 


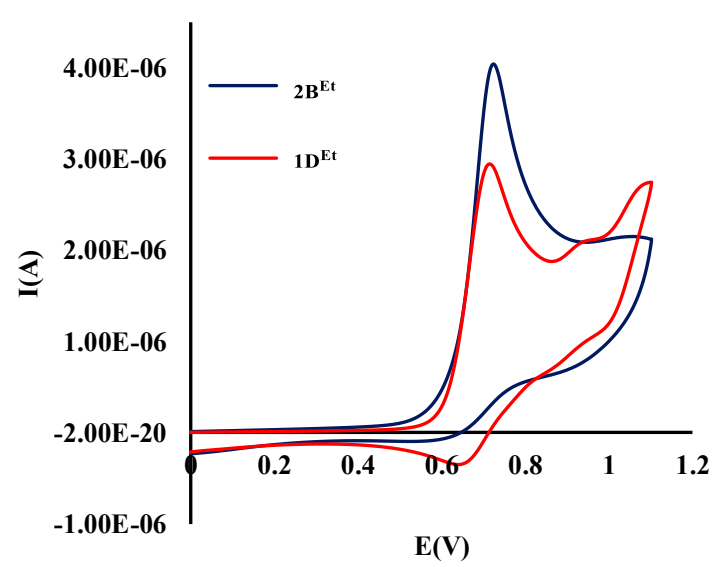

Figure 5.3. $\mathrm{CV}$ plot of complexes $\mathbf{2} \mathbf{B}^{\mathbf{E t}}$ and $\mathbf{1} \mathbf{D}^{\mathbf{E t}}\left(1 \mathrm{mM}\right.$ in dry $\mathrm{CH}_{2} \mathrm{Cl}_{2}$ with $0.1 \mathrm{M}\left[\mathrm{NBu}_{4}\right]\left[\mathrm{PF}_{6}\right]$ as the supporting electrolyte, $50 \mathrm{mVs}^{-1}$ scan rate, $\mathrm{Fc}^{+} / \mathrm{Fc}$ used as internal standard with $\mathrm{E}_{1 / 2}\left(\mathrm{Fc} / \mathrm{Fc}^{+}\right)=0.44 \mathrm{~V}$ vs. SCE).

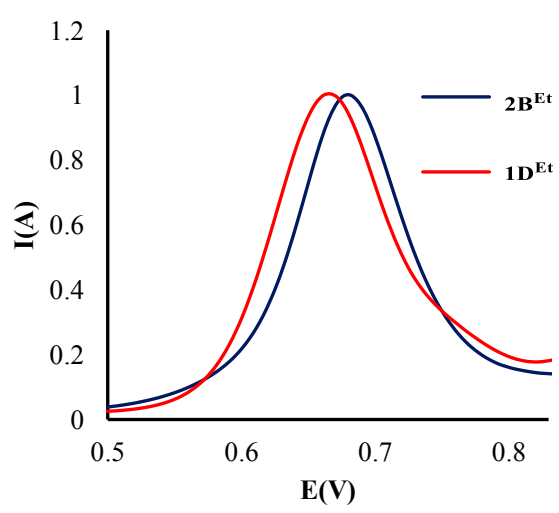

Figure 5.4. DPV section of complexes $\mathbf{2} \mathbf{B}^{\mathbf{E t}}$ and $\mathbf{1} \mathbf{D}^{\mathbf{E t}}\left(1 \mathrm{mM}\right.$ in $\operatorname{dry} \mathrm{CH}_{2} \mathrm{Cl}_{2}$ with $0.1 \mathrm{M}\left[\mathrm{NBu}_{4}\right]\left[\mathrm{PF}_{6}\right]$ as the supporting electrolyte, $50 \mathrm{mVs}^{-1}$ scan rate, $\mathrm{Fc}^{+} / \mathrm{Fc}$ used as internal standard with $\mathrm{E}_{1 / 2}\left(\mathrm{Fc} / \mathrm{Fc}^{+}\right)=0.44 \mathrm{~V}$ vs.

$\mathrm{SCE})$.

\section{Synthesis of $2 D^{\text {Et }}$}

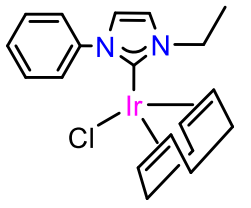

To a Schlenk containing a solution of $\left[\mathbf{H D}^{\mathbf{E t}}\right]\left(\mathbf{B F}_{4}\right)(0.100 \mathrm{~g}, 0.38$ $\mathrm{mmol})$ and $[\mathrm{IrCl}(\mathrm{COD})]_{2}(129 \mathrm{mg}, 0.18 \mathrm{mmol})$ in THF $(15 \mathrm{~mL})$ at -78 ${ }^{\circ} \mathrm{C}$, a (0.5M in toluene solution) of KHMDS $(980 \mu \mathrm{L}, 0.49 \mathrm{mmol})$ was added dropwise. The mixture was stirred overnight at room temperature. After removal of the volatiles, the crude was dissolved in methylene chloride and purified by column chromatography using silica gel $\left(\mathrm{CH}_{2} \mathrm{Cl}_{2}\right.$ /acetone), to yield $0.130 \mathrm{~g}$ of a yellow solid. Yield: $60 \%$. ${ }^{1} \mathrm{H}$ NMR $\left(300 \mathrm{MHz}, \mathrm{CDCl}_{3}\right): \delta(\mathrm{ppm})$ 8.01-7.98 (m, 2H, CHAr $)$, 7.49-7.41 (m, 3H, CHAr), 7.14 (d, $\left.J=1.9 \mathrm{~Hz}, 1 \mathrm{H}, \mathrm{C} H_{\text {Imid }}\right)$, $7.01\left(\mathrm{~d}, J=1.9 \mathrm{~Hz}, 1 \mathrm{H}, \mathrm{C} H_{\text {Imid }}\right), 4.71-4.46\left(\mathrm{~m}, 4 \mathrm{H}, \mathrm{CH}_{2 \mathrm{COD}}, \mathrm{CH}_{2}\right), 2.84(\mathrm{~m}, 1 \mathrm{H}$, $\left.\mathrm{CH}_{\mathrm{COD}}\right), 2.25-2.11\left(\mathrm{~m}, 4 \mathrm{H}, \mathrm{CH}_{2 \mathrm{COD}}\right), 1.95-1.83$ (m, $\left.1 \mathrm{H}, \mathrm{C} H_{\mathrm{COD}}\right), 1.58-1.49$ (m, 6H, $\left.\mathrm{CH}_{2 \mathrm{COD}}, \mathrm{CH}_{3}\right), 1.39-1.20\left(\mathrm{~m}, 1 \mathrm{H}, \mathrm{CH}_{2} \mathrm{COD}\right) .{ }^{13} \mathrm{C}\left\{{ }^{1} \mathrm{H}\right\} \mathrm{NMR}\left(75 \mathrm{MHz}, \mathrm{CDCl}_{3}\right): \delta(\mathrm{ppm})$ 
180.1 (Ir- $\left.C_{\text {carbene }}\right), 140.3\left(C_{\mathrm{Ar}}\right), 128.7\left(C_{\mathrm{Ar}}\right), 127.8\left(C_{\mathrm{Ar}}\right), 125.3\left(C_{\mathrm{Ar}}\right), 121.4\left(C_{\text {Imid }}\right), 120.2$ $\left(C_{\mathrm{Imid}}\right), 84.0\left(C_{\mathrm{COD}}\right), 83.4\left(C_{\mathrm{COD}}\right), 52.1\left(C_{\mathrm{COD}}\right), 52.0\left(C_{\mathrm{COD}}\right), 46.2\left(\mathrm{CH}_{2}\right), 34.1\left(C_{\mathrm{COD}}\right)$, $32.6\left(C_{\mathrm{COD}}\right), 29.5\left(C_{\mathrm{COD}}\right), 29.4\left(C_{\mathrm{COD}}\right), 16.2\left(\mathrm{CH}_{3}\right)$. Electrospray MS $(20 \mathrm{~V}, \mathrm{~m} / z): 514.1$ $[\mathrm{M}-\mathrm{Cl}+\mathrm{MeCN}]^{+}$. Elemental analysis calcd (\%) for $\mathrm{C}_{19} \mathrm{H}_{24} \mathrm{~N}_{2} \mathrm{IrCl} \cdot 1 / 2\left(\mathrm{C}_{6} \mathrm{H}_{14}\right) \cdot \mathrm{H}_{2} \mathrm{O}: \mathrm{C}$, 46.4; H, 5.8; N, 4.9; found $\mathrm{C}, 46.1 ; \mathrm{H}, 6.5 ; \mathrm{N}, 5.5$.

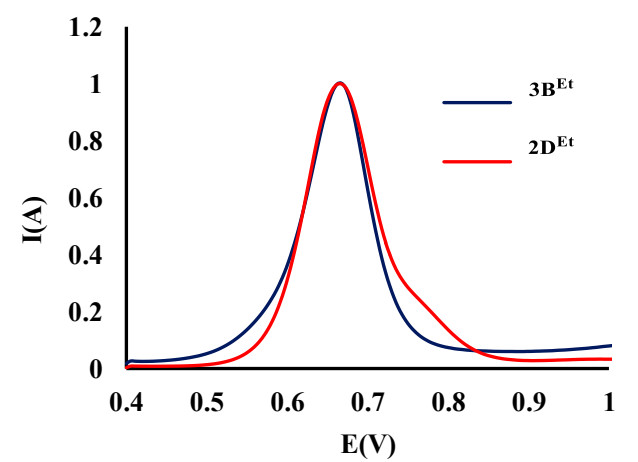

Figure 5.5. DPV section of complexes $\mathbf{3} \mathbf{B}^{\mathbf{E t}}$ and $\mathbf{2} \mathbf{D}^{\mathrm{Et}}\left(1 \mathrm{mM}\right.$ in dry $\mathrm{CH}_{2} \mathrm{Cl}_{2}$ with $0.1 \mathrm{M}\left[\mathrm{NBu}_{4}\right]\left[\mathrm{PF}_{6}\right]$ as the supporting electrolyte, $50 \mathrm{mVs}^{-1}$ scan rate, $\mathrm{Fc}^{+} / \mathrm{Fc}$ used as internal standard with $\mathrm{E}_{1 / 2}\left(\mathrm{Fc}_{\mathrm{Fc}} / \mathrm{Fc}^{+}\right)=0.44 \mathrm{~V}$ vs.

SCE).

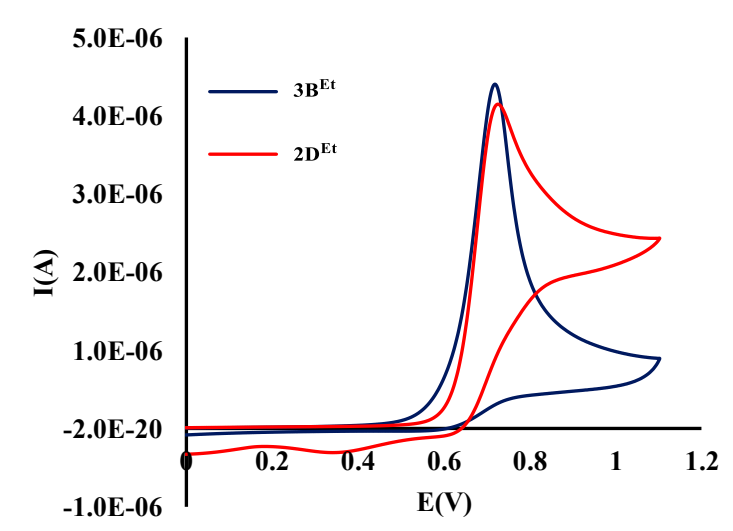

Figure 5.6. $\mathrm{CV}$ plot of complexes $\mathbf{3} \mathbf{B}^{\mathrm{Et}}$ and $\mathbf{2} \mathbf{D}^{\mathrm{Et}}\left(1 \mathrm{mM}\right.$ in dry $\mathrm{CH}_{2} \mathrm{Cl}_{2}$ with $0.1 \mathrm{M}\left[\mathrm{NBu}_{4}\right]\left[\mathrm{PF}_{6}\right]$ as the supporting electrolyte, $50 \mathrm{mVs}^{-1}$ scan rate, $\mathrm{Fc}^{+} / \mathrm{Fc}$ used as internal standard with $\mathrm{E}_{1 / 2}\left(\mathrm{Fc}_{\mathrm{Fc}} / \mathrm{Fc}^{+}\right)=0.44 \mathrm{~V}$ vs. SCE). 


\section{Synthesis of $1 C^{\text {Mes }}$}

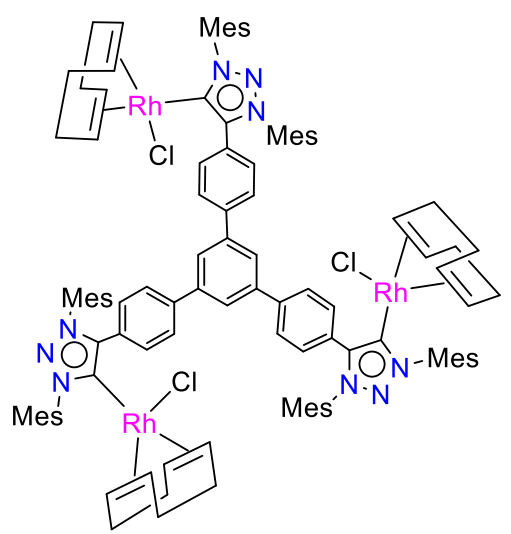

To a Schlenk containing a solution of tris-triazolium salt $\left[\mathbf{H}_{\mathbf{3}} \mathbf{C}^{\mathbf{M e s}}\right]\left(\mathbf{P F}_{\mathbf{6}}\right)_{3} \quad(0.05 \mathrm{~g}, \quad 0.03 \quad \mathrm{mmol})$ and $[\mathrm{RhCl}(\mathrm{COD})]_{2}(0.031 \mathrm{~g}, 0.06 \mathrm{mmol})$ in THF $(15 \mathrm{~mL})$ at $-78^{\circ} \mathrm{C}$, was added dropwise a solution of KHMDS $(0.5$ $\mathrm{M}$ in toluene, $400 \mu \mathrm{L}, 0.20 \mathrm{mmol}$ ). The mixture was allowed to warm up to room temperature and stirred overnight. After removal of the volatiles, the crude solid was dissolved in $\mathrm{CH}_{2} \mathrm{Cl}_{2}$ and purified by column chromatography using silica gel and a DCM/Acetone mixture, to yield $55 \mathrm{mg}$ of an orange solid. Yield: $84 \% .{ }^{1} \mathrm{H}$ NMR $\left(300 \mathrm{MHz}, \mathrm{CDCl}_{3}\right): \delta(\mathrm{ppm}) 8.32$ (d, $J=7.9 \mathrm{~Hz}$, $\left.6 \mathrm{H}, \mathrm{C} H_{\mathrm{Ar}}\right), 7.84\left(\mathrm{~s}, 3 \mathrm{H}, \mathrm{C} H_{\mathrm{Ar}}\right), 7.72\left(\mathrm{~d}, J=8.6 \mathrm{~Hz}, 6 \mathrm{H}, \mathrm{C} H_{\mathrm{Ar}}\right), 7.14-7.02(\mathrm{~m}, 12 \mathrm{H}$, $\left.\mathrm{CH}_{\mathrm{Ar}}\right), 4.82\left(\mathrm{~m}, 6 \mathrm{H}, \mathrm{C} H_{\mathrm{COD}}\right), 3.27$ (m, 6H, CHCOD), 3.39 (m, 36H, $\left.\mathrm{CH}_{3}\right), 2.11-1.98$ (m, $\left.42 \mathrm{H}, \mathrm{CH}_{3}, \mathrm{C} H_{\mathrm{COD}}\right) .{ }^{13} \mathrm{C}\left\{{ }^{1} \mathrm{H}\right\} \mathrm{NMR}\left(75 \mathrm{MHz}, \mathrm{CDCl}_{3}\right): \delta(\mathrm{ppm}) 173.4(\mathrm{~d}, J=41.5 \mathrm{~Hz}$, Rh- $\left.C_{\text {carbene }}\right), 145.8\left(C_{\mathrm{Ar}}\right), 141.6\left(C_{\mathrm{Ar}}\right), 141.2\left(C_{\mathrm{Ar}}\right), 140.0\left(C_{\mathrm{Ar}}\right), 136.7\left(C_{\mathrm{Ar}}\right), 135.0\left(C_{\mathrm{Ar}}\right)$, 134.1 $\left(C_{\mathrm{Ar}}\right), 133.9\left(C_{\mathrm{Ar}}\right), 132.3\left(C_{\mathrm{Ar}}\right), 129.9\left(C_{\mathrm{Ar}}\right), 128.3\left(C_{\mathrm{Ar}}\right), 127.9\left(C_{\mathrm{Ar}}\right), 126.9\left(C_{\mathrm{Ar}}\right)$, $125.3\left(C_{\mathrm{Ar}}\right), 95.9(), 95.4\left(C_{\mathrm{COD}}\right), 69.3\left(C_{\mathrm{COD}}\right), 67.1\left(C_{\mathrm{COD}}\right), 33.7\left(C_{\mathrm{COD}}\right), 32.0\left(C_{\mathrm{COD}}\right)$, $29.4\left(C_{\mathrm{COD}}\right), 28.5\left(\mathrm{C}_{\mathrm{COD}}\right), 21.4\left(\mathrm{CH}_{3}\right), 19.6\left(\mathrm{CH}_{3}\right), 17.9\left(\mathrm{CH}_{3}\right), 17.7\left(\mathrm{CH}_{3}\right) . \mathrm{HR}-\mathrm{MS}$ $(m / z): 616.6[\mathrm{M}]^{3+}, 942.3[\mathrm{M}-\mathrm{Cl}]^{2+}$.

\section{Synthesis of $2 C^{\text {Mes }}$}

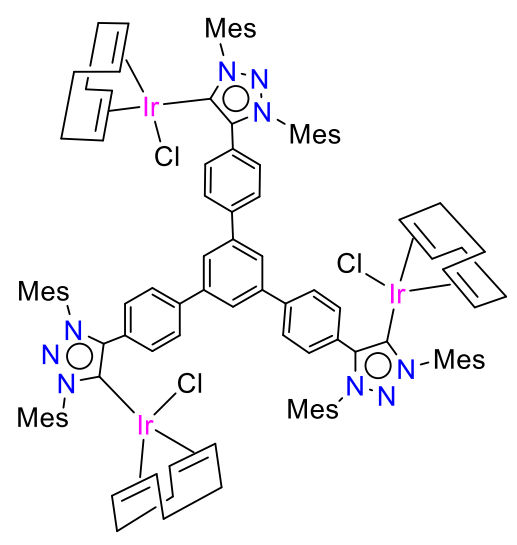

A Schlenk was charged with tris-triazolium salt $\left[\begin{array}{lllll}\mathbf{H}_{3} \mathbf{C}^{\mathbf{M e s}} & \left.\mathbf{P F F}_{6}\right)_{3} & (0.05 & \mathrm{g}, & 0.03 \mathrm{mmol}), \quad[\mathrm{IrCl}(\mathrm{COD})]_{2}\end{array}\right.$ (0.043 g, $0.06 \mathrm{mmol})$ and $\mathrm{K}_{2} \mathrm{CO}_{3}(0.54 \mathrm{~g}, 0.39 \mathrm{mmol})$. The resulting mixture was suspended in acetone (10 $\mathrm{mL}$ ) and stirred for 1 day at $60^{\circ} \mathrm{C}$. After this period of time the solid was filtered and washed several times with acetone. The crude mixture was dissolved in $\mathrm{CH}_{2} \mathrm{Cl}_{2}$ and purified by filtration through a pad of celite. The resulting solution was concentrated to dryness obtained $40 \mathrm{mg}$ of a yellow solid. Yield: $60 \%$. ${ }^{1} \mathrm{H}$ NMR $\left(300 \mathrm{MHz}, \mathrm{CDCl}_{3}\right): \delta(\mathrm{ppm}) 8.05(\mathrm{~d}, J=7.4 \mathrm{~Hz}, 6 \mathrm{H}$, $\left.\mathrm{C}_{\mathrm{Ar}}\right), 7.78\left(\mathrm{~s}, 3 \mathrm{H}, \mathrm{C} H_{\mathrm{Ar}}\right), 7.63\left(\mathrm{~d}, J=7.8 \mathrm{~Hz}, 6 \mathrm{H}, \mathrm{C} H_{\mathrm{Ar}}\right), 7.08-7.00\left(\mathrm{~m}, 12 \mathrm{H}, \mathrm{C} H_{\mathrm{Ar}}\right)$, 4.40 (m, 6H, CH $\left.H_{\mathrm{COD}}\right), 2.94\left(\mathrm{~m}, 6 \mathrm{H}, \mathrm{C} H_{\mathrm{COD}}\right), 2.57-2.27\left(\mathrm{~m}, 36 \mathrm{H}, \mathrm{CH}_{3}\right), 2.04(\mathrm{~m}, 42 \mathrm{H}$, $\left.\mathrm{CH}_{3}, \mathrm{CH}_{\mathrm{COD}}\right) .{ }^{13} \mathrm{C}\left\{{ }^{1} \mathrm{H}\right\} \mathrm{NMR}\left(75 \mathrm{MHz}, \mathrm{CDCl}_{3}\right): \delta(\mathrm{ppm}) 172.1$ (Ir- $\left.C_{\text {carbene }}\right), 146.3\left(C_{\mathrm{Ar}}\right)$, 
$141.6\left(C_{\mathrm{Ar}}\right), 141.3\left(C_{\mathrm{Ar}}\right), 141.2\left(C_{\mathrm{Ar}}\right), 140.0\left(C_{\mathrm{Ar}}\right), 136.5\left(C_{\mathrm{Ar}}\right), 135.1\left(C_{\mathrm{Ar}}\right), 134.2\left(C_{\mathrm{Ar}}\right)$, $134.0\left(C_{\mathrm{Ar}}\right), 132.3\left(C_{\mathrm{Ar}}\right), 130.1\left(C_{\mathrm{Ar}}\right), 130.0\left(C_{\mathrm{Ar}}\right), 129.7\left(C_{\mathrm{Ar}}\right), 128.3\left(C_{\mathrm{Ar}}\right), 127.5\left(C_{\mathrm{Ar}}\right)$, $126.7\left(C_{\mathrm{Ar}}\right), 125.3\left(C_{\mathrm{Ar}}\right), 81.8\left(C_{\mathrm{COD}}\right), 81.1\left(C_{\mathrm{COD}}\right), 52.8\left(C_{\mathrm{COD}}\right), 50.7\left(C_{\mathrm{COD}}\right), 34.2$ $\left(C_{\mathrm{COD}}\right), 32.9\left(C_{\mathrm{COD}}\right), 30.1\left(C_{\mathrm{COD}}\right), 29.8\left(C_{\mathrm{COD}}\right), 29.1\left(C_{\mathrm{COD}}\right), 21.4\left(\mathrm{CH}_{3}\right), 19.6\left(\mathrm{CH}_{3}\right)$, $18.1\left(\mathrm{CH}_{3}\right), 17.7\left(\mathrm{CH}_{3}\right)$. HR-MS $(\mathrm{m} / \mathrm{z}): 1075.6[\mathrm{M}-\mathrm{Cl}]^{2+}$.

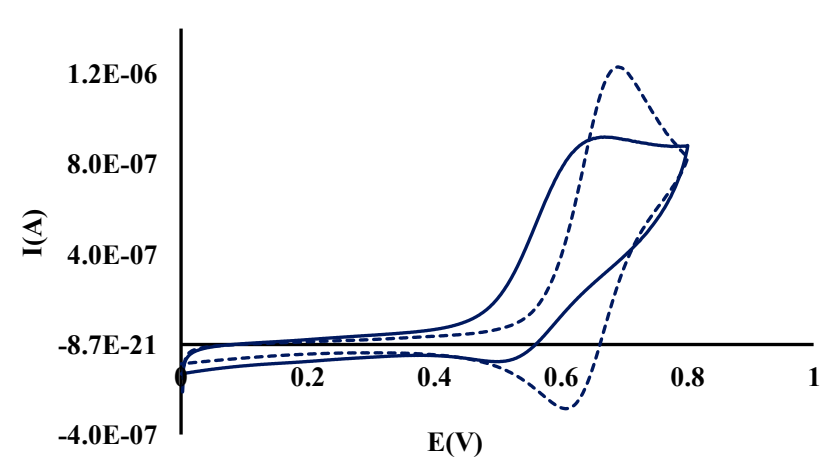

Figure 5.7. $\mathrm{CV}$ plots of complexes $\mathbf{1 C} \mathrm{C}^{\mathrm{Mes}}$ (continuous line), and $\mathbf{2 C ^ { \mathrm { Mes } }}$ (discontinuous line). Experiments carried out using $1 \mathrm{mM}$ solutions of the complexes in dry $\mathrm{CH}_{2} \mathrm{Cl}_{2}$ with $0.1 \mathrm{M}\left[\mathrm{NBu}_{4}\right]\left[\mathrm{PF}_{6}\right]$ as the supporting electrolyte, $100 \mathrm{mVs}^{-1}$ scan rate, $\mathrm{Fc}^{+} / \mathrm{Fc}$ used as internal standard with $\mathrm{E}_{1 / 2}\left(\mathrm{Fc} / \mathrm{Fc}^{+}\right)=0.44 \mathrm{~V}$ vs. SCE.

\section{Synthesis of $3 C^{\text {Mes }}$}

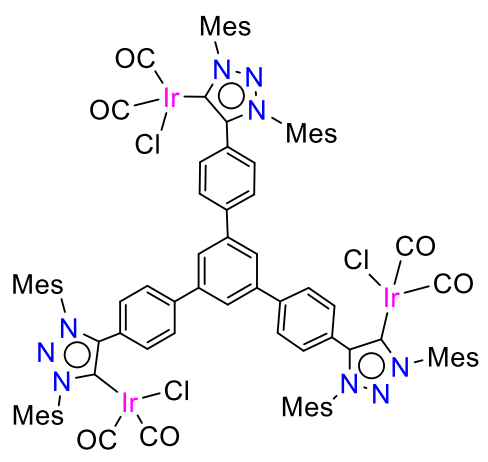

To a solution of $2 \mathrm{C}^{\text {Mes }}(0.050 \mathrm{~g}, 0.02 \mathrm{mmol})$ in dichloromethane $(10 \mathrm{~mL})$ in round a bottomed flask, $\mathrm{CO}$ gas was bubble through at $0{ }^{\circ} \mathrm{C}$ for $30 \mathrm{~min}$. The solution was concentrated under reduced pressure. Addition of hexanes allows to precipitate a yellow solid $0.043 \mathrm{~g}$. Yield: $93 \%$. ${ }^{1} \mathrm{H}$ NMR $\left(300 \mathrm{MHz}, \mathrm{CDCl}_{3}\right): \delta(\mathrm{ppm}) 7.80-$ $7.60\left(\mathrm{~m}, 15 \mathrm{H}, \mathrm{C} H_{\mathrm{Ar}}\right), 7.07-7.04\left(\mathrm{~m}, 12 \mathrm{H}, \mathrm{C} H_{\mathrm{Ar}}\right), 2.41-$ (Ir-CO), 166.0 (Ir-CO), $148.6\left(C_{\mathrm{Ar}}\right), 141.8\left(C_{\mathrm{Ar}}\right), 141.2\left(C_{\mathrm{Ar}}\right), 140.7\left(C_{\mathrm{Ar}}\right), 135.8\left(C_{\mathrm{Ar}}\right)$, $134.5\left(C_{\mathrm{Ar}}\right), 131.4\left(C_{\mathrm{Ar}}\right), 130.3\left(C_{\mathrm{Ar}}\right), 129.8\left(C_{\mathrm{Ar}}\right), 129.3\left(C_{\mathrm{Ar}}\right), 127.0\left(C_{\mathrm{Ar}}\right), 125.8\left(C_{\mathrm{Ar}}\right)$, $125.4\left(\mathrm{C}_{\mathrm{Ar}}\right), 21.3\left(\mathrm{CH}_{3}\right), 18.2\left(\mathrm{CH}_{3}\right), 17.5\left(\mathrm{CH}_{3}\right)$. HR-MS $(\mathrm{m} / \mathrm{z}): 2073.5$ [M$\mathrm{Cl}+\mathrm{MeCN}]^{+}$, IR $\left(\mathrm{cm}^{-1}\right):$ 2057, 1972; TEP: 2042. 


\section{Synthesis of $4 C^{\text {Mes }}$}

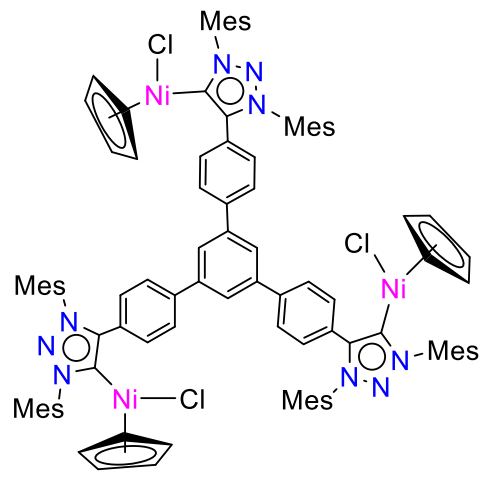

A Schlenk was charged with $\left[\mathbf{H}_{3} \mathbf{C}^{\mathbf{M e s}}\right]\left(\mathbf{P F}_{6}\right)_{3}(0.10 \mathrm{~g}$, $0.06 \mathrm{mmol}), \mathrm{NiCp}_{2}(0.46 \mathrm{~g}, 0.24 \mathrm{mmol})$ and $\mathrm{NEt}_{4} \mathrm{Cl}(0.30$ $\mathrm{g}, 0.18 \mathrm{mmol})$. The resulting mixture was suspended in 1,4-dioxane $(8 \mathrm{~mL})$ and stirred for 10 minutes at room temperature. Then, the reaction was heated to reflux overnight. The solution slowly turned from green to dark red. The crude mixture was cooled to RT and filtered through celite under nitrogen atmosphere. The solvent was removed under reduced pressure and the crude solid was washed with diethyl ether. The desired complex was purified by precipitation from a mixture of $\mathrm{CH}_{2} \mathrm{Cl}_{2} /$ hexane to yield $40 \mathrm{mg}$ of a red solid. Yield: $40 \%$. ${ }^{1} \mathrm{H}$ NMR (400 MHz, $\mathrm{CDCl}_{3}$ ): $\delta$ (ppm) 8.44 (bs, 6H, $\left.\mathrm{CH}_{\mathrm{Ar}}\right), 7.92\left(\mathrm{bs}, 3 \mathrm{H}, \mathrm{C} H_{\mathrm{Ar}}\right), 7.81$ (bs, 9H, $\left.\mathrm{CH} H_{\mathrm{Ar}}\right), 7.18$ (bs, 6H, $\left.\mathrm{C} H_{\mathrm{Ar}}\right), 7.04(\mathrm{bs}, 6 \mathrm{H}$, $\left.\mathrm{CH}_{\mathrm{Ar}}\right), 4.79$ (bs, 15H, CH $\left.H_{\mathrm{Cp}}\right), 2.36$ (bs, 9H, $\left.\mathrm{CH}_{3}\right), 2.23$ (bs, 27H, $\left.\mathrm{CH}_{3}\right), 1.99$ (bs, 18H, $\left.\mathrm{CH}_{3}\right) .{ }^{13} \mathrm{C}\left\{{ }^{1} \mathrm{H}\right\}$ NMR $\left(100 \mathrm{MHz}, \mathrm{CDCl}_{3}\right): \delta(\mathrm{ppm}) 151.4$ (Ni- $\left.C_{\text {carbene }}\right), 148.5\left(C_{\mathrm{Ar}}\right), 141.6$ $\left(C_{\mathrm{Ar}}\right), 141.4\left(C_{\mathrm{Ar}}\right), 140.5\left(C_{\mathrm{Ar}}\right), 137.0\left(C_{\mathrm{Ar}}\right), 135.5\left(C_{\mathrm{Ar}}\right), 134.5\left(C_{\mathrm{Ar}}\right), 134.1\left(C_{\mathrm{Ar}}\right), 132.0$ $\left(C_{\mathrm{Ar}}\right), 130.3\left(C_{\mathrm{Ar}}\right), 129.8\left(C_{\mathrm{Ar}}\right), 129.4\left(C_{\mathrm{Ar}}\right), 127.5\left(C_{\mathrm{Ar}}\right), 127.1\left(C_{\mathrm{Ar}}\right), 125.6\left(C_{\mathrm{Ar}}\right), 125.3$ $\left(C_{\mathrm{Ar}}\right), 92.0\left(\mathrm{CH}_{\mathrm{Cp}}\right), 21.4\left(\mathrm{CH}_{3}\right), 18.3\left(\mathrm{CH}_{3}\right), 17.7\left(\mathrm{CH}_{3}\right)$. HR-MS $(\mathrm{m} / \mathrm{z}): 810.7[\mathrm{M}-2 \mathrm{Cl}]^{2+}$.
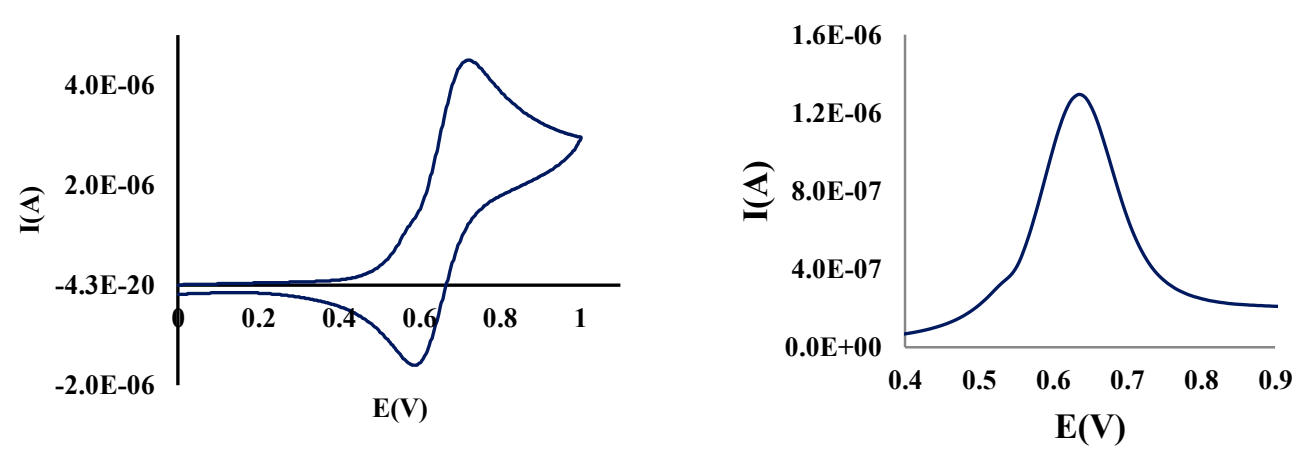

Figure 5.8. $\mathrm{CV}$ plot (left) and relevant DPV section (right) of complex $4 \mathrm{C}^{\mathrm{Mes}}\left(1 \mathrm{mM}\right.$ in dry $\mathrm{CH}_{2} \mathrm{Cl}_{2}$ with $0.1 \mathrm{M}\left[\mathrm{NBu}_{4}\right]\left[\mathrm{PF}_{6}\right]$ as the supporting electrolyte, $50 \mathrm{mVs}^{-1}$ scan rate, $\mathrm{Fc}^{+} / \mathrm{Fc}$ used as internal standard with $\mathrm{E}_{1 / 2}\left(\mathrm{Fc} / \mathrm{Fc}^{+}\right)=0.44 \mathrm{~V}$ vs. SCE $)$. 


\subsubsection{Synthesis and characterization of metal complexes: Chapter 3}

Synthesis of $6 B^{\text {Et }}$

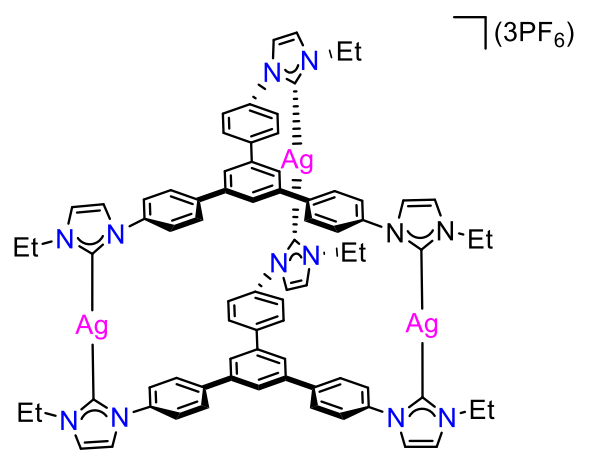

To a mixture of $\left[\mathbf{H}_{3} \mathbf{B}^{\mathrm{Et}}\right]\left(\mathbf{P F}_{\mathbf{6}}\right)_{3} \quad(0.080 \mathrm{~g}, 0.078$ mmol) and $\mathrm{Ag}_{2} \mathrm{O}$ (0.027 g, $\left.0.117 \mathrm{mmol}\right)$ was added acetonitrile $(10 \mathrm{~mL})$. The resulting suspension was heated to $60{ }^{\circ} \mathrm{C}$ for $48 \mathrm{~h}$ under exclusion of light. After cooling of the reaction mixture to ambient temperature, the obtained suspension was filtered through a pad of Celite to get a clear solution. The

filtrate was concentrated to $3 \mathrm{~mL}$ and addition of $15 \mathrm{~mL}$ of diethyl ether resulted in the precipitation of a white solid. The precipitate was filtered off, washed with diethyl ether and dried in vacuo. Yield: $0.058 \mathrm{~g}(76 \%) .{ }^{1} \mathrm{H}$ NMR (400 MHz, DMSO-d6): $\delta(\mathrm{ppm})$ 7.97 (s, 6H, CH $H_{\text {Imid }}$ ), 7.87 (s, 6H, CH $H_{\text {Imid }}$ ), 7.79 (s br, 24H, $\mathrm{C} H_{\mathrm{Ar}}$ ), 7.66 (s, 6H, CH $H_{\mathrm{Ar}}$ ), 4.43 (q, $\left.J=7.3 \mathrm{~Hz}, 12 \mathrm{H}, \mathrm{CH}_{2}\right), 1.60\left(\mathrm{t}, J=7.3 \mathrm{~Hz}, 18 \mathrm{H}, \mathrm{CH}_{3}\right) .{ }^{13} \mathrm{C}\left\{{ }^{1} \mathrm{H}\right\}$ NMR $(100$ $\left.\mathrm{MHz}, \mathrm{DMSO}-d_{6}\right): \delta(\mathrm{ppm}) \delta 178.3\left(\mathrm{Ag}-C_{\text {carbene }}\right), 138.8\left(C_{\mathrm{Ar}}\right), 138.6\left(C_{\mathrm{Ar}}\right), 138.5\left(C_{\mathrm{Ar}}\right)$, $127.2\left(C_{\mathrm{Ar}}\right), 123.5\left(C_{\mathrm{Ar}}\right), 122.8\left(C_{\mathrm{Ar}}\right), 122.7\left(C_{\text {Imid }}\right), 122.0\left(C_{\text {Imid }}\right), 46.8\left(C_{2}\right), 16.9$ $\left(\mathrm{CH}_{3}\right)$. HR-MS $(\mathrm{m} / \mathrm{z}): 500.4[\mathrm{M}]^{3+}, 823.1\left[\mathrm{MPF}_{6}\right]^{2+}$.

\section{Synthesis of $7 B^{E t}$}

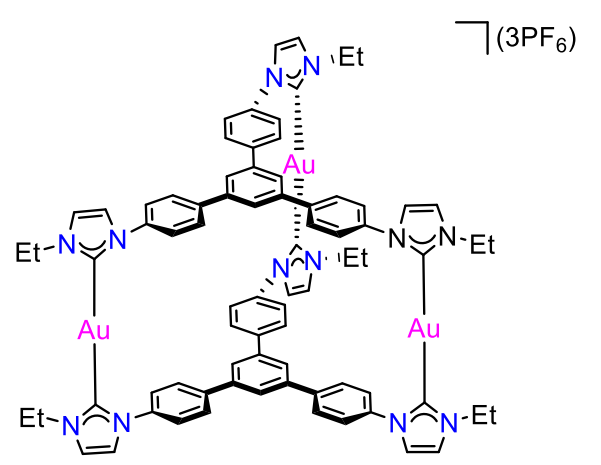

To a solution of $\left[\mathbf{H}_{3} \mathbf{B}^{\mathrm{Et}}\right]\left(\mathbf{P F}_{\mathbf{6}}\right)_{3}(0.058 \mathrm{~g}, 0.030$ mmol) in acetonitrile $(5 \mathrm{~mL})$ was added solid $\left[\mathrm{AuCl}\left(\mathrm{SMe}_{2}\right)\right](0.027 \mathrm{~g}, 0.092 \mathrm{mmol})$. Immediately after the addition a white solid started to precipitate. The reaction mixture was left stirring at ambient temperature for $16 \mathrm{~h}$ and was then slowly filtered through a pad of Celite until a clear filtrate was obtained. The filtrate was added slowly to diethyl ether $(20 \mathrm{~mL})$ to get a white solid which was collected by filtration, washed with diethyl ether and dried in vacuo. Yield: 0.046 g (70\%). ${ }^{1} \mathrm{H}$ NMR (400 MHz, DMSO- $\left.d_{6}\right): \delta$ (ppm) 7.96 (s, 6H, CH $H_{\text {Imid }}$ ), 7.90 (s, $\left.6 \mathrm{H}, \mathrm{C} H_{\text {Imid }}\right), 7.84\left(\mathrm{~d}, J=8.3 \mathrm{~Hz}, 12 \mathrm{H}, \mathrm{CH}_{\mathrm{Ar}}\right), 7.77\left(\mathrm{~d}, J=8.3 \mathrm{~Hz}, 12 \mathrm{H}, \mathrm{C} H_{\mathrm{Ar}}\right), 7.71(\mathrm{~s}$, $\left.6 \mathrm{H}, \mathrm{C} H_{\mathrm{Ar}}\right), 4.49$ (q, $\left.J=7.3 \mathrm{~Hz}, 12 \mathrm{H}, \mathrm{CH}_{2}\right), 1.63\left(\mathrm{t}, J=7.3 \mathrm{~Hz}, 18 \mathrm{H}, \mathrm{CH}_{3}\right) .{ }^{13} \mathrm{C}\left\{{ }^{1} \mathrm{H}\right\}$ NMR (100 MHz, DMSO- $\left.d_{6}\right): \delta(\mathrm{ppm}) \delta 180.6$ (Au- $\left.C_{\text {carbene }}\right), 138.7\left(C_{\mathrm{Ar}}\right), 138.4\left(C_{\mathrm{Ar}}\right)$, $137.9\left(C_{\mathrm{Ar}}\right), 126.9\left(C_{\mathrm{Ar}}\right), 124.4\left(C_{\mathrm{Ar}}\right), 122.8\left(C_{\mathrm{Imid}}\right), 122.7\left(C_{\text {Imid }}\right), 46.4\left(\mathrm{CH}_{2}\right), 16.7$ $\left(\mathrm{CH}_{3}\right)$. HR-MS $(\mathrm{m} / \mathrm{z}): 589.1[\mathrm{M}]^{3+}, 956.2\left[\mathrm{MPF}_{6}\right]^{2+}$. 


\section{Synthesis of $8 B^{E t}$}

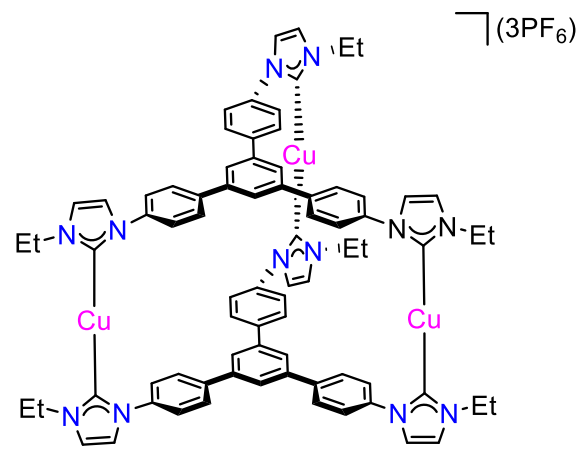

A sample of $\left[\mathbf{H}_{3} \mathbf{B}^{\mathrm{Et}}\right]\left(\mathbf{P F}_{\mathbf{6}}\right)_{3}(0.058 \mathrm{~g}, 0.030 \mathrm{mmol})$ was dissolved in $10 \mathrm{~mL}$ of acetonitrile and to this solution was added solid $\mathrm{CuI}(0.018 \mathrm{~g}, 0.095$ mmol). The reaction mixture was stirred for $16 \mathrm{~h}$ at ambient temperature. The resulting suspension was slowly filtered through a pad of Celite to get a clear solution. The filtrate was concentrated to $2 \mathrm{~mL}$ and addition of $10 \mathrm{~mL}$ diethyl ether resulted in the precipitation of a white solid. The white solid was filtered off, washed with diethyl ether and dried in vacuo. Yield: $0.034 \mathrm{~g}$ (63\%). ${ }^{1} \mathrm{H}$ NMR (200 MHz, DMSO-d $)_{6}$ : $\delta$ (ppm) 7.98 (s, 6H, CH $\left.H_{\text {Imid }}\right), 7.83$ (s, 6H, $\left.\mathrm{CH}_{\text {Imid }}\right), 7.78$ (s, 24H, CHAr), 7.64 (s, 6H, CHAr), 4.45 (q, J = 7.2 Hz, 12H, CH2), 1.61 (t, $\left.J=7.2 \mathrm{~Hz}, 18 \mathrm{H}, \mathrm{CH}_{3}\right) \cdot{ }^{13} \mathrm{C}\left\{{ }^{1} \mathrm{H}\right\} \mathrm{NMR}\left(50 \mathrm{MHz}, \mathrm{DMSO}-d_{6}\right): \delta(\mathrm{ppm}) \delta 174.3(\mathrm{Cu}-$ $\left.C_{\text {carbene }}\right), 137.9\left(C_{\mathrm{Ar}}\right), 137.3\left(C_{\mathrm{Ar}}\right), 126.1\left(C_{\mathrm{Ar}}\right), 126.1\left(C_{\mathrm{Ar}}\right), 122.3\left(C_{\mathrm{Ar}}\right), 121.9\left(C_{\mathrm{Ar}}\right)$, $121.5\left(C_{\text {Imid }}\right), 120.6\left(C_{\text {Imid }}\right), 45.9\left(\mathrm{CH}_{2}\right), 16.4\left(\mathrm{CH}_{3}\right)$. HR-MS $(\mathrm{m} / z): 455.8[\mathrm{M}]^{3+}$.

\section{Synthesis of $5 C^{\text {Mes }}$}

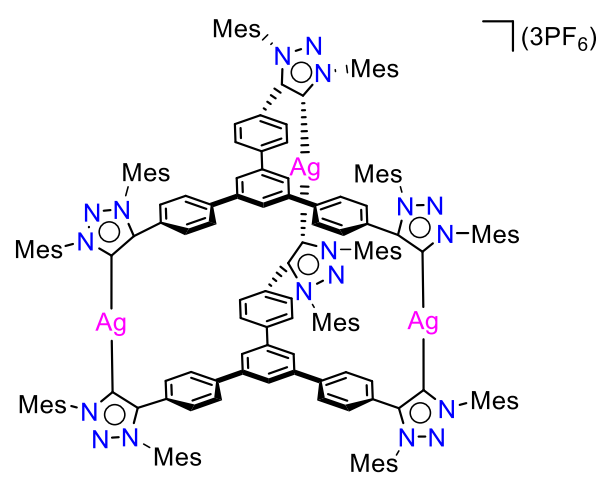

A mixture of $\left[\mathbf{H}_{3} \mathbf{C}^{\mathrm{Mes}}\right]\left(\mathbf{P F}_{\mathbf{6}}\right)_{3} \quad(100 \mathrm{mg}, 0.085$ mmol) and $\mathrm{Ag}_{2} \mathrm{O}(30 \mathrm{mg}, 0.13 \mathrm{mmol})$ in $\mathrm{MeOH}(7$ $\mathrm{mL}$ ) was heated at $60{ }^{\circ} \mathrm{C}$ overnight under exclusion of light. After cooling the reaction mixture to room temperature, the suspension was filtered through a pad of Celite, washed with $\mathrm{CH}_{2} \mathrm{Cl}_{2}$ to yield a clear solution, which was concentrated to dryness yielding a white solid. (yield: $114 \mathrm{mg}$. 42\%). ${ }^{1} \mathrm{H}$ NMR (300 $\left.\mathrm{MHz}, \mathrm{CD}_{2} \mathrm{Cl}_{2}\right): \delta(\mathrm{ppm})$ 7.53-7.35 (m, 30H, $\mathrm{CH}_{\mathrm{Ar}}$ ), 7.06-7.00 (m, 24H, $\left.\mathrm{CH}_{\mathrm{Ar}}\right), 2.54$ (bs, $\left.18 \mathrm{H}, \mathrm{CH}_{3}\right), 2.34$ (bs, $\left.18 \mathrm{H}, \mathrm{CH}_{3}\right) \cdot{ }^{13} \mathrm{C}\left\{{ }^{1} \mathrm{H}\right\} \mathrm{NMR}\left(75 \mathrm{MHz}, \mathrm{CD}_{2} \mathrm{Cl}_{2}\right): \delta(\mathrm{ppm}) 169.7$ (dd, $\left.J\left(\mathrm{C}-\mathrm{Ag}^{107}\right)=165.0 \mathrm{~Hz}, J\left(\mathrm{C}-\mathrm{Ag}^{109}\right)=190.5 \mathrm{~Hz}, C_{\text {carbene }}\right), 150.3\left(C_{\mathrm{Ar}}\right), 150.1\left(C_{\mathrm{Ar}}\right), 142.6$ $\left(C_{\mathrm{Ar}}\right), 141.2\left(C_{\mathrm{Ar}}\right), 141.0\left(C_{\mathrm{Ar}}\right), 139.8\left(C_{\mathrm{Ar}}\right), 136.2\left(C_{\mathrm{Ar}}\right), 134.3\left(C_{\mathrm{Ar}}\right), 131.8\left(C_{\mathrm{Ar}}\right), 130.4$ $\left(C_{\mathrm{Ar}}\right), 129.8\left(C_{\mathrm{Ar}}\right), 129.3\left(C_{\mathrm{Ar}}\right), 127.1\left(C_{\mathrm{Ar}}\right), 123.9\left(C_{\mathrm{Ar}}\right), 21.8\left(C_{3}\right), 21.5\left(C_{3}\right), 17.9$ $\left(\mathrm{CH}_{3}\right)$. Electrospray MS $(20 \mathrm{~V}, \mathrm{~m} / \mathrm{z}): 919.2[\mathrm{M}]^{3+}, 1451.2[\mathrm{M}-\mathrm{Cl}]^{2+}$. Elemental analysis calcd (\%) for $\mathrm{C}_{168} \mathrm{H}_{162} \mathrm{~N}_{18} \mathrm{Ag}_{3} \mathrm{P}_{3} \mathrm{~F}_{18}: \mathrm{C}, 63.2 ; \mathrm{H}, 5.1 ; \mathrm{N}, 7.8$ found $\mathrm{C}, 63.4 ; \mathrm{H}, 5.3 ; \mathrm{N}$, 7.3 . 


\section{Synthesis of $6 C^{\text {Mes }}$}

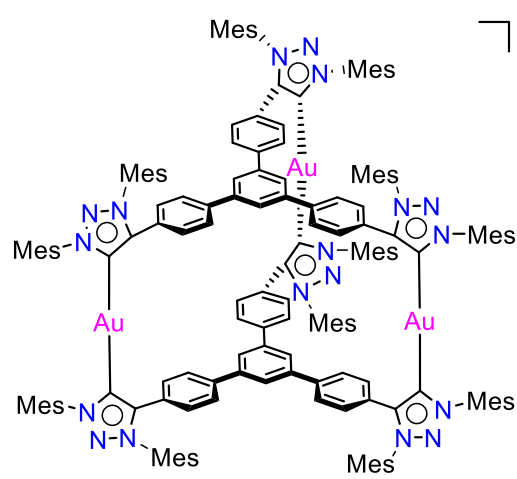

$\neg\left(3 \mathrm{AuCl}_{2}\right) \quad$ A solution of $\mathbf{5 C}$ Mes $(55 \mathrm{mg}, 0.017 \mathrm{mmol})$ and $\left[\mathrm{AuCl}\left(\mathrm{SMe}_{2}\right)\right] \quad(32 \mathrm{mg}, \quad 0.109 \mathrm{mmol})$ in acetonitrile $(8 \mathrm{~mL})$ was stirred at room temperature for 5 days. The resulting suspension was filtered through a pad of Celite, washed with $\mathrm{CH}_{2} \mathrm{Cl}_{2}$ to yield a clear solution, which was concentrated to dryness yielding a white solid.

(yield: $38 \mathrm{mg} .58 \%) .{ }^{1} \mathrm{H}$ NMR $\left(300 \mathrm{MHz}, \mathrm{CD}_{2} \mathrm{Cl}_{2}\right.$ ): $\delta(\mathrm{ppm}) 7.84\left(\mathrm{~s}, 6 \mathrm{H}, \mathrm{C} H_{\mathrm{Ar}}\right.$ ), 7.777.69 (s, 24H, CH $\left.H_{\mathrm{Ar}}\right), 7.14-7.08\left(\mathrm{~m}, 24 \mathrm{H}, \mathrm{CH}_{\mathrm{Ar}}\right), 2.43-2.39\left(\mathrm{~m}, 36 \mathrm{H}, \mathrm{CH}_{3}\right), 2.20(\mathrm{~s}, 36 \mathrm{H}$, $\left.\mathrm{CH}_{3}\right), 2.05\left(\mathrm{~s}, 36 \mathrm{H}, \mathrm{CH}_{3}\right) .{ }^{13} \mathrm{C}\left\{{ }^{1} \mathrm{H}\right\}$ NMR $\left(75 \mathrm{MHz}, \mathrm{CD}_{2} \mathrm{Cl}_{2}\right): \delta(\mathrm{ppm}) 161.1(\mathrm{dd}, \mathrm{Au}-$ $\left.C_{\text {carbene }}\right), 147.9\left(C_{\mathrm{Ar}}\right), 142.7\left(C_{\mathrm{Ar}}\right), 141.8\left(C_{\mathrm{Ar}}\right), 141.8\left(C_{\mathrm{Ar}}\right), 136.4\left(C_{\mathrm{Ar}}\right), 135.0\left(C_{\mathrm{Ar}}\right)$, $134.8\left(C_{\mathrm{Ar}}\right), 131.8\left(C_{\mathrm{Ar}}\right), 130.5\left(C_{\mathrm{Ar}}\right), 130.0\left(C_{\mathrm{Ar}}\right), 129.6\left(C_{\mathrm{Ar}}\right), 129.6\left(C_{\mathrm{Ar}}\right), 128.1\left(C_{\mathrm{Ar}}\right)$, $126.1\left(C_{\mathrm{Ar}}\right), 21.7\left(\mathrm{CH}_{3}\right), 21.6\left(\mathrm{CH}_{3}\right), 17.9\left(\mathrm{CH}_{3}\right)$. Electrospray MS $(20 \mathrm{~V}, \mathrm{~m} / z): 1008.1$ $[\mathrm{M}]^{3+}, 1645.6\left[\mathrm{MAuCl}_{2}\right]^{2+}$. Elemental analysis calcd (\%) for $\mathrm{C}_{168} \mathrm{H}_{162} \mathrm{~N}_{18} \mathrm{Au}_{3}\left(\mathrm{AuCl}_{2}\right)_{3}$ : C, 52.7; H, 4.3; N, 6.6 found $\mathrm{C}, 53.5 ; \mathrm{H}, 4.7 ; \mathrm{N}, 6.2$.

\section{Synthesis of $\left[1 B^{\text {Et }} C^{M e s}\right]\left(P_{6}\right)_{3}$}

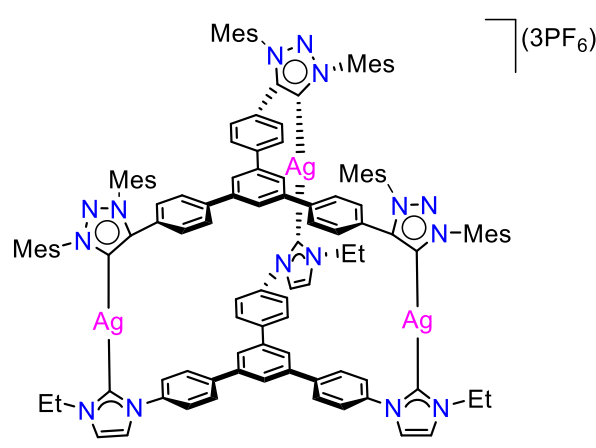

A mixture of $\left[\mathbf{H}_{3} \mathbf{C}^{\mathbf{M e s}}\right]\left(\mathbf{P F}_{\mathbf{6}}\right)_{3}(60 \mathrm{mg}, 0.04 \mathrm{mmol})$, $\left[\mathbf{H}_{3} \mathbf{B}^{\mathrm{Et}}\right]\left(\mathbf{P F}_{6}\right)_{3}$ (42 $\left.\mathrm{mg}, 0.04 \mathrm{mmol}\right)$ and $\mathrm{Ag}_{2} \mathrm{O}(25$ $\mathrm{mg}, 0.11 \mathrm{mmol})$ in $\mathrm{MeOH}(7 \mathrm{~mL})$ was heated to $60{ }^{\circ} \mathrm{C}$ overnight under exclusion of light. The resultimg suspension was filtered through a pad of celite, and washed with $\mathrm{CH}_{2} \mathrm{Cl}_{2}$. Then the filtrate was concentrated to dryness, yielding a white solid (yield: $55 \mathrm{mg}, 43 \%$ ). Method $\boldsymbol{i}$. A mixture of $\mathbf{5 C}^{\text {Mes }}\left(20 \mathrm{mg}, 0.006 \mathrm{mmol}\right.$ ) and $\mathbf{6 B}^{\text {Et }}$ (12 mg, $0.006 \mathrm{mmol})$ in $\mathrm{MeOH}(5 \mathrm{~mL})$ was heated to $60{ }^{\circ} \mathrm{C}$ overnight under exclusion of light. The resulting suspension was filtered through a pad of Celite and washed with $\mathrm{CH}_{2} \mathrm{Cl}_{2}$. The filtrate was concentrated to dryness obtained a white solid (yield: $45 \%$ ). Method ii. A mixture of $\mathbf{5 C}^{\mathrm{Mes}}(30 \mathrm{mg}, 0.015 \mathrm{mmol})$ and $\left[\mathbf{H}_{3} \mathbf{B}^{\mathrm{Et}}\right]\left(\mathbf{P F}_{\mathbf{6}}\right)_{3}(24 \mathrm{mg}, 0.015$ mmol) in $\mathrm{MeOH}(5 \mathrm{~mL})$ was heated to $60^{\circ} \mathrm{C}$ overnight under exclusion of light. The resulting suspension was filtered through a pad of celite and washed with $\mathrm{CH}_{2} \mathrm{Cl}_{2}$. The filtrate was concentrated to dryness obtained a white solid (yield: 55\%). Method iii. A mixture of $\left[\mathbf{H}_{\mathbf{3}} \mathbf{C}^{\mathbf{M e s}}\right]\left(\mathbf{P F}_{\mathbf{6}}\right)_{\mathbf{3}}(30 \mathrm{mg}, 0.009 \mathrm{mmol})$ and $\mathbf{6} \mathbf{B}^{\mathbf{E t}}(10 \mathrm{mg}, 0.009 \mathrm{mmol})$ in $\mathrm{MeOH}(5 \mathrm{~mL})$ was heated to $60{ }^{\circ} \mathrm{C}$ overnight under exclusion of light. The resulting 
suspension was filtered through a pad of celite and washed with $\mathrm{CH}_{2} \mathrm{Cl}_{2}$. The filtrate was concentrated to dryness obtained a white solid (yield: 45\%). ${ }^{1} \mathrm{H}$ NMR (300 MHz, $\left.\mathrm{CD}_{2} \mathrm{Cl}_{2}\right): \delta(\mathrm{ppm})$ 7.65-7.65 (m, 12H, $\left.\mathrm{C} H_{\mathrm{Ar}}\right), 7.55\left(\mathrm{~m}, 6 \mathrm{H}, \mathrm{C} H_{\mathrm{Ar}}\right), 7.46\left(\mathrm{~m}, 12 \mathrm{H}, \mathrm{CH}_{\mathrm{Ar}}\right)$, $7.20\left(\mathrm{~m}, 12 \mathrm{H}, \mathrm{CH} \mathrm{Ar}_{\mathrm{Ar}}\right), 7.06\left(\mathrm{~m}, 6 \mathrm{H}, \mathrm{CH} \mathrm{Ar}_{\mathrm{Ar}}\right), 3.72\left(\mathrm{~m}, 6 \mathrm{H}, \mathrm{CH}_{2}\right), 2.47$ (s, 9H, $\left.\mathrm{CH}_{3}\right), 2.34$ (s, $\left.9 \mathrm{H}, \mathrm{CH}_{3}\right), 2.24\left(\mathrm{~s}, 18 \mathrm{H}, \mathrm{CH}_{3}\right), 2.05\left(\mathrm{~s}, 9 \mathrm{H}, \mathrm{CH}_{3}\right), 2.02\left(\mathrm{~s}, 18 \mathrm{H}, \mathrm{CH}_{3}\right) .{ }^{13} \mathrm{C}\left\{{ }^{1} \mathrm{H}\right\} \mathrm{NMR}(75$ $\left.\mathrm{MHz}, \mathrm{CD}_{2} \mathrm{Cl}_{2}\right): \delta(\mathrm{ppm}) 180.9-178.1\left(\mathrm{dd}, J\left(\mathrm{C}-\mathrm{Ag}^{107}\right)=179.6 \mathrm{~Hz}, J\left(\mathrm{C}-\mathrm{Ag}^{109}\right)=179.4\right.$ $\left.\mathrm{Hz}, C_{\text {carbene }}\right), 170.8-168.3\left(\mathrm{dd}, J\left(\mathrm{C}-\mathrm{Ag}^{107}\right)=169.6 \mathrm{~Hz}, J\left(\mathrm{C}-\mathrm{Ag}^{109}\right)=169.6 \mathrm{~Hz}, C_{\text {carbene }}\right)$, $150.2\left(C_{\mathrm{Ar}}\right), 150.0\left(C_{\mathrm{Ar}}\right), 142.5\left(C_{\mathrm{Ar}}\right), 141.9\left(C_{\mathrm{Ar}}\right), 141.6\left(C_{\mathrm{Ar}}\right), 141.0\left(C_{\mathrm{Ar}}\right), 140.6\left(C_{\mathrm{Ar}}\right)$, $139.8\left(C_{\mathrm{Ar}}\right), 137.3\left(C_{\mathrm{Ar}}\right), 134.9\left(C_{\mathrm{Ar}}\right), 134.7\left(C_{\mathrm{Ar}}\right), 131.5\left(C_{\mathrm{Ar}}\right), 130.3\left(C_{\mathrm{Ar}}\right), 129.8\left(C_{\mathrm{Ar}}\right)$, $129.0\left(C_{\mathrm{Ar}}\right), 128.7\left(C_{\mathrm{Ar}}\right), 127.7\left(C_{\mathrm{Ar}}\right), 126.5\left(C_{\mathrm{Ar}}\right), 124.7\left(C_{\mathrm{Ar}}\right), 122.6\left(C_{\mathrm{Ar}}\right), 122.6\left(C_{\mathrm{Ar}}\right)$, $122.0\left(C_{\mathrm{Ar}}\right), 46.6\left(\mathrm{CH}_{2}\right), 21.4\left(\mathrm{CH}_{3}\right), 21.3\left(\mathrm{CH}_{3}\right), 17.7\left(\mathrm{CH}_{3}\right), 17.6\left(\mathrm{CH}_{3}\right), 17.1\left(\mathrm{CH}_{3}\right)$. Electrospray MS $(20 \mathrm{~V}, \mathrm{~m} / z): 709.5[\mathrm{M}]^{3+}, 1136.8\left[\mathrm{MPF}_{6}\right]^{2+}$. Elemental analysis calcd (\%) for $\mathrm{C}_{123} \mathrm{H}_{117} \mathrm{~N}_{15} \mathrm{Ag}_{3} \mathrm{P}_{3} \mathrm{~F}_{18}: \mathrm{C}, 57.6 ; \mathrm{H}, 4.6 ; \mathrm{N}, 8.2$ found $\mathrm{C}, 57.0 ; \mathrm{H}, 7.7 ; \mathrm{N}, 7.5$.

\subsubsection{Synthesis and characterization of metal complexes: Chapter 4} Synthesis of $1 \mathrm{G}^{n \mathrm{Bu}}$

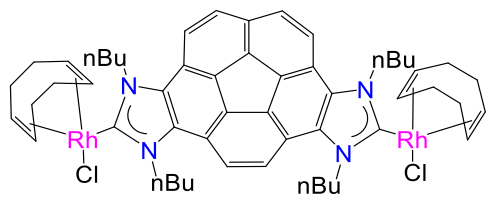

A Schlenk flask was loaded with $\left[\mathbf{H}_{2} \mathbf{G}^{n \mathbf{B u}}\right]\left(\mathbf{P F}_{\mathbf{6}}\right)_{2}(0.1 \mathrm{~g}$, $0.12 \mathrm{mmol}),[\mathrm{RhCl}(\mathrm{COD})]_{2}(0.58 \mathrm{~g}, 0.12 \mathrm{mmol})$ and $\mathrm{K}_{2} \mathrm{CO}_{3}(0.1 \mathrm{~g}, 0.34 \mathrm{mmol})$. The mixture was suspended in acetone $(10 \mathrm{~mL})$ and stirred for $12 \mathrm{~h}$ at $60{ }^{\circ} \mathrm{C}$. The resulting solid was filtered and washed several times with acetone. The crude mixture was dissolved in $\mathrm{CH}_{2} \mathrm{Cl}_{2}$ and purified by filtration through a pad of Celite. The resulting solution was concentrated to dryness obtained $28 \mathrm{mg}$ of a yellow solid. Yield: $23 \%{ }^{1} \mathrm{H}$ NMR (500 MHz, $\left.\mathrm{CDCl}_{3}\right): \delta(\mathrm{ppm}) 8.17\left(\mathrm{~s}, 2 \mathrm{H}, \mathrm{CH}_{\mathrm{Ar}}\right), 8.04\left(\mathrm{~m}, 4 \mathrm{H}, \mathrm{CH} \mathrm{Ar}_{\mathrm{Ar}}\right), 5.46(\mathrm{~m}, 4 \mathrm{H}$, $\left.\mathrm{CH}_{\mathrm{COD}}\right), 5.24\left(\mathrm{~m}, 8 \mathrm{H}, \mathrm{NCH}_{2} \mathrm{CH}_{2} \mathrm{CH}_{2} \mathrm{CH}_{3}\right), 3.49\left(\mathrm{~m}, 4 \mathrm{H}, \mathrm{CH} H_{\mathrm{COD}}\right), 2.52(\mathrm{~m}, 12 \mathrm{H}$, $\left.\mathrm{CH}_{\mathrm{COD}}\right), 2.18(\mathrm{~m}, 4 \mathrm{H}, \mathrm{CH}$ COD $), 2.05\left(\mathrm{~m}, 8 \mathrm{H}, \mathrm{NCH}_{2} \mathrm{CH}_{2} \mathrm{CH}_{2} \mathrm{CH}_{3}\right), 1.83(\mathrm{~m}, 8 \mathrm{H}$, $\left.\mathrm{NCH}_{2} \mathrm{CH}_{2} \mathrm{CH}_{2} \mathrm{CH}_{3}\right), 1.24\left(\mathrm{~m}, 12 \mathrm{H}, \mathrm{NCH}_{2} \mathrm{CH}_{2} \mathrm{CH}_{2} \mathrm{CH}_{3}\right) .{ }^{13} \mathrm{C}\left\{{ }^{1} \mathrm{H}\right\} \mathrm{NMR}(126 \mathrm{MHz}$, $\left.\mathrm{CDCl}_{3}\right): \delta(\mathrm{ppm}) 190.5\left(\mathrm{~d}, J=52 \mathrm{~Hz}, \mathrm{Rh}-C_{\text {Carbene }}\right), 133.5\left(C_{\mathrm{Ar}}\right), 131.5\left(C_{\mathrm{Ar}}\right), 131.4\left(C_{\mathrm{Ar}}\right)$, $130.6\left(C_{\mathrm{Ar}}\right), 128.7\left(C_{\mathrm{Ar}}\right), 128.1\left(C_{\mathrm{Ar}}\right), 123.9\left(C_{\mathrm{Ar}}\right), 122.8\left(C_{\mathrm{Ar}}\right), 119.5\left(C_{\mathrm{Ar}}\right), 117.9\left(C_{\mathrm{Ar}}\right)$, $99.9\left(C_{\mathrm{COD}}\right), 69.1\left(C_{\mathrm{COD}}\right), 51.6\left(\mathrm{NCH}_{2} \mathrm{CH}_{2} \mathrm{CH}_{2} \mathrm{CH}_{3}\right), 33.4\left(\mathrm{NCH}_{2} \mathrm{CH}_{2} \mathrm{CH}_{2} \mathrm{CH}_{3}\right), 32.2$ $\left(C_{\mathrm{COD}}\right), \quad 32.1$ (C C $\left.\mathrm{COD}\right), 29.3 \quad\left(\mathrm{NCH}_{2} \mathrm{CH}_{2} \mathrm{CH}_{2} \mathrm{CH}_{3}\right), 21.0 \quad\left(\mathrm{NCH}_{2} \mathrm{CH}_{2} \mathrm{CH}_{2} \mathrm{CH}_{3}\right), \quad 14.3$ $\left(\mathrm{NCH}_{2} \mathrm{CH}_{2} \mathrm{CH}_{2} \mathrm{CH}_{3}\right)$. HRMS ESI-TOF-MS (positive mode): 1011.3090 [M-Cl] ${ }^{+}$ 

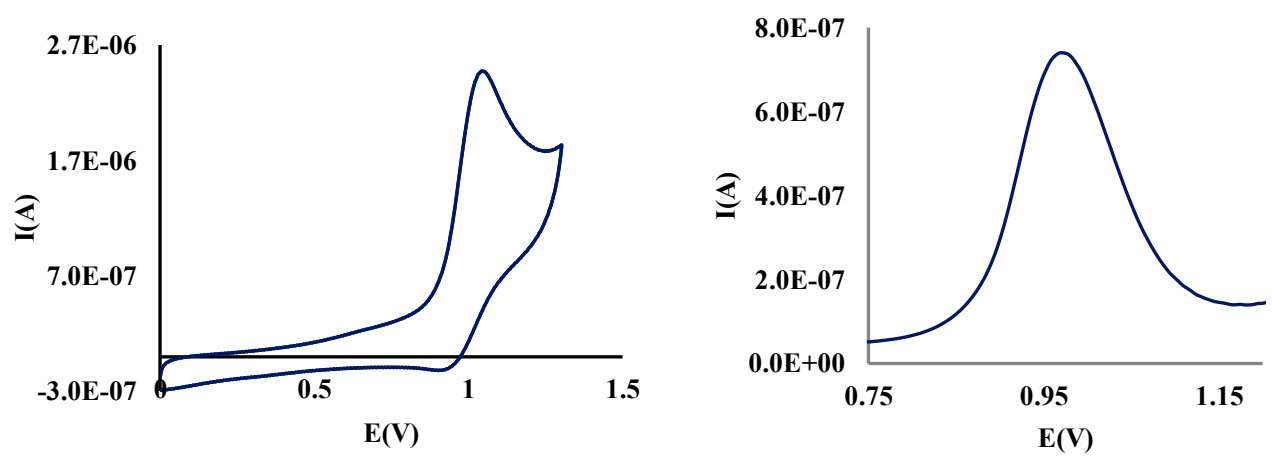

Figure 5.9. CV plot (left) and relevant DPV section (right) of complex $\mathbf{1 G}^{n \mathbf{B u}}\left(1 \mathrm{mM}\right.$ in dry $\mathrm{CH}_{2} \mathrm{Cl}_{2}$ with $0.1 \mathrm{M}\left[\mathrm{NBu}_{4}\right]\left[\mathrm{PF}_{6}\right]$ as the supporting electrolyte, $50 \mathrm{mVs}^{-1}$ scan rate, $\mathrm{Fc}^{+} / \mathrm{Fc}$ used as internal standard with $\mathrm{E}_{1 / 2}\left(\mathrm{Fc} / \mathrm{Fc}^{+}\right)=0.44 \mathrm{~V}$ vs. SCE $)$.

\section{Synthesis of $2 \mathrm{G}^{n \mathrm{Bu}}$}

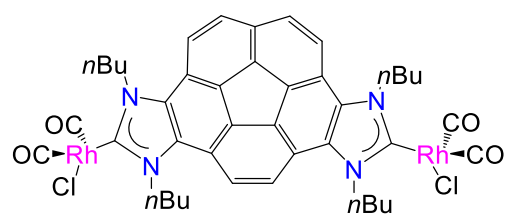

To a solution of $\mathbf{1 G}^{\boldsymbol{n} \mathbf{B u}}$ in dichloromethane $(10 \mathrm{~mL})$ in round a bottomed flask, $\mathrm{CO}$ gas was bubble through at 0 ${ }^{\circ} \mathrm{C}$ for $2 \mathrm{~h}$. The solution was concentrated under reduced pressure. Addition of hexanes allows to precipitate a yellow solid. Yield: $85 \%$. ${ }^{1} \mathrm{H}$ NMR $\left(500 \mathrm{MHz}, \mathrm{CDCl}_{3}\right): \delta(\mathrm{ppm})$ 8.25-8.02 (m, 6H, $\mathrm{CH}_{\mathrm{Ar}}$ ), 5.30-4.96 (m, 8H, $\left.\mathrm{NCH}_{2} \mathrm{CH}_{2} \mathrm{CH}_{2} \mathrm{CH}_{3}\right), 2.33-2.20\left(\mathrm{~m}, 8 \mathrm{H}, \mathrm{NCH}_{2} \mathrm{CH}_{2} \mathrm{CH}_{2} \mathrm{CH}_{3}\right)$, $1.74\left(\mathrm{~m}, 8 \mathrm{H}, \mathrm{NCH}_{2} \mathrm{CH}_{2} \mathrm{CH}_{2} \mathrm{CH}_{3}\right), 1.16\left(\mathrm{~m}, 12 \mathrm{H}, \mathrm{NCH}_{2} \mathrm{CH}_{2} \mathrm{CH}_{2} \mathrm{CH}_{3}\right) .{ }^{13} \mathrm{C}\left\{{ }^{1} \mathrm{H}\right\} \mathrm{NMR}$ $\left(126 \mathrm{MHz}, \mathrm{CDCl}_{3}\right): \delta(\mathrm{ppm}) 185.6\left(\mathrm{~d}, J=54 \mathrm{~Hz}, \mathrm{Rh}-C_{\text {Carbene }}\right), 182.6(\mathrm{~d}, J=74 \mathrm{~Hz}, \mathrm{Rh}-$ $\left.C_{\mathrm{CO}}\right), 180.2\left(\mathrm{~d}, J=78 \mathrm{~Hz}, \mathrm{Rh}-C_{\mathrm{CO}}\right), 131.0-117.0\left(C_{\mathrm{Ar}}\right), 51.4\left(\mathrm{NCH}_{2} \mathrm{CH}_{2} \mathrm{CH}_{2} \mathrm{CH}_{3}\right), 31.6$ $\left(\mathrm{NCH}_{2} \mathrm{CH}_{2} \mathrm{CH}_{2} \mathrm{CH}_{3}\right), \quad 29.6\left(\mathrm{NCH}_{2} \mathrm{CH}_{2} \mathrm{CH}_{2} \mathrm{CH}_{3}\right), \quad 27.9 \quad\left(\mathrm{NCH}_{2} \mathrm{CH}_{2} \mathrm{CH}_{2} \mathrm{CH}_{3}\right), \quad 20.2$ $\left(\mathrm{NCH}_{2} \mathrm{CH}_{2} \mathrm{CH}_{2} \mathrm{CH}_{3}\right), 13.9\left(\mathrm{NCH}_{2} \mathrm{CH}_{2} \mathrm{CH}_{2} \mathrm{CH}_{3}\right)$; IR ( $\left.\mathrm{cm}^{-1}\right)$ : 2083, 2003; TEP: 2055.

\section{Synthesis of $3 G^{t B u}$}

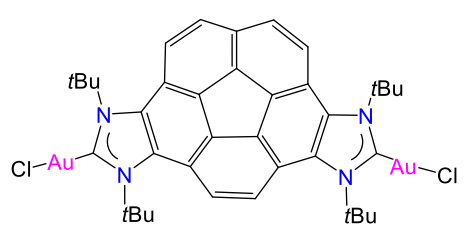

To a flame dried Schlenk containing a suspension of compound $\left[\mathbf{H}_{\mathbf{2}} \mathbf{G}^{\boldsymbol{t} \mathbf{B u}}\right]\left(\mathbf{P F}_{\mathbf{6}}\right)_{2}(50 \mathrm{mg}, 0.06 \mathrm{mmol})$ in dry THF $(8 \mathrm{~mL})$ at $-78{ }^{\circ} \mathrm{C}$, KHMDS $(0.5 \mathrm{M}$ in toluene, $260 \mu \mathrm{L}$, $0.130 \mathrm{mmol}$ ) was added dropwise. The mixture was stirred for $15 \mathrm{~min}$ at $-78^{\circ} \mathrm{C}$, then the resulting solution was transferred via oven-dried cannula to a second flame dried Schlenk containing a suspension of [ $\left.\mathrm{Au}\left(\mathrm{SMe}_{2}\right) \mathrm{Cl}\right](35 \mathrm{mg}, 0.12$ mmol) in THF $(5 \mathrm{~mL})$ stirred at $-78{ }^{\circ} \mathrm{C}$. The resulting solution was kept in the dark, allowed to warm up and stirred overnight. Then, the solvent was removed under vacuum. The crude mixture was dissolved in $\mathrm{CH}_{2} \mathrm{Cl}_{2}$ and stirred with activated charcoal for $30 \mathrm{~min}$. The suspension was filtered through a pad of Celite. The resulting solution was concentrated and a mixture of diethyl ether/hexane was added to yield a white solid 
precipitated. Yield: $37 \mathrm{mg}$ (31\%). ${ }^{1} \mathrm{H}$ NMR (300 MHz, $\left.\mathrm{CD}_{2} \mathrm{Cl}_{2}\right): \delta(\mathrm{ppm}) 8.47(\mathrm{~s}, 2 \mathrm{H}$, $\left.\mathrm{C}_{\mathrm{Ar}}\right), 8.44\left(\mathrm{~d}, J=9.0 \mathrm{~Hz}, 2 \mathrm{H}, \mathrm{C} H_{\mathrm{Ar}}\right), 8.05\left(\mathrm{~d}, J=9.0 \mathrm{~Hz}, 2 \mathrm{H}, \mathrm{C} H_{\mathrm{Ar}}\right), 2.43(\mathrm{~m}, 36 \mathrm{H}$, $\left.\mathrm{NC}\left(\mathrm{CH}_{3}\right)_{3}\right) .{ }^{13} \mathrm{C}\left\{{ }^{1} \mathrm{H}\right\} \mathrm{NMR}\left(75 \mathrm{MHz}, \mathrm{CD}_{2} \mathrm{Cl}_{2}\right): \delta(\mathrm{ppm}) 178.7$ (Au- $\left.\mathrm{C}_{\text {Carbene }}\right), 133.6\left(\mathrm{C}_{\mathrm{Ar}}\right)$, $133.2\left(C_{\mathrm{Ar}}\right), 132.7\left(C_{\mathrm{Ar}}\right), 131.9\left(C_{\mathrm{Ar}}\right), 129.0\left(C_{\mathrm{Ar}}\right), 128.7\left(C_{\mathrm{Ar}}\right), 128.5\left(C_{\mathrm{Ar}}\right), 127.9\left(C_{\mathrm{Ar}}\right)$,

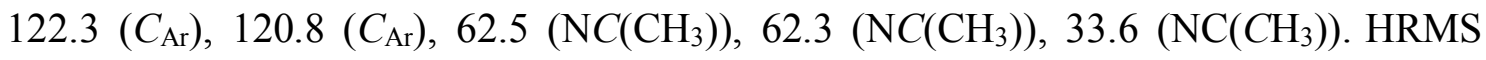
ESI-TOF-MS (positive mode): $787.3[\mathrm{M}-\mathrm{AuCl}+\mathrm{H}]^{+} ; 1041.3[\mathrm{M}+\mathrm{Na}]^{+}$. Elemental analysis calcd (\%) for $\mathrm{C}_{38} \mathrm{H}_{42} \mathrm{~N}_{4} \mathrm{Au}_{2} \mathrm{Cl}_{2} .3 \mathrm{CH}_{2} \mathrm{Cl}_{2}$ : C, 38.6; $\mathrm{H}, 3.8 ; \mathrm{N}$, 4.4; found $\mathrm{C}, 38.6$; $\mathrm{H}, 3.7 ; \mathrm{N}, 4.9$.

\subsection{Catalytic experiments: Chapter 2 and 4}

\section{Addition of Aryl Boronic Acids to Acids to Cyclohex-2-enone}

In a $50 \mathrm{~mL}$ high-pressure Schlenk tube, catalyst (0.2-0.02 mol \%), 2-cyclohexen-1-one (0.5 mmol), arylboronic acid $(0.6 \mathrm{mmol}), \mathrm{KOH}(0.09 \mathrm{mmol})$ and dry toluene $(2 \mathrm{~mL})$ were added. The mixture was stirred and heated at $100{ }^{\circ} \mathrm{C}$ for $6 \mathrm{~h}$. The yields of the reaction were calculated by GC using anisole and 2,4,6-trimethylphenol as internal standard.

\section{Hydroamination of Phenylacetylene with Aryl Amines}

The $\mathrm{Au}^{\mathrm{I}}$ catalyst $\left(0.5 \mathrm{~mol} \%\right.$ based on metal) and $\mathrm{AgBF}_{4}(1 \mathrm{~mol} \%, 0.01 \mathrm{mmol})$ were placed together in a thick-walled Schlenk tube fitted with a Teflon cap. The tube was then evacuated and filled with nitrogen three times. Afterward, $1 \mathrm{~mL}$ of $\mathrm{CH}_{3} \mathrm{CN}$ was added, and the reaction mixture was stirred at room temperature for $5 \mathrm{~min}$. After this time, the corresponding arylamine $(0.55 \mathrm{mmol})$, phenylacetylene $(0.5 \mathrm{mmol})$, and anisole as internal reference $(0.5 \mathrm{mmol})$ were subsequently added. The resulting mixture was stirred at $90{ }^{\circ} \mathrm{C}$ for the appropriate time. The evolution of the reactions, yields, and conversions were determined by GC analysis. The products were identified by comparison to previously reported data. ${ }^{[8]}$

\section{Cyclization of 2,5-Dimethylfuran with Different Terminal Alkynes}

A solution of the alkyne $(1 \mathrm{mmol}), 2,5$-dimethylfuran $(2 \mathrm{mmol})$, the $\mathrm{Au}^{\mathrm{I}}$ catalyst $(1.5$ mol \%), and NaBArF (2 mol \%) in dry dichloromethane $(2.5 \mathrm{~mL})$ was stirred at room temperature or $40{ }^{\circ} \mathrm{C}$ for $24 \mathrm{~h}$. Then, a drop of trimethylamine was added, and the solvent was removed under vacuum. The crude was purified by flash column chromatography using different gradients of hexane, ethyl acetate, and dichloromethane 
to obtain the desired products. The products were identified by comparison to previously reported data. ${ }^{[9]}$

\subsection{DFT experiments: Chapter 3}

All calculations were carried out in Gaussian 09 ${ }^{[10]}$ (revision D.01) using the M06L functional, ${ }^{[11]}$ tight optimizations, and the ultrafine integration grid (a pruned $(99,590)$ grid). The basis sets, listed by their corresponding Gaussian 09 keyword, included QZVP (with the QZVP ECP as implemented in Gaussian 09) for silver and TZVP ${ }^{[12]}$ for all other atoms. The following density fitting basis sets were employed: QZVP (silver) and TZVPFit (all other atoms). The polarizable continuum model using the integral equation formalism (IEFPCM) was used for all calculations, with the radii and nonelectrostatic terms of Truhlar and co-workers' SMD solvation model ( $\mathrm{scrf}=\mathrm{smd}) .{ }^{[13]}$ The optimized geometries were verified to have no negative frequencies by frequency calculations, which also provided the enthalpies and free energies reported below. The energies were calculated at $298.15 \mathrm{~K}$, under pressure (275 atm for benzene and $605 \mathrm{~atm}$ for methanol), following the approach of Martin and co-workers. ${ }^{[14]}$

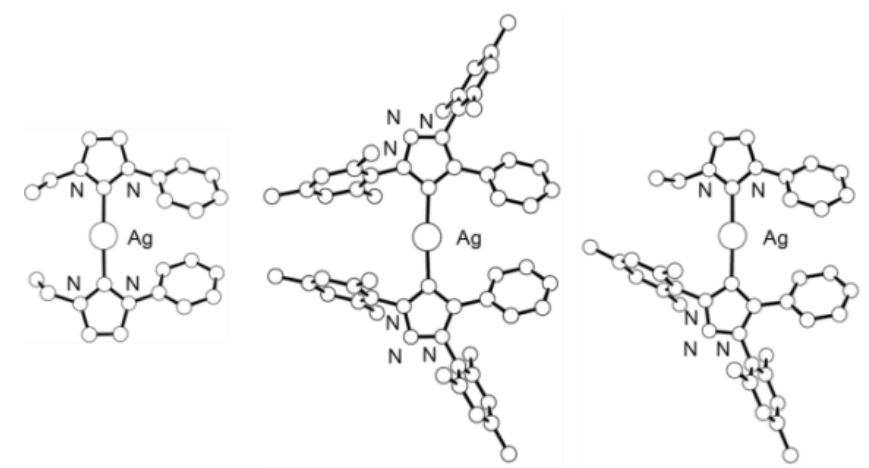

Figure 5.10. Calculated structures of $\left[\mathrm{Ag}(\mathrm{NHC})_{2}\right]^{+},\left[\mathrm{Ag}(\mathrm{MIC})_{2}\right]^{+}$, and $[\mathrm{Ag}(\mathrm{MIC})(\mathrm{NHC})]^{+}$complexes (all hydrogen atoms are omitted for clarity) 
Table 5.1. Calculated energies for the ground-state structures (Hartree)

\begin{tabular}{ccccc}
\hline Compound & Solvent & E & H & G \\
\hline NHC $($ Carbene $)$ & Methanol & -535.958446 & -535.738644 & -535.782130 \\
MIC $($ Carbene $)$ & Methanol & -1171.456758 & -1170.962326 & -1171.042564 \\
{$[\mathrm{Ag}(\mathrm{NHC})]^{+}$} & Methanol & -682.972172 & -682.748679 & -682.798568 \\
{$[\mathrm{Ag}(\mathrm{MIC})]^{+}$} & Methanol & -1318.473701 & -1317.975867 & -1318.062726 \\
{$\left[\mathrm{Ag}(\mathrm{NHC})_{2}\right]^{+}$} & Methanol & -1218.998969 & -1218.553087 & -1218.630025 \\
{$\left[\mathrm{Ag}(\mathrm{NHC})_{2}\right]^{+}$} & Benzene & -1218.985555 & -1218.538735 & -1218.616004 \\
{$\left[\mathrm{Ag}(\mathrm{MIC})_{2}\right]^{+}$} & Methanol & -2490.003772 & -2489.009124 & -2489.161157 \\
{$\left[\mathrm{Ag}(\mathrm{MIC})_{2}\right]^{+}$} & Benzene & -2489.997866 & -2489.001076 & -2489.149935 \\
{$[\mathrm{Ag}(\mathrm{NHC})(\mathrm{MIC})]^{+}$} & Methanol & -1854.501641 & -1853.781108 & -1853.895051 \\
{$[\mathrm{Ag}(\mathrm{NHC})(\mathrm{MIC})]^{+}$} & Benzene & -1854.493038 & -1853.771150 & -1853.885411 \\
\hline
\end{tabular}

\subsection{Titration experiments}

\section{Host-guest studies by ${ }^{1} \mathrm{H}$ NMR titrations with $C_{60}$}

Stock solutions of $\mathbf{3 G}^{t^{\mathbf{B u}}}$ and $\mathrm{C}_{60}$ were prepared in toluene- $d_{8}$ : Solution A) $0.49 \mathrm{mM}$ of $\mathbf{3 G}^{\mathbf{t} \mathbf{B u}}$ and solution B) $2 \mathrm{mM}$ of $\mathrm{C}_{60}$ and $0.49 \mathrm{mM}^{\mathbf{B}} \mathbf{3 G}^{\mathbf{t} \mathbf{B u}}$. Solution A was placed in a NMR tube and aliquots of solution B were added. The concentration of host $\mathbf{3 G}^{\boldsymbol{t} \mathbf{B u}}$ was maintained constant throughout the titration. ${ }^{1} \mathrm{H}$ NMR spectra were directly recorded after each addition. 

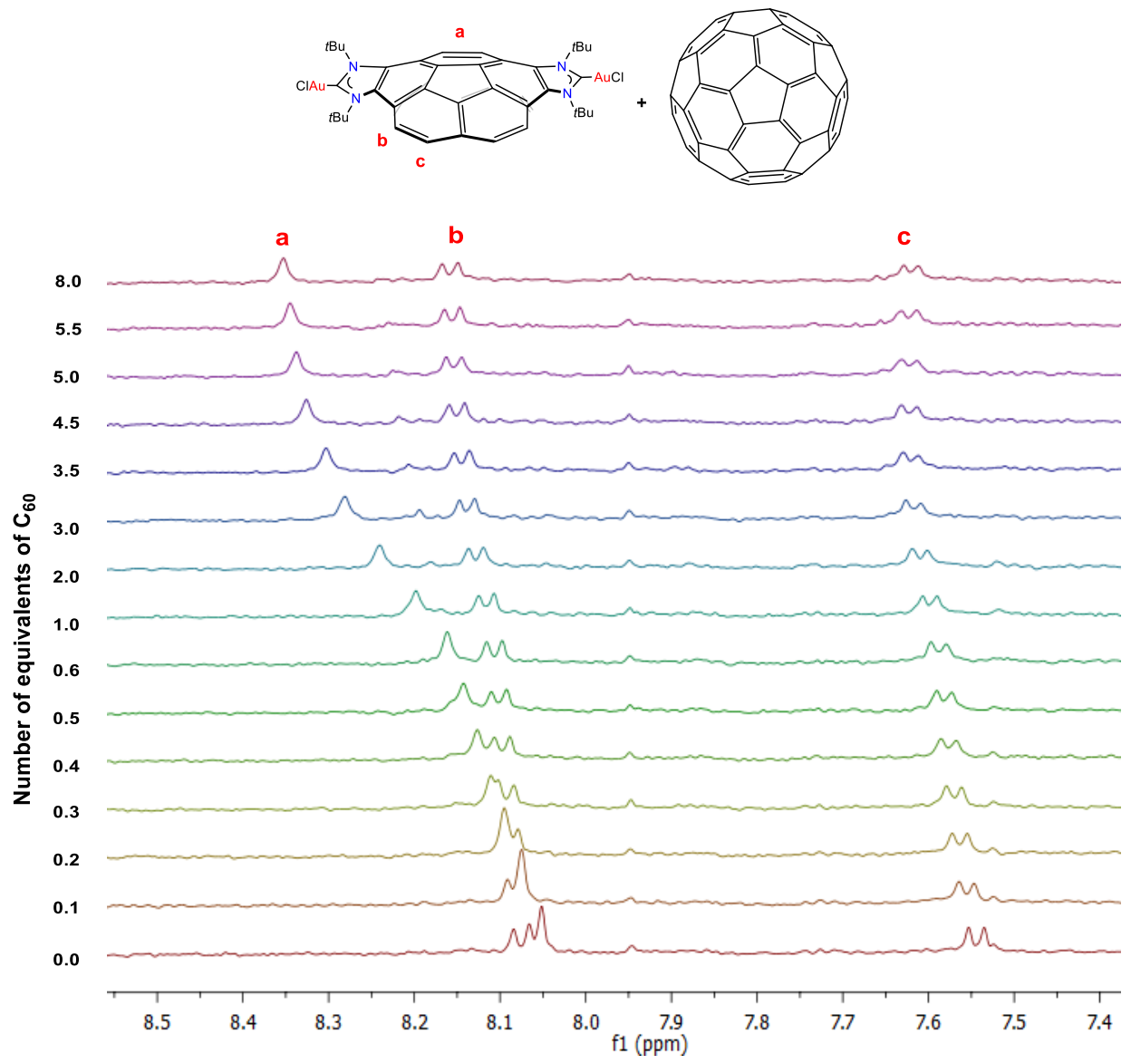

Figure 5.11. Selected region of the ${ }^{1} \mathrm{H}$ NMR ( $500 \mathrm{MHz}$, toluene- $d_{8}$, $298 \mathrm{~K}$ ) spectra registered during the titration of $\mathbf{3} \mathbf{G}^{\mathbf{B u}}$ with incremental amounts of $\mathrm{C}_{60}$ )

Table 5.2. Data values from the titration study of $\mathbf{3 G}^{t \mathbf{B u}}$ with $\mathrm{C}_{60}$

\begin{tabular}{|c|c|c|c|c|c|}
\hline$\left[3 G^{t \mathrm{Bu}}\right]$ & {$\left[\mathbf{C}_{60}\right]$} & $\delta(\mathrm{ppm})$ for $\mathrm{Ha}$ & $\delta(\mathrm{ppm})$ for $\mathrm{Hb}$ & $\delta(\mathrm{ppm})$ for $\mathrm{Hc}$ & {$\left[3 \mathrm{G}^{t \mathrm{Bu}}\right] /\left[\mathrm{C}_{60}\right]$} \\
\hline 0,49 & 0 & 8,051 & 8,083 & 7,552 & 0 \\
\hline 0,49 & 0,05 & 8,074 & 8,090 & 7,564 & 0,10 \\
\hline 0,49 & 0,10 & 8,095 & 8,095 & 7,571 & 0,19 \\
\hline 0,49 & 0,14 & 8,110 & 8,101 & 7,578 & 0,29 \\
\hline 0,49 & 0,19 & 8,126 & 8,106 & 7,585 & 0,38 \\
\hline 0,49 & 0,23 & 8,142 & 8,110 & 7,590 & 0,47 \\
\hline 0,49 & 0,31 & 8,161 & 8,116 & 7,597 & 0,64 \\
\hline 0,49 & 0,54 & 8,198 & 8,124 & 7,606 & 1,11 \\
\hline
\end{tabular}




$\begin{array}{rrrrrr}0,49 & 0,87 & 8,240 & 8,136 & 7,618 & 1,77 \\ 0,49 & 1,36 & 8,281 & 8,147 & 7,626 & 2,77 \\ 0,49 & 1,71 & 8,303 & 8,153 & 7,630 & 3,49 \\ 0,49 & 2,19 & 8,326 & 8,159 & 7,630 & 4,46 \\ 0,49 & 2,49 & 8,337 & 8,163 & 7,630 & 5,08 \\ 0,49 & 2,71 & 8,345 & 8,165 & 7,630 & 5,51 \\ 0,49 & 3,89 & 8,354 & 8,167 & 7,627 & 7,92\end{array}$

Figure 5.12. ${ }^{1} \mathrm{H}$ NMR chemical shifts $\delta(\mathrm{ppm})$ plotted against $[\mathrm{G}] /[\mathrm{H}]$
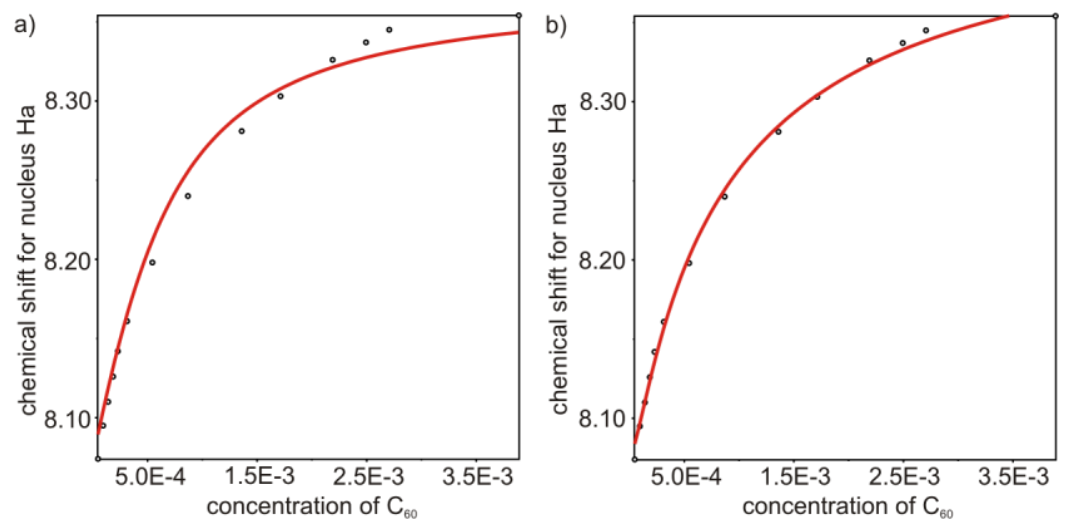

Figure 5.13. Non-linear least-squares fitting (red line) of the chemical shift changes of Ha during the titration of $\mathbf{3 G}^{\mathbf{t} \mathbf{B u}}$ with $\mathrm{C}_{60}$ to: a) 1:1 binding model, $\mathrm{K}_{\mathrm{a}}=2750 \pm 300 \mathrm{M}^{-1}$ and b) 1:3 binding model assuming that the binding constants for the single binding steps leading to the $\mathrm{C}_{60} @\left(\mathbf{3 G}^{\mathbf{t} \mathbf{B u}}\right)_{2}$ and $\mathrm{C}_{60} @\left(\mathbf{3 G}^{\mathbf{t}^{\mathrm{Bu}}}\right)_{3}$ are identical and coincide with $\mathrm{K}_{\mathrm{a}}\left(\mathrm{C}_{60} @ \mathbf{3 G}^{\mathbf{t} \mathbf{B u}}\right)=2750 \pm 300 \mathrm{M}^{-1}$. HypNMR 2008 4.0.71 
a)

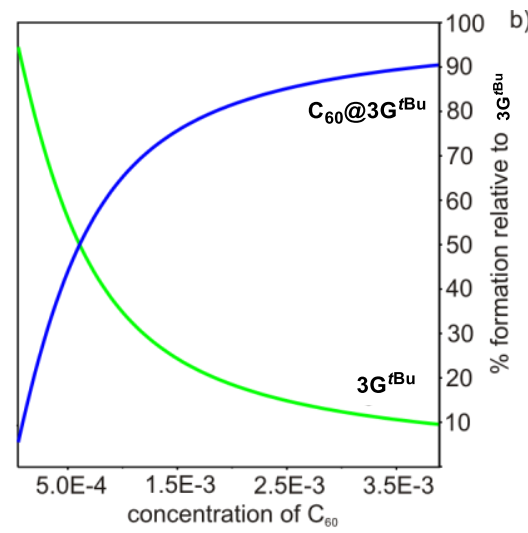

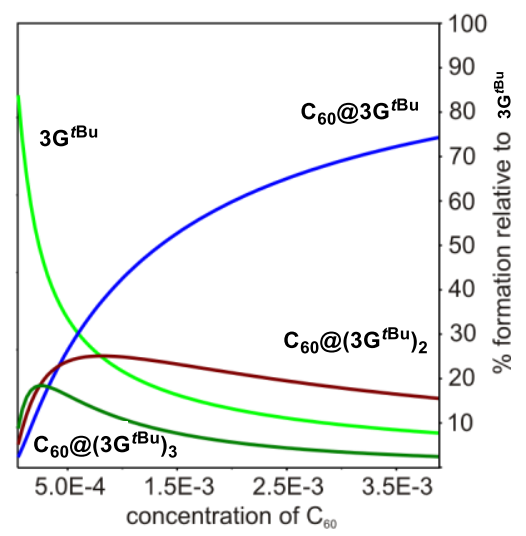

Figure 5.14. Speciation profiles for: a) 1:1 binding model, $K_{a}=2750 \pm 300 \mathrm{M}^{-1}$ and b) 1:3 binding model assuming that the bindind constants for the single binding steps leading to the $\mathrm{C}_{60} @\left(\mathbf{3 G}^{\mathbf{t} \mathbf{B u}}\right)_{2}$ and $\mathrm{C}_{60} @\left(\mathbf{3 G}^{t \mathbf{B u}}\right)_{3}$ are identical and coincide with $\mathrm{K}_{\mathrm{a}}\left(\mathrm{C}_{60} @ \mathbf{3 G}^{t \mathbf{B u}}\right)=2750 \pm 300 \mathrm{M}^{-1}$. HypNMR 2008 4.0.71

Table 5.3. Calculated chemical shifts for the Ha protons in the $\mathrm{C}_{60} @\left(\mathbf{3 G}^{t \mathbf{B u}}\right)_{\mathrm{n}}(\mathrm{n}=1 ; 2$ and 3$)$ complexes obtained in the non-linear least-squares fitting to a 1:1 and 1:3 binding models. HypNMR 2008 4.0.71

\begin{tabular}{cccc}
\hline Binding model & $\begin{array}{c}\boldsymbol{\delta}(\mathbf{p p m}) \text { for Ha } \\
(\mathbf{n}=\mathbf{1})\end{array}$ & $\begin{array}{c}\boldsymbol{\delta}(\mathbf{p p m}) \text { for Ha } \\
(\mathbf{n}=\mathbf{2})\end{array}$ & $\begin{array}{c}\boldsymbol{\delta}(\mathbf{p p m}) \text { for Ha } \\
(\mathbf{n}=\mathbf{3})\end{array}$ \\
\hline $1: 1$ & 8.37 & & \\
$1: 3$ & 8.43 & 8.23 & 8.01 \\
\hline
\end{tabular}

\section{Host-guest studies bv ${ }^{1} \mathrm{H}$ NMR titrations with Coronene}

Stock solutions of $\mathbf{3 G}^{\mathbf{t} \mathbf{B u}}$ and coronene were prepared in toluene- $d_{8}$. Solution A) 1.55 $\mathrm{mM}$ of $\mathbf{3 G}^{\mathbf{t} \mathbf{B u}}$ and solution B) $2 \mathrm{mM}$ of coronene and $1.55 \mathrm{mM}$ of $\mathbf{3 G}^{\mathbf{t} \mathbf{B u}}$. Solution A was placed in a NMR tube and aliquots of solution B were added. The concentration of host $\mathbf{3 G}^{\mathbf{B u}}$ was maintained constant throughout the titration. ${ }^{1} \mathrm{H}$ NMR spectra were directly recorded after each addition. 

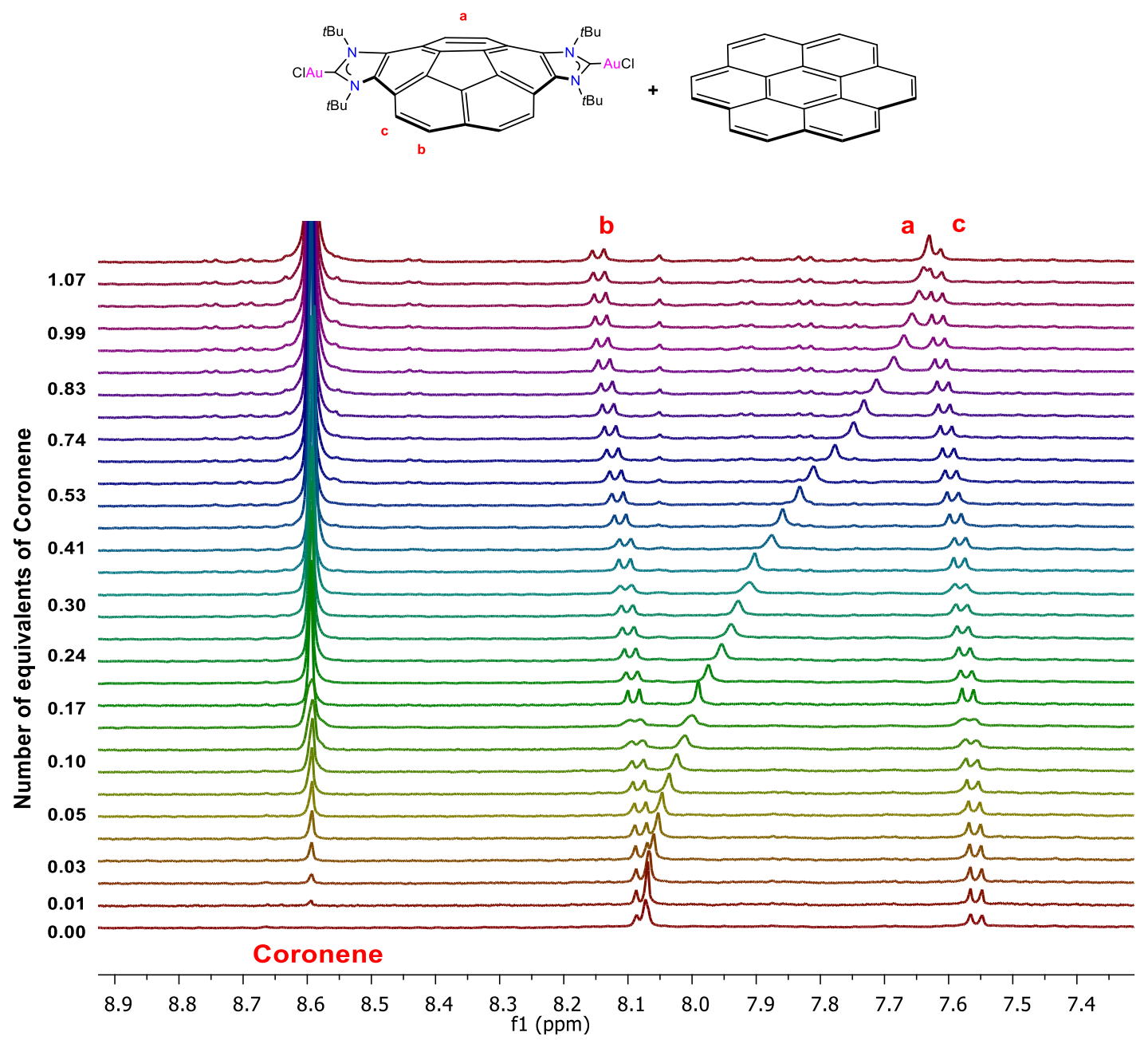

Figure 5.14. Selected region of the ${ }^{1} \mathrm{H}$ NMR (500 MHz, toluene- $d_{8}, 298 \mathrm{~K}$ ) spectra registered during the titration of $\mathbf{3 G}^{\mathbf{t}} \mathbf{\mathrm { Bu }}$ with incremental amounts of coronene)

Table 5.4. Data values from the titration study of $\mathbf{3 G}^{\boldsymbol{t} \mathbf{B u}}$ with Coronene

\begin{tabular}{cccc}
\hline$\left[\mathbf{3 G}^{\mathbf{B u}}\right]$ & {$[$ Coronene $]$} & $\boldsymbol{\delta}(\mathbf{p p m})$ for Ha & {$\left[\mathbf{3 G}^{\mathrm{t} \mathbf{B u}}\right] /[$ Coronene $]$} \\
\hline 1,55 & 0 & 8,072 & 0 \\
1,55 & 0,00995025 & 8,069 & 0,006437148 \\
1,55 & 0,01980198 & 8,068 & 0,012810561 \\
1,55 & 0,03921569 & 8,06 & 0,025369935 \\
1,55 & 0,05825243 & 8,053 & 0,037685437 \\
1,55 & 0,07692308 & 8,047 & 0,049764103 \\
1,55 & 0,11320755 & 8,036 & 0,073237736
\end{tabular}




\begin{tabular}{|c|c|c|c|}
\hline 1,55 & 0,14814815 & 8,024 & 0,095841975 \\
\hline 1,55 & 0,19004525 & 8,011 & 0,122946606 \\
\hline 1,55 & 0,2300885 & 7,999 & 0,148851917 \\
\hline 1,55 & 0,26839827 & 7,99 & 0,173635786 \\
\hline 1,55 & 0,32285115 & 7,975 & 0,208863173 \\
\hline 1,55 & 0,37398374 & 7,954 & 0,241942547 \\
\hline 1,55 & 0,42209073 & 7,939 & 0,273064563 \\
\hline 1,55 & 0,46743295 & 7,928 & 0,302397957 \\
\hline 1,55 & 0,51024209 & 7,911 & 0,330092613 \\
\hline 1,55 & 0,56373429 & 7,902 & 0,364698504 \\
\hline 1,55 & 0,63713799 & 7,875 & 0,412185804 \\
\hline 1,55 & 0,72408293 & 7,859 & 0,468433386 \\
\hline 1,55 & 0,8183161 & 7,832 & 0,529395963 \\
\hline 1,55 & 0,89958735 & 7,81 & 0,58197304 \\
\hline 1,55 & 1,03264813 & 7,777 & 0,668054494 \\
\hline 1,55 & 1,13700108 & 7,748 & 0,735563898 \\
\hline 1,55 & 1,22103213 & 7,732 & 0,789926388 \\
\hline 1,55 & 1,29015084 & 7,712 & 0,834641585 \\
\hline 1,55 & 1,3971364 & 7,685 & 0,903854107 \\
\hline 1,55 & 1,47609692 & 7,669 & 0,954936302 \\
\hline 1,55 & 1,53676896 & 7,657 & 0,994187068 \\
\hline 1,55 & 1,58484691 & 7,646 & 1,025290296 \\
\hline 1,55 & 1,6238834 & 7,639 & 1,050544303 \\
\hline 1,55 & 1,65620971 & 7,63 & 1,07145727 \\
\hline
\end{tabular}




\section{Host-guest studies bv fluorescence spectroscopv}

Stock solutions of $\mathbf{3 G}^{\mathbf{t} \mathbf{B u}}$ and $\mathrm{C}_{60}$ were prepared in toluene: Solution A) $0.02 \mathrm{mM}$ of $\mathbf{3 G}^{\mathbf{t} \mathbf{B u}}$ and solution B) $0.2 \mathrm{mM}$ of $\mathrm{C}_{60}$ and $0.02 \mathrm{mM}$ of $\mathbf{3 G}^{\mathbf{t} \mathbf{B u}}$. Solution A was placed in a fluorescence cubette and aliquots of solution B were added. The fluorescence spectra (excitation wavelenght $=403 \mathrm{~nm}$ ) of the titration of host $\mathbf{3 G}^{\mathbf{t} \mathbf{B u}}$ against $\mathrm{C}_{60}$ were directly recorded after each addition. The concentration of $\mathbf{3 G}^{\boldsymbol{t} \mathbf{B u}}$ was maintained constant throughout the titration.

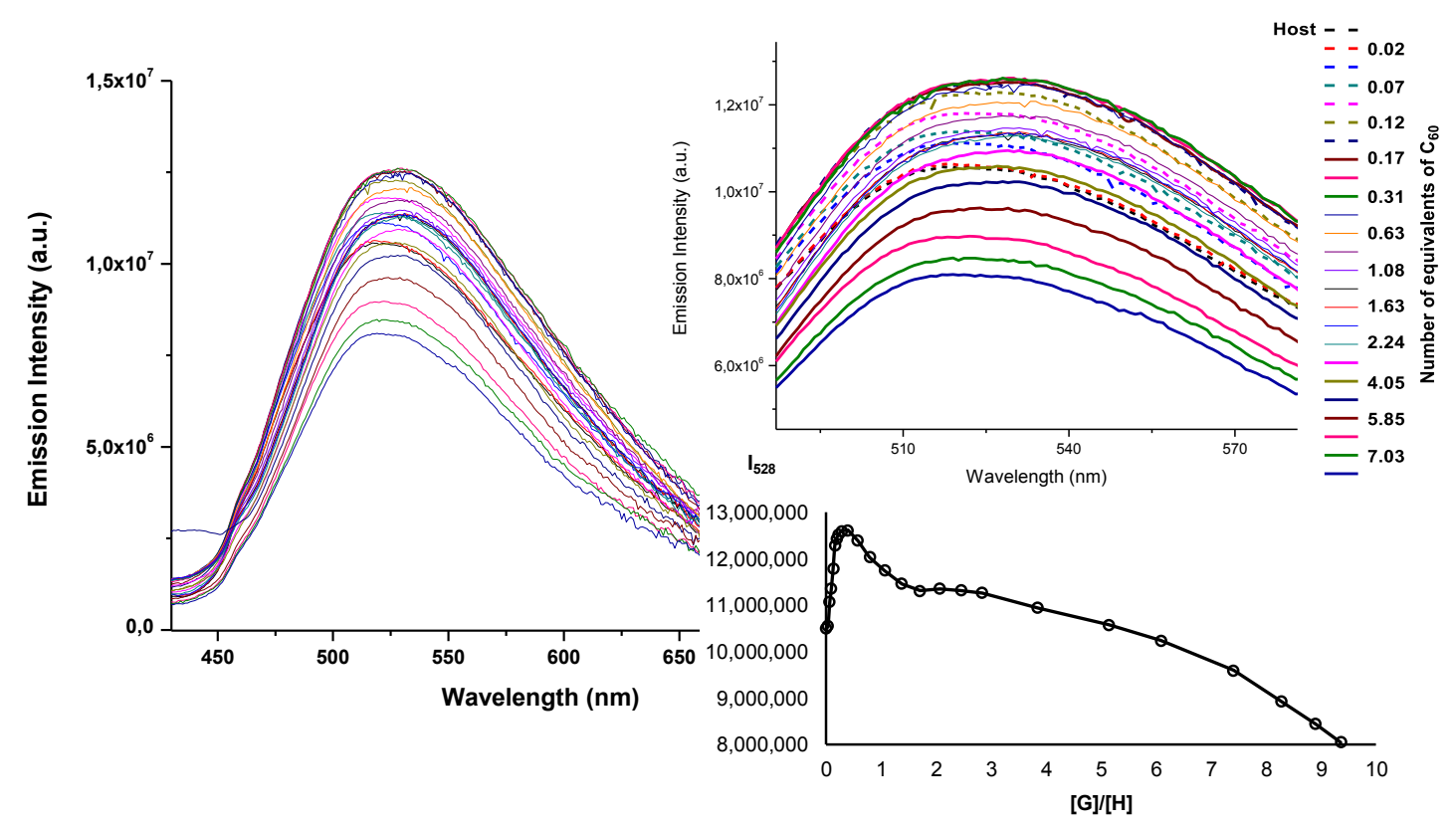

Figure 5.15. Fluorescence spectra registered during the titration of $\mathbf{3 G}^{\mathbf{t}} \mathbf{\text { u}}$ with $\mathrm{C}_{60}$ in toluene at $298 \mathrm{~K}$ $($ excitation wavelenght $=403 \mathrm{~nm})(\mathrm{Left})$ Emission intensity $(528 \mathrm{~nm}) \mathrm{vs}$ guest/host ratio plot $($ Bottom-

$$
\text { Right) }
$$

Table 5.5. Data values from the titration study of $\mathbf{3 G}^{\mathbf{t} \mathbf{B u}}$ with $\mathrm{C}_{60}$

\begin{tabular}{cccc}
\hline$\left[\mathbf{3 G}^{\mathbf{B u}}\right]$ & {$\left[\mathbf{C}_{\mathbf{6 0}}\right]$} & $\mathbf{I}(\mathbf{5 2 8} \mathbf{~ n m})$ & $\left.\left[\mathbf{3 G}^{\mathbf{t}}\right]^{\mathrm{Bu}}\right] /\left[\mathbf{C}_{\mathbf{6 0}}\right]$ \\
\hline 1,55 & 0 & $1,05 \mathrm{E}+07$ & 0 \\
1,55 & $4,849 \mathrm{E}-07$ & $1,05 \mathrm{E}+07$ & 0,031283798 \\
1,55 & $9,6739 \mathrm{E}-07$ & $1,11 \mathrm{E}+07$ & 0,062411955 \\
1,55 & $1,4475 \mathrm{E}-06$ & $1,14 \mathrm{E}+07$ & 0,093385629 \\
1,55 & $1,9252 \mathrm{E}-06$ & $1,18 \mathrm{E}+07$ & 0,124205969 \\
1,55 & $2,4005 \mathrm{E}-06$ & $1,23 \mathrm{E}+07$ & 0,154874109
\end{tabular}




\begin{tabular}{|c|c|c|c|}
\hline 1,55 & $2,8736 \mathrm{E}-06$ & $1,24 \mathrm{E}+07$ & 0,185391175 \\
\hline 1,55 & $3,3443 \mathrm{E}-06$ & $1,25 \mathrm{E}+07$ & 0,21575828 \\
\hline 1,55 & $4,2787 \mathrm{E}-06$ & $1,26 \mathrm{E}+07$ & 0,276047007 \\
\hline 1,55 & $6,1205 \mathrm{E}-06$ & $1,26 \mathrm{E}+07$ & 0,394872729 \\
\hline 1,55 & $8,8173 \mathrm{E}-06$ & $1,24 \mathrm{E}+07$ & 0,568857409 \\
\hline 1,55 & $1,2295 \mathrm{E}-05$ & $1,20 \mathrm{E}+07$ & 0,793231095 \\
\hline 1,55 & $1,6463 \mathrm{E}-05$ & $1,17 \mathrm{E}+07$ & 1,062145781 \\
\hline 1,55 & $2,122 \mathrm{E}-05$ & $1,15 \mathrm{E}+07$ & 1,369031939 \\
\hline 1,55 & $2,6458 \mathrm{E}-05$ & $1,13 \mathrm{E}+07$ & 1,706960217 \\
\hline 1,55 & $3,2069 \mathrm{E}-05$ & $1,13 \mathrm{E}+07$ & 2,068975838 \\
\hline 1,55 & $3,795 \mathrm{E}-05$ & $1,13 \mathrm{E}+07$ & 2,448382049 \\
\hline 1,55 & $4,4004 \mathrm{E}-05$ & $1,13 \mathrm{E}+07$ & 2,838959256 \\
\hline 1,55 & $5,9648 \mathrm{E}-05$ & $1,09 \mathrm{E}+07$ & 3,848232422 \\
\hline 1,55 & $7,9559 \mathrm{E}-05$ & $1,06 \mathrm{E}+07$ & 5,132807082 \\
\hline 1,55 & $9,4344 \mathrm{E}-05$ & $1,02 \mathrm{E}+07$ & 6,086731893 \\
\hline 1,55 & 0,00011484 & $9,59 \mathrm{E}+06$ & 7,408752563 \\
\hline 1,55 & 0,00012836 & $8,92 \mathrm{E}+06$ & 8,281488384 \\
\hline 1,55 & 0,00013796 & $8,44 \mathrm{E}+06$ & 8,900706174 \\
\hline 1,55 & 0,00014512 & $8,04 \mathrm{E}+06$ & 9,362861747 \\
\hline
\end{tabular}

\section{Isothermal Titration Calorimetry (ITC)}

Titration of host $\mathbf{3 G}^{\mathbf{t} \mathbf{B u}}$ with $\mathrm{C}_{60}$ was carried out in toluene solution by the addition of small aliquots of $\mathrm{C}_{60}(8 \mu \mathrm{L})$ of a solution of the guest $(3.8 \mathrm{mM})$ into a solution of the host $\mathbf{3 G}^{\mathbf{B u}}(0.6 \mathrm{mM})$. The association constants and the thermodynamic parameters were obtained from the fit of the titration data to a 1:3 binding model (one set of sites) using the Microcal ITC Data Analysis Module indicating that the multitopic substrate 
$\left(\mathrm{C}_{60}\right)$ was placed in the syringe. The reported data represent the averaged thermodynamic values for each site. The three sites are assumed to be non-cooperative.

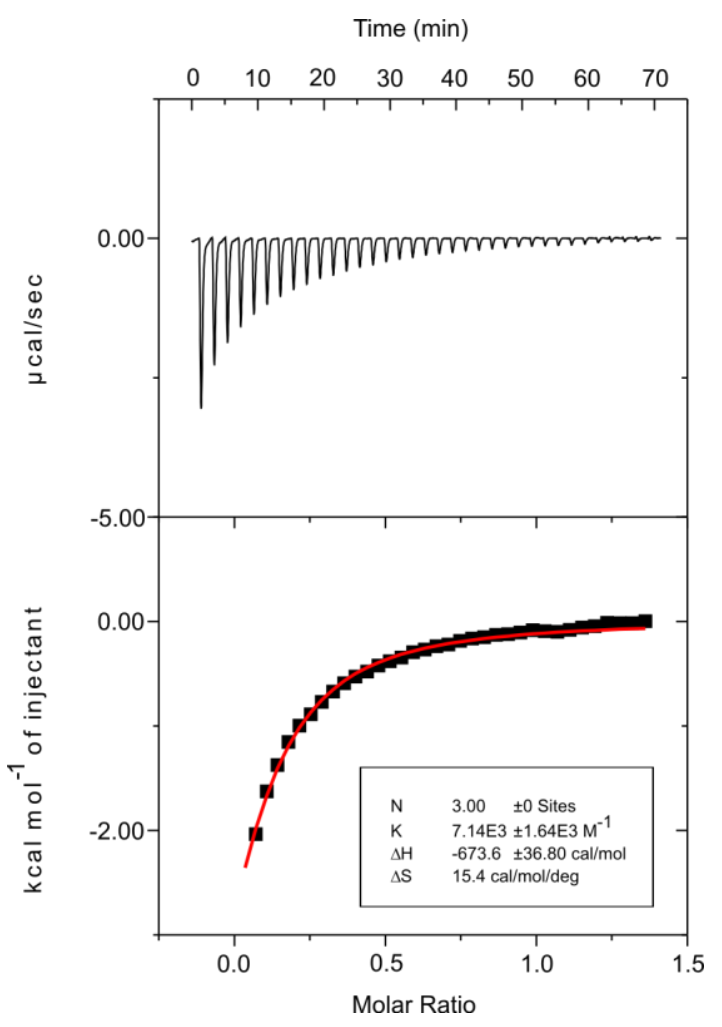

Figure 5.16. Heat vs time plot for the titration of guest $\mathrm{C}_{60}$ into host $\mathbf{3 G}^{\boldsymbol{t}^{\mathbf{B u}}}$ (top). "One set of sites" binding isotherm (red line) fit to the experimental data assuming that the complex of higher stoichiometry formed by the two binding partners is $\mathrm{C}_{60} @\left(\mathbf{3 G}^{\mathbf{t} \mathbf{u u}}\right)_{3}$ (bottom).The model assumes that all binding sites are almost identical.

Table 5.6 Thermodynamic parameters obtained from the ITC binding experiment (average data from two different experiments at $298 \mathrm{~K}$ ). Errors (given as standard deviation) were determined from the experimental results

\begin{tabular}{|c|c|c|c|c|}
\hline Complex & $K_{a}\left(M^{-1}\right)$ & $\Delta H\left(k^{\prime c a l ~ m o l}{ }^{-1}\right)$ & -T $\Delta S\left(\right.$ kcal mol $\left.^{-1}\right)$ & $\Delta G\left(\mathrm{kcal} \mathrm{mol}^{-1}\right)$ \\
\hline $\mathrm{C}_{60} @\left(\mathbf{3 G}^{t \mathrm{Bu}}\right)_{3}$ & $7.1 \pm 0.3 \times 10^{3}$ & $-0.67 \pm 0.07$ & $-4.6 \pm 0.5$ & $-5.3 \pm 0.5$ \\
\hline
\end{tabular}

\section{$\underline{\text { DFT calculations }}$}

The calculations were carried out in Gaussian 09 ${ }^{[10]}$ (rev. D.01) using the M06-L, ${ }^{[11]}$ B97D3, ${ }^{[15]} \mathrm{B} 97 \mathrm{D},{ }^{[16]}$ and $\omega \mathrm{B} 97 \mathrm{X}-\mathrm{D}^{[17]}$ functionals. In M06L-D3 calculations, the D3 
version of Grimme's dispersion with the original D3 damping function ${ }^{[18]}$ was added to M06-L with the "EmpiricalDispersion=GD3" keyword. The basis sets included def2QZVP (with def2-ECP) for Au and def2-SVP for all other atoms together (when using the local finctionals) with the W06 density fitting basis set. ${ }^{[19]}$ The polarizable continuum model (IEFPCM) was used in all calculations in toluene solvent, with the radii and non-electrostatic terms of Truhlar and co-workers' SMD solvation model (scrf $=$ smd) ${ }^{[13]}$ All geometry optimizations were accompanied by frequency calculations at $298.15 \mathrm{~K}$, under pressure $=230 \mathrm{~atm}$, following the approach of Martin and coworkers. ${ }^{[14 a]}$ Ultimately, the calculated thermal corrections to enthalpy and Gibbs free energy were combined with the electronic energies from single-point calculations on the optimized geometries using the def2-QZVP basis set for all atoms.

Table 5.7 shows the enthalpies $\left(\mathrm{kcal} / \mathrm{mol}\right.$ ) of toluene binding to $\mathbf{3 G}^{\boldsymbol{t} \mathbf{B u}}$ and $\mathbf{3 G}^{\mathbf{M e}}$ in toluene at $298 \mathrm{~K}$, per mole of toluene, calculated by different methods (M1-M5).

Table 5.7. Enthalpies of formation between di-gold complex and toluene

\begin{tabular}{cccc}
\hline 3G $^{t \mathbf{B u}} @$ toluene $(\mathrm{kcal})$ & $\mathbf{3 G}^{\mathbf{t} \mathrm{Bu}} @$ toluene $_{2}(\mathrm{kcal})$ \\
\hline M1 & -5.7 & $\mathbf{M 1}$ & -6.9 \\
M2 & -8.1 & $\mathbf{M 2}$ & -9.9 \\
M3 & -9.6 & M3 & -9.4 \\
M4 & -10.1 & M4 & -10.8 \\
M5 & -11.4 & M5 & -12.1 \\
\hline
\end{tabular}

Table 5.8 shows the enthalpies $(\mathrm{kcal} / \mathrm{mol})$ and entropies $\left(\mathrm{cal} \cdot \mathrm{K}^{-1} \cdot \mathrm{mol}^{-1}\right)$ of formation in toluene at $298 \mathrm{~K}$, per mole of $\mathbf{3 G}^{\mathrm{Me}} @$ toluene, calculated by different methods (M1M4).

Table 5.8. Enthalpies and entropies of formation

\begin{tabular}{ccccccc}
\hline Method & \multicolumn{1}{c}{$\mathbf{C}_{60} @\left(\mathbf{3 G}^{\mathrm{Me}}\right)$} & \multicolumn{1}{c}{$\mathbf{C}_{60} @\left(\mathbf{3 G}^{\mathbf{M e}}\right)_{\mathbf{2}}$} & \multicolumn{2}{c}{$\mathbf{C}_{60} @\left(\mathbf{3 G}^{\mathrm{Me}}\right)_{\mathbf{3}}$} \\
\hline & $\Delta \mathrm{H}$ & $\Delta \mathrm{S}$ & $\Delta \mathrm{H}$ & $\Delta \mathrm{S}$ & $\Delta \mathrm{H}$ & $\Delta \mathrm{S}$ \\
$\mathbf{M 1}$ & 4.3 & 27 & 0.6 & 24 & -2.6 & 19 \\
$\mathbf{M 2}$ & 2.5 & 28 & -2.1 & 21 & -6.2 & 18 \\
M3 & 2.2 & 18 & -3.6 & 20 & -7.7 & 18 \\
M4 & -0.2 & 21 & -8.3 & 19 & -12.8 & 16 \\
\hline
\end{tabular}


Table 5.9 shows the enthalpies $(\mathrm{kcal} / \mathrm{mol})$ and entropies $\left(\mathrm{cal} . \mathrm{K}^{-1} \cdot \mathrm{mol}^{-1}\right)$ of formation of $\mathrm{C}_{60} @ \mathbf{3 G}^{t \mathbf{B u}}$ and $\mathrm{C}_{60} @\left(\mathbf{3 G}^{t \mathbf{B u}}\right)_{2}$ in toluene at $298 \mathrm{~K}$, per mol of $\mathbf{3 G}^{t \mathbf{B u}} @$ toluene, calculated by different methods (M1-M4).

Table 5.9. Enthalpies and entropies of formation

\begin{tabular}{ccccc}
\hline Method & \multicolumn{2}{c}{$\mathbf{C}_{60} @\left(\mathbf{3 G}^{\mathbf{t}}{ }^{\mathrm{Bu}}\right)$} & \multicolumn{2}{c}{$\mathbf{C}_{60} @\left(\mathbf{3 G}^{\mathbf{t}}\right)_{\mathbf{2}}$} \\
\hline & $\Delta \mathrm{H}$ & $\Delta \mathrm{S}$ & $\Delta \mathrm{H}$ & $\Delta \mathrm{S}$ \\
$\mathbf{M 1}$ & 3.8 & 19 & -2.2 & 17 \\
$\mathbf{M} 2$ & 1.1 & 16 & 6.4 & 17 \\
$\mathbf{M 3}$ & -1.2 & 21 & -7.4 & 22 \\
$\mathbf{M 4}$ & -4.4 & 22 & -11.8 & 19 \\
\hline
\end{tabular}

\subsection{X-Ray diffraction}

Single crystal suitable for X-Ray Diffraction were mainly obtained by slow diffusion of hexane or $\mathrm{Et}_{2} \mathrm{O}$ into a concentrated solution of the compound in different solvents or slow evaporation of a concentrated solution of the compound in the appropriated solvent. Diffraction data were collected on an Agilent SuperNova diffractometer equipped with an Atlas CCD detector. Single crystals were mounted on a MicroMount polymer tip (MiteGen) in a random orientation. Absortion corrections based on the multiscan method were applied. ${ }^{[20]}$ The structures were solved by direct methods in SHELXS-97 and refined by the full-matrix method based on $\mathrm{F}^{2}$ with the program SHELXL-97 using OLEX software package. ${ }^{[1-2]}$

Key details of the crystals and structures refinement data are summarized in the following tables. 
Table 5.10 Structural parameters, register conditions and refinement of $\left[\mathrm{H}_{3} \mathrm{~B}^{\mathrm{Me}}\right]\left(\mathrm{CF}_{3} \mathrm{SO}_{3}\right)_{3}$

\begin{tabular}{|c|c|}
\hline & {$\left[\mathrm{H}_{3} \mathrm{~B}^{\mathrm{Me}}\right]\left(\mathrm{CF}_{3} \mathrm{SO}_{3}\right)_{3}$} \\
\hline Empirical formula & $\mathrm{C}_{150} \mathrm{H}_{132} \mathrm{~F}_{18} \mathrm{~N}_{24} \mathrm{O}_{18} \mathrm{~S}_{6}$ \\
\hline Formula weight & 515.52 \\
\hline Temperature/K & 293(2) \\
\hline Crystal system & Trigonal \\
\hline Space group & $\mathrm{R}-3$ \\
\hline $\mathrm{a} / \AA$ & $34.2772(14)$ \\
\hline $\mathrm{b} / \AA$ & $34.2772(14)$ \\
\hline $\mathrm{c} / \AA ̊$ & $14.1208(6)$ \\
\hline$\alpha /^{\circ}$ & 90 \\
\hline$\beta /^{\circ}$ & 90 \\
\hline$\gamma /{ }^{\circ}$ & 120 \\
\hline Volume $/ \AA^{3}$ & 14368.1(13) \\
\hline $\mathrm{Z}$ & 3 \\
\hline$\rho_{\text {calc }} \mathrm{g} / \mathrm{cm}^{3}$ & 1.072 \\
\hline$\mu / \mathrm{mm}^{-1}$ & 1.294 \\
\hline $\mathrm{F}(000)$ & 4806.0 \\
\hline Crystal size $/ \mathrm{mm}^{3}$ & $0.18 \times 0.13 \times 0.11$ \\
\hline $2 \Theta$ range for data collection & 6.932 to $121.99^{\circ}$ \\
\hline Index ranges & $\begin{array}{c}-38 \leq \mathrm{h} \leq 34,-38 \leq \mathrm{k} \leq 38,-14 \leq 1 \leq \\
15\end{array}$ \\
\hline Reflections collected & 13623 \\
\hline Independent reflections & $4812[\mathrm{R}(\mathrm{int})=0.0285]$ \\
\hline Data/restraints/parameters & $4812 / 0 / 331$ \\
\hline Goodness-of-fit on $\mathrm{F}^{2}$ & 1.113 \\
\hline Final $R$ indexes $[\mathrm{I}>=2 \sigma(\mathrm{I})]$ & $\mathrm{R}_{1}=0.0765, \mathrm{wR}_{2}=0.02461$ \\
\hline Final $\mathrm{R}$ indexes [all data] & $\mathrm{R}_{1}=0.0930, \mathrm{wR}_{2}=0.2626$ \\
\hline Largest diff. peak/hole / e $\AA^{-3}$ & $0.23 /-0.28$ \\
\hline
\end{tabular}


Table 5.11 Structural parameters, register conditions and refinement of $\mathbf{1 D}^{\mathbf{E t}}$

\begin{tabular}{|c|c|}
\hline & $1 D^{E t}$ \\
\hline Empirical formula & $\mathrm{C}_{24} \mathrm{HClN}_{7} \mathrm{Rh}$ \\
\hline Formula weight & 418.77 \\
\hline Temperature/K & $200(10)$ \\
\hline Crystal system & Monoclinic \\
\hline Space group & $\mathrm{P} 2{ }_{1} / \mathrm{a}$ \\
\hline $\mathrm{a} / \AA$ & $10.1941(3)$ \\
\hline $\mathrm{b} / \AA$ & $17.6476(4)$ \\
\hline $\mathrm{c} / \AA$ & $10.3104(3)$ \\
\hline$\alpha /{ }^{\circ}$ & 90 \\
\hline$\beta /{ }^{\circ}$ & $101.886(3)$ \\
\hline$\gamma /{ }^{\circ}$ & 90 \\
\hline Volume $/ \AA^{3}$ & $1815.08(8)$ \\
\hline Z & 4 \\
\hline$\rho_{\text {calc }} \mathrm{g} / \mathrm{cm}^{3}$ & 1.45324 \\
\hline$\mu / \mathrm{mm}^{-1}$ & 1.089 \\
\hline $\mathrm{F}(000)$ & 852.3 \\
\hline Crystal size $/ \mathrm{mm}^{3}$ & $0.4043 \times 0.1787 \times 0.1169$ \\
\hline $2 \Theta$ range for data collection & 5.62 to $58.84^{\circ}$ \\
\hline Index ranges & $\begin{array}{c}-13 \leq \mathrm{h} \leq 13,-23 \leq \mathrm{k} \leq 24,-13 \leq 1 \leq \\
14\end{array}$ \\
\hline Reflections collected & 39071 \\
\hline Independent reflections & $4737[\mathrm{R}($ int $)=0.0605]$ \\
\hline Data/restraints/parameters & $4737 / 0 / 303$ \\
\hline Goodness-of-fit on $\mathrm{F}^{2}$ & 1.080 \\
\hline Final $R$ indexes $[\mathrm{I}>=2 \sigma(\mathrm{I})]$ & $\mathrm{R}_{1}=0.0270, \mathrm{wR}_{2}=0.0557$ \\
\hline Final $\mathrm{R}$ indexes [all data] & $\mathrm{R}_{1}=0.0380, \mathrm{wR}_{2}=0.0648$ \\
\hline Largest diff. peak/hole / e $\AA^{-3}$ & $0.72 /-0.63$ \\
\hline
\end{tabular}


Table 5.12 Structural parameters, register conditions and refinement of $\left[\mathbf{6 B}^{\mathrm{Et}}\right]\left(\mathbf{P F}_{\mathbf{6}}\right)_{3}$

\begin{tabular}{|c|c|}
\hline & {$\left[6 B^{\mathrm{Et}}\right]\left(\mathrm{PF}_{6}\right)_{3}$} \\
\hline Empirical formula & $\mathrm{C}_{100} \mathrm{H}_{125} \mathrm{Au}_{3} \mathrm{~F}_{18} \mathrm{~N}_{13} \mathrm{O}_{5} \mathrm{P}_{3}$ \\
\hline Formula weight & 2614.94 \\
\hline Temperature/K & $153(2)$ \\
\hline Crystal system & Monoclinic \\
\hline Space group & $\mathrm{P} 2{ }_{1} / \mathrm{n}$ \\
\hline $\mathrm{a} / \AA$ & $20.4029(11)$ \\
\hline $\mathrm{b} / \AA$ & $13.2486(8)$ \\
\hline $\mathrm{c} / \AA ̊$ & $33.8848(18)$ \\
\hline$\alpha /^{\circ}$ & 90 \\
\hline$\beta /{ }^{\circ}$ & $93.936(3)$ \\
\hline$\gamma /{ }^{\circ}$ & 90 \\
\hline Volume $/ \AA^{3}$ & $9137.8(9)$ \\
\hline $\mathrm{Z}$ & 4 \\
\hline$\rho_{\text {calc }} \mathrm{g} / \mathrm{cm}^{3}$ & 1.901 \\
\hline$\mu / \mathrm{mm}^{-1}$ & 4.960 \\
\hline $\mathrm{F}(000)$ & 5200.0 \\
\hline Crystal size $/ \mathrm{mm}^{3}$ & $0.23 \times 0.07 \times 0.03$ \\
\hline $2 \Theta$ range for data collection & 2.26 to $62.1^{\circ}$ \\
\hline Index ranges & $\begin{array}{c}-29 \leq \mathrm{h} \leq 29,-18 \leq \mathrm{k} \leq 19,-48 \leq 1 \leq \\
48\end{array}$ \\
\hline Reflections collected & 131138 \\
\hline Independent reflections & $28577[\mathrm{R}(\mathrm{int})=0.0841]$ \\
\hline Data/restraints/parameters & $28577 / 31 / 996$ \\
\hline Goodness-of-fit on $\mathrm{F}^{2}$ & 0.987 \\
\hline Final $R$ indexes $[\mathrm{I}>=2 \sigma(\mathrm{I})]$ & $\mathrm{R}_{1}=0.0585, \mathrm{wR}_{2}=0.1473$ \\
\hline Final $\mathrm{R}$ indexes [all data] & $\mathrm{R}_{1}=0.1105, \mathrm{wR}_{2}=0.1632$ \\
\hline Largest diff. peak/hole / e $\AA^{-3}$ & $3.12 /-2.46$ \\
\hline
\end{tabular}


Table 5.13 Structural parameters, register conditions and refinement of $\left[\mathbf{5 C}^{\mathbf{M e s}}\right]\left(\mathbf{P F}_{\mathbf{6}} \mathbf{3}_{\mathbf{3}}\right.$

\begin{tabular}{|c|c|}
\hline & {$\left[5 C^{\mathrm{Mes}}\right]\left(\mathrm{PF}_{6}\right)_{3}$} \\
\hline Empirical formula & $\mathrm{C}_{168} \mathrm{H}_{162} \mathrm{Ag}_{3} \mathrm{~F}_{18} \mathrm{~N}_{18} \mathrm{P}_{3}$ \\
\hline Formula weight & 3191.67 \\
\hline Temperature/K & $150.00(14)$ \\
\hline Crystal system & Trigonal \\
\hline Space group & $\mathrm{R}-3$ \\
\hline $\mathrm{a} / \AA$ & $35.4661(16)$ \\
\hline $\mathrm{b} / \AA$ & $35.4661(16)$ \\
\hline $\mathrm{c} / \AA \AA$ & $26.1940(17)$ \\
\hline$\alpha /{ }^{\circ}$ & 90 \\
\hline$\beta /{ }^{\circ}$ & 90 \\
\hline$\gamma /{ }^{\circ}$ & 120 \\
\hline Volume $/ \AA^{3}$ & $28534(3)$ \\
\hline $\mathrm{Z}$ & 6 \\
\hline$\rho_{\text {calc }} \mathrm{g} / \mathrm{cm}^{3}$ & 1.114 \\
\hline$\mu / \mathrm{mm}^{-1}$ & 3.228 \\
\hline $\mathrm{F}(000)$ & 9864.0 \\
\hline Crystal size $/ \mathrm{mm}^{3}$ & $0.1117 \times 0.1056 \times 0.0466$ \\
\hline $2 \Theta$ range for data collection & 6.672 to $129.874^{\circ}$ \\
\hline Index ranges & $\begin{array}{c}-36 \leq \mathrm{h} \leq 36,-41 \leq \mathrm{k} \leq 32,-29 \leq 1 \leq \\
30\end{array}$ \\
\hline Reflections collected & 36807 \\
\hline Independent reflections & $10546[\mathrm{R}(\mathrm{int})=0.1245]$ \\
\hline Data/restraints/parameters & $10546 / 238 / 652$ \\
\hline Goodness-of-fit on $\mathrm{F}^{2}$ & 1.054 \\
\hline Final $R$ indexes $[\mathrm{I}>=2 \sigma(\mathrm{I})]$ & $\mathrm{R}_{1}=0.0922, \mathrm{wR}_{2}=0.2561$ \\
\hline Final $\mathrm{R}$ indexes [all data] & $\mathrm{R}_{1}=0.1282, \mathrm{wR}_{2}=0.2886$ \\
\hline Largest diff. peak/hole / e $\AA^{-3}$ & $1.35 /-0.71$ \\
\hline
\end{tabular}


Table 5.14 Structural parameters, register conditions and refinement of $\left[\mathbf{H}_{2} \mathbf{G}^{\mathbf{B u}}\right]\left(\mathbf{P F}_{\mathbf{6}}\right)_{2}$

\begin{tabular}{|c|c|}
\hline & {$\left[\mathrm{H}_{2} \mathrm{G}^{t \mathrm{Bu}}\right]\left(\mathrm{PF}_{6}\right)_{2}$} \\
\hline Empirical formula & $\mathrm{C}_{40} \mathrm{H}_{48} \mathrm{Cl}_{2} \mathrm{~F}_{12} \mathrm{~N}_{4} \mathrm{P}_{2}$ \\
\hline Formula weight & 945.66 \\
\hline Temperature/K & $293(2)$ \\
\hline Crystal system & Monoclinic \\
\hline Space group & $\mathrm{P} 2{ }_{1} / \mathrm{c}$ \\
\hline $\mathrm{a} / \AA$ & $8.36541(17)$ \\
\hline $\mathrm{b} / \AA$ & $15.7033(3)$ \\
\hline $\mathrm{c} / \AA \AA$ & $32.4898(7)$ \\
\hline$\alpha /^{\circ}$ & 90 \\
\hline$\beta /{ }^{\circ}$ & 90.02 \\
\hline$\gamma /{ }^{\circ}$ & 90 \\
\hline Volume $/ \AA^{3}$ & $4268.02(15)$ \\
\hline $\mathrm{Z}$ & 4 \\
\hline$\rho_{\text {calc }} \mathrm{g} / \mathrm{cm}^{3}$ & 1.472 \\
\hline$\mu / \mathrm{mm}^{-1}$ & 2.862 \\
\hline $\mathrm{F}(000)$ & 1952.0 \\
\hline Crystal size $/ \mathrm{mm}^{3}$ & $0.15 \times 0.14 \times 0.13$ \\
\hline $2 \Theta$ range for data collection & 7.83 to $146.44^{\circ}$ \\
\hline Index ranges & $-6 \leq \mathrm{h} \leq 10,-19 \leq \mathrm{k} \leq 17,-39 \leq 1 \leq 39$ \\
\hline Reflections collected & 18156 \\
\hline Independent reflections & $7693[\mathrm{R}(\mathrm{int})=0.0365]$ \\
\hline Data/restraints/parameters & $7693 / 0 / 554$ \\
\hline Goodness-of-fit on $\mathrm{F}^{2}$ & 1.050 \\
\hline Final $R$ indexes $[\mathrm{I}>=2 \sigma(\mathrm{I})]$ & $\mathrm{R}_{1}=0.0499, \mathrm{wR}_{2}=0.1357$ \\
\hline Final $\mathrm{R}$ indexes [all data] & $\mathrm{R}_{1}=0.0570, \mathrm{wR}_{2}=0.1436$ \\
\hline Largest diff. peak/hole / e $\AA^{-3}$ & $0.65 /-0.51$ \\
\hline
\end{tabular}




\subsection{References}

[1] O. V. Dolomanov, L. J. Bourhis, R. J. Gildea, J. A. K. Howard and H. Puschmann, J. Appl. Crystallogr. 2009, 42, 339-341.

[2] G. M. Sheldrick, Acta Crystallogr. Sect. A 2008, 64, 112-122.

[3] A. Nutton, P. M. Bailey and P. M. Maitlis, Dalton Trans. 1981, 1997-2002.

[4] J. Bouffard, B. K. Keitz, R. Tonner, G. Guisado-Barrios, G. Frenking, R. H. Grubbs and G. Bertrand, Organometallics 2011, 30, 2617-2627.

[5] J. L. Herde, J. C. Lambert and C. V. Senoff, Inorg. Synth. 1974, 14, 18-20.

[6] R. Uson, A. Laguna, M. Laguna, D. A. Briggs, H. H. Murray and J. P. Fackler, Inorg. Synth. 1989, 26, 85-91.

[7] A. M. Butterfield, B. Gilomen and J. S. Siegel, Org. Process Res. Dev. 2012, 16, 664-676.

[8] a) M. J. Pouy, S. A. Delp, J. Uddin, V. M. Ramdeen, N. A. Cochrane, G. C. Fortman, T. B. Gunnoe, T. R. Cundari, M. Sabat and W. H. Myers, Acs Catalysis 2012, 2, 2182-2193; b) S. Ibanez-Maella, M. Poyatos and E. Peris, Chem. Commun. 2017; c) M. Katari, M. N. Rao, G. Rajaraman and P. Ghosh, Inorg. Chem. 2012, 51, 5593-5604; d) L. Canovese, F. Visentin, C. Levi and C. Santo, Inorg. Chim. Acta 2012, 391, 141-149; e) E. Alvarado, A. C. Badaj, T. G. Larocque and G. G. Lavoie, Chem. Eur. J. 2012, 18, 12112-12121; f) S. Gaillard, J. Bosson, R. S. Ramon, P. Nun, A. M. Z. Slawin and S. P. Nolan, Chem. Eur. J. 2010, 16, 13729-13740; g) S. Gonell, M. Poyatos and E. Peris, Angew. Chem. Int. Ed. 2013, 52, 7009-7013.

[9] a) A. S. K. Hashmi, M. C. Blanco, E. Kurpejovic, W. Frey and J. W. Bats, $A d v$. Synth. Catal. 2006, 348, 709-713; b) N. Huguet, D. Leboeuf and A. M. Echavarren, Chem. Eur. J. 2013, 19, 6581-6585.

[10] M. J. Frisch, G. W. Trucks, H. B. Schlegel, G. E. Scuseria, M. A. Robb, J. R. Cheeseman, G. Scalmani, V. Barone, B. Mennucci, G. A. Petersson, H. Nakatsuji, M. Caricato, X. Li, H. P. Hratchian, A. F. Izmaylov, J. Bloino, G. Zheng, J. L. Sonnenberg, M. Hada, M. Ehara, K. Toyota, R. Fukuda, J. Hasegawa, M. Ishida, T. Nakajima, Y. Honda, O. Kitao, H. Nakai, T. Vreven, J. A. Montgomery Jr., J. E. Peralta, F. Ogliaro, M. Bearpark, J. J. Heyd, E. Brothers, K. N. Kudin, V. N. Staroverov, R. Kobayashi, J. Normand, K. Raghavachari, A. Rendell, J. C. Burant, S. S. Iyengar, J. Tomasi, M. Cossi, N. Rega, J. M. Millam, M. Klene, J. E. 
Knox, J. B. Cross, V. Bakken, C. Adamo, J. Jaramillo, R. Gomperts, R. E. Stratmann, O. Yazyev, A. J. Austin, R. Cammi, C. Pomelli, J. W. Ochterski, R. L. Martin, K. Morokuma, V. G. Zakrzewski, G. A. Voth, P. Salvador, J. J. Dannenberg, S. Dapprich, A. D. Daniels, Ö. Farkas, J. B. Foresman, J. V. Ortiz, J. Cioslowski and D. J. Fox, Gaussian 09, Revision, Gaussian, Inc., Wallinford, CT, 2009, p.

[11] Y. Zhao and D. G. Truhlar, J. Chem. Phys. 2006, 125, 194101-194118.

[12] A. Schafer, C. Huber and R. Ahlrichs, J. Chem. Phys. 1994, 100, 5829-5835.

[13] A. V. Marenich, C. J. Cramer and D. G. Truhlar, J. Phys. Chem. B 2009, 113, 6378-6396.

[14] a) R. L. Martin, P. J. Hay and L. R. Pratt, J. Phys. Chem. A 1998, 102, 3565-3573;

b) N. Sieffert and M. Buhl, Inorg. Chem. 2009, 48, 4622-4624.

[15] S. Grimme, S. Ehrlich and L. Goerigk, J. Comput. Chem. 2011, 32, 1456-1465.

[16] S. Grimme, J. Comput. Chem. 2006, 27, 1787-1799.

[17] J. D. Chai and M. Head-Gordon, Phys. Chem. Chem. Phys. 2008, 10, 6615-6620.

[18] S. Grimme, J. Antony, S. Ehrlich and H. Krieg, J. Chem. Phys. 2010, 132, 154104.

[19] a) F. Weigend and R. Ahlrichs, Phys. Chem. Chem. Phys. 2005, 7, 3297-3305; b)

F. Weigend, Phys. Chem. Chem. Phys. 2006, 8, 1057-1065.

[20] R. C. Clark and J. S. Reid, Acta Crystallogr. Sect. A 1995, 51, 887-897. 

